\title{
علاقة المقاصد بالأدلة والقواعد الفقمية
}

مكثنورة/ خبرلية بنت محهم المباهص

أستاذ مساعد بقسم أصول الفقهـ كلية الثريعة

جامعة الإمام محمد بن سعود الإسلامية بلمية

\section{مُقَََمَة}

إن الحمد لله، نحمده ونستعينه، ونستغفره، ونستهديه، ونعوذ بــالله مــن شـرور هفر

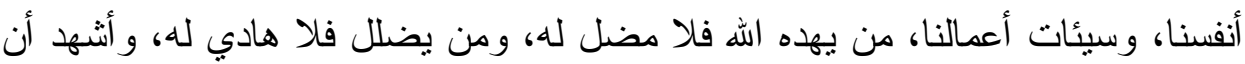

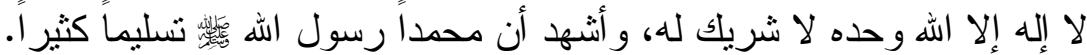
أما بعد:

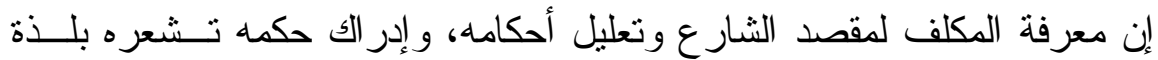

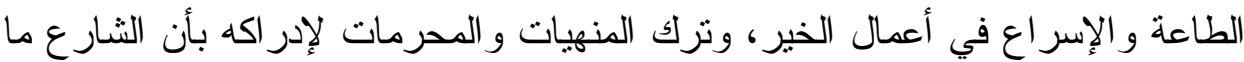

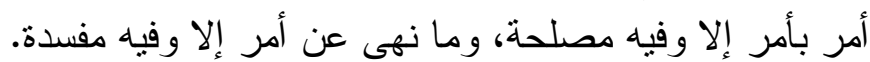

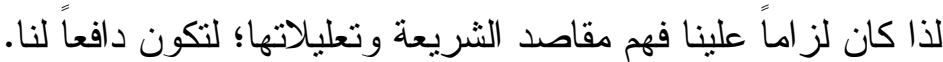
وتبرز أهمية الموضو عان في النقاط الآتية:

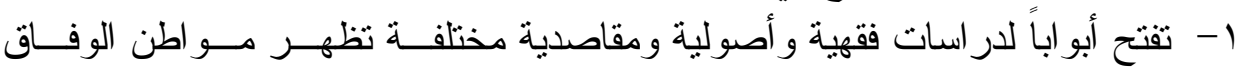
و الخلاف بين العلماء.

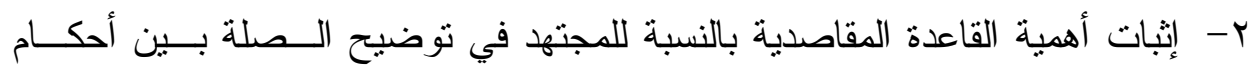

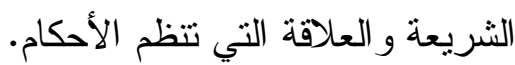
r- يظهر التآلف بين الأدلة والمقاصد، مما له أثز بالغ في التوصل إلى مقام مقاصد حقيقية

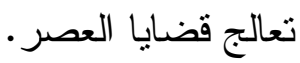

وقد سرت في هذا البحث على الخطة التالية: مقدمة وتمهيد ومبحثني:

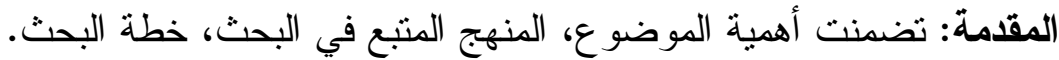
التمهيد: في التعريف بالمصطلحات الواردة في البحث، وفيه ثلاثة مطالب:

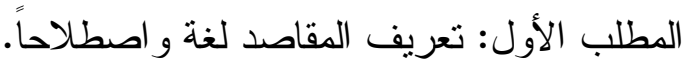
المطلب الثاني: تعريف الأدلة لغة و اصطلاحاً. المطلب الثالث: تعريف القو اعد الفقية لغة ولف واصطة الفطلاحاً. 
المبحث الأول: علاقة المقصد بالأدلة، ويتضمن مطلبين:

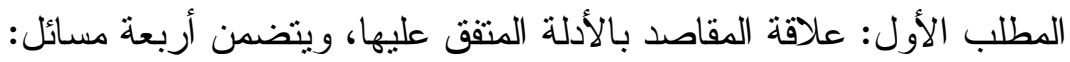

المسألة الأولى: علاقة المقاصد بالكتاب.

المسألة الثانية: علاقة المقاصد بالسنة.

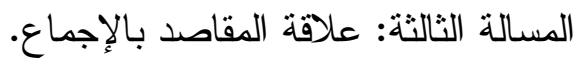

المسألة الر ابعة: علاقة المقاصد بالقياس.

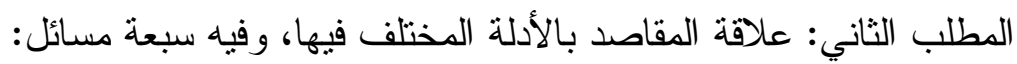

المسألة الأولى: علاقة المقاصد بالمة المصلحة المرسلة.

المسألة الثانية: علاقة المقاصد بالاستحسان.

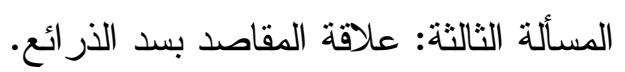

المسألة الر ابعة: علاقة المقاصد بقول الصحابي.

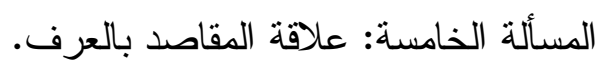

المسألة السادسة: علاقة المقاصد بشر ع من قبلنا.

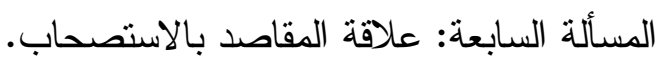

المبحث الثاني: علاقة المقاصد بالقواعد الفقهية، ويتضمن خمسة مطالب:

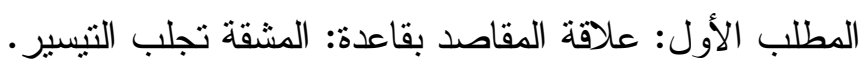

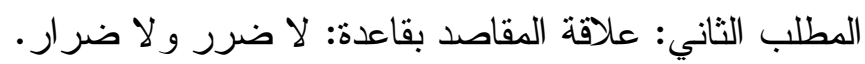

المطلب الثالث: علاقة المقاصد بقاعدة: العادة محكمة.

المطلب الر ابع: علاقة المقاصد بقاعدة: اليقين لا يزول بالثة الثقاه.

المطلب الخامس: علاقة المقاصد بقاعدة: الأمور بمقاصدها.

$$
\text { منهج البحث: }
$$

1- الاستقر اء التام لمصادر المسألة، ومر اجعها المتقدمة و المتأخرة.

ץ- الاعتماد عند الكتابة على المصادر الأصلية في كل مسألة بحسبها.

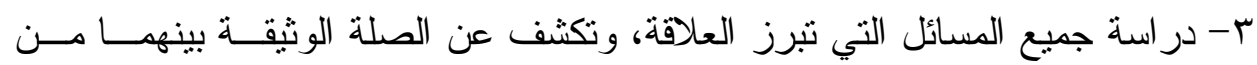

$$
\text { الجانب التأصيلي. }
$$

ع - التمهيد للمسألة بما يوضحها إن إن احتاج المقام لذلك.

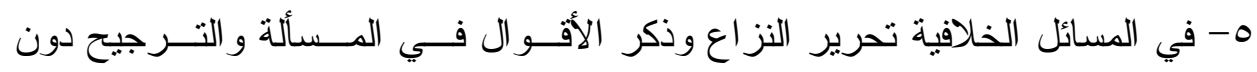
استطر اد في أدلة الأقو ال. 


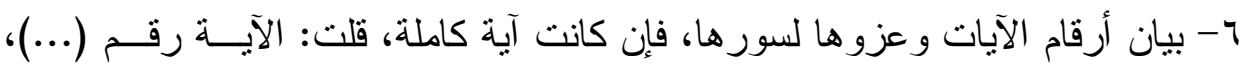

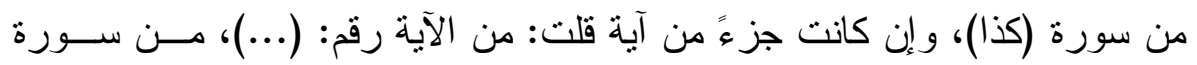

- أتبع في تخريج الأحاديث و الآثار المنهج الآتي:

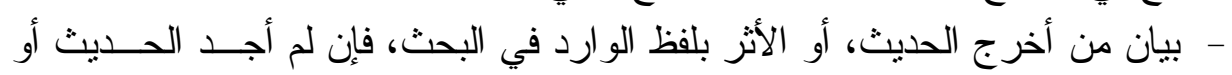

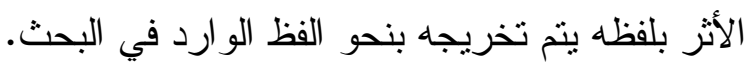

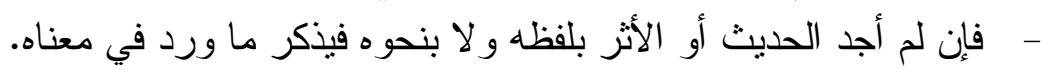

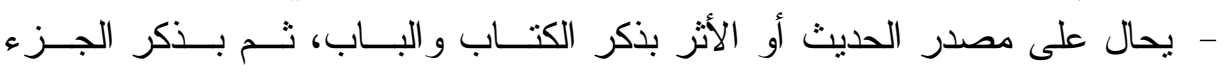

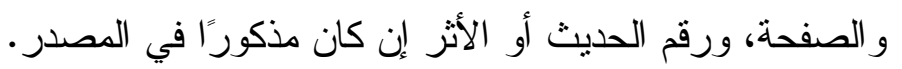




\section{التمهيد}

\section{في التعريف بالمصطلحات الواردة في البحث}

وفيه ثلاثة مطالب:

المطلب الأول: تعريف المقاصد الشرعية لغة واصطلاحاً

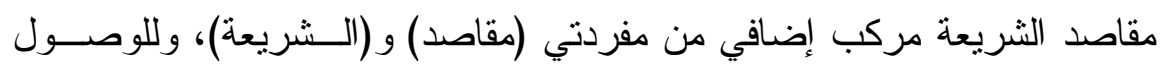
إلى معنى مصطلح (مقاصد الثريعة) لابد من تعريف كل منهما على حدة.

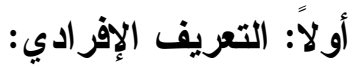

تعريف المقاصد:

لغة: جمع مقصد و المقصد؛ مصدر ميمي مشتق من الفعل قصد، يقال: قـــدته

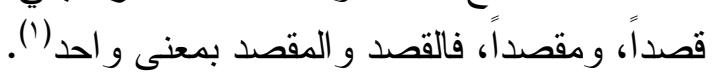

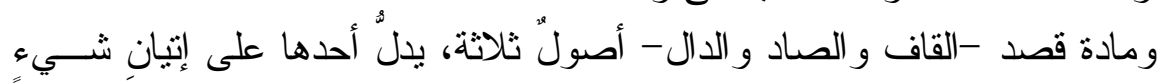

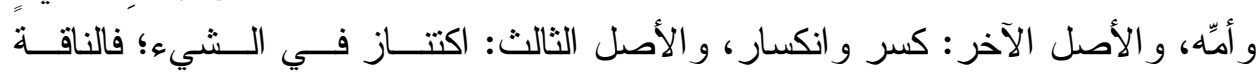
القصبد: المكتنزة الممتلئة لحماً (ب).

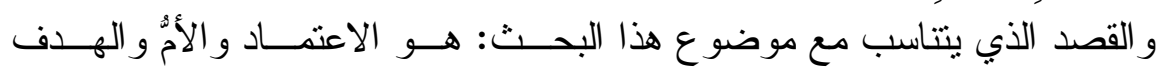
و الغاية المر اد الوصول إليهاب(ّ).

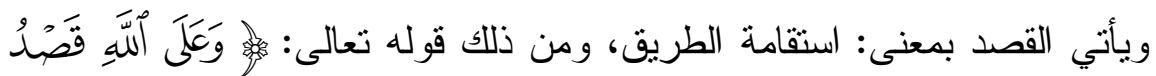

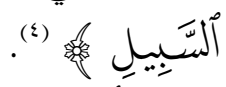

أي: على الله بيان طريق الحكم، و القصد من الطريق: المستقيم الذي لا اعوجـــاج فيه (0).

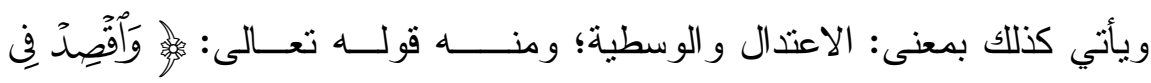


أي: "توسيط فيه، و القصد ما بين الإسر اعو البطء، أي: لا تدب دبيب المتــاوتين

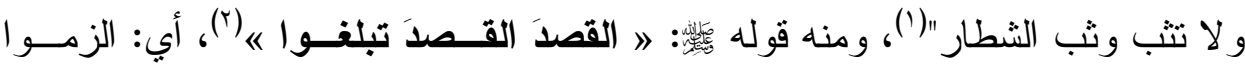

الطريق الوسط المعتدل("). تعريف الشريعة:

لغة:

مصدر شَرَعَ يشر ع على وزن منع، وتطلق في اللغة على عدة معانٍ، منها (َ):

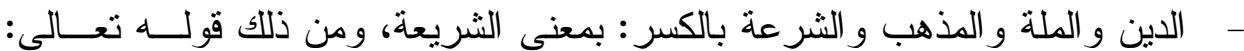

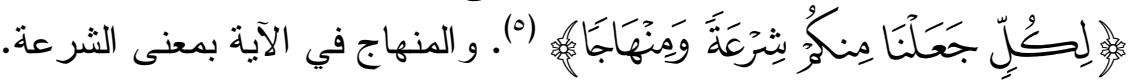
- ابتداء الثَيء: يقال: شرع فلان في كذا، أي: ابتدأ فيه.

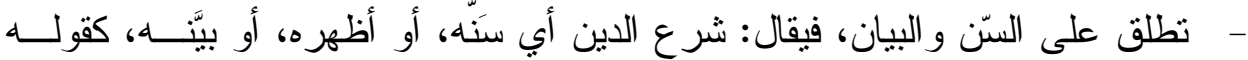

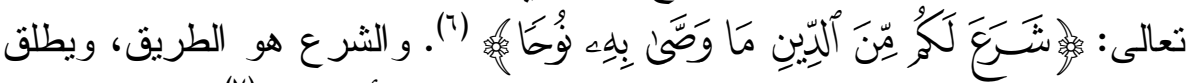

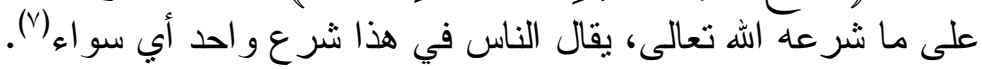

تعريفها اصطلاحاً:

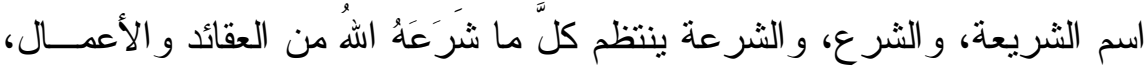

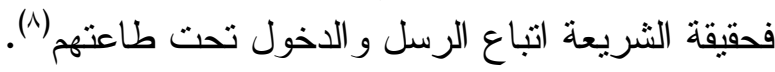

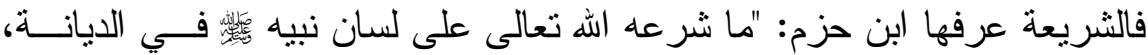

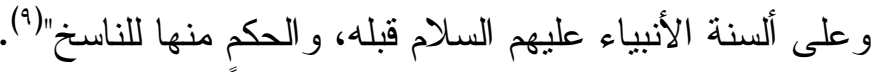
ب - تعريف المقاصد الثرعية باعتبار ها لقباً:

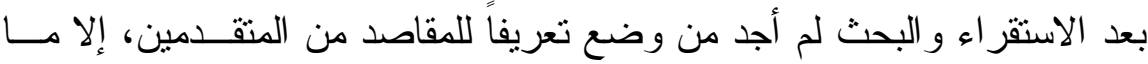

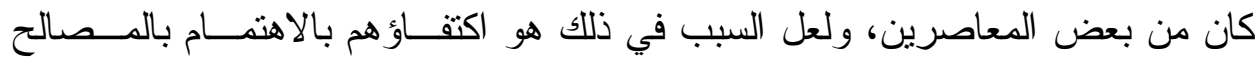

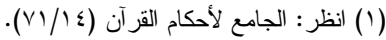

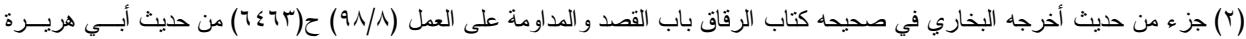

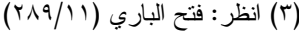

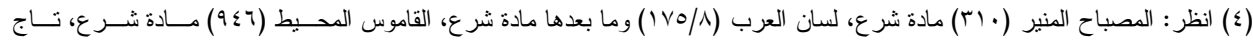

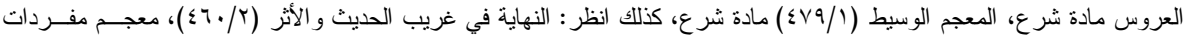

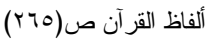
(0) جزءء من الآية (1) من سورة المائدة.

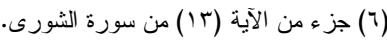

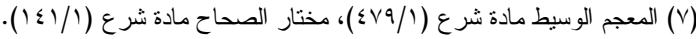

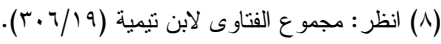

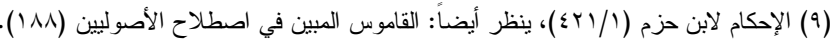


وبتقسيماتها، وبالمناسب و أقسامه عن تعريف المقاصد لاستو اء الأمسـرين عنــدهم، و لأن

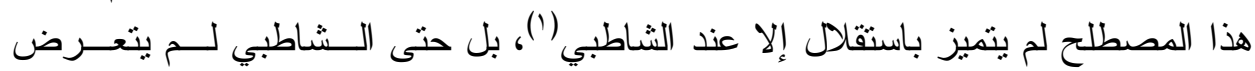

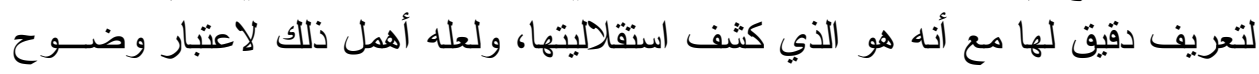

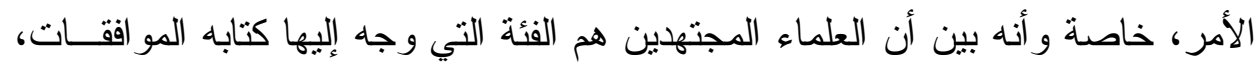

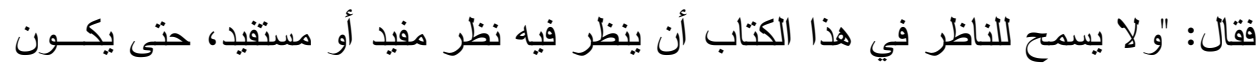

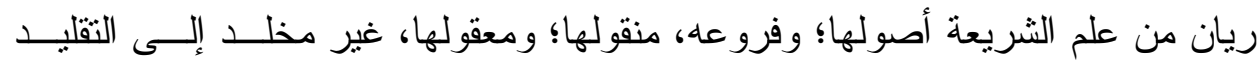

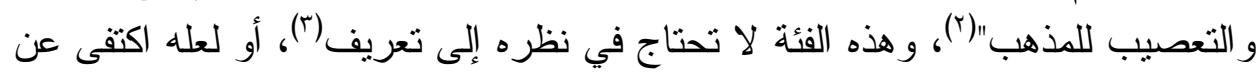

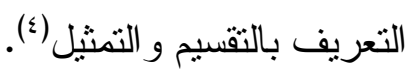

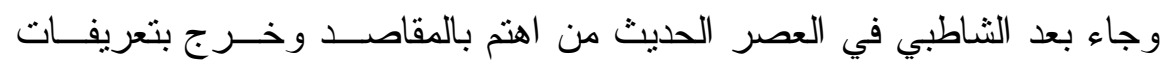

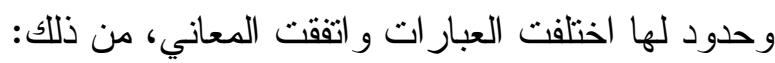

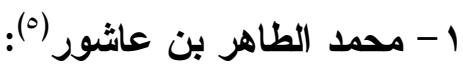

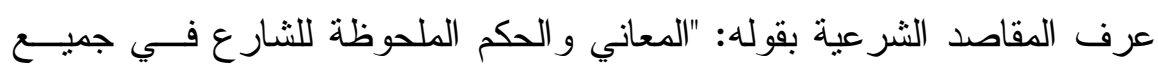

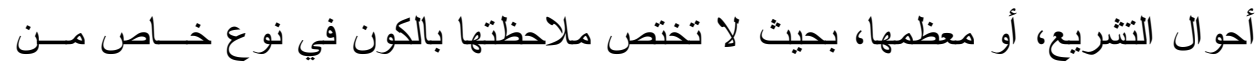

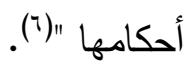

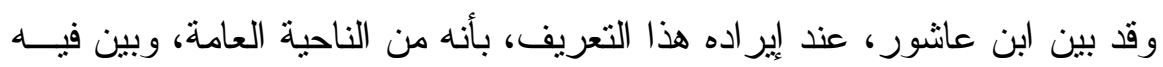

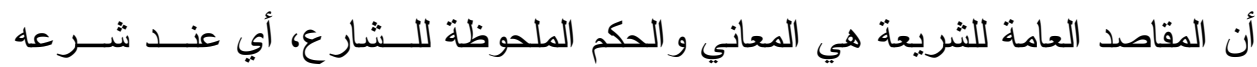

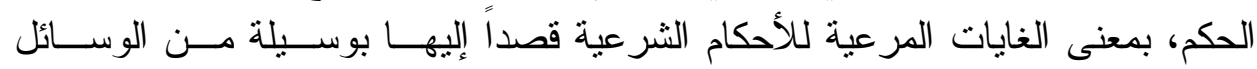

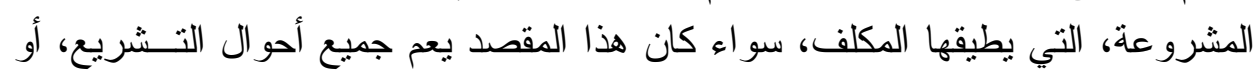
معظمها.

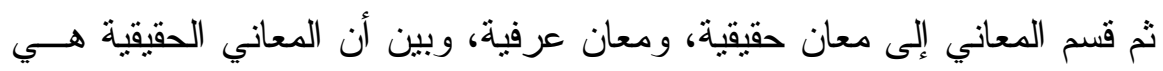

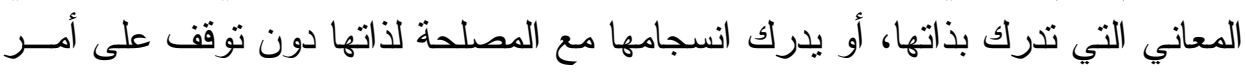

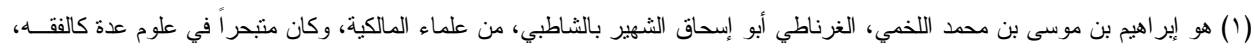

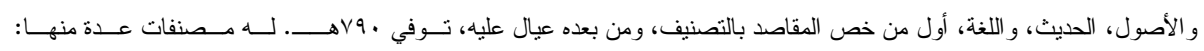

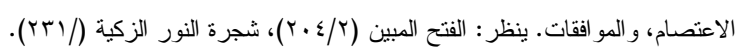

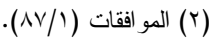

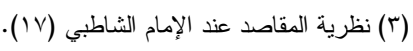

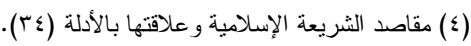

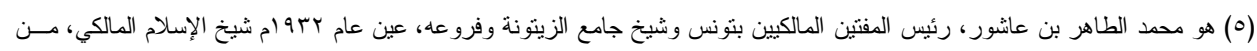

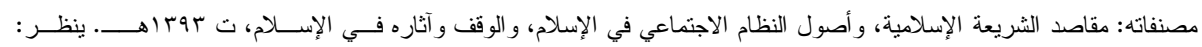


خارجي"، كإدر الك كون العدل نافعاً، وكون الاعتداء على النفوس ضار أ، وكون الأخــذ

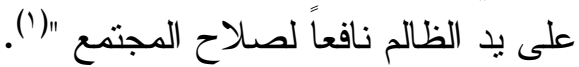

ومما يؤخذ على هذا التعريف تعبيره عن المقاصد بالمعاني، و المعاني في الحقيقة

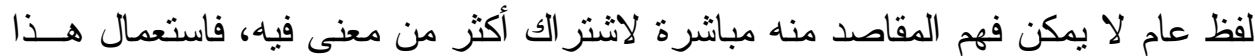

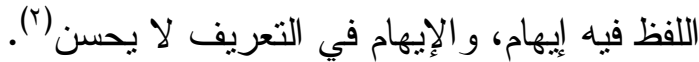

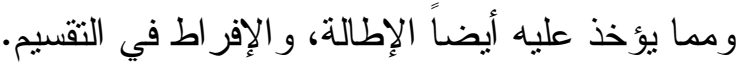

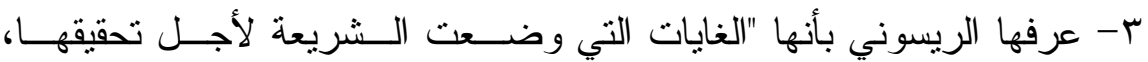

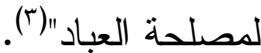

ع - عرفت مقاصد الثريعة بأنها "المعاني و الأهداف الملحوظة في جمع أحكامسـه

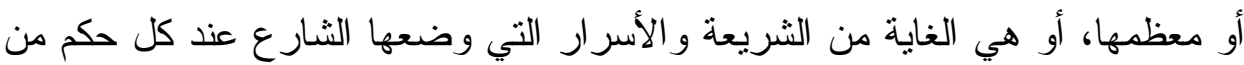

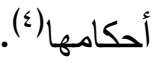
ه- عرفت مقاصد الثريعة بأنها "المعاني و الحكم ونحو ها التي ر اعهــا الـششارع في التشريع عموماً، وخصوصاً من أجل تحقيق مصالح العباد"(ه). المطلب الثاني: تعريف الأدلة لغة و اصطلاحاً تعريف الاليل لغة: قال ابن فارس: "أصلان: أحدهما: إبانة الثيء بأمارة تتعلمها، و الآخر اضطر اب في الثيء" (ج).

و الدليل: مأخوذ من دلّ يدل دلالة، وقد دل على الطريق يدلــهـ دلالـــة، ودلالــــة

ودلولة، و الفتح أعلى (v). ودله على الثيء يدلّه دلاً ودلالة فاندلّ، ودللته فاندل. 


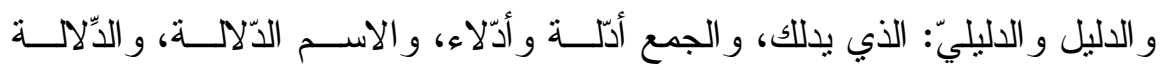

$$
\text { و الدلولة و الدليليّ('). }
$$

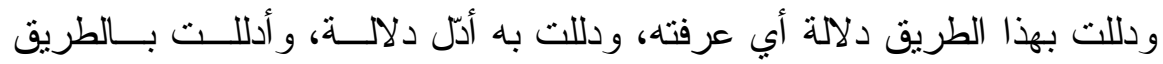

(r) إدلالاً

و الدليل فعيل بمعنى فاعل بمعنى الدال و المرشد إلى المقصود، وفعله دل: بمعنى

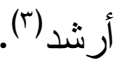

وقد ذكر أكثر الأصوليين( أن الدليل له في اللغة ثلاث معان:

الأول: المرشد إلى المقصود.

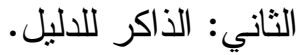

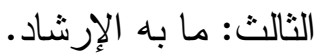

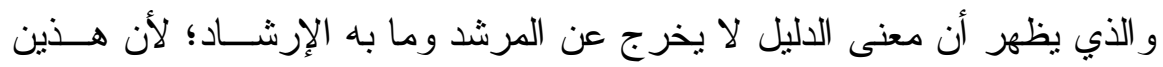

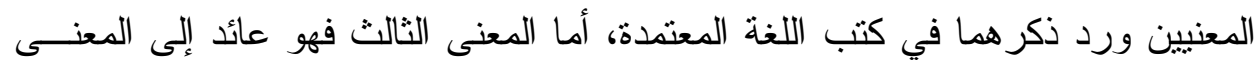

ثم إن المعنى الأول وهو المرشد يمكن أن يشمل جميع ما ذكر ويدخل في معنــاه

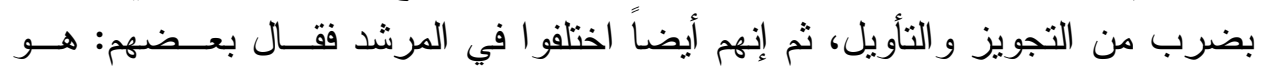

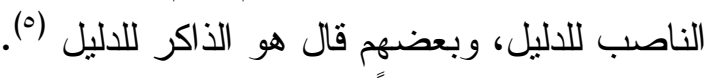
تعريف الاليل اصطلاحاً:

لقد سلك الأصوليون اتجاهين رئيسين لهم في تعريف الاليل:

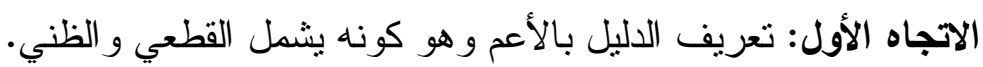
الاتجاه الثاني: تعريف الاليل بالأخص وهو وهو كونه يشمل القطعي فقط.

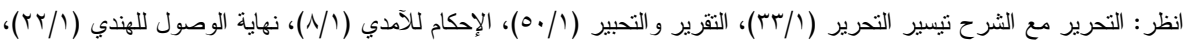

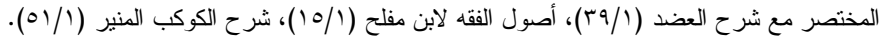

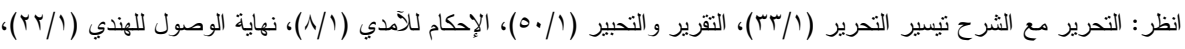

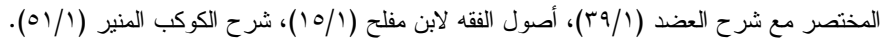

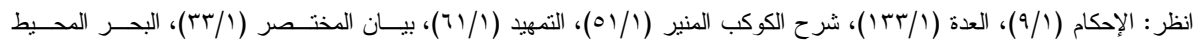

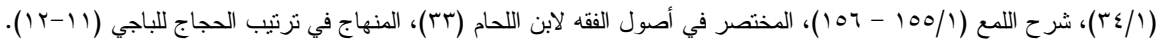


وقد سلك الاتجاه الأول أكثر الأصوليين منهم الباقلاني(')، والقاضي أبو يعلى()، ()،

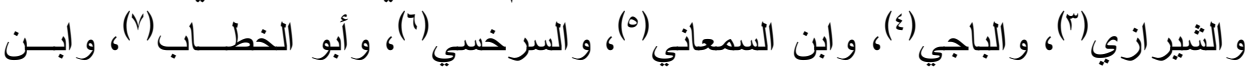

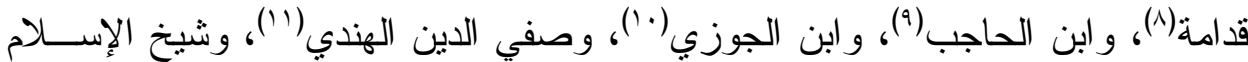

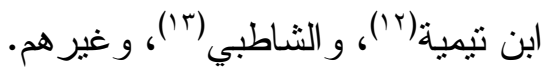
ومن تعريفاتهم الآتي:

عرفه ابن قدامة: "ما ينوصل بصحيح النظر فيه إلى علم أو ظن"(1)

$$
\begin{aligned}
& \text { التقريب و الإرشاد (Y/Y.r). } \\
& \text { العدة (1/T) (1). } \\
& \text { شرح اللمع (100/1). }
\end{aligned}
$$

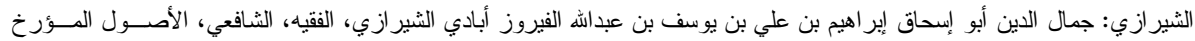

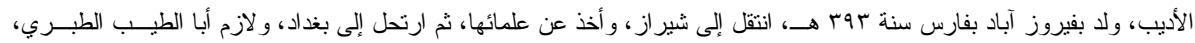

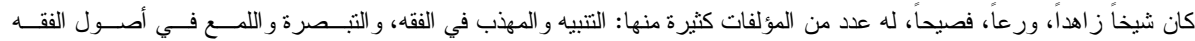

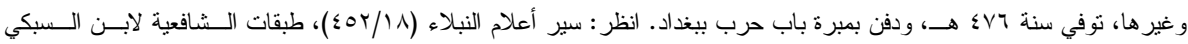

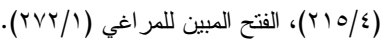

$$
\begin{aligned}
& \text { المنهاج في ترتيب الحجاج (1') (1). }
\end{aligned}
$$

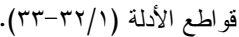

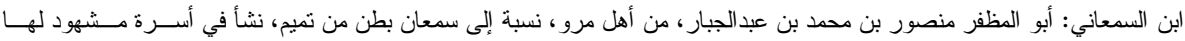

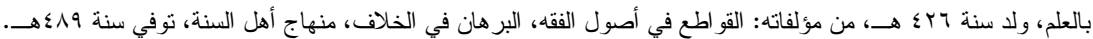

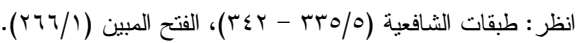

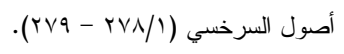

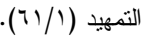

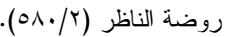

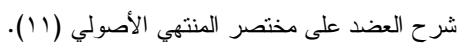

(1) (1) الإيضاح لقو انين الاصطلاح (1) (1).

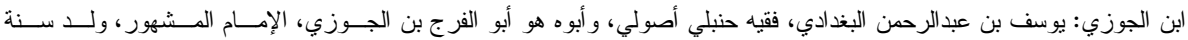
)

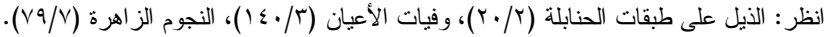

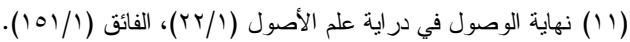

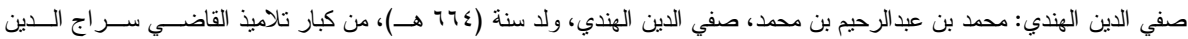

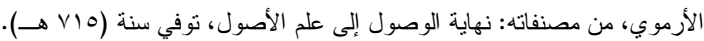

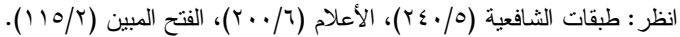

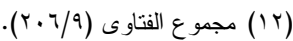

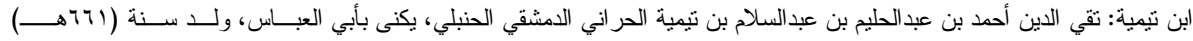

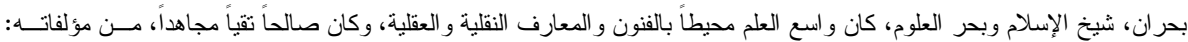

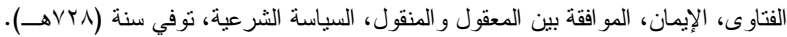

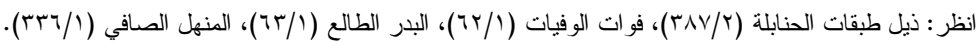




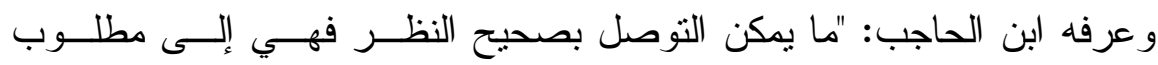

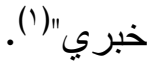

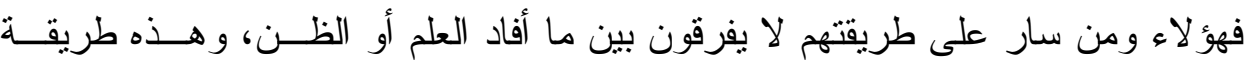
الفقهاء في تعريف الدليل.

قال الآمدي: "وهذاء هو المسمى دليلاً في عرف الفقهاء وسواء كان موصلاً إلى علم أو ظن" (ب).

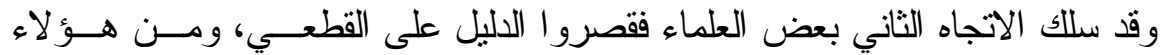

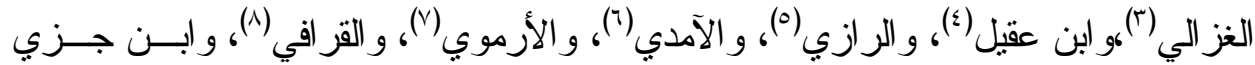

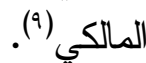
ومن تعاريفهم الآتي:

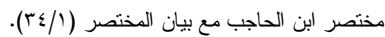

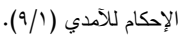

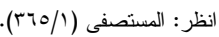

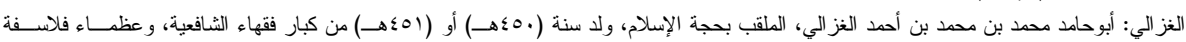

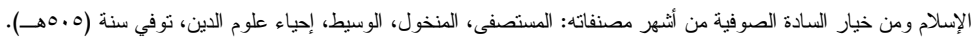

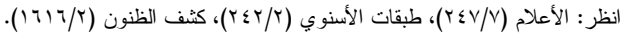

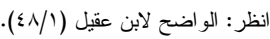

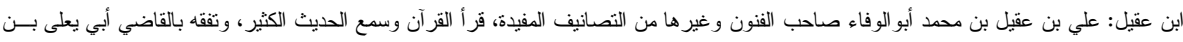

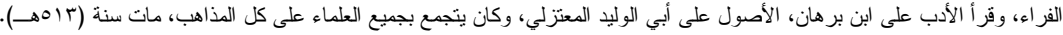

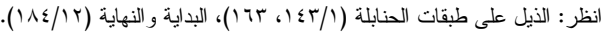

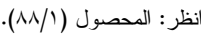

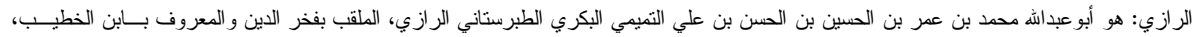

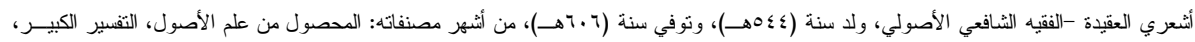
علم الكلام وغير ها.

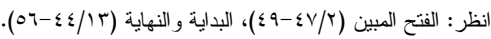

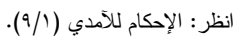

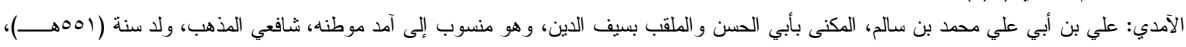

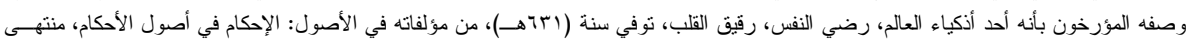
السول في علم الأصول.

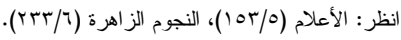

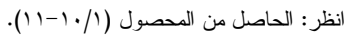

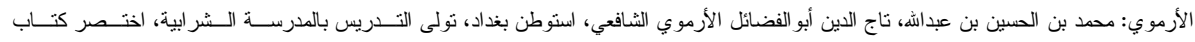

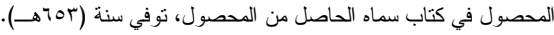

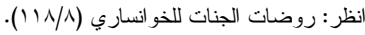

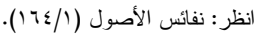

القر افي: أحمد بن إدربس، شهاب الدين، أبو العباس الصنهاجي، المالكي، كان إمامًا بار عاً في الفقه و الأصول و العلوم العقلية، من مصنفاته: الذخيرة في الفقه، شرح لمحصول،

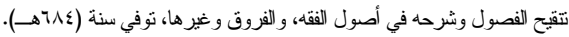

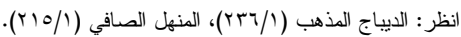

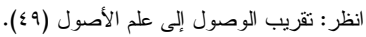

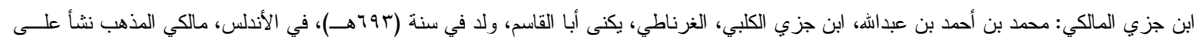

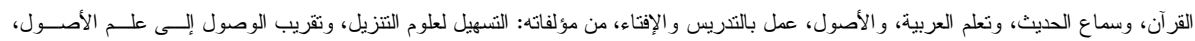

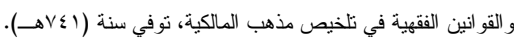

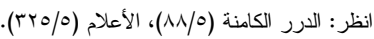


عرفه الغز الي: "الموصل بصحيح النظر فيه إلى العلم بما هو دليل عليه"(').

و الر ازي: "الدليل فهو الذي يمكن أن يتوصل صحيح النظر فيه إلى العلم" (؟).

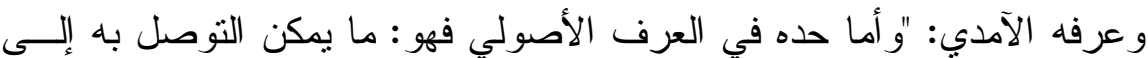

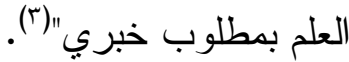

ولعل الاتجاه الأول هو الأولى؛ لأنه قول أكثر أهل الأصول، ومــن تتبـــع أدلـــة

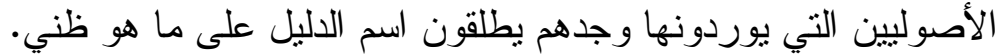

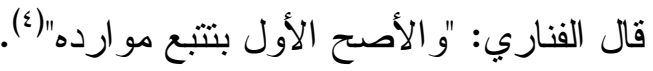

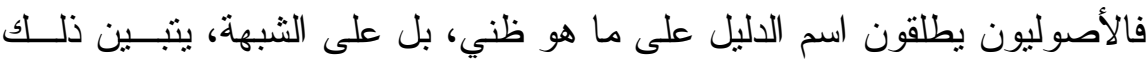

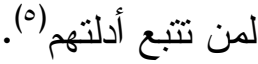
المطلب الثالث: تعريف القواعد الققهية لغة واصطلاحاً

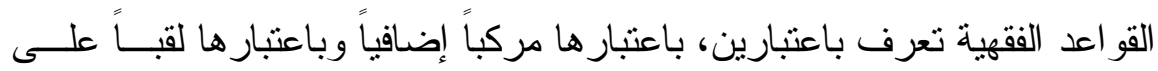

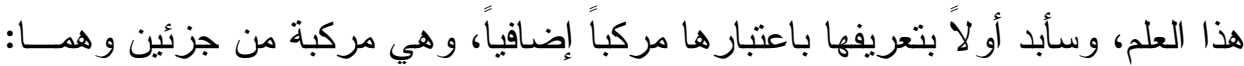

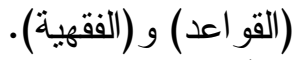
أولاً: القو اعد: اعد اعد

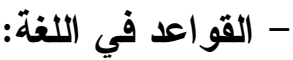

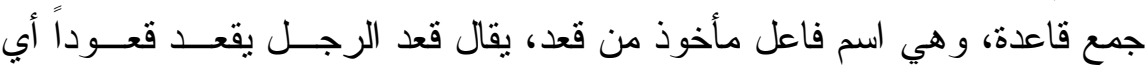

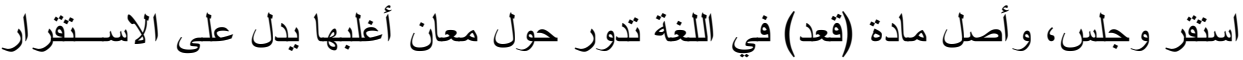

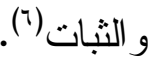

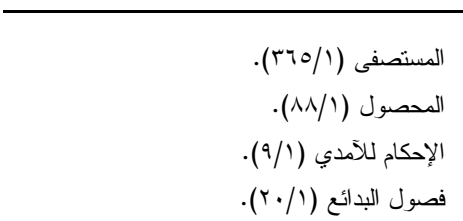

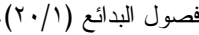

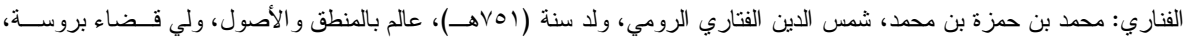

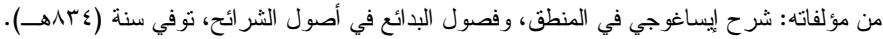

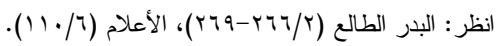

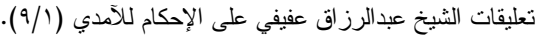

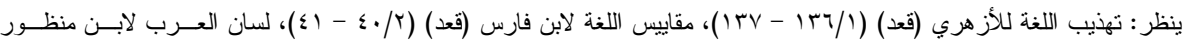

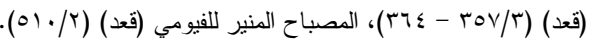




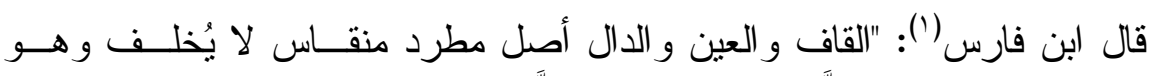

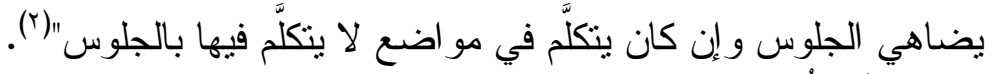

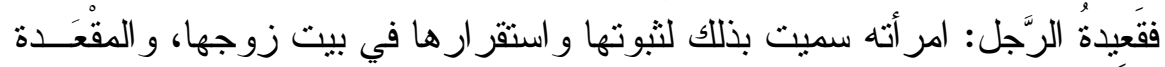

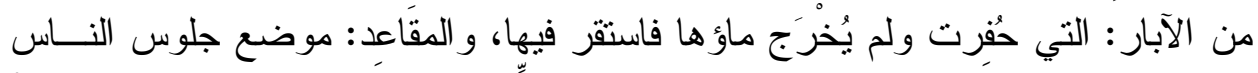

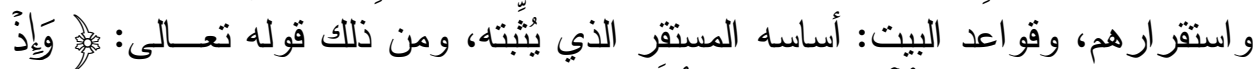

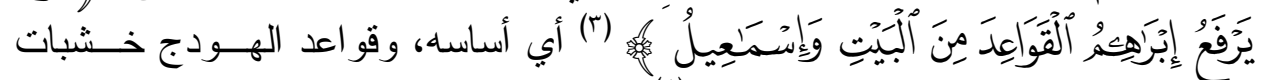

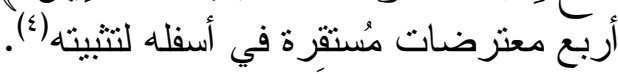

- القواعد في الاصطلاح:

عرفت القاعدة في الاصطلاح بتعريفات عدة، من أبرز أنها:

"قضية كلية منطبقة على جميع جزئياتها"(0).

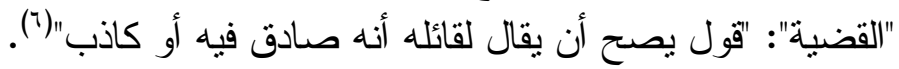

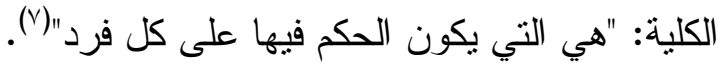

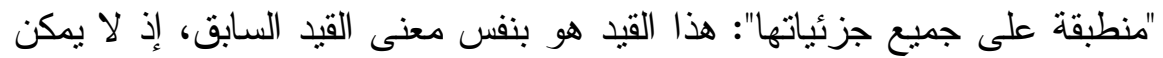

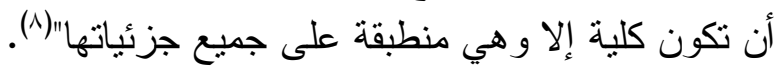
ثانياً: الفقهه: الفقه في اللغة:

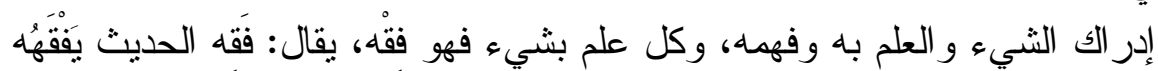

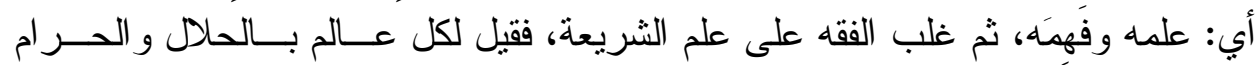

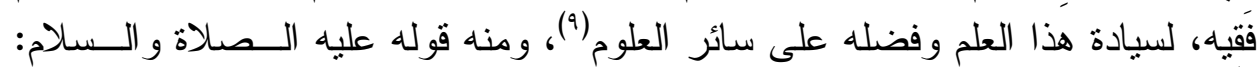

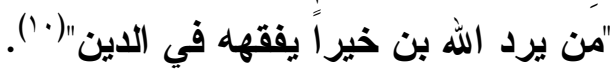

ابن فارس: أحمد بن فارس بن زكريا بن محمد أبو الحسبن الخرساني كان إماماً في اللغة و الفقه و الأدب من مؤلفاته: مقاييس اللغة، المجمـل فـــي

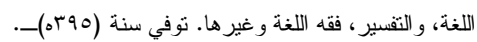

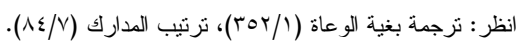

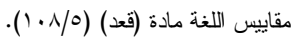
جزءء من الآية (YV ( ) من سورة البقرة.

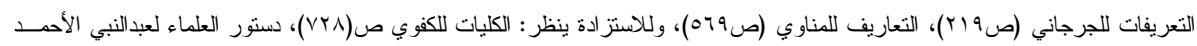

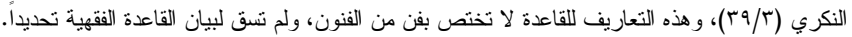

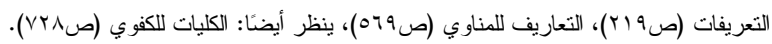
التعريفات (صTrTr). التمهيد للأسنوي (صریفاك).

ينظر : القو اعد الفقهية للاكتور يعقوب الباحسين (صنابن).

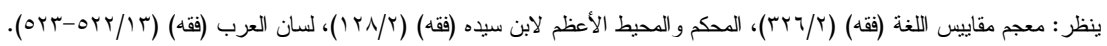

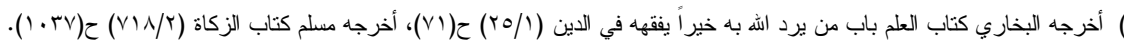


الفقه في الاصطلاح:

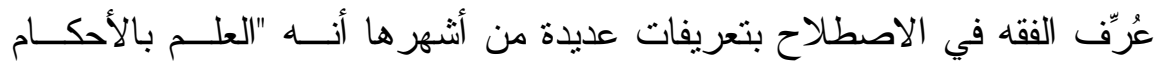

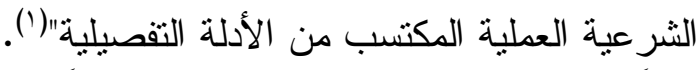
ثالثاً: المر اد بالقو اعد الفقهية باعتبارها لقباً:

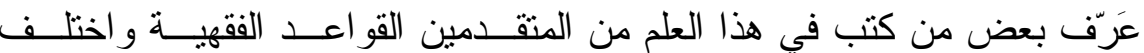

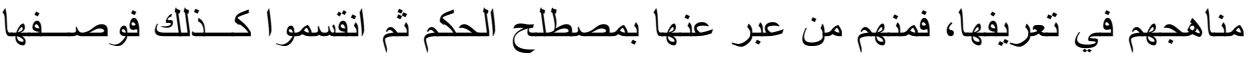

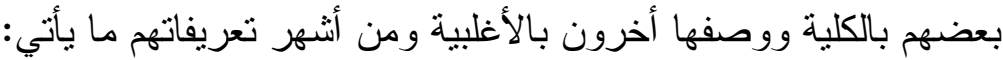

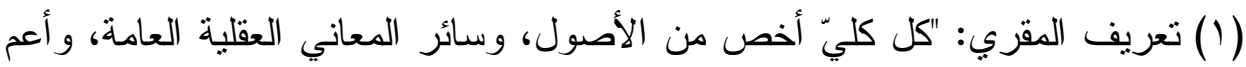

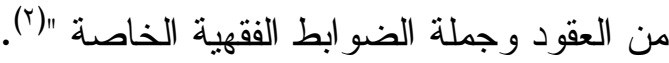

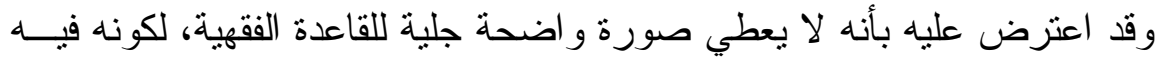

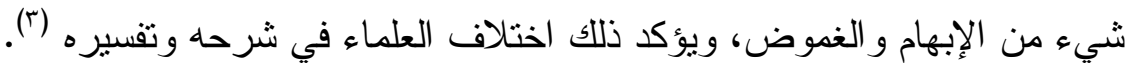

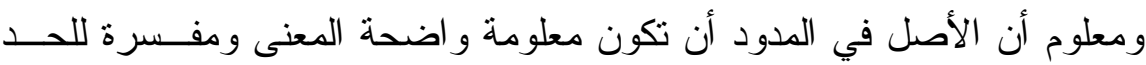
و ألا يجب أن يستبعد.

(ץ) تعريف ابن السبكي: "الأمر الكلي الذب ينطبق على جزئيات كثيرة تقهم أحكامها منها"().

وقد اعترض عليه بأن التعبير بلفظ "الأمر" أعم مــن لفــ "القـضية"، لــشموله

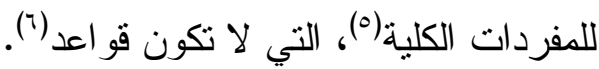

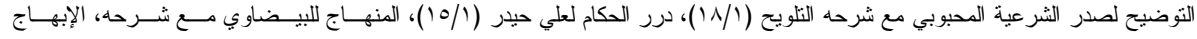

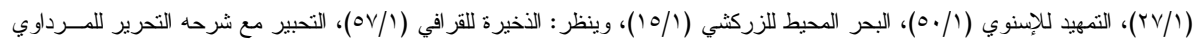

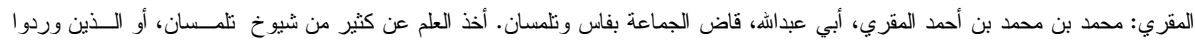

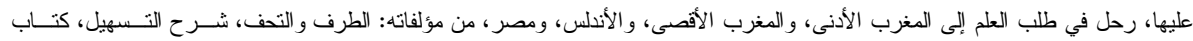

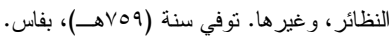

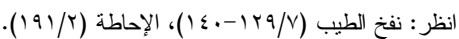

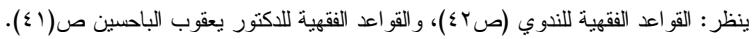

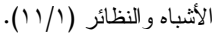

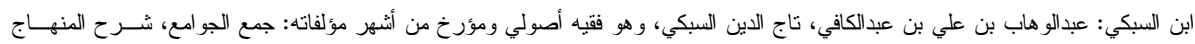

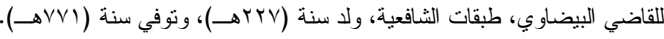

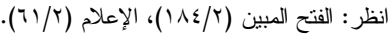

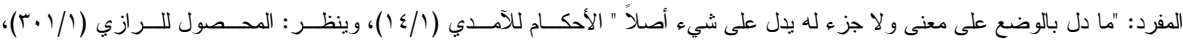

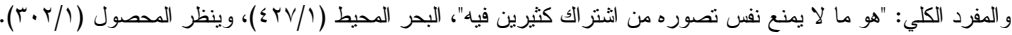

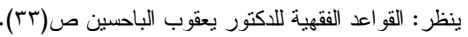




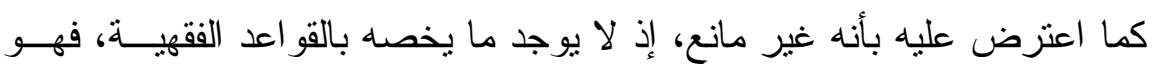

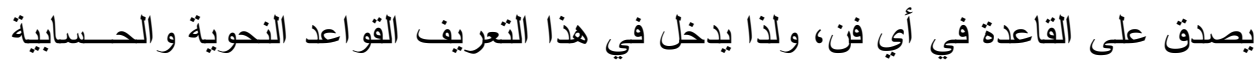

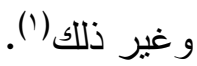

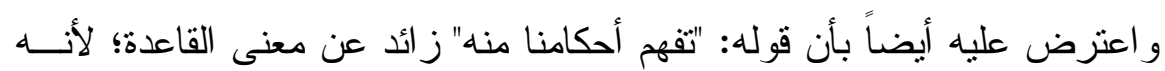

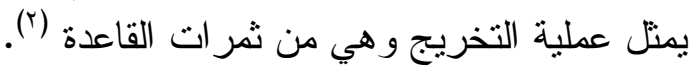

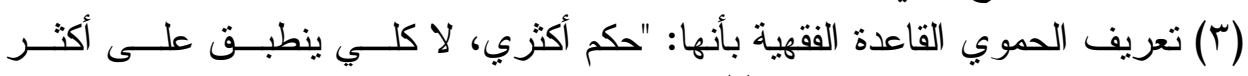

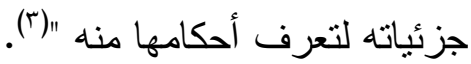

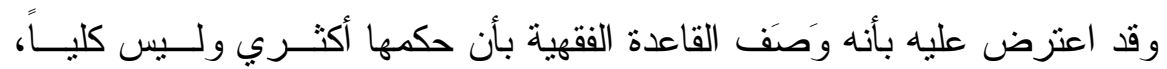

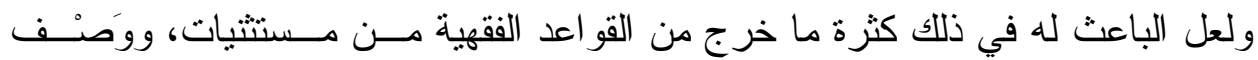
القاعدة الفقهية بالكلية أولى، وذللك لعدة أمور : ألى

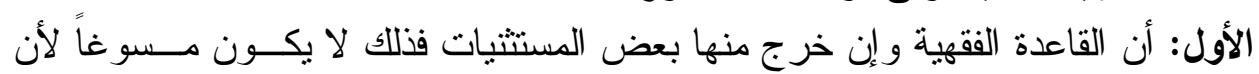
تخرج من أن توصف بالكلية.

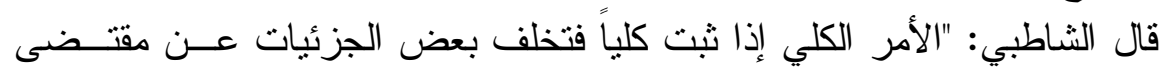

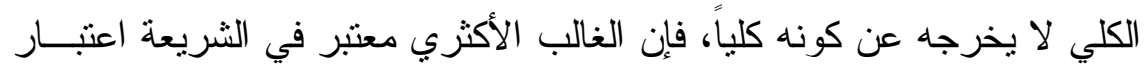

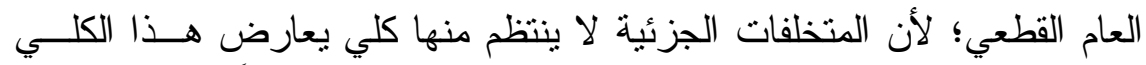

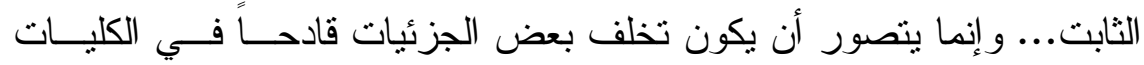

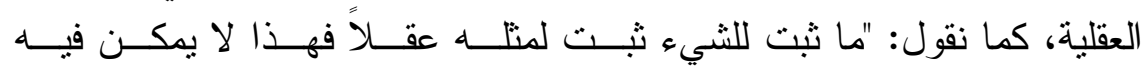

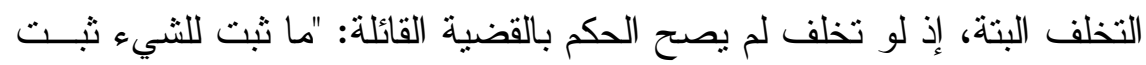

لمنتله" (乏)

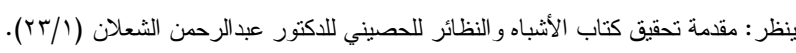

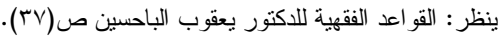

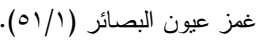

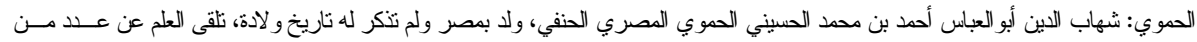

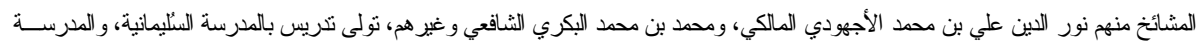

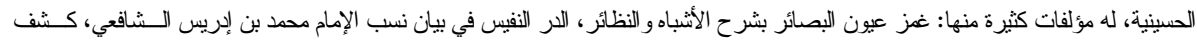

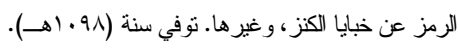

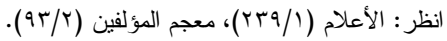

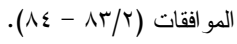

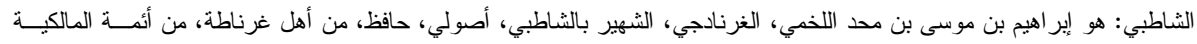

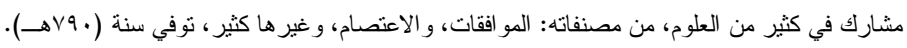

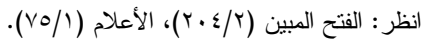


الثاني: أن القو اعد في مختلف العلوم لا نخلو من وجود مستثيات، مع اختلاف النـسبة

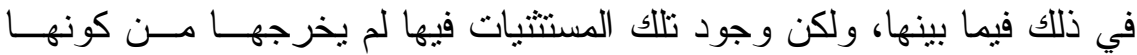
كلية) (') في

(ع) ذكر بعض المعاصرين تعريفات منها ما يأتي:

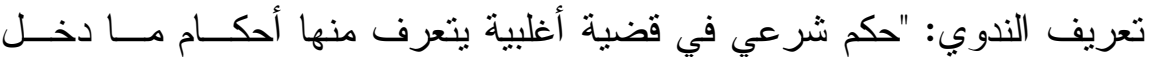

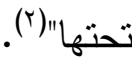
و اعترض عليه بأن فيه زيادة لا داعي لها، لكونه ذكر الحكم و القضية، وفي ذلك

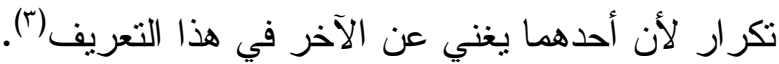

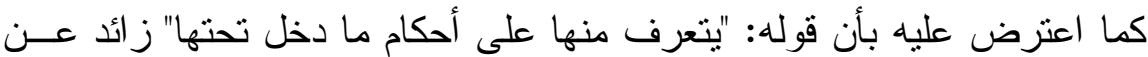

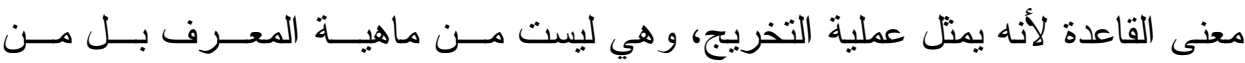

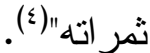

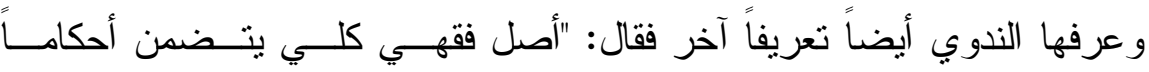

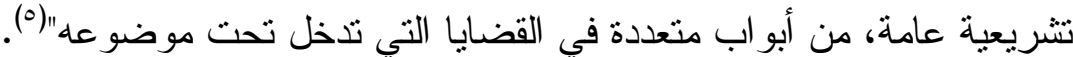

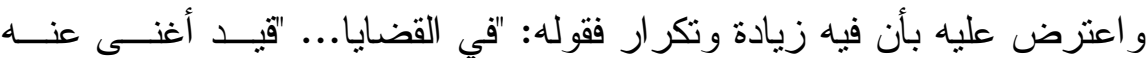

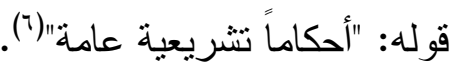
- تعريف الدكتور يعقوب الباحسين: "قضية فقهية كلية، جزئياتها قـــايا فقهيــة كلية"( (v)

يمكن أن يعترض عليه بأنه لا يوجد في هذا التعريف ما يميز بين القاعدة الفقهية

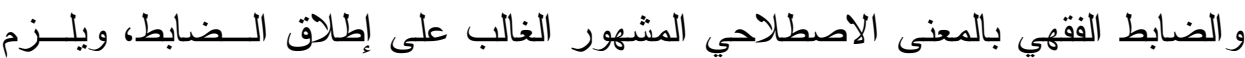
عليه الدور لورود كلمة فقهية في الطرفين المعرف و المعرف بهاهيطان.

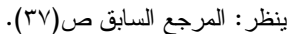

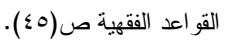

ينظر : القو اعد الفقهية للاكتور يعقوب الباحسين ص(0.0).

القو اعد الفقهية ص( ؟ م). 
تعريف الدكتور : عبدالرحمن الثعلان "حكم كلي فقهي ينطبــق علــى جزئيــات

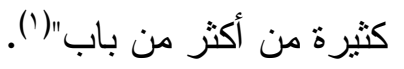

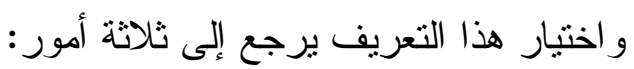

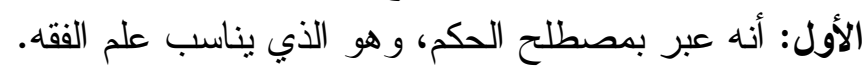

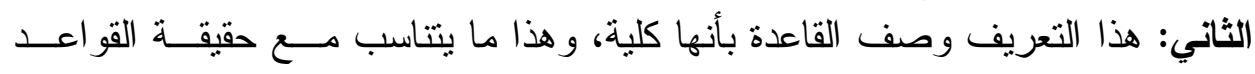

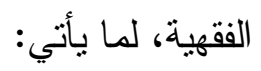

أ - أن شذوذ بعض الفروع الفقهية لا ينافي وصف القاعدة الفقهية بالكلية.

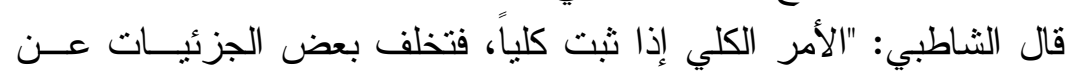

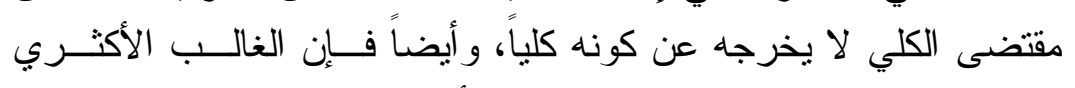

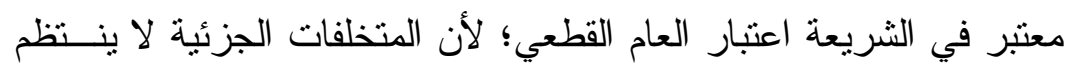
منها كلي يعارض هذا الكلي الثابت" (؟).

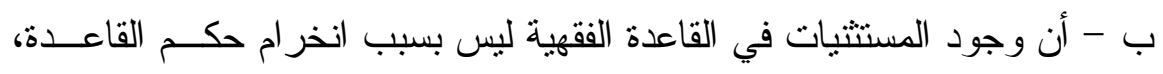

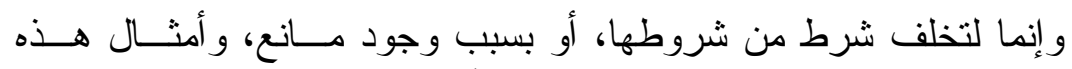

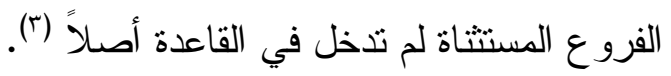

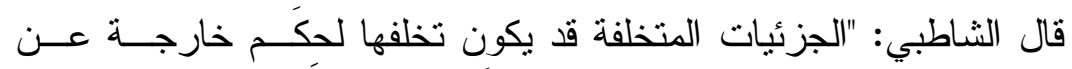

مقتضى الكلي فلا يكون داخلة تحته أصلاً "(£). الثالث: أنه قيد التعريف (بأكثر من باب) و هذا يخر الضون الضابط الفقهي. 
المبحث الأول: علاقة المقصد بالأدلة

ويتضمن مطلبين:

المطلب الأول: علاقة المقاصد بالأدلة المتفق عليها

المسألة الأولى: علاقة المقاصد بالقرآن:

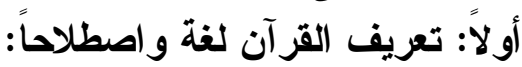

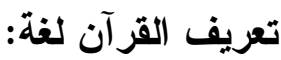

مصدر قر أ يقر أ قر اءة وقر آناً.

يقال: قر أت الكتاب قر اعة وقر آثرة آناً.

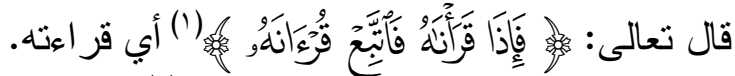

و أصل القر اءة في اللغة: الضم و الجمع (؟).

تعريف القر آن اصطلاحاً:

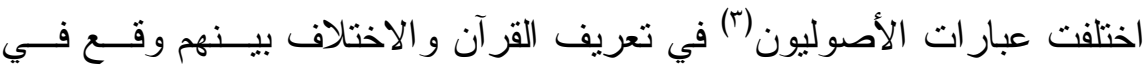

وضع قيود التعريف فقط.

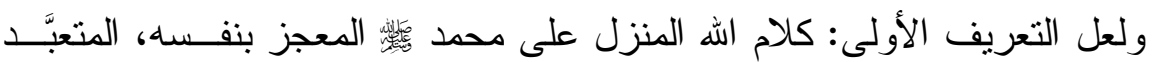

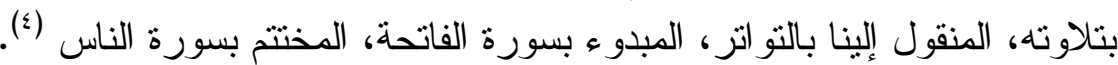

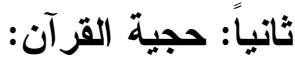

انعقد إجماع المسلمين على حجية القرآن، وممن نقل الإجماع على ذللك:

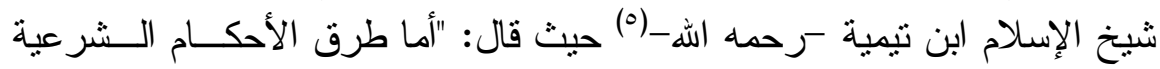

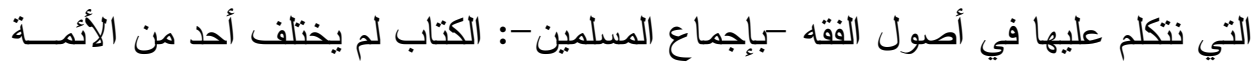

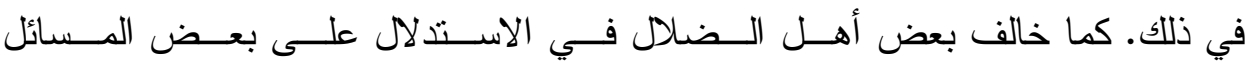

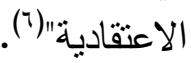

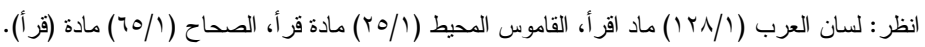

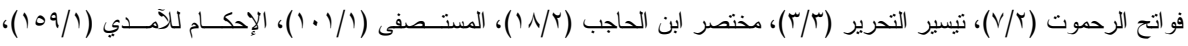

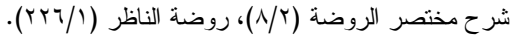

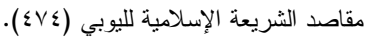

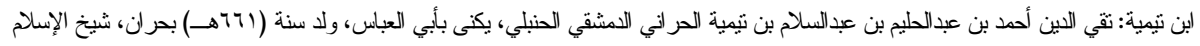

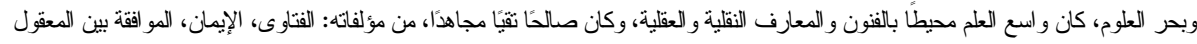

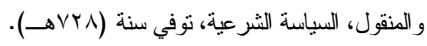

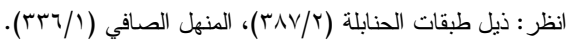

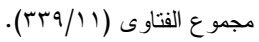


فهو يذكر أن المسلمين متفقون في الجملة علـى الاســــلال بــهـ علــى العقائـــ

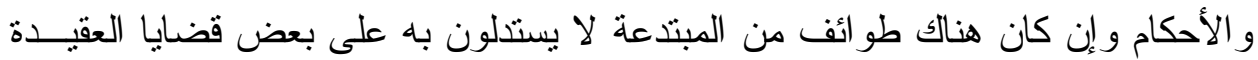
(القطعية) (1)

و أيده بذلك ابن القيم - رحمه الله -: قال: "حري بالإنسان أن بنفق ساعات عمره

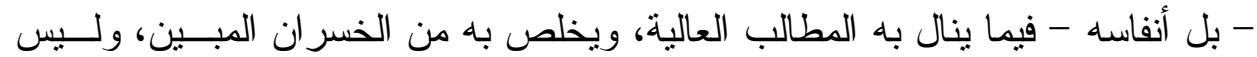

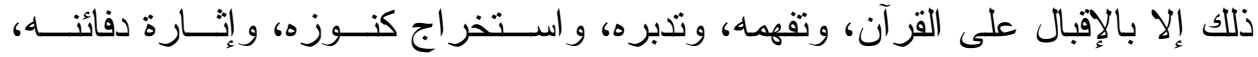

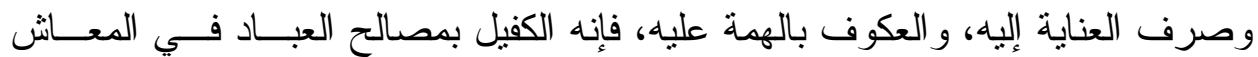

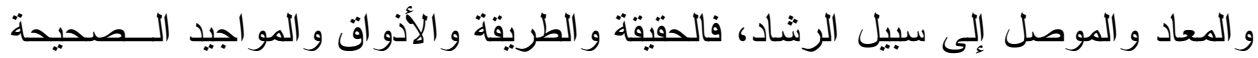

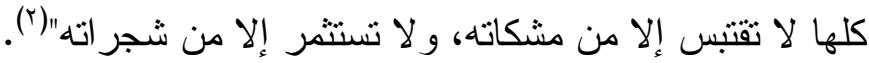

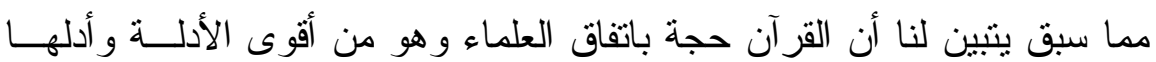

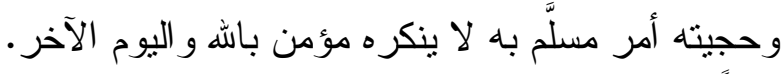

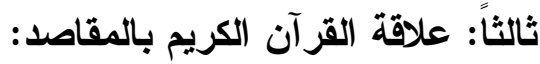

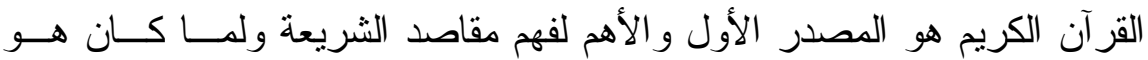

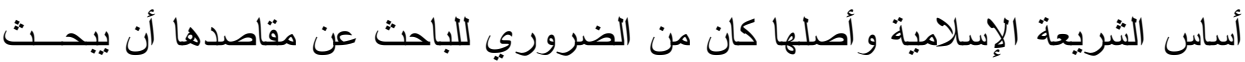

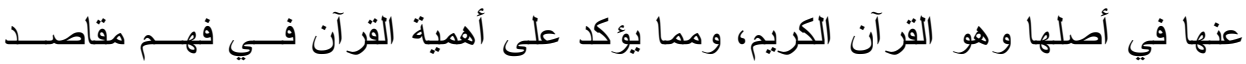
الثريعة ما نقل من نصوص العلماء في ذللك، منها:

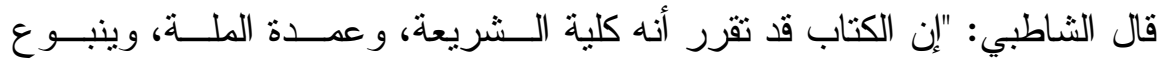

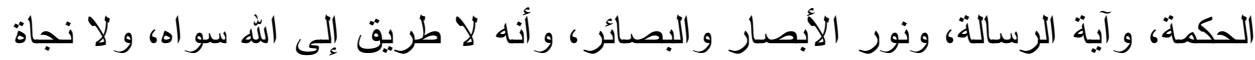

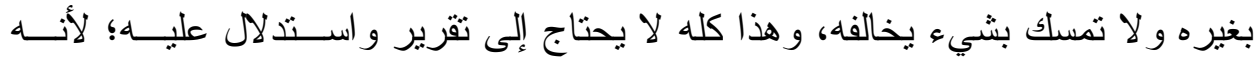

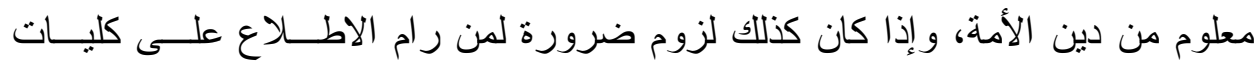

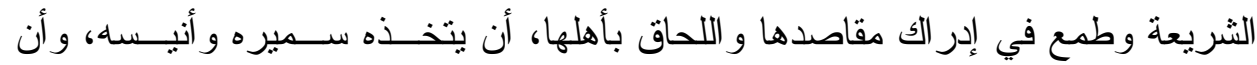
يجعله جليسه على مر الأيام و الليالي نظر اً وعملاً" (ن).

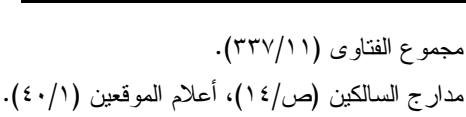

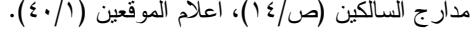

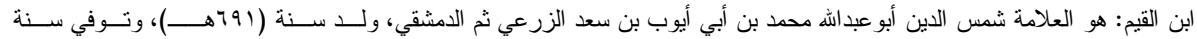

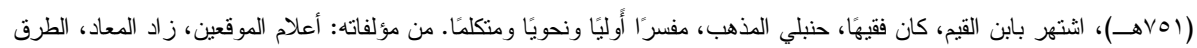




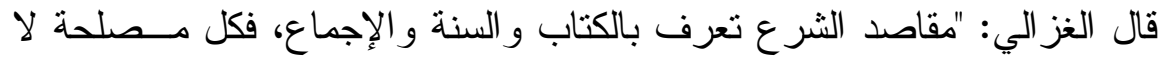

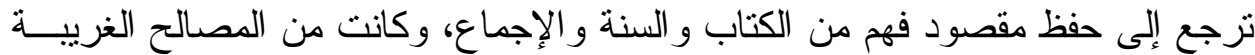

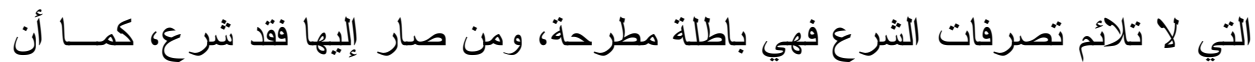

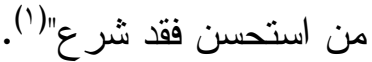

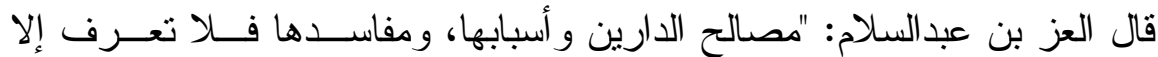

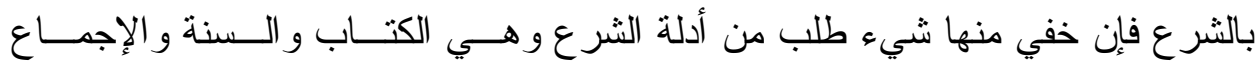

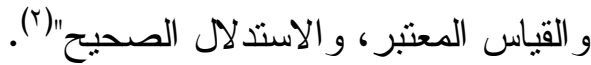

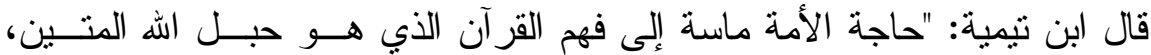

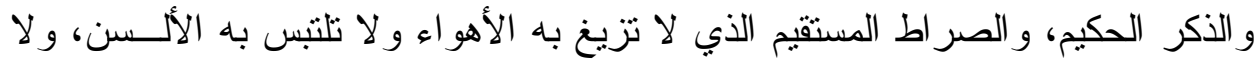

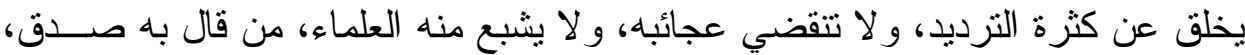

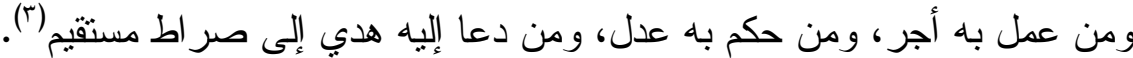

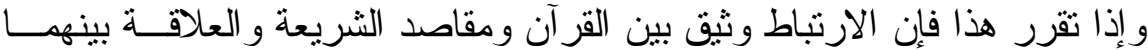

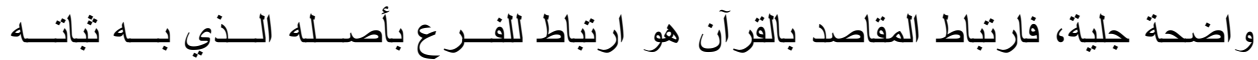

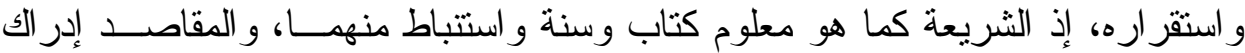
أهداف الكتاب و السنة و غايتهما في التشريع(ء).

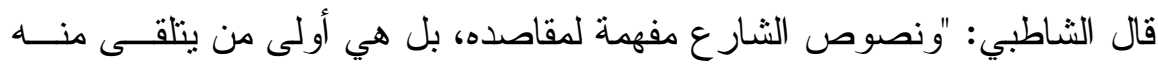

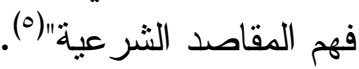
أهمية القرآن في بيان المقاصد الشرعية ترنكز في أمرين:

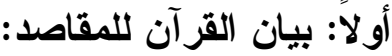

الأمور التي عني القرآن ببيانها مقاصد النتريع العامة و الخاصة، وحفظ كليـات الشريعة من ضروريات وحاجيات وتحسينات سأذكر بعض الآيات الدالة على ذلك.

$$
\text { المستصفى (T/Y) }
$$

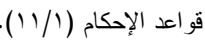

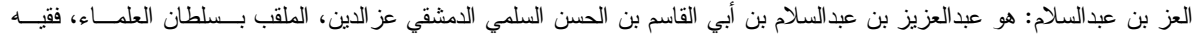

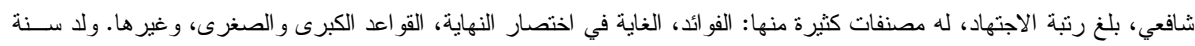

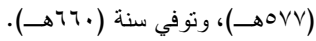

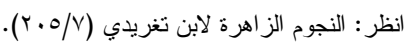

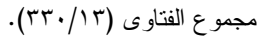

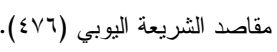

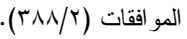


الآيات الدالة على المقاصد العامة في الثريعة الإسلامية:

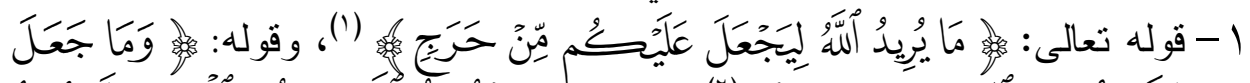

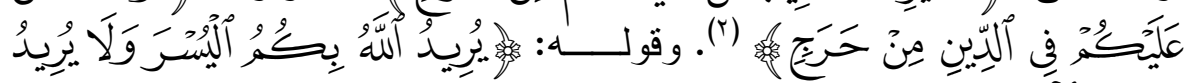

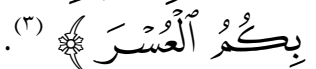

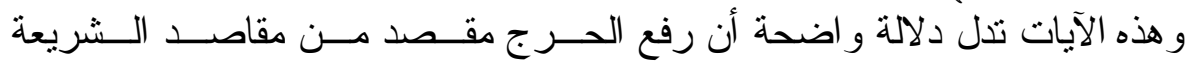
الإسلامية الذي تسعى لتحقيقه.

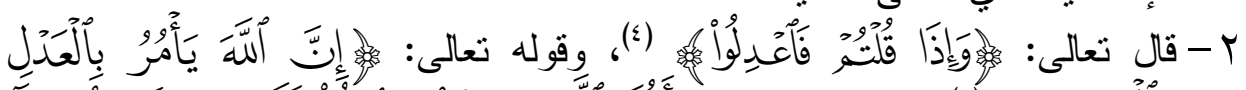

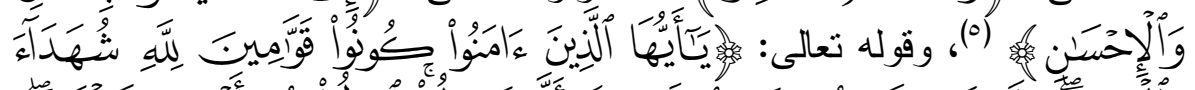

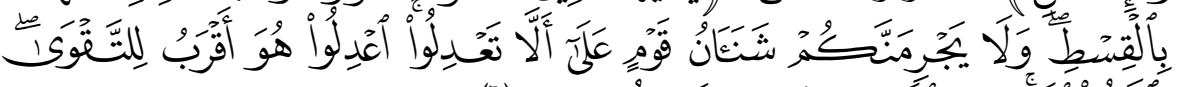

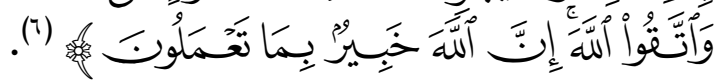

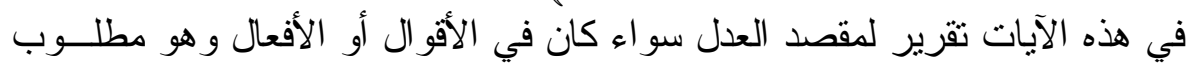

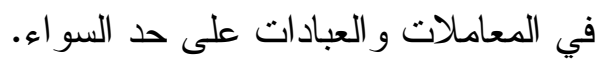

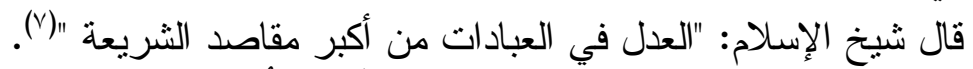

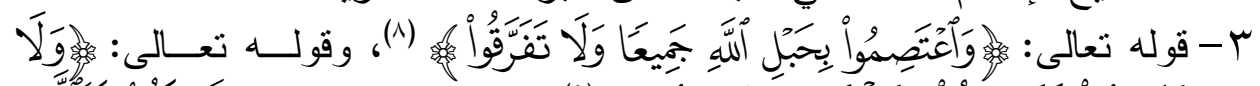

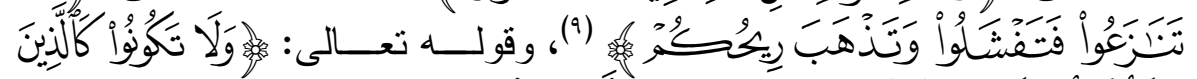

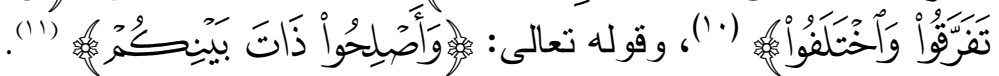

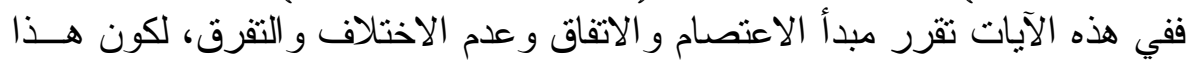

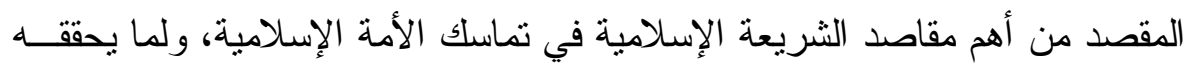
من نتائج مثرة للدين من هيبة في نفوس أعدائه.

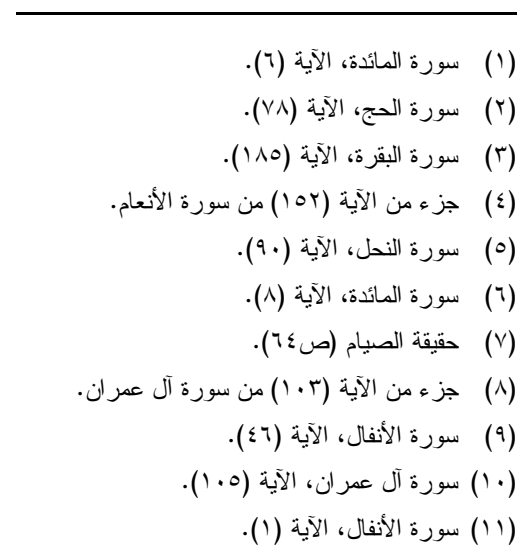




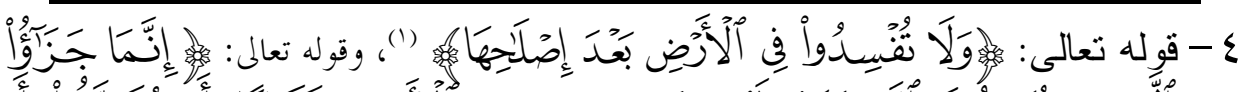

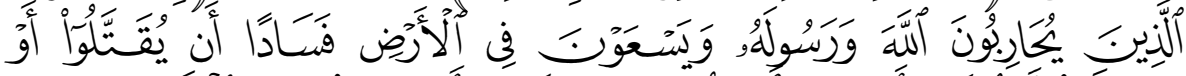

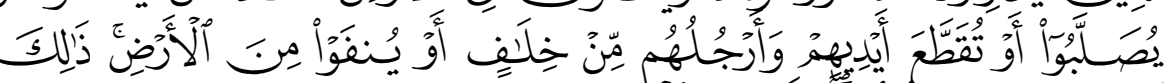

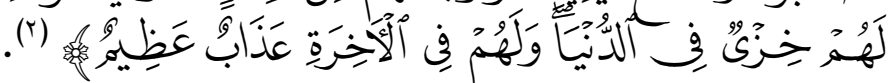

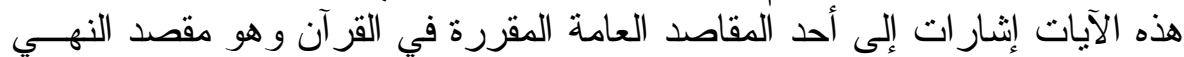

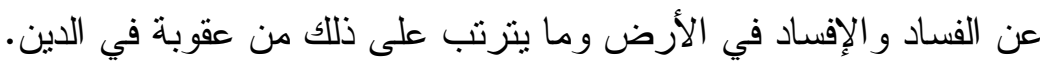

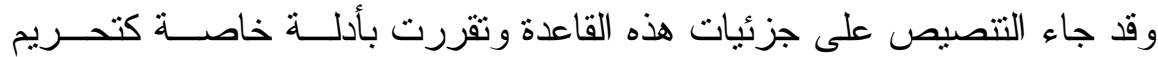

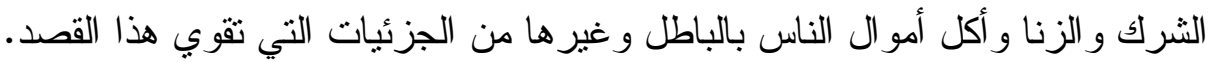
و الآيات الدالة على الدقاصد الخاصة في الثرالئ الثريعة الإسلامية، منها:

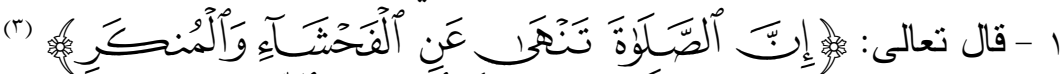

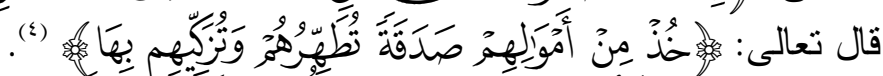

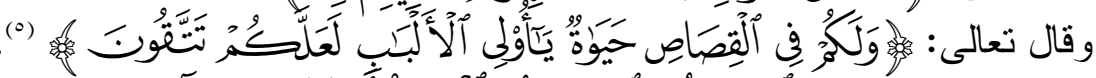

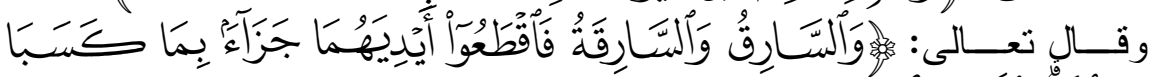

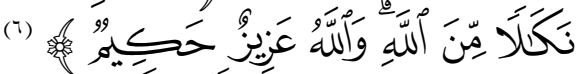

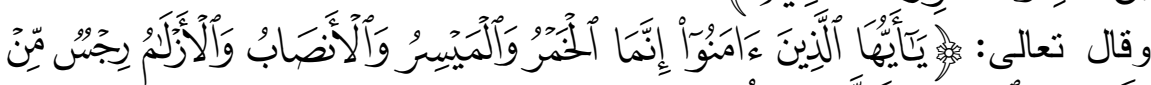

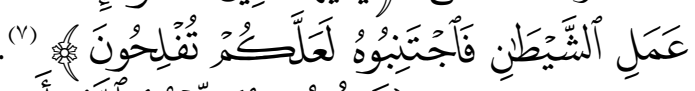

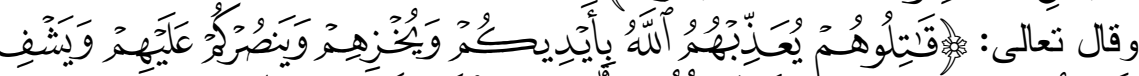

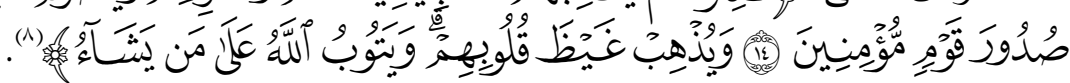

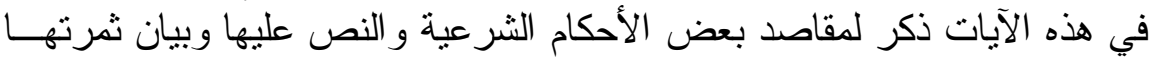

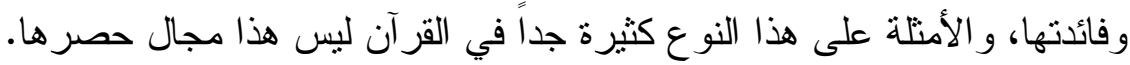

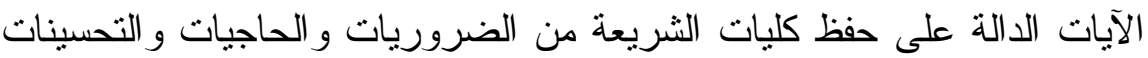

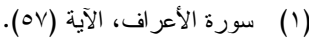

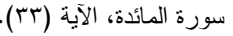

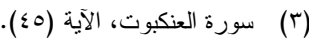

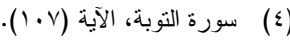

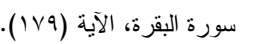

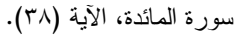

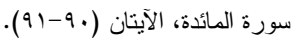

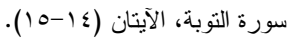




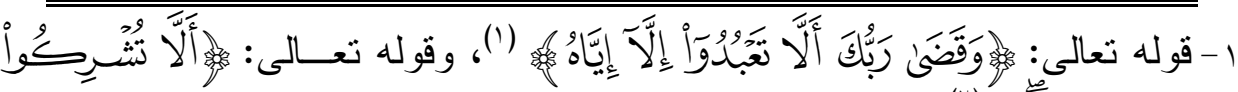

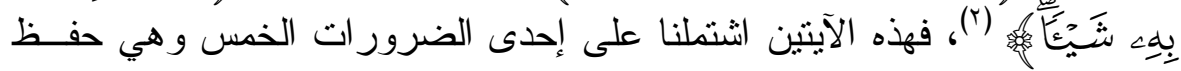
الدين.

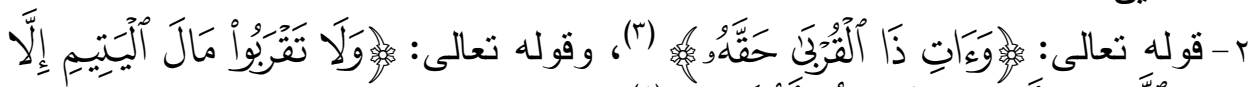

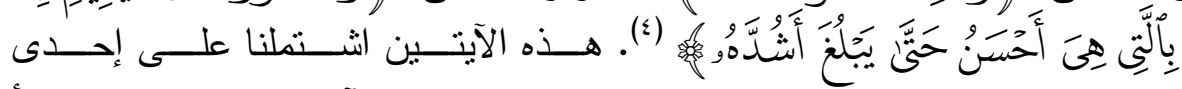

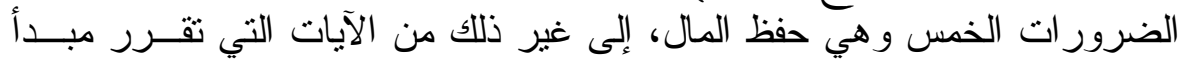
الحفظ على الضروريات الخمس.

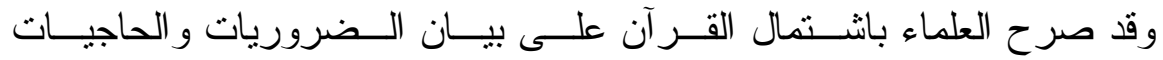
و التحسينات و المحافظة عليها من ذلك:

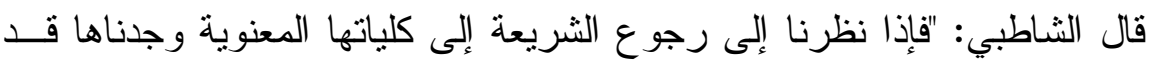

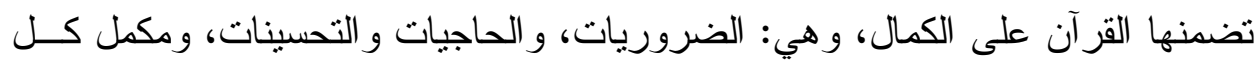
و احد منها وهذا كله ظاهر "(0).

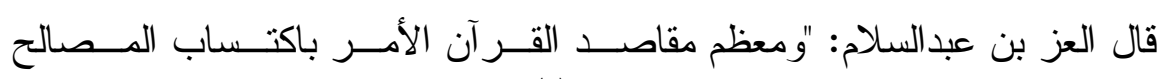

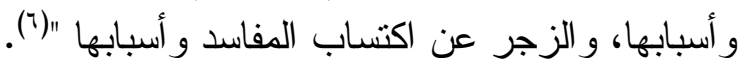

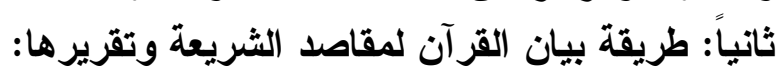

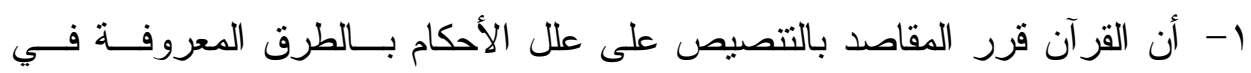
مسالك العلة، وهي أكثر من أن تحصى هندا.

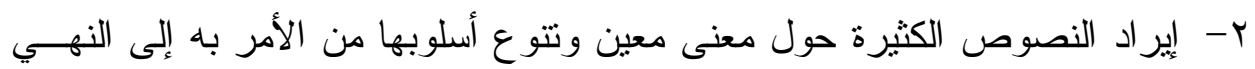

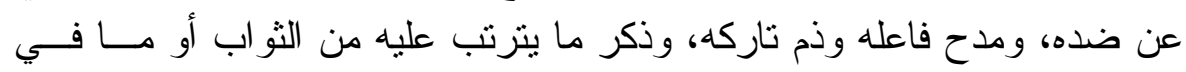

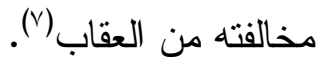


مثنال ذلك:

أعظم مقاصد الثريعة: عبادة الله وحده، ونجد أن هذا المعنـى قــرر بأســاليب

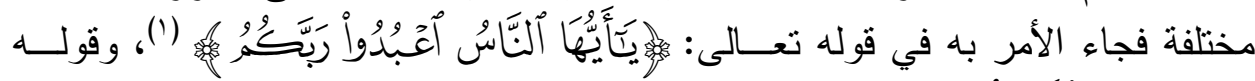

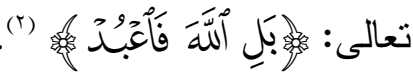

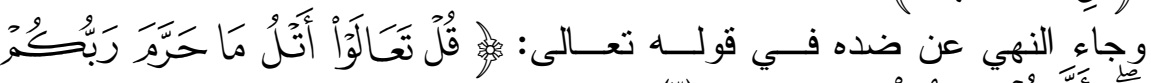

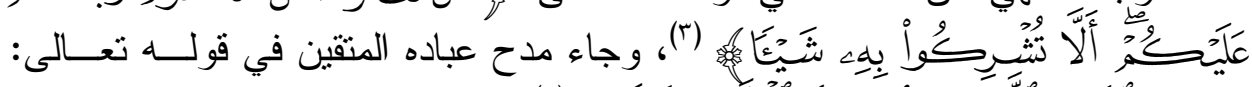

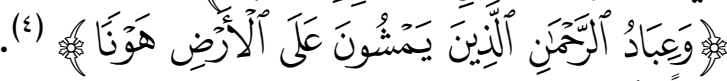

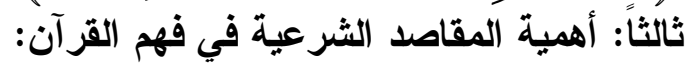

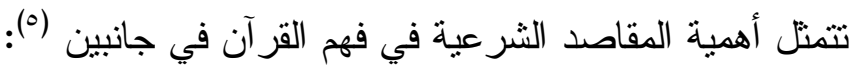

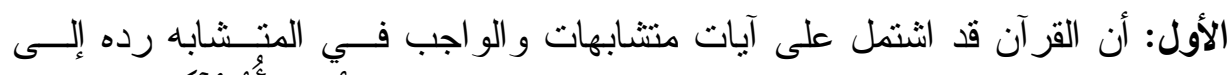

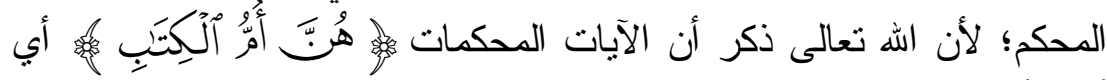

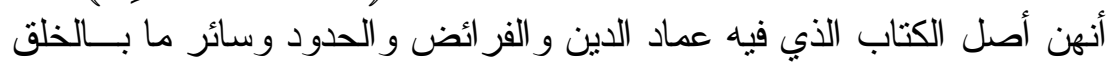

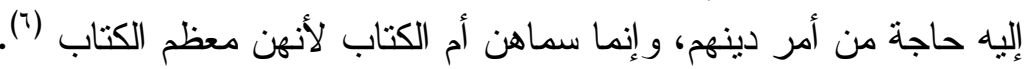

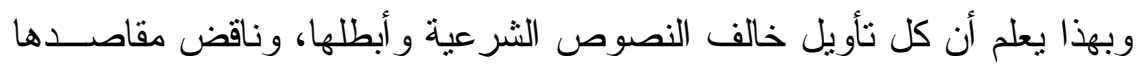

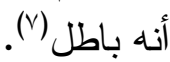

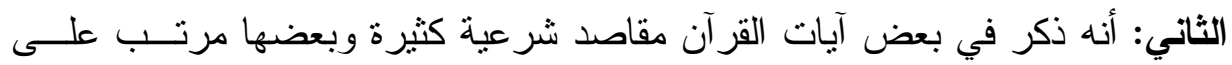

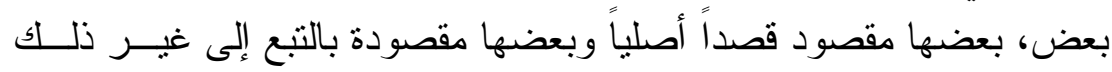

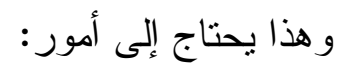

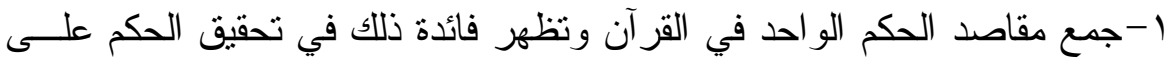
أفضل الوجوه كما أر اده الله بشر عاده.

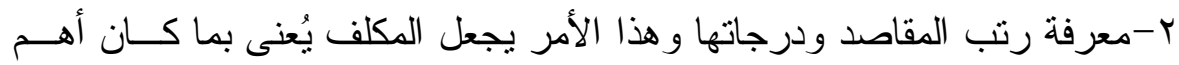

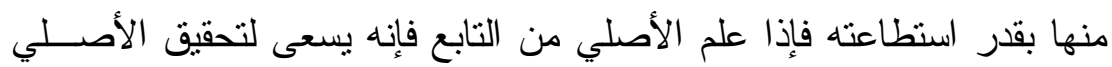

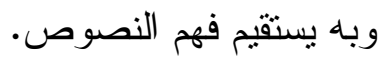


ץ- ضم مقاصد السنة إلى الكتاب؛ لأن السنة مفسرة للكتاب، ومؤكد لـــه، ومنــشئة

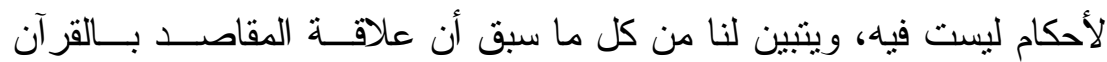

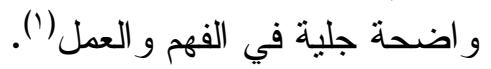
المسألة الثانية: علاقة المقاصد بالسنة: أولاً: تعريف السنة لغة والئة علة المطلاحاً:

تعريف السنة لغة:

السنة لغة: الطريق المسلوك حسياً كان أو معنوياً. و السنة تطلق في اللغة على الطريقة مطلقاً سو اء كانت حسنة أو قبيحة.

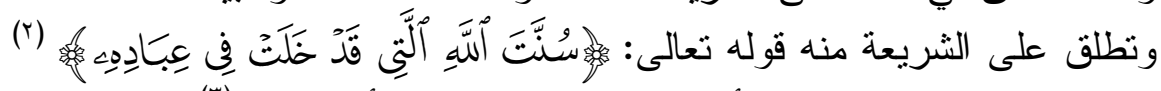

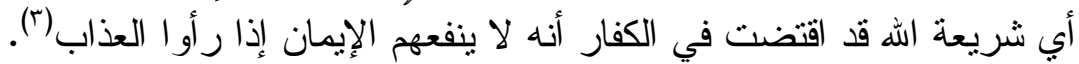
تعريف السنة اصطلاحاً:

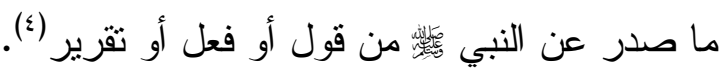
ثانياً: حجية السنة:

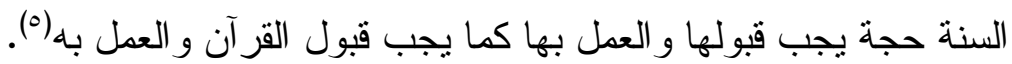

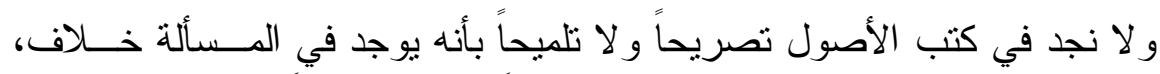

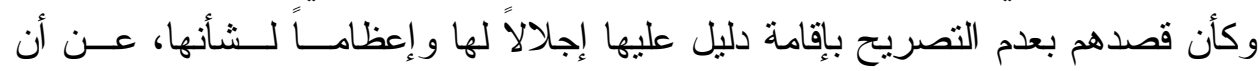

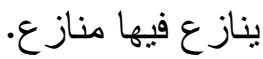
و هناك من العلماء من نص على ضع ضروريتها.

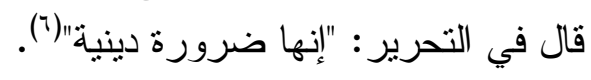
قال في إرشاد الفحول: "اعلم أنه قد اتفق من يعتد به من دن أهل العلم على أن السنة

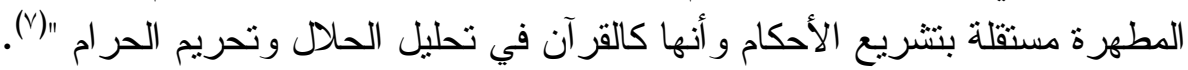

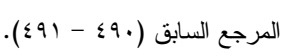

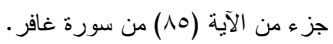

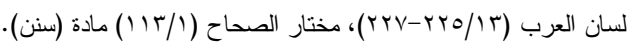

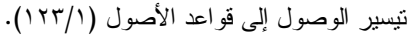

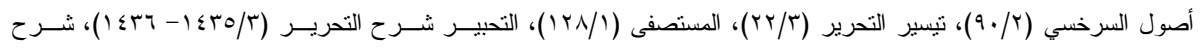

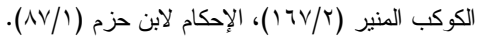

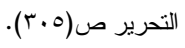

$$
\begin{aligned}
& \text {.( }(\mathrm{AN} / \mathrm{M})
\end{aligned}
$$


قال في شرح الكوكب المنير: "و أقسام السنة كلها حجة تصلح أن يحتج بها علـى

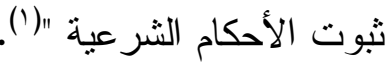

وبعدما سبق من أقو ال العلماء يتبين لنا أنه كيف يتصور أن يكون النزاع في هذه النه

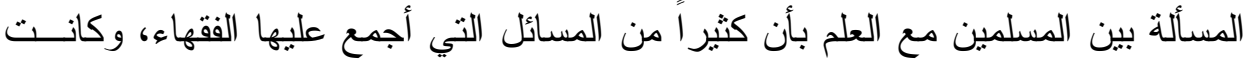
معلومة من الدين بالضرورة منوقفة عليها (كعدد ركعات الصلاة).

ثالثاً: علاقة المقاصد بالسنة:

تتضح علاقة المقاصد الشرعية بالسنة فيما يلي (؟):

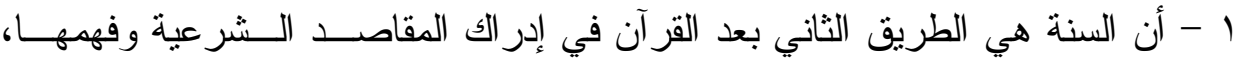

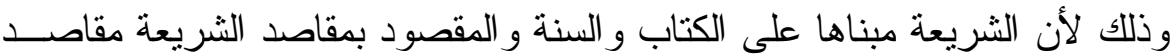

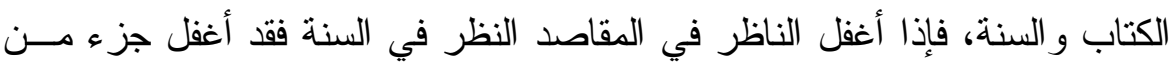

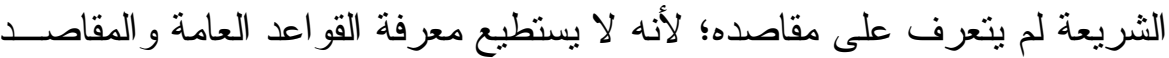
الكلية إلا بعد النظر في الثريعة كاملة كتاباً وسنة. قال الثاطبي: "وقد كملت قو اعد الشريعة في القرآن و السنة فلم يتخلف عنها شئهيء

و الاستقر اء يبين ذللك ويسهل على من هو عالم بالكتاب و السنة "(").

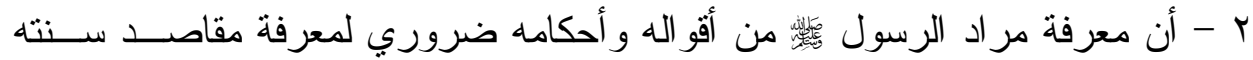
و الجهل بذلك جهل بمقاصده.

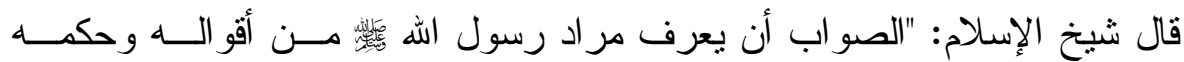

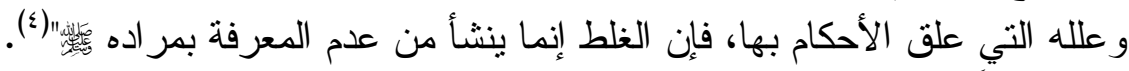

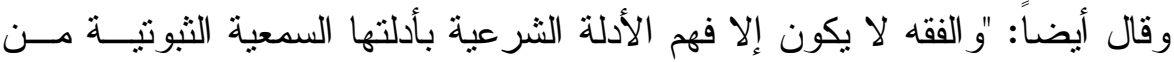

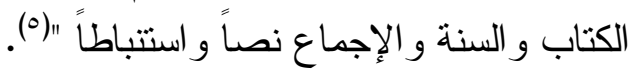

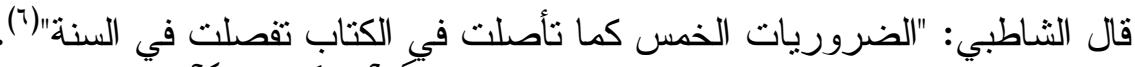

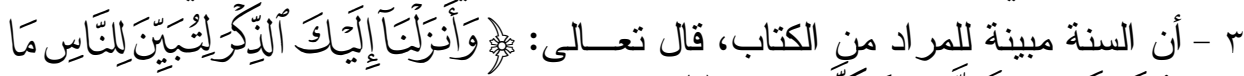

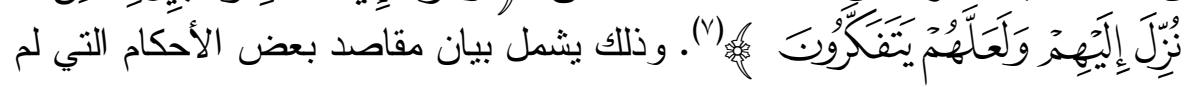

الاستقامة (T/1) (T).

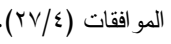


ينص القر آن على مقاصدها، لم يبين غايتها، كما يـشمل زيــادة إيـضـاح وبيــان

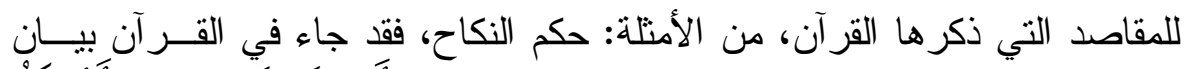

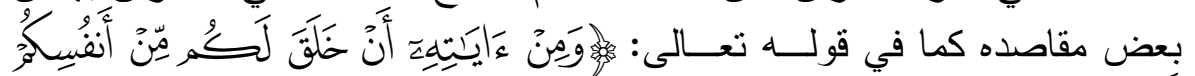

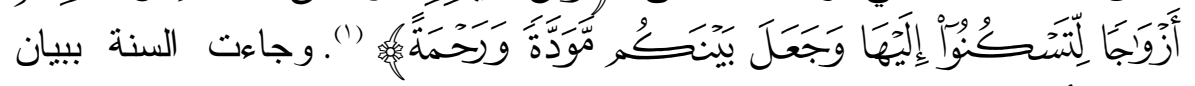

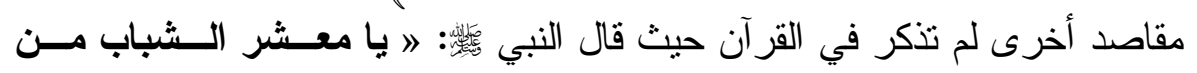

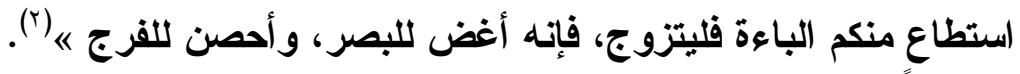

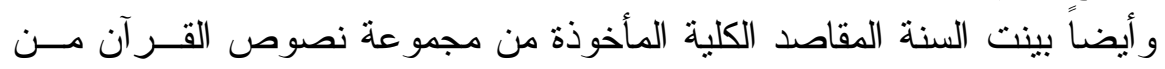

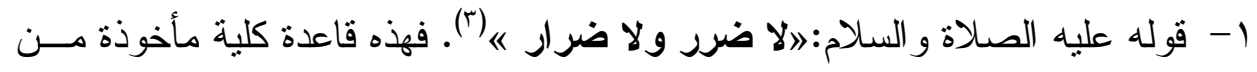
نصوص كثثرة في القرآن تنفي الضرر، وأن من مقاصد الشريعة الإسلامية رفعه.

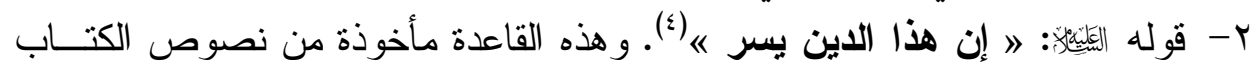

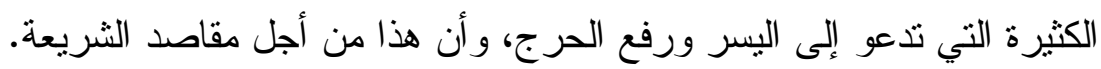

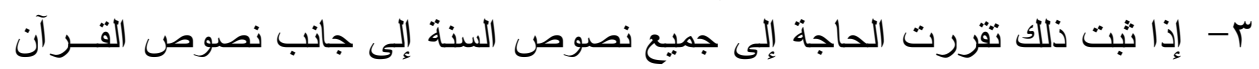

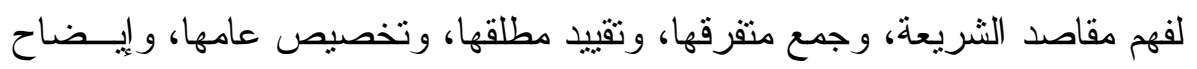
مشكلها.

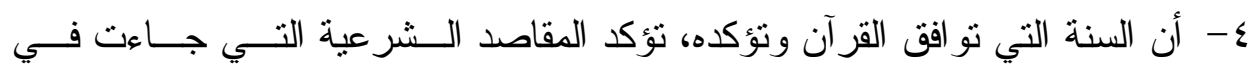
الكتاب وترسخها، فهي تعمل على رو عايتها وتثبيتها وحفظها.

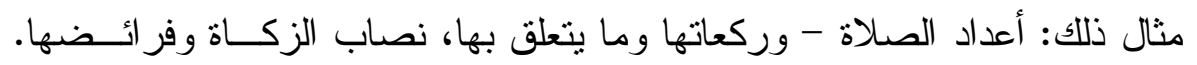

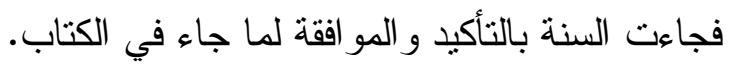

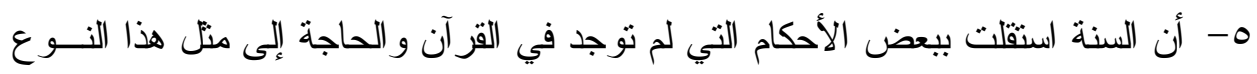

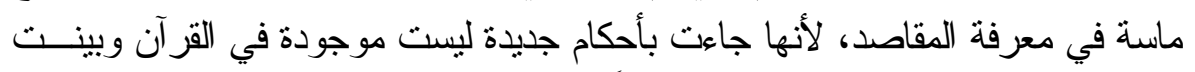

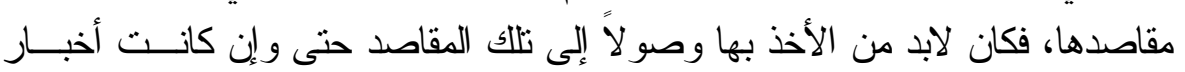

آحاد (०).

سورة الروم، الآية (·r).

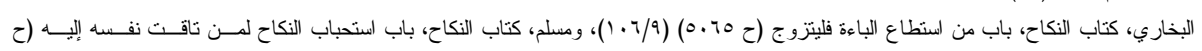

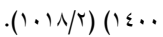

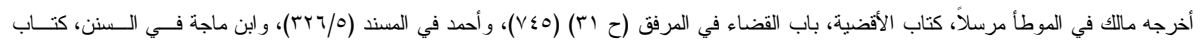

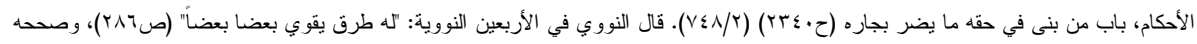

الألباني في إرواء الغليل (r/ ـ ؟ ؛).

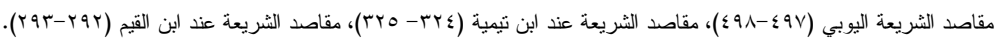

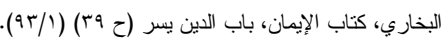


المسألة الثالثة: علاقة المقاصد بالإجماع: أولاً: تعريف الإجماع لغة و اصطلاحاً:

تعريف الإجماع لغة: الإجماع في اللغة بطلق على معنيين هما ('):

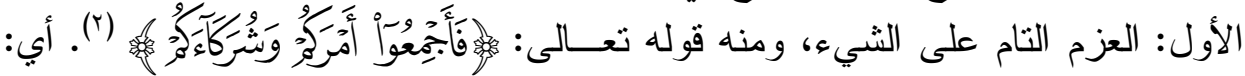

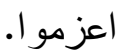

الثاني: الاتفاق، يقال: أجمع القوم على كذا: إذا اتفقو ا.

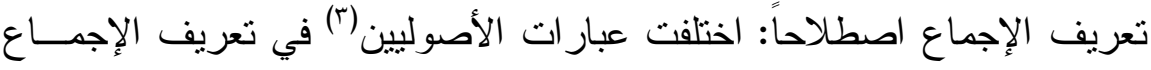

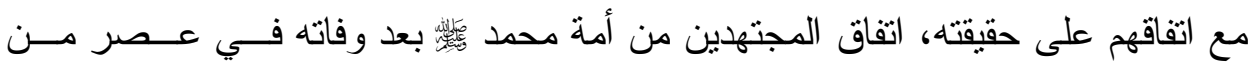

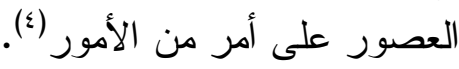

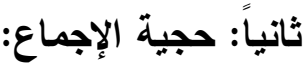
الإجماع حجة معتبرة شر عاً بإجماع العلماء متى انعقد وفق شروطه المعتبرة ولم

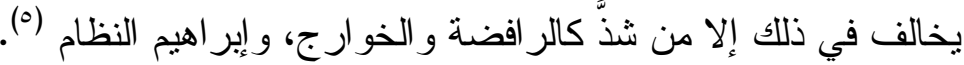
وقد استذل الأصوليون على حجية الإجماع من الكتاب و السنة.

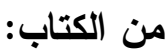

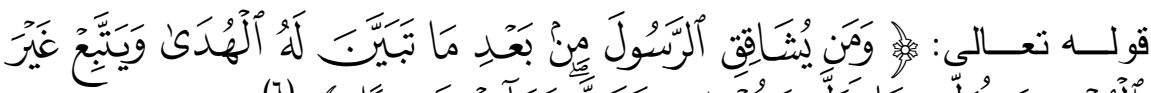

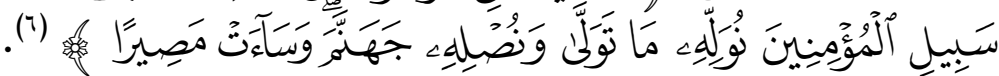

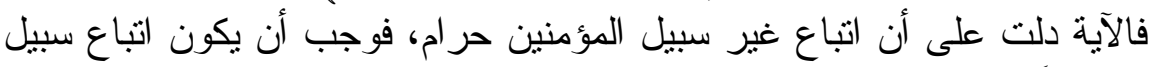
المؤمنين و اجباً.

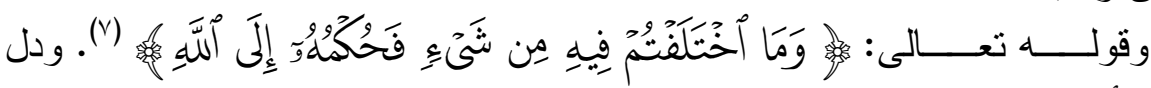
بمفهومه أن ما اتفقتم عليه فهو حق. تقو:

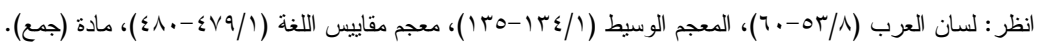

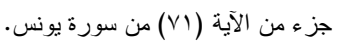

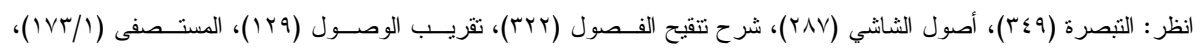

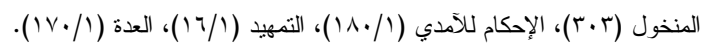

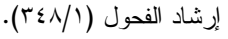

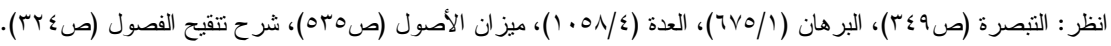

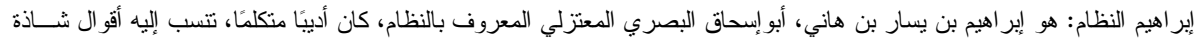

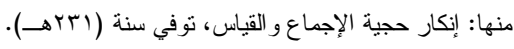

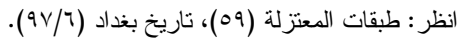

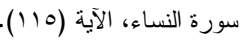

جزء من الآية (•) سورة الآلة (1) (1) الشورى. 
قوله عله

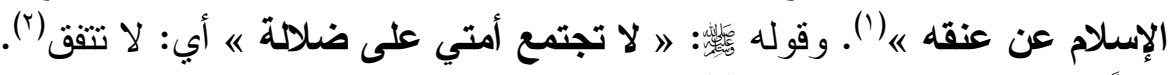

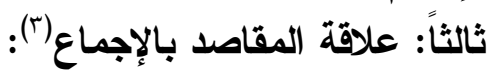

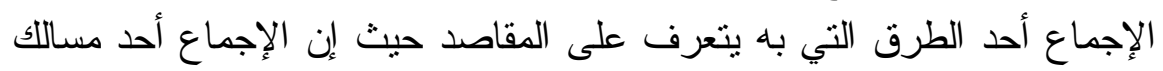
العلة التي بها يُتبت المقاصد، بل من أهم مساللك العلة الإجماع.

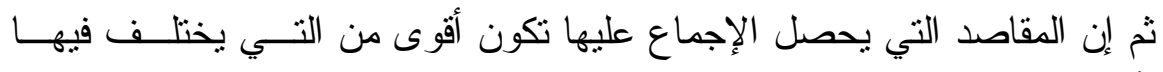
وتظهر أهمية ذلك في الترجيح بين المقاصد. فأهمية الإجماع للمقاصد تتمثل في ناحيتين:

الثانية: تقوية المقاصد (؟). الأولى: التعرف على الإجماع لمعاصداصد المقاصد. أهمية المقاصد في الإجماع: 1- أن الإجماع لا ينعقد إلا بعد اتفاق جميع مجتهدي الأمة، فالاجتهاد شرط في حصول

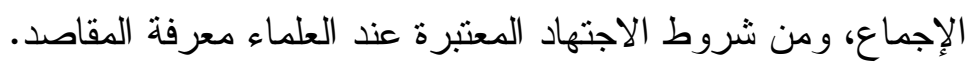

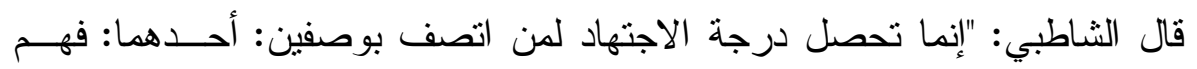
مقاصد الثريعة على كمالها.

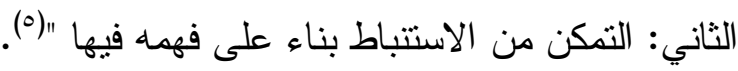

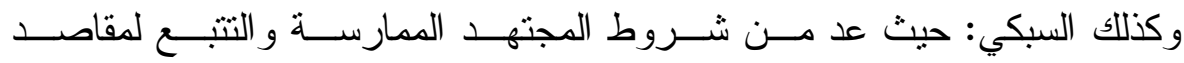

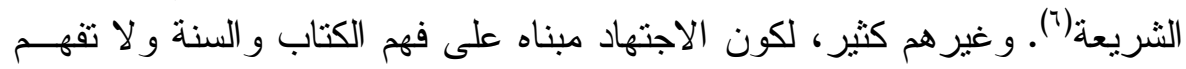
إلا بفهم مقاصدها الخاصة و العامة.

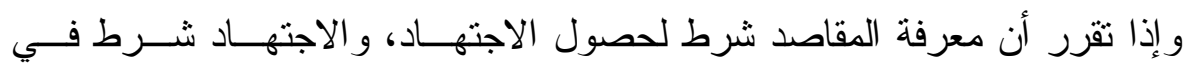

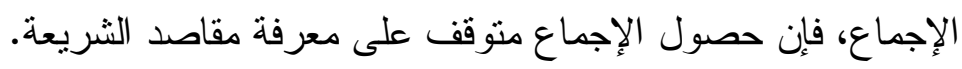

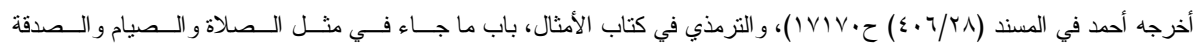

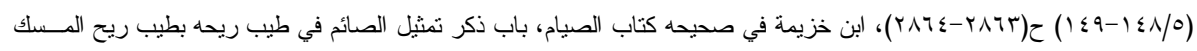

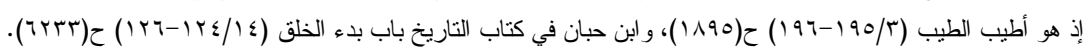

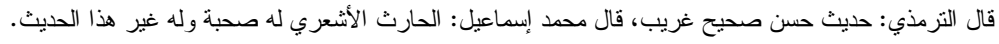

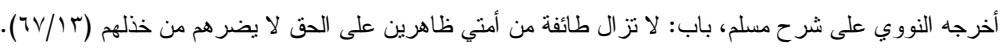

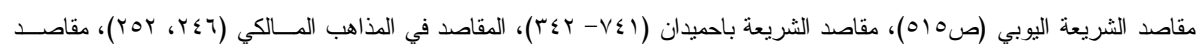

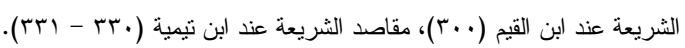

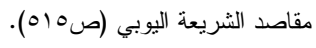

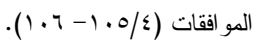$$
\text { الإبهاج (1) }
$$ 
Y- أن الإجماع قد يستتد إلى نص من الكتاب أو السنة، وقد يستتد إلى اجتهاد ورأي(')،

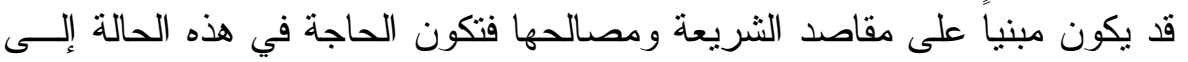

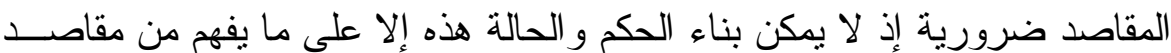

$$
\text { الثار ع ونصوصه. }
$$

من الأمثلة:

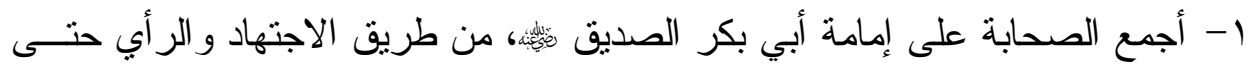

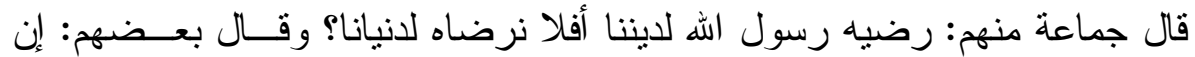

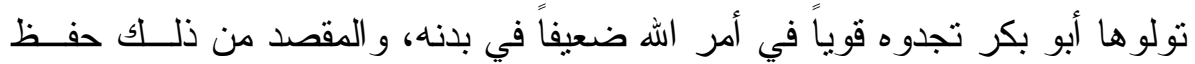

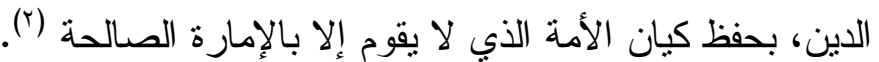

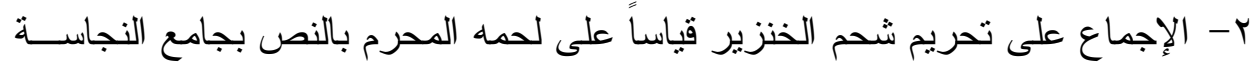

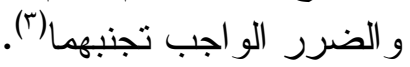
r- الإجماع على جمع القر آن في عهد أبي بكر لمصلحة حفظه وصيانته من الــضياع أو التحريف. ع - تضمين الصناع و المقصد في حفظ أمو ال الناس وسد حاجاتهم من الصناعة.

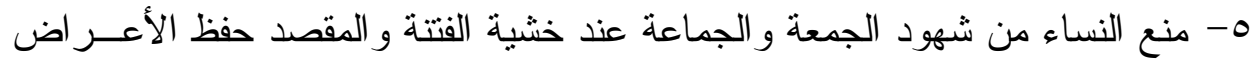
وسد ذريعة الفساد (؛).

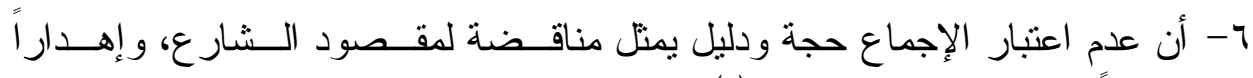

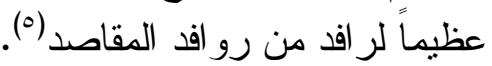
المسألة الر ابعة: علاقة المقاصد بالقياس: أولاً: تعريف القياس لغة لغة واصطلاحاً:

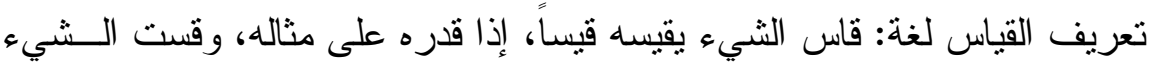
بغير إذا قدرته على مثاله، ويقاس بأبيه أي يسلك سبيله ويقتدي بهـه

مسألة انعقاد الإجماع مستتداً إلى الر أي و الاجتهاد، اختلف العلماء فيها على أقو ال:

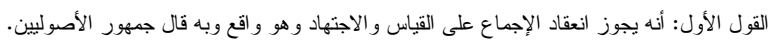

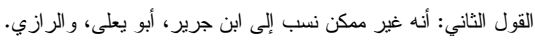

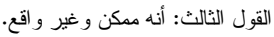

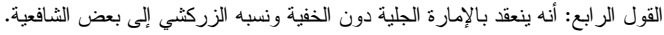

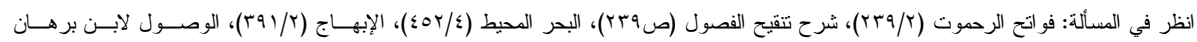

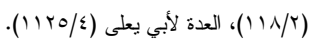

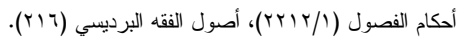

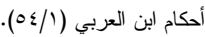

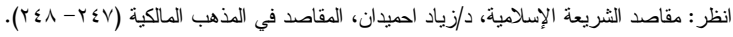

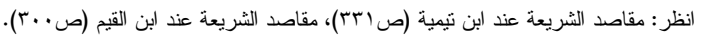




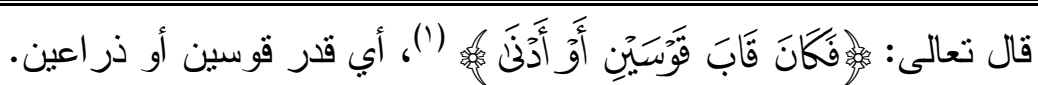

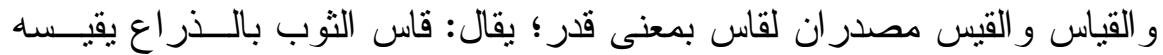

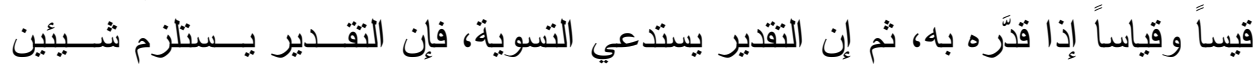

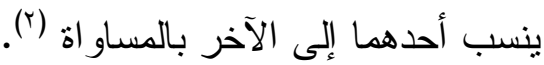

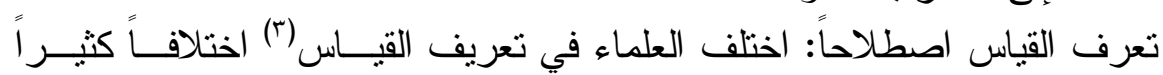
و السبب في اختلاف التعاريف هو الاختلاف في القياس، هل هو دليل مستقل من أدلــــة الشرع، أو هو من فعل المجتهد.

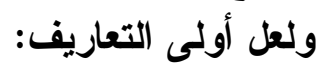

تعريف البيضاوي: "إنثات منل حكم معلوم في معلوم آخر لانشتر اكهما فــي علـــة

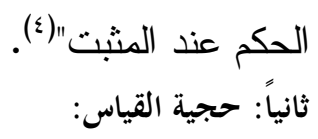
تحرير محل النزاع في المسألة:

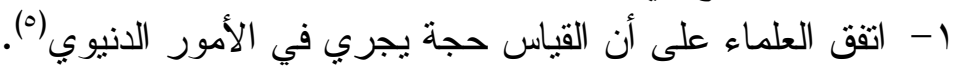

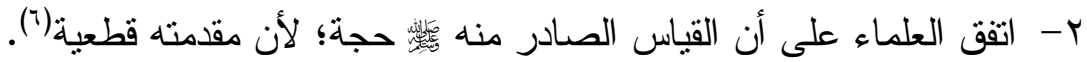
r- اختلف العلماء في القياس في الأمور الثرعية على لقئ قولين:

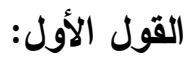

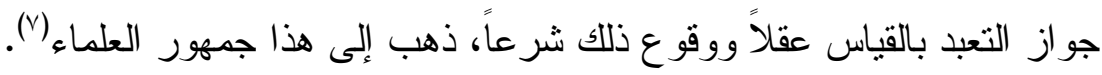
القول الثاني: - التو

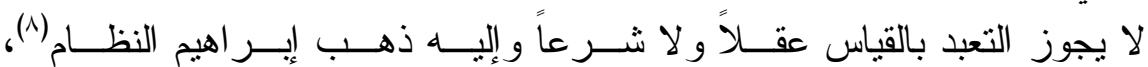
و الظاهرية(")، وطائفة من الرو افض و أكثر فرق الخو ارج (·' (').

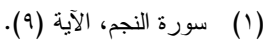

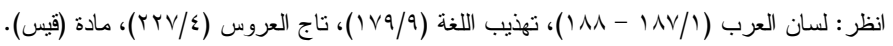

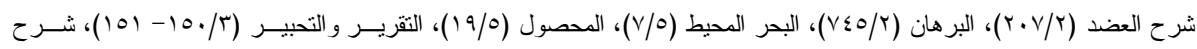

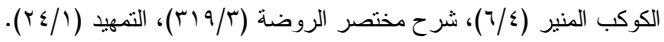

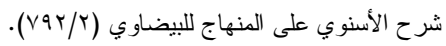

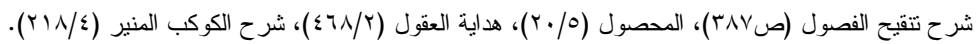

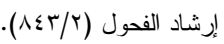

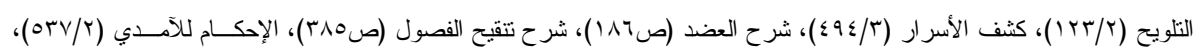

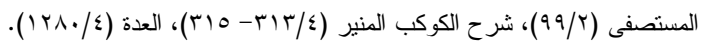

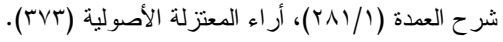

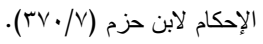

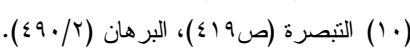




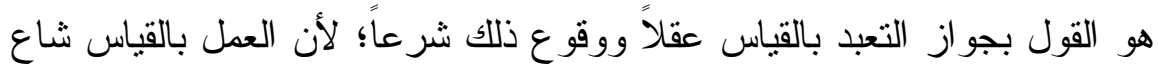

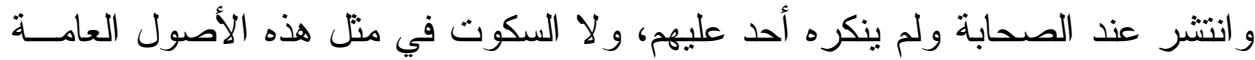

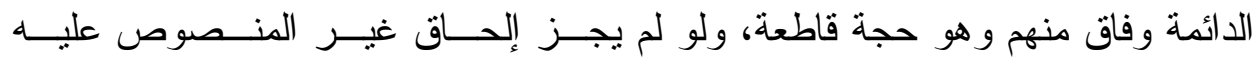
بالمنصوص عليه لم يكن لذكر العلل فائدة.

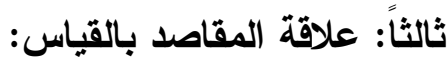

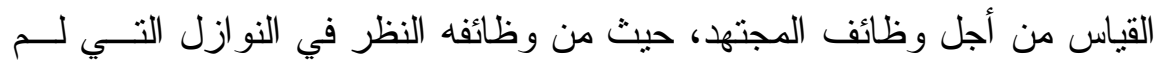

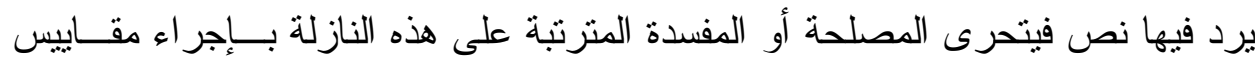
الثريعة التي قامت على اعنبار المقاصد بمر اتنها الثلاثة.

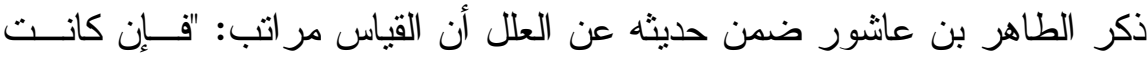

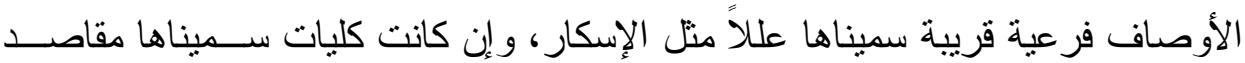

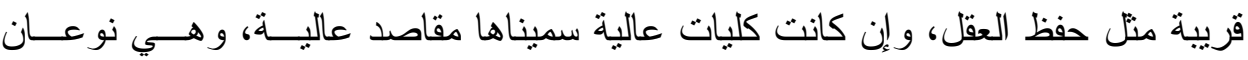
مصلحة ومفسدة" (1).

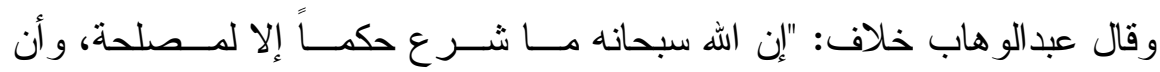

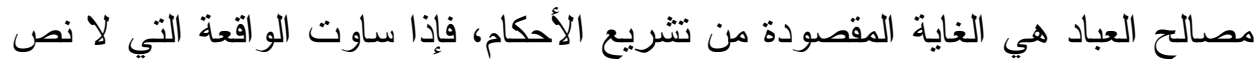

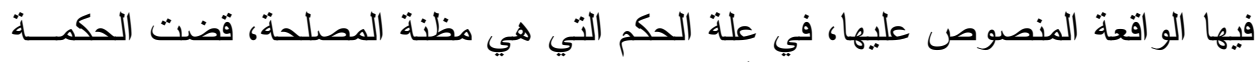

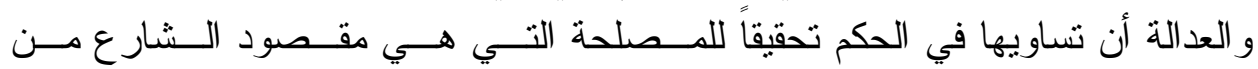

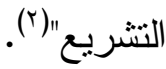

ومن مباحث القياس التي لها علاقة وصلة بالمقاصد المناسبة و العلة و الحكمة. علاقة المقاصد بالعلة: ورد في تعريف كثير من الأصوليين تعريف العلة بكونها

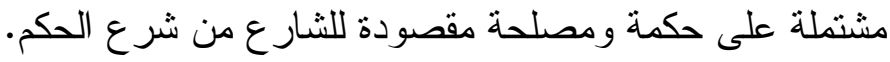
عرفها الآمدي: "العلة هي الأصل بمعنى الباعث، أي مشتملة على حكمة صنّة صالحة

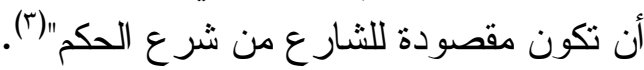

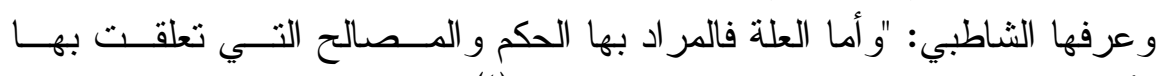

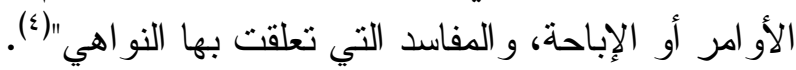

كلم أصول الفقه (صNه). 


\section{علاقة المقاصد بالمناسبة (')}

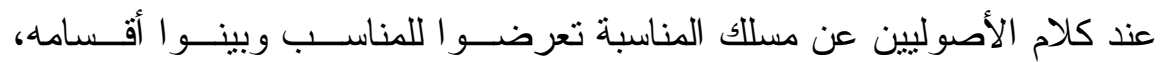
وذكروا ما يصح التعليل به منها وما لا يصح، وتعرضو البحث مقاصد الثريعة وبينــوا بعض أقسامها.

قال الغز الي: "وجميع أنو اع المناسبات ترجع إلى رعاية المقاصد وما انفك عـن إنى

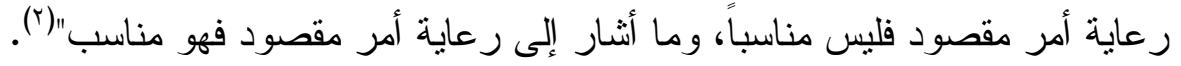
ومن المباحث التي تعرضو الها مما يتعلق بالمقاصد:

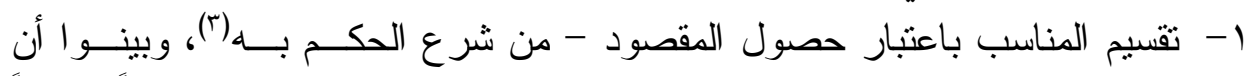

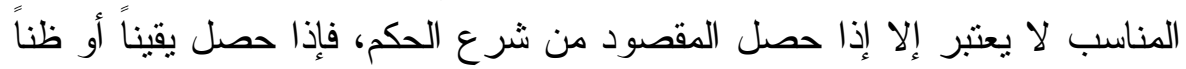

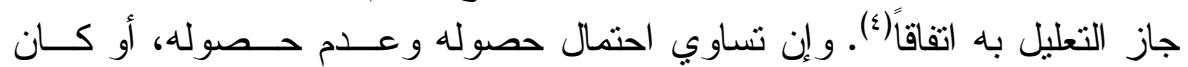

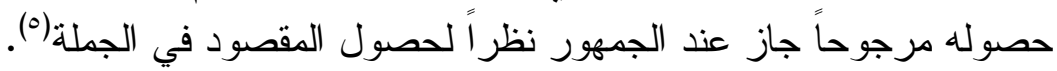

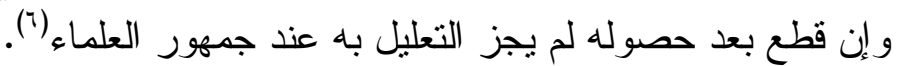

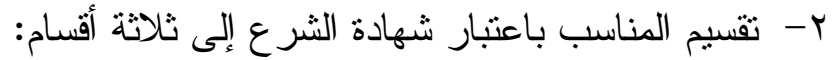
أ - قسم علم من الثر ع باعنباعنباره. ب - قسم علم من الثر عن علم عدم اعتباره.

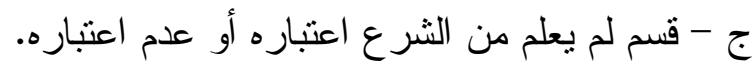

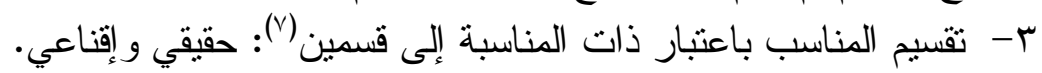

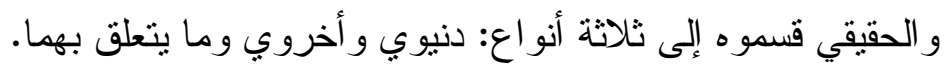

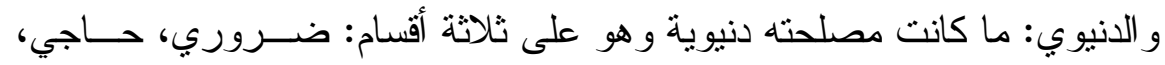
تحسيني.

و الأخروي: ما كانت مصلحته تتعلق بالآخرة، كتزكية النفس وتهذيب الأخلاق.

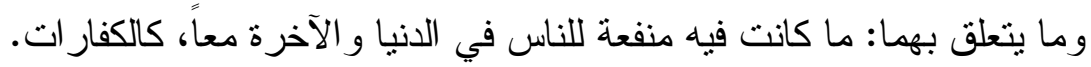

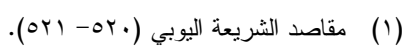

$$
\begin{aligned}
& \text { (r) شفاء الغليل ص(109). }
\end{aligned}
$$

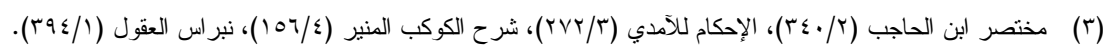

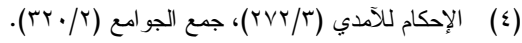

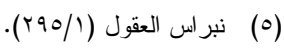

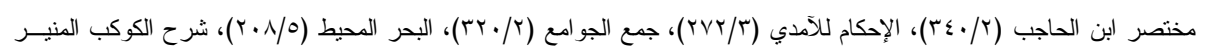

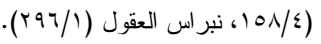

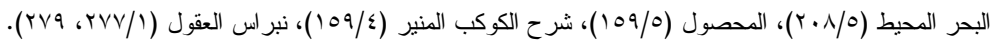


وما ذكره الأصوليون في القسم الدنيوي من أقسام هي التي تعد أســاس اعتبــار

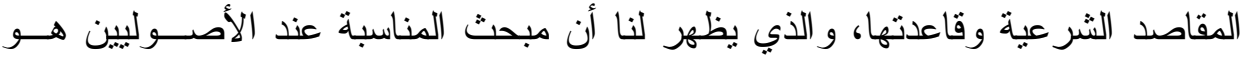

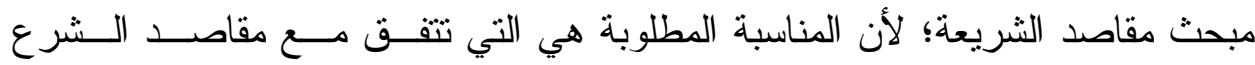
و اعتبار اته.

\section{علاقة المقاصد بالحكمة:}

من المباحث التي بحثها الأصوليون في القياس التعليل بالحكمة وهي التي لأجلها صار الوصف علة (').

وعرفت الحكمة بأنها: "جلب مصلحة أو تكميلها أو دفع مفسدة أو تقليلها"(؟).

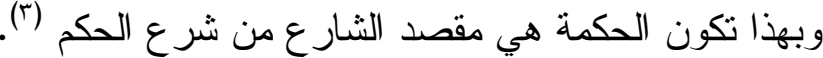

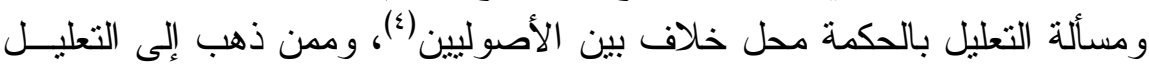

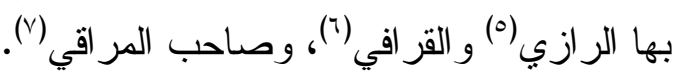

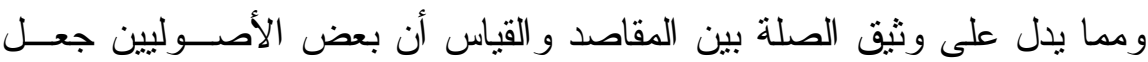
المقاصد أنفسها أوصافاً.

قال ابن السبكي: "المناسبة: المناسب ما يجلب للإنسان نفعاً أو يدفع عنه ضرر اً"، ألفاء قال: عرف المناسب بأنه الذي يجلب للإنسان نفعاً أو يدفع عنه ضرر ال.

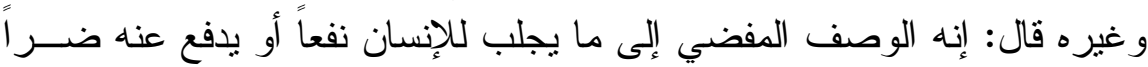

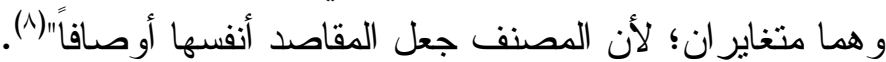
ثبين لنا مما سبق العلاقة بين المقاصد و القياس، فالقياس ركنه الأهم العلة، و العلة

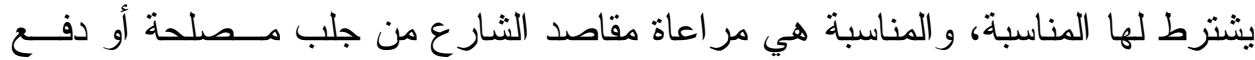
مفسدة.

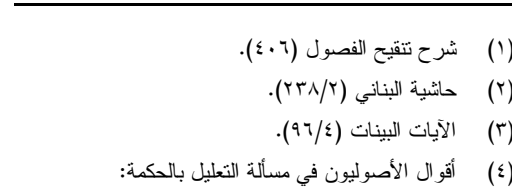

القول الأول: لا يجوز التعليل بها مطلقاً نسبه الآمدي إلى الأكثر.

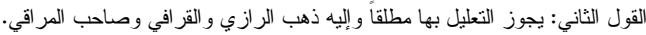

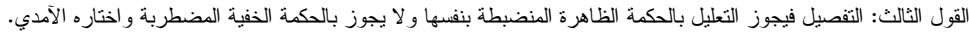

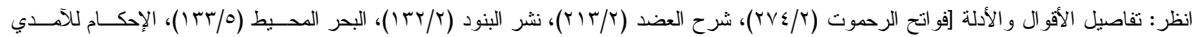

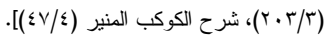

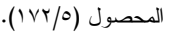

شرح تنقيح الفصول (ך • §).

نشر البنود (T/T/T)

الإبهاج (T/r) 
المطلب الثاني: علاقة المقاصد بالأدلة المختلف فيها

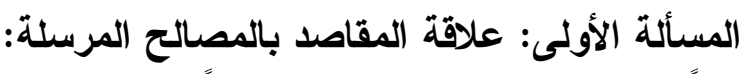

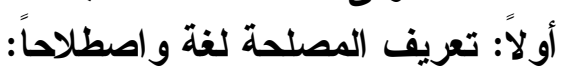

تعريف المصلحة لغة: الصاد و اللام و الحاء أصل و احد بدل على خلى خلاف الفساد.

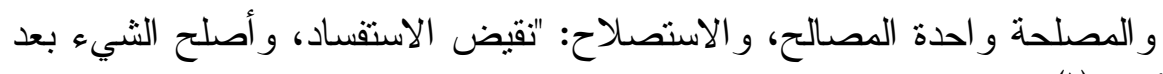

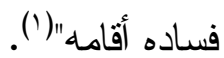

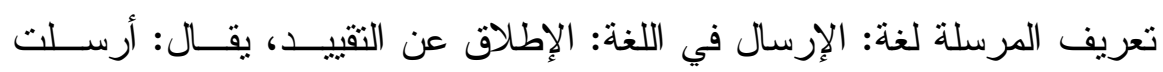

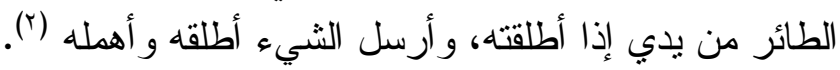

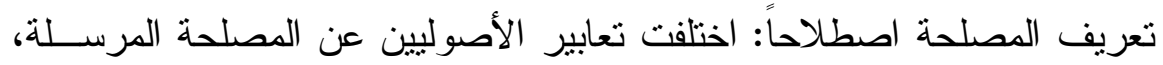

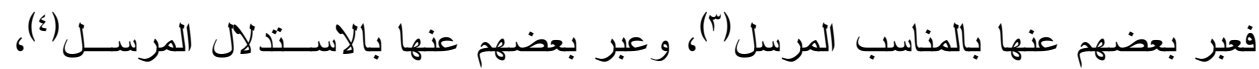

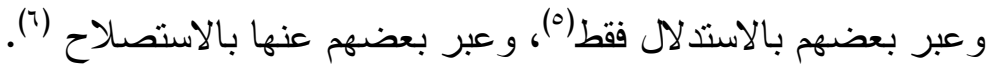

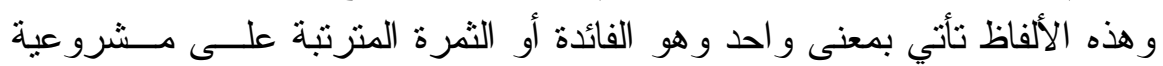

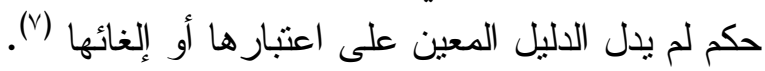
المر اد بالمصلحة المرسلة: المبل المبل

الوصف المناسب لتشريع الحكم لم يشهد له الشار ع بالاعتبار أو الإلغاء(^). ثانياً: حجية المصلحة المرسلة:

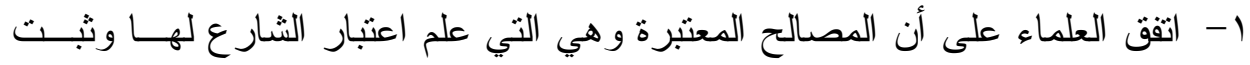

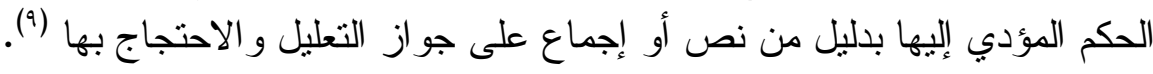

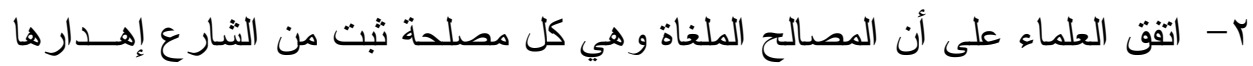

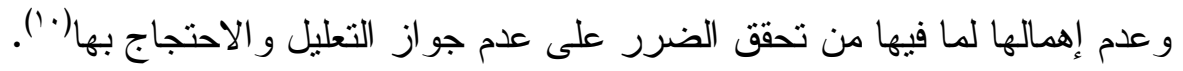

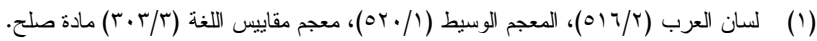

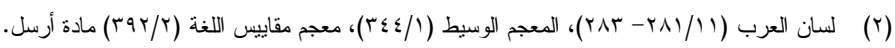

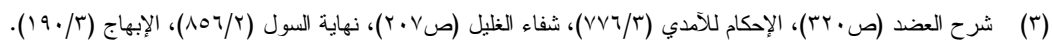

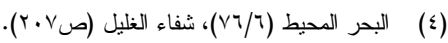

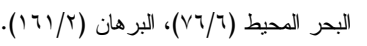

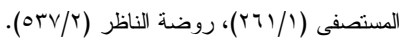

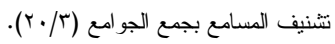

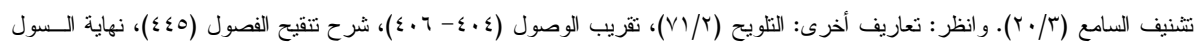

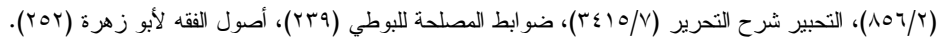

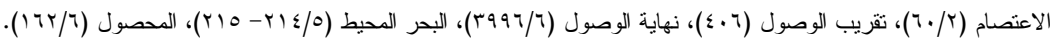

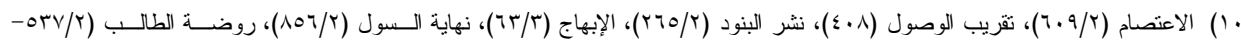


r- اتفق العلماء على عدم الاحتجاج بالمصلحة المرسلة في باب العبادات و المقـدر ات

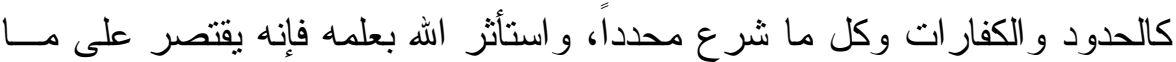

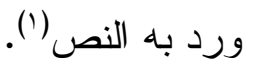

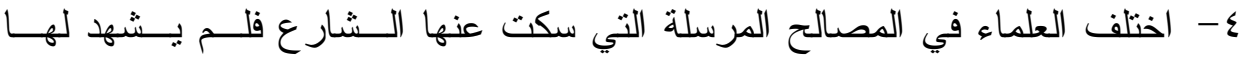
بالاعتبار أو الإلغاء في غير العبادات و المقدرات على ألقوال:

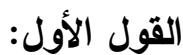

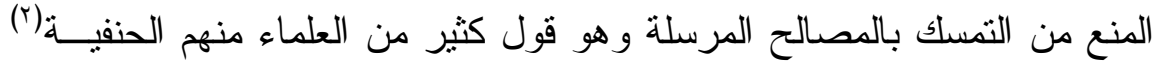

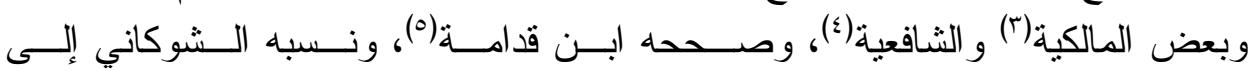

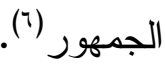

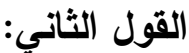

جواز التمسك بالمصلحة المرسلة وهو مذهب مالك("vان.

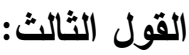

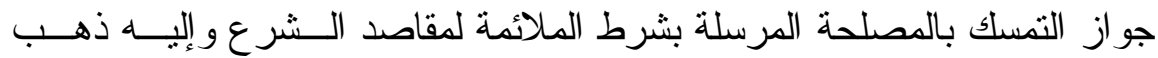

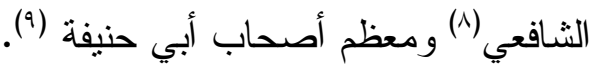

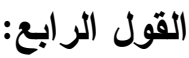

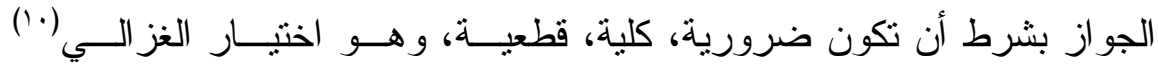
و البيضاوي(') (')

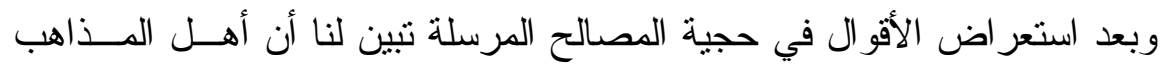

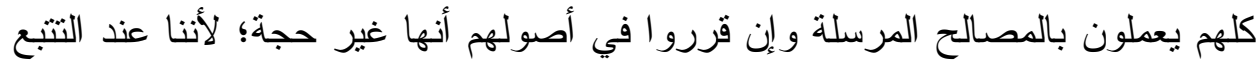
و النظر في الفروع الفقهية نجدهم يعملون بها، وهذا يدل على إعمالهم لها.

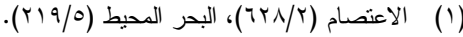

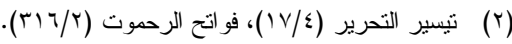

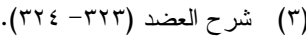

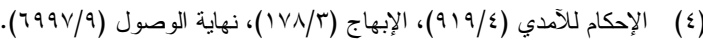

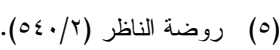

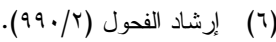

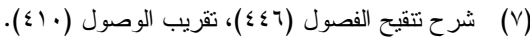

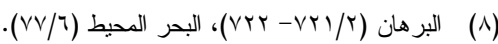

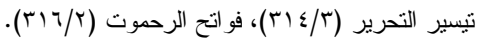

$$
\begin{aligned}
& \text { ( ) }
\end{aligned}
$$

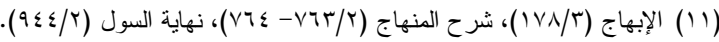


فيما يلي عرض لبعض النصوص من كتب مذاهبهم تدل على ذلك:

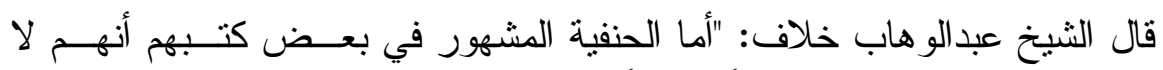

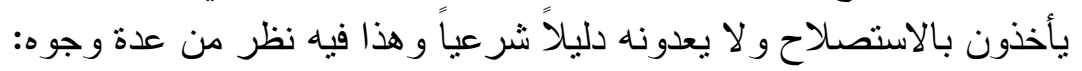

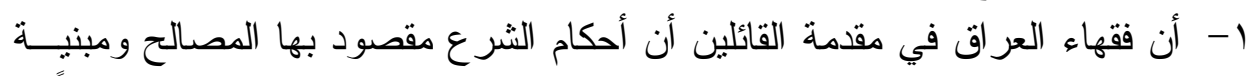

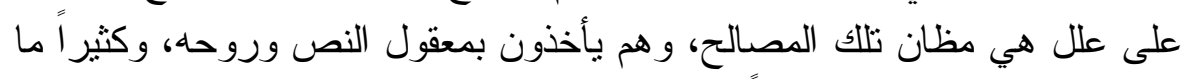

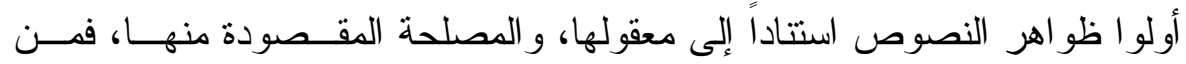

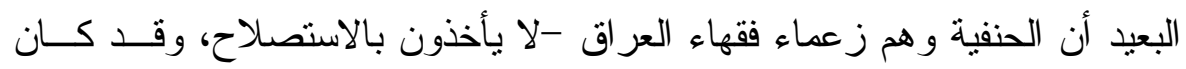

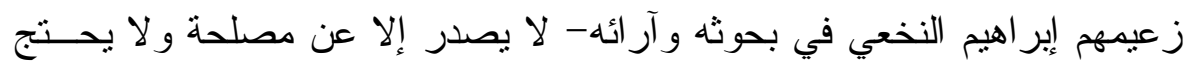
إلا بالمصلحة.

r- أنهم قالو ا بالاستحسان وجعلو ا من أنواع الاستحسان الذي سنده العرف و الضرورة

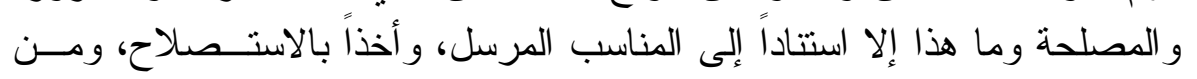

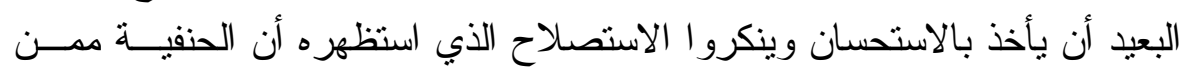
يحتجون بالاستصلاح" (1) وقال الرازي: "بعد ذكره أنو اع المصالح ودلائل اعتبار ها: فدل مجموع ما ذكرنا

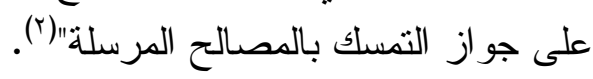

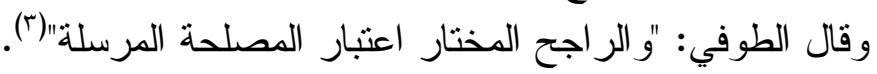

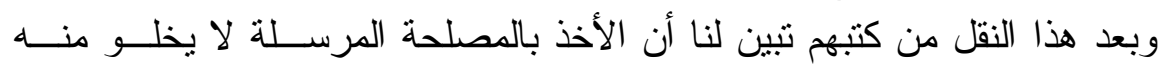
مذهب من المذاهب الأربعة.

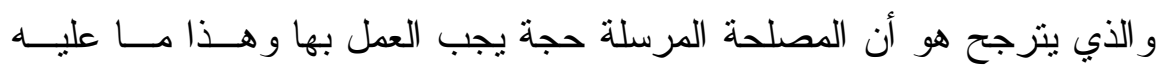
جمهور العلماء. قال القرافي مقرراً لذلك: "وقد تقدم أن المصلحة في جميع المذاهب عند التحقق؛ لأنهم

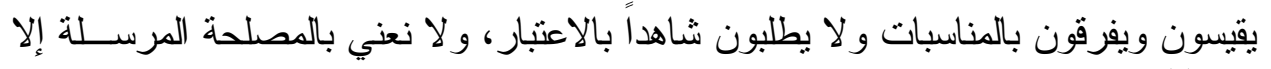
ذلك" (ई). فال ابن دقيق العيد: "الذي لا شك فيه أن لمالك ترجيحاً على غيرهـ مــن الفقهــاء

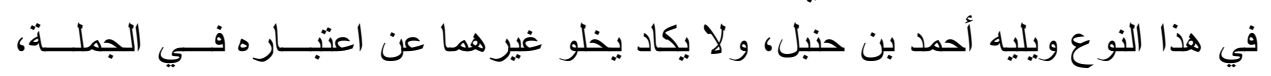

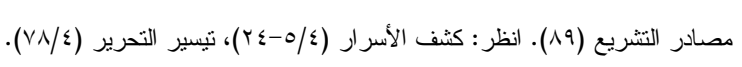

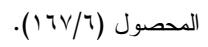

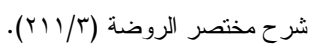

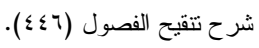




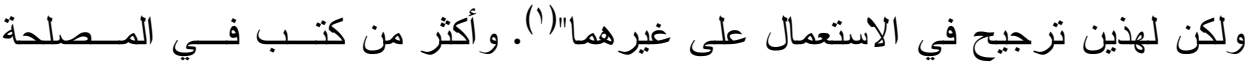

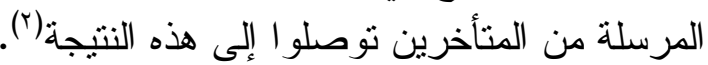

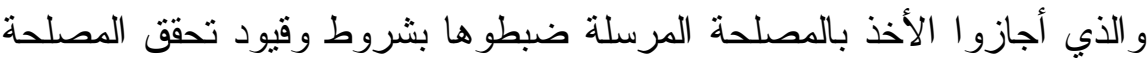

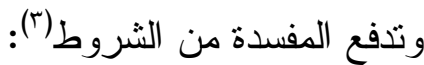
1- أن تكون ملائمة لمقاصد الثريعة.

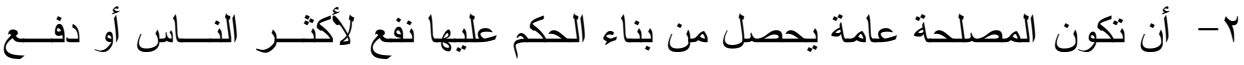

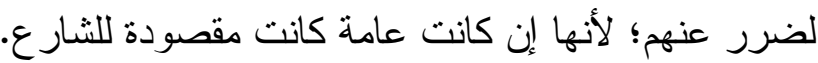

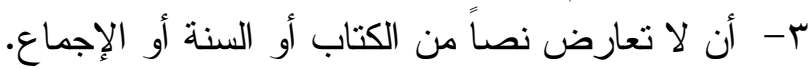
ع - أن يكون العمل بها في غير الأمور التعبدية. ثالثاً: علاقة المقاصد بالمصلحة المرسلة (؛):

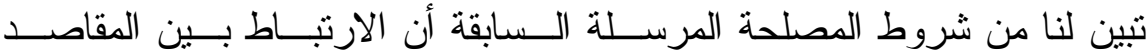

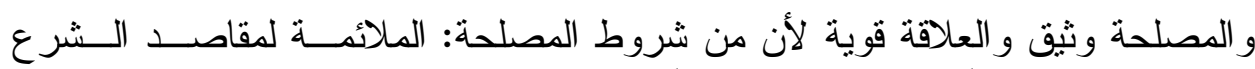

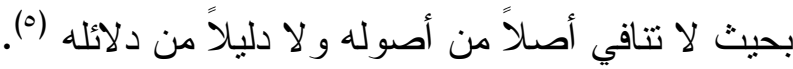

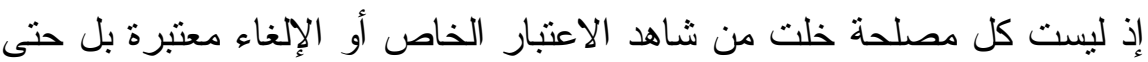
يقوم من مقاصد الثريعة ما يؤيدها.

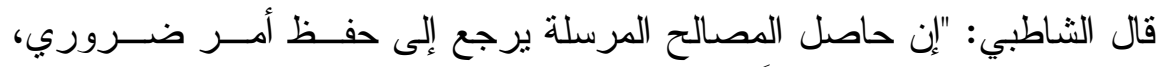

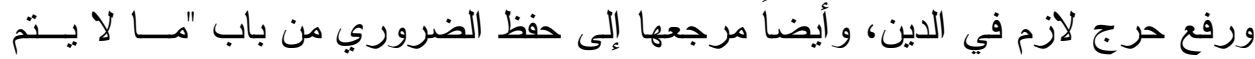

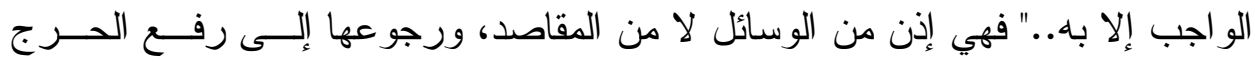

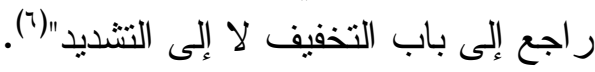

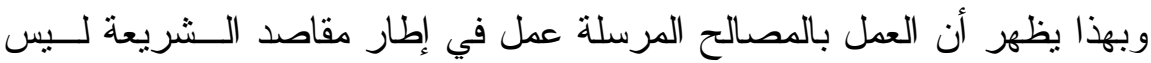

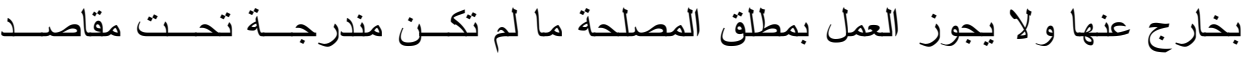

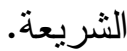

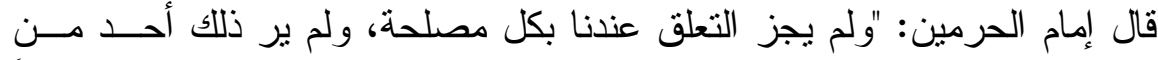

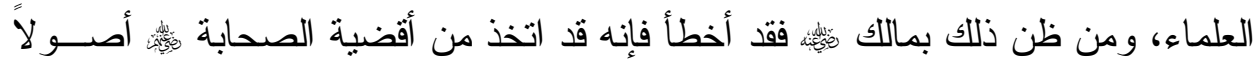
ضو ابط المصلحة للبوطي (VTV) وما بعدها، أثز الأدلة المختلف فيها للبغا (اء) وما بعدها.

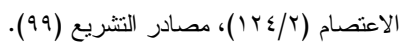

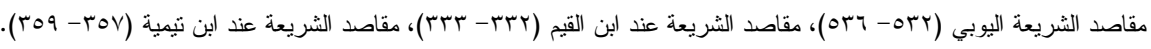

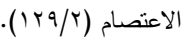

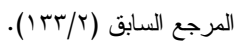


وشبه بها مآخذ الوقائع، فإذا لم يرَّ الاسترسال في المصالح، ولكنه لم يحط بنلك الوقـائع

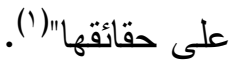
فبمر اعاة هذا الثرط وضبطه يزول تخوف بعض العلماء من أن الأخذ بالمصالح

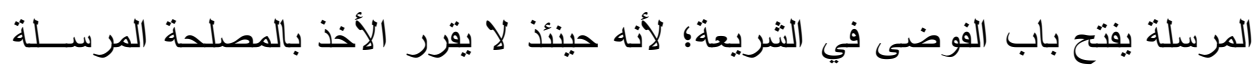

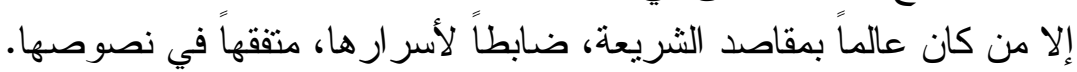

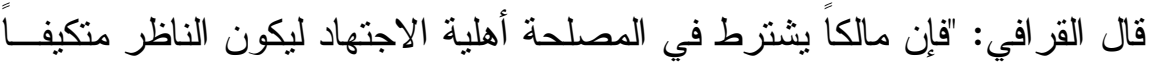
بأخلاق الشريعة فينبو عقله وطبعه عما يخالفها "(r).

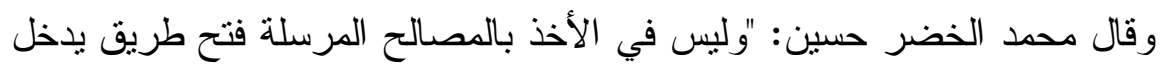

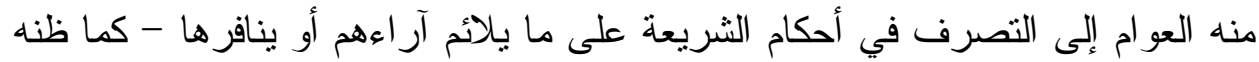

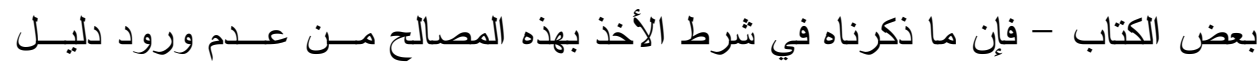

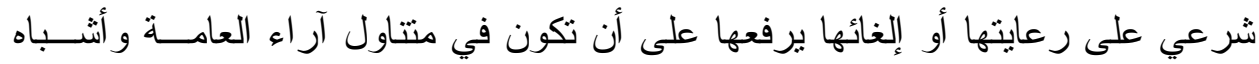

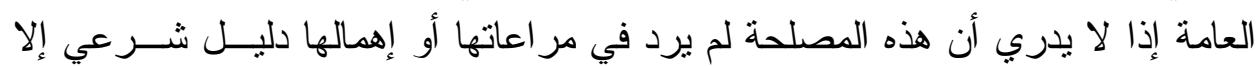

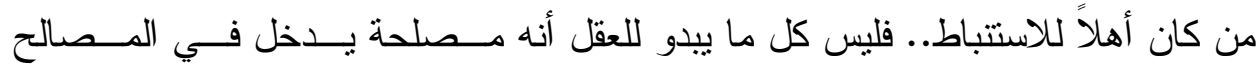

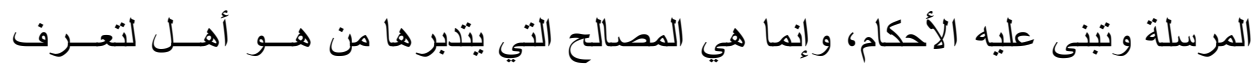

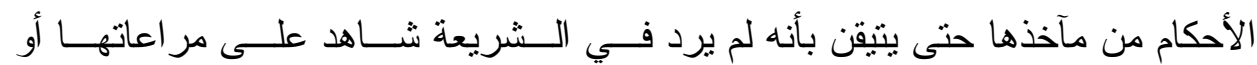

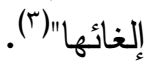

و عندما يوكل الاستصلاح للعلماء المجتهدين و المطلعين على أســرار الــشريعة

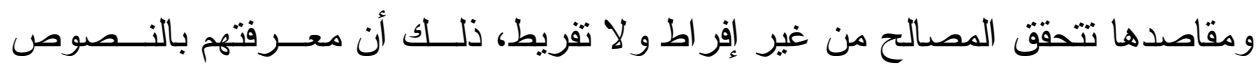
ومقاصد الثريعة تؤهلهم لتمييز صحيح المصاح مفالح من فاسدها.

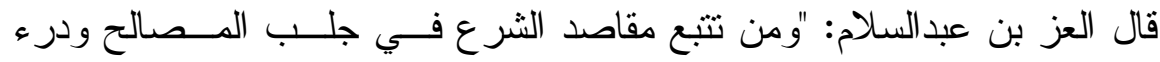

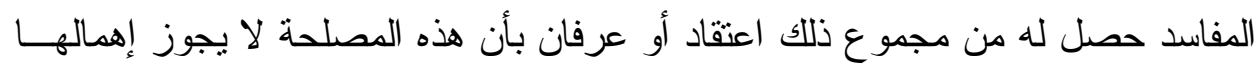

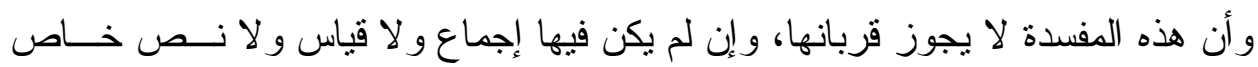

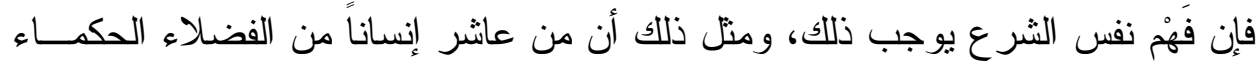

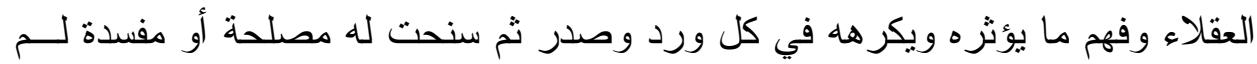

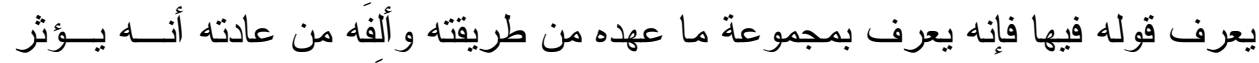

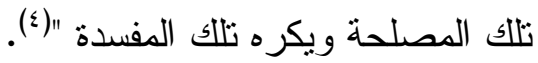

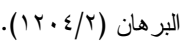

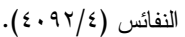

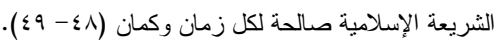

$$
\begin{aligned}
& \text { قو اعد الإحكام (r/. 17). }
\end{aligned}
$$


وأيضاً مما بيين وجه الارتباط بين المصالح المرسلة ومقاصد الثريعة: 1- أن عمدة القائلين بها أن من مقاصد الثريعة رعاية الإدبا المصلحة فإذا عدم النص الدال

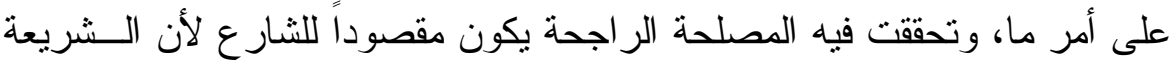
جاءت بجلب المصالح وتحصيلها ودرء المفاسد وتقلبلها. r- أن كلام الأصوليين عن مقاصد الثريعة كان من خلال المصالح المرســلة فبينـــوا

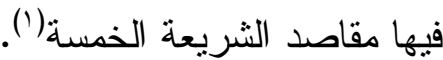
r- ما ذكره الدكتور نور الدين الخادمي: "المصلحة هي المصدر الذي بلاحظ فيه شدة وعمق اتصاله بالمقاصد الثرعية وهي تدور جملة وتفصيلا حول تقدير المــصالح

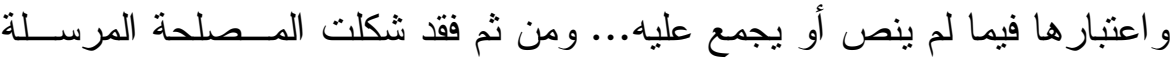

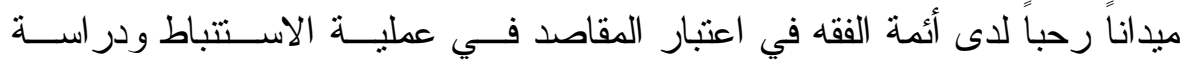

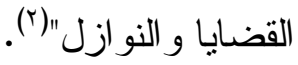

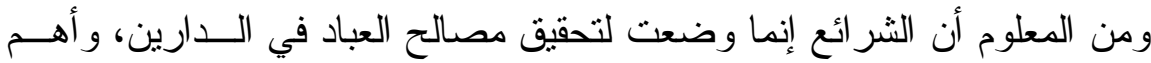

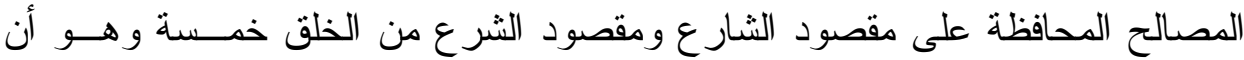

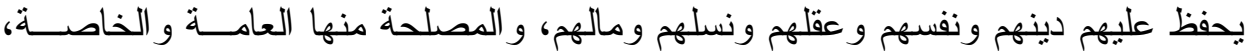

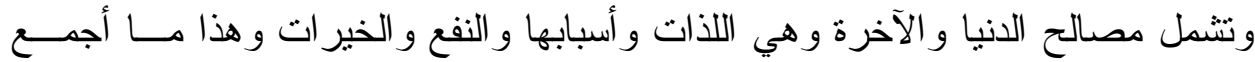
عليه علماء الأصول (r).

\section{الأدلة التي تثبت علاقة المقاصد بالمصلحة كثبرة جداً منها (؛):}

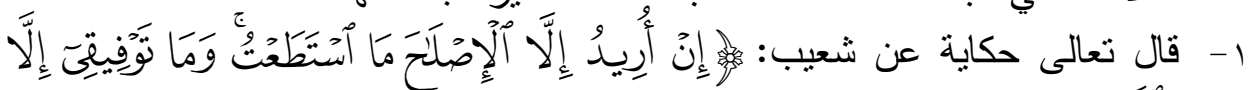
(0)

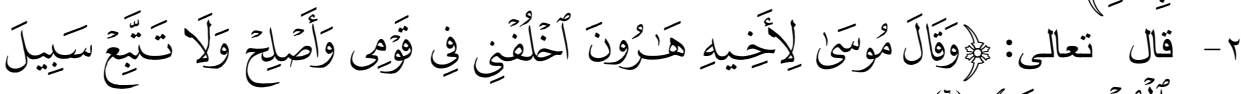

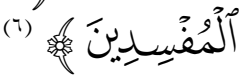

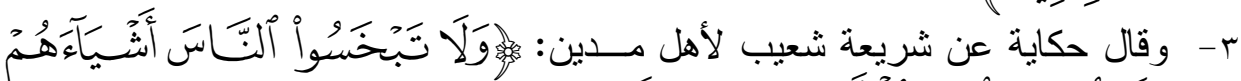

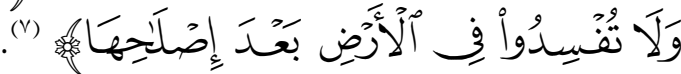

(1) (1) مقاصد الثريعة اليوبي (ب־ه).

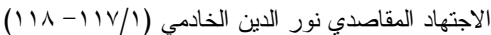

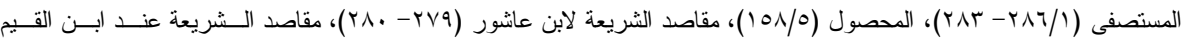

$$
\begin{aligned}
& \text { مقاصد الثريعة لابن عاشور (YVT) } \\
& \text { جزء من الآية (^^) من سورة هود. }
\end{aligned}
$$

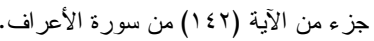

$$
\begin{aligned}
& \text { جزء من الآية (10) من سورة الأعراف. }
\end{aligned}
$$




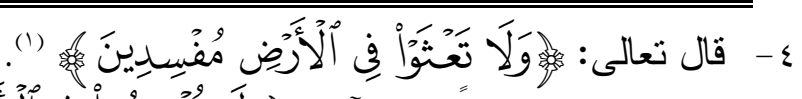

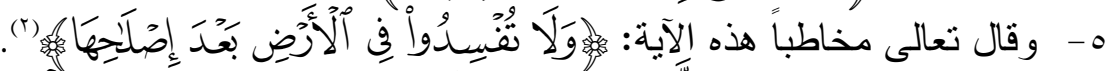

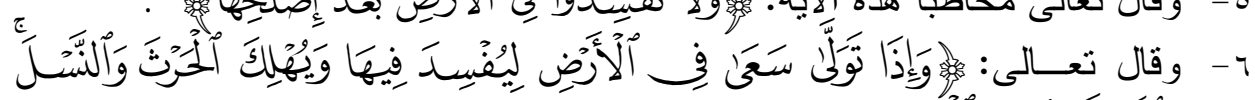

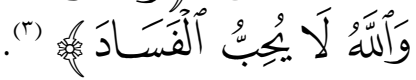

فهذه أدلة كلية صريحة دلت على أن مقصد الثريعة الإصلاح و إز الة الفساد.

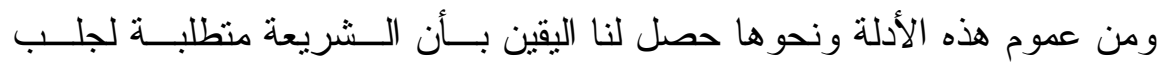
المصالح ودرء المفاسد وتعد هذه قاعدة كلية في الشريعة الثة).

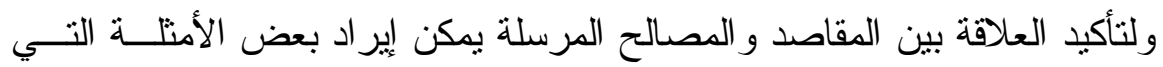
تجلى فيها بوضوح المنهج الاستصلاحي القائم على أساس مر اعاة المقاصد لـأ.

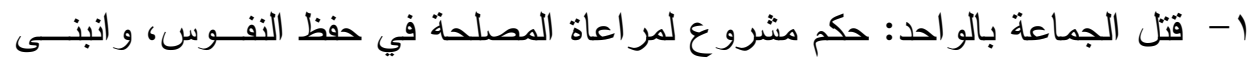

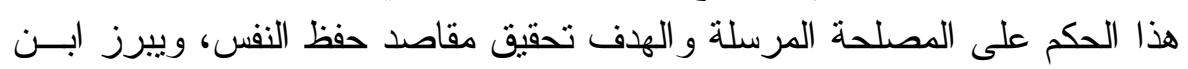

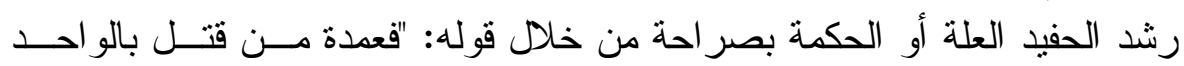

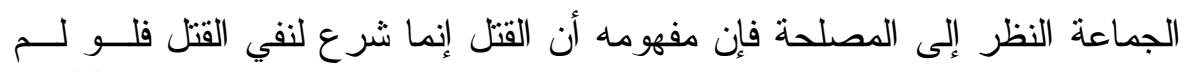

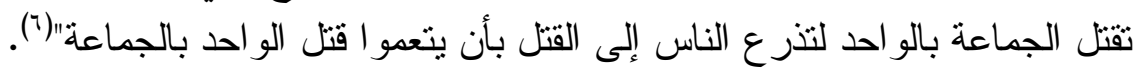

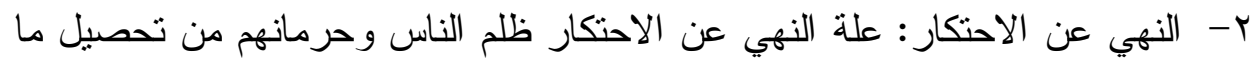

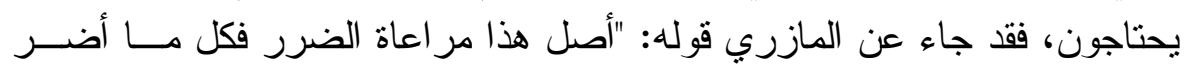

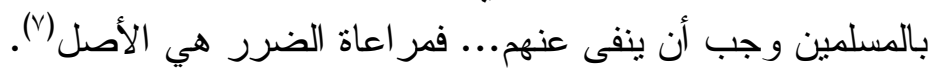

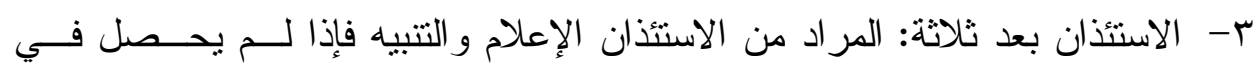

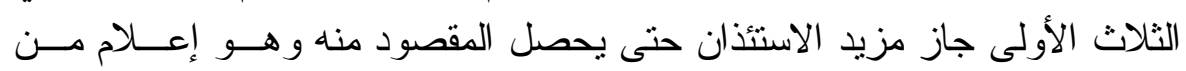

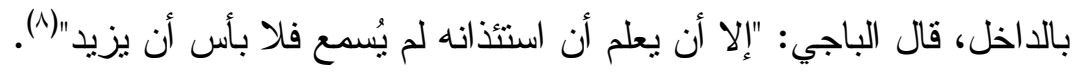

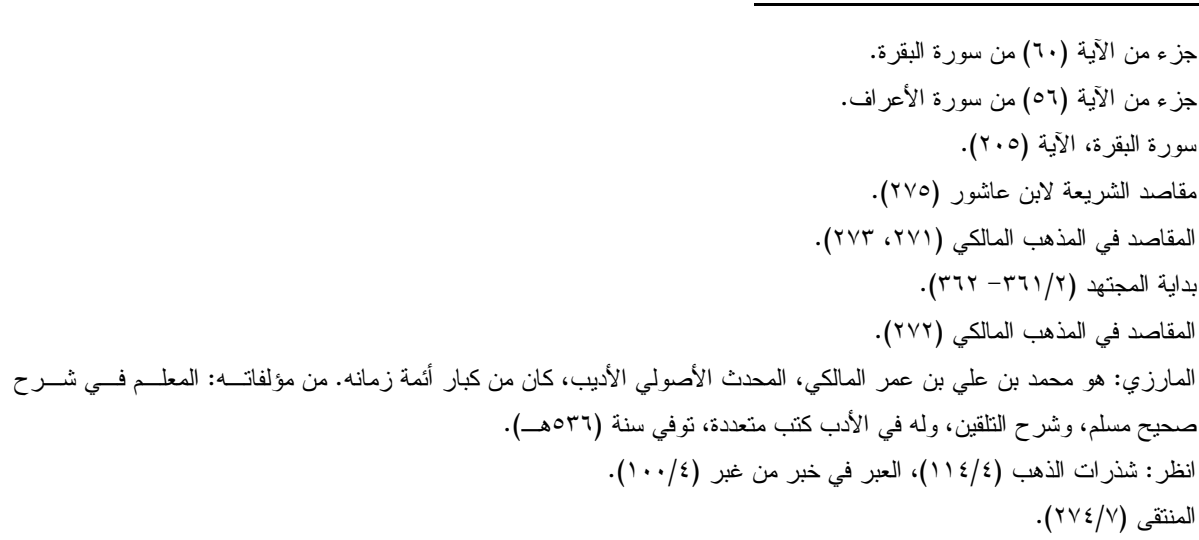

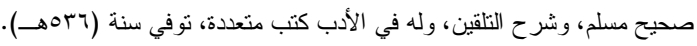

$$
\begin{aligned}
& \text { المنتقى (rV ) }
\end{aligned}
$$


المسألة الثانية: علاقة المقاصد بالاستحسان:

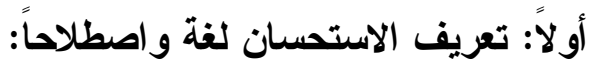
تعريف الاستحسان لغة: تعريف:

استفعال من الحسن، و الحسن ضد القبح ونقيضها، ويطلق على مـــا يميـلـل إليــــ

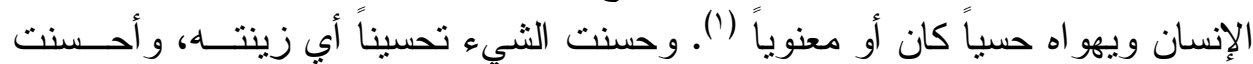
إلبه (r). (r)

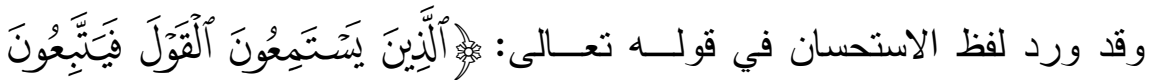

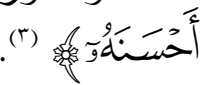

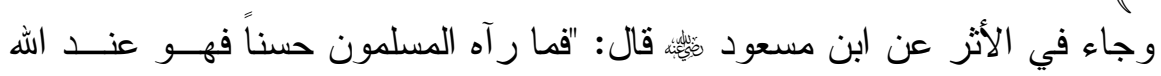

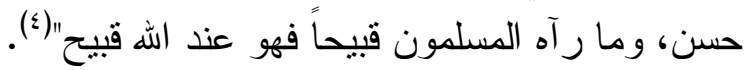
تعريف الاستحسان اصطلاحاً:

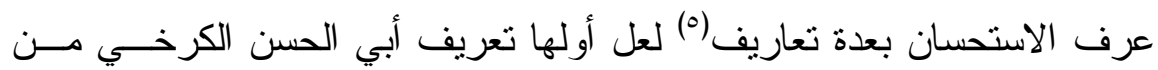

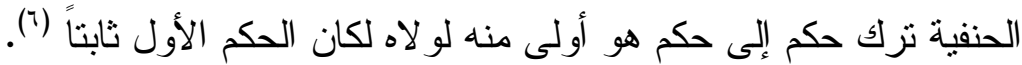
أسباب اختيار تعريف الكرخي:

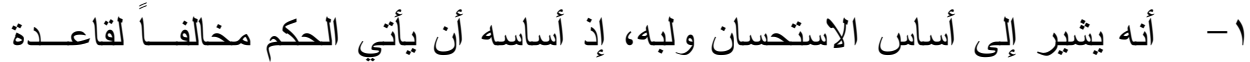

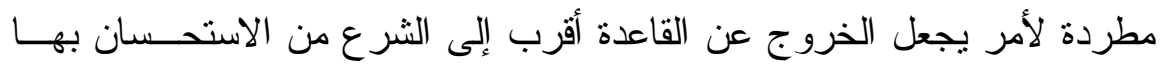
فيكون الاعتماد عليه أقوى استخلال في المسألة من القياس.

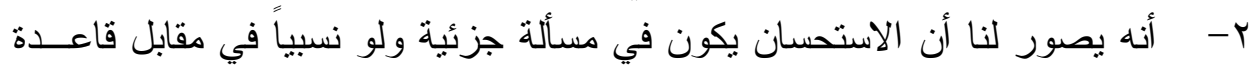

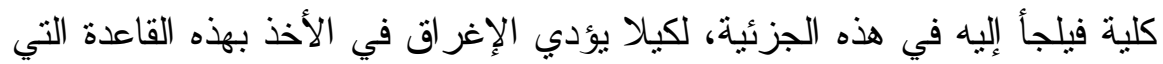

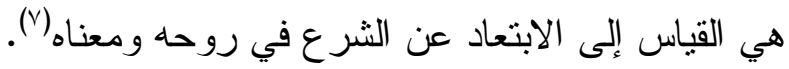

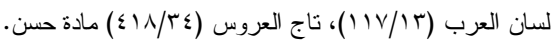

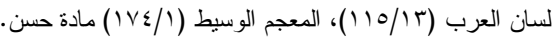

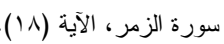

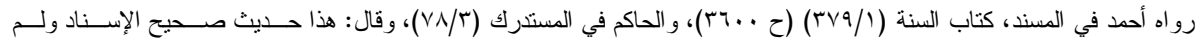

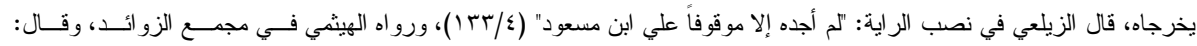

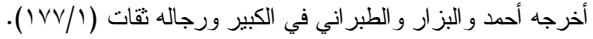

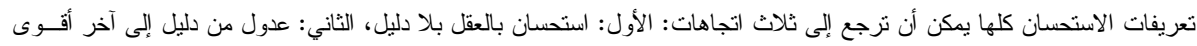

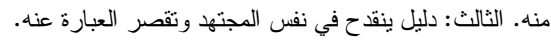

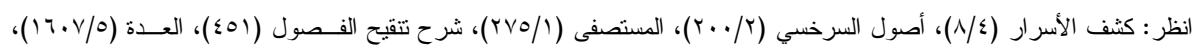

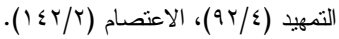

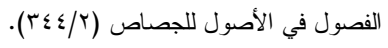

أصول الفقه لأبي زهرة (YTr) (YT). 


\section{ثانياً: حجية الاستحسان:}

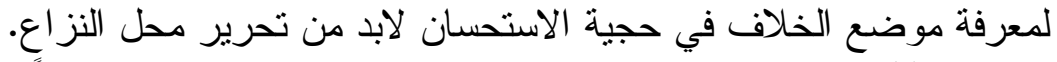

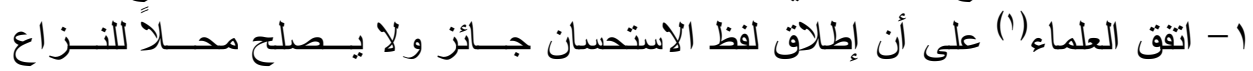

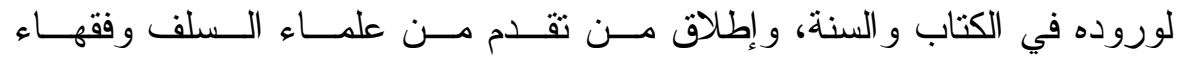

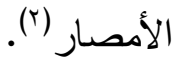

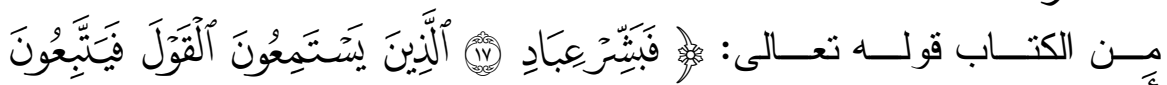

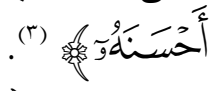

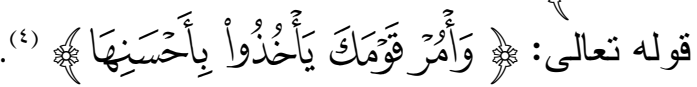

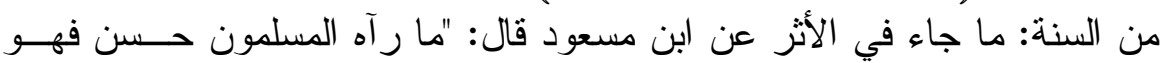
عند الله حسن"(0) من الهن إطلاق من تقلم من السلف: ما ورد عن ماللك أنه قــال: "تـسعة أعـشـار العلــم

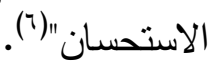

قال الثافعي: "استحسن في المتعة أن تكون ثلاثين در هماً "(Y). r - اختلف العلماء في معنى الاستحسان وحقيقته (^). و إذا كان الأمر كذلك فلابد من التعرف على الأنى معان الاستحسان؛ لنعلم ما يــصلح

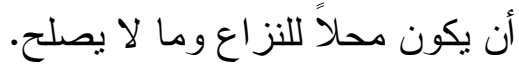
1- ما خرج عن المسألة: إن كان المر اد بالاستحسان هو : القول بما يستحسنه الإنـسـان

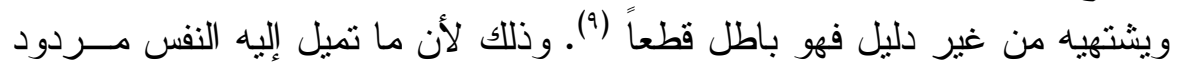

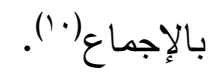

و إن كان المر اد: تخصيص العلة، فهو فاسد(').

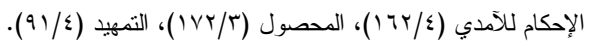

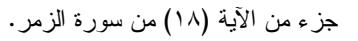

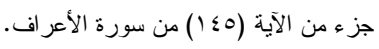

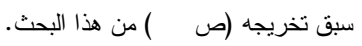
(1) المو افقات (1) (1) ).

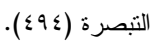

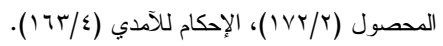

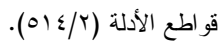

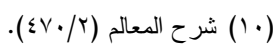




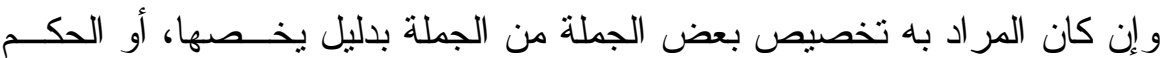

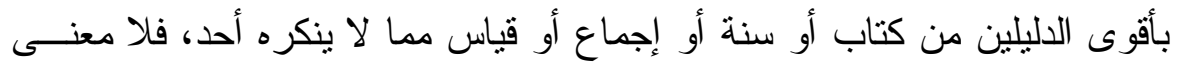

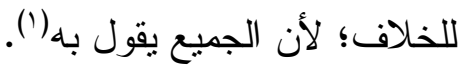

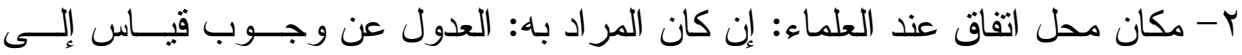

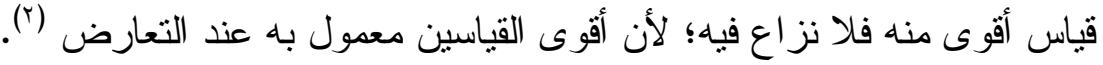

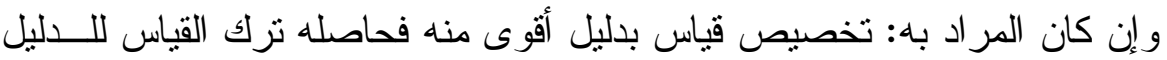
الر اجح، و لا نز اع فيه (").

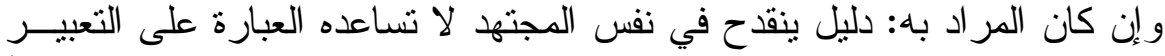

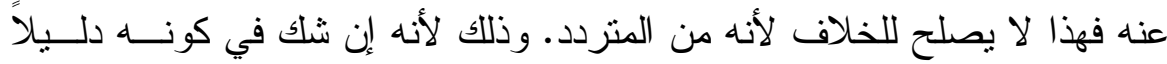

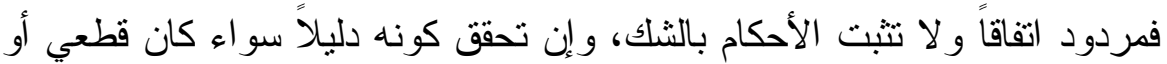
ظني فمعمول به اتفاقًا (). من خلال ما سبق تبين أنه ليس هناك ما يصلح أن يكون صريحاً في كونه محسـلاً للنز اع كاع. r - ما كان موضع اختلاف عند العلماء: مدار الخلاف بين العلهـاء هـــو فــي عــــ

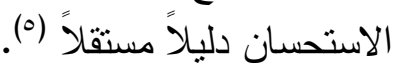
قال ابن السمعاني: "محل النزاع كونه الاعله أصلاً من الأصول تبنى عليه الأحكام "(?).

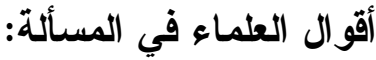

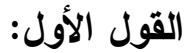

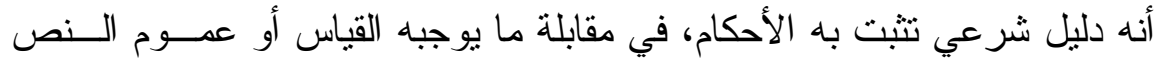

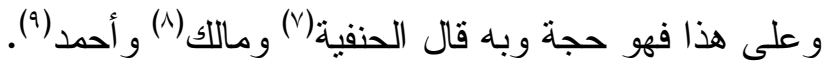

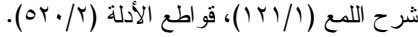

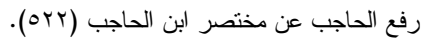

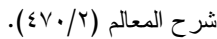

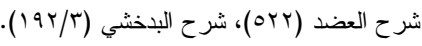

$$
\begin{aligned}
& \text { أصول الفقه لمدكور (17) (17). }
\end{aligned}
$$

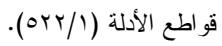

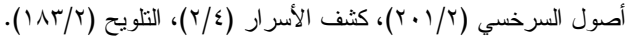

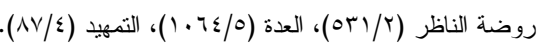

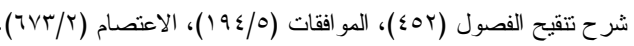


أنه ليس دليل شرعي و إنما هو تذوق وتلذذ وجرأة على النشريع، وهو المنقــول

$$
\text { عن الإمام الثافعي ('). }
$$

1- وذللك لأن القائلين بالاستحسان أر ادو البه العدول في مسألة عن منل ما حكم به في نظائرها إلى خلافه لوجه أقوى أو غير ذلك من العبار ات المفيدة بأن الاستحسـسان

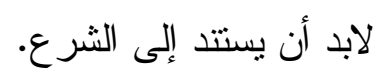

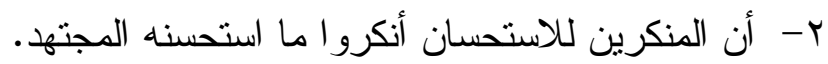

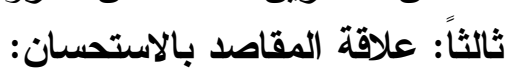
لابد من معرفة أقسام الاستحسان حتى نتعرف علإسئى على علاقة المقاصد بالاستحسان؛ لأن أقسام الاستحسان هي القاعدة التي ننطلق منها لمعرفة العلاقة.

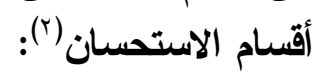

ينقسم الاستحسان بحسب الدليل الذي يثبت به إلى خمسة أقسام:

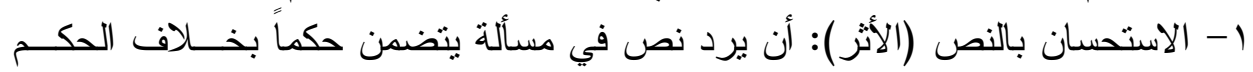

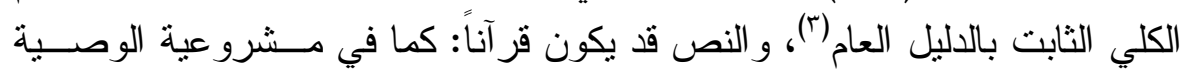

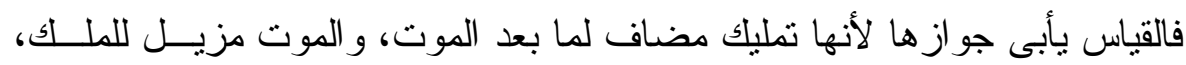

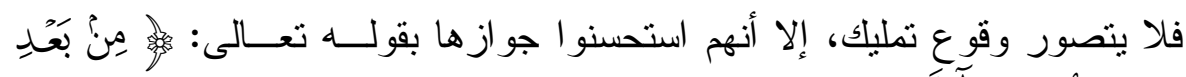

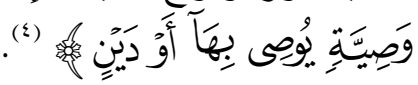

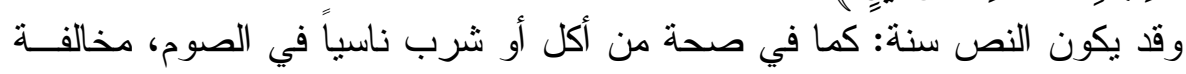

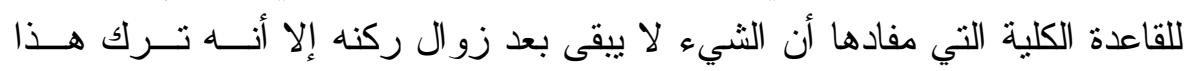

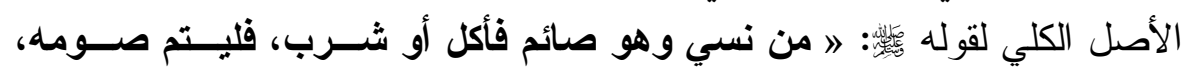

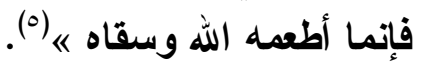

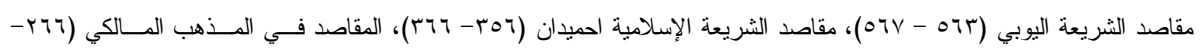

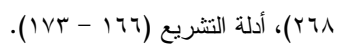

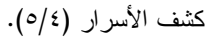

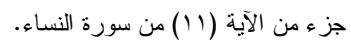

أخرجه البخاري، كتاب الصوم، باب إذا أكل أو شرب ناسياً (ح ستو (1) (1 (100). 
ץ- الاستحسان بالإجماع: وهو أن يقع الإجماع على خلاف قاعـدة عامــة أو قيــاس

كلي (')

مثاله: عقد الاستصناع، فالقياس يقتضي عدم جو ازه لأنه بيع معدوم، ولكن أجيز العمل

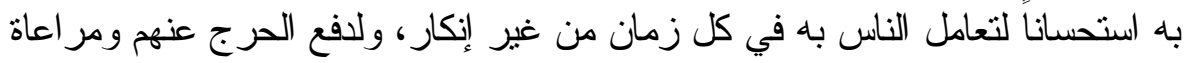
ل لحاجاتهم

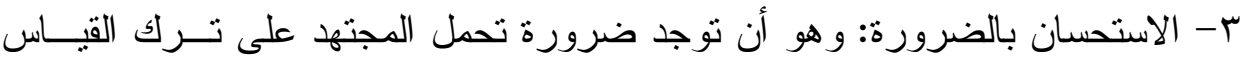
و الأخذ بمقتضى الضرورة أو الحاجة (؟).

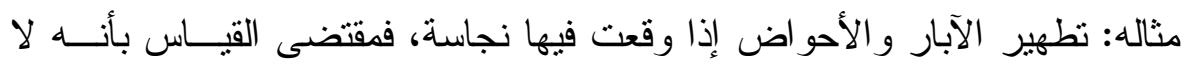
يمكن تطهير ها بنزح الماء كله أو بعضيه.

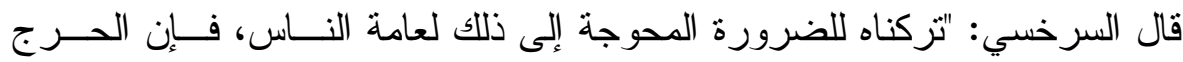

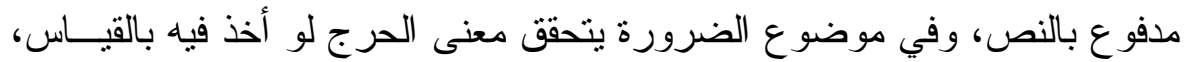

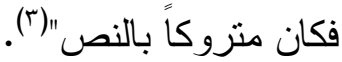
ع - الاستحسان بالعرف: وهو العدول عن مقتضى القياس إلى حكم آخر يخالفه لجريان

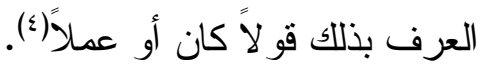
مثاله: استئجار المرضعة بطعامها وكسوتها فإن الأصل استئجار المرضع بـأبـأجرة

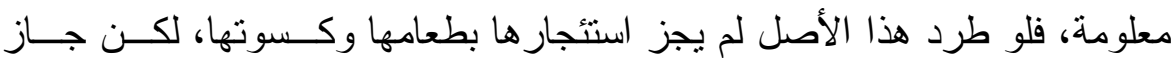

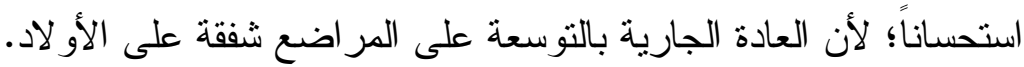

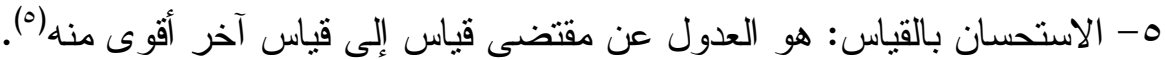

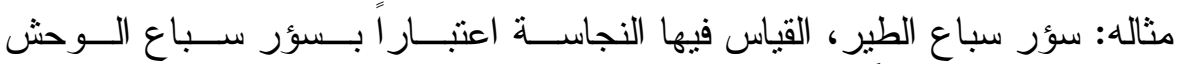

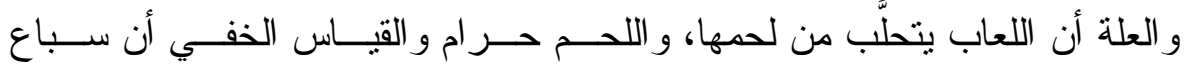

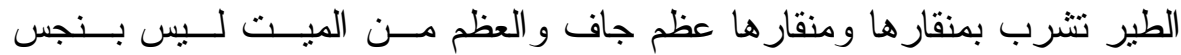

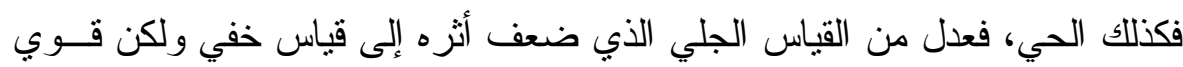
أثزه.

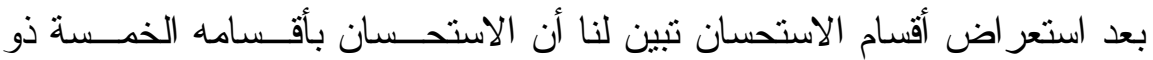
علاقة وثيقة وارتباط قوي بالمقاصد الثر عية؛ لأنه عبارة عن عدول من دليل إلى آخــر

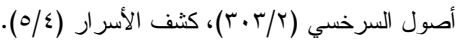

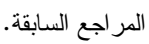

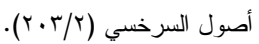

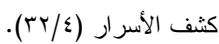

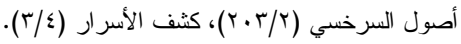


هو أقوى منه فكأنه يعود إلى الأدلة الأخرى من كتاب وسنة و إجماع وقياس وغير ذلك،

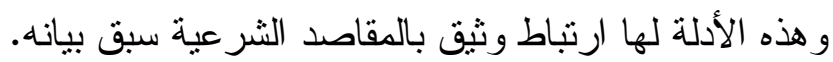

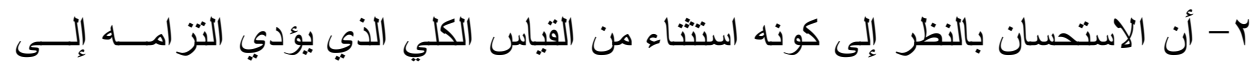

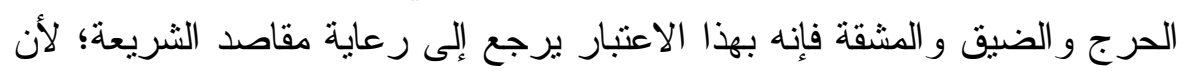

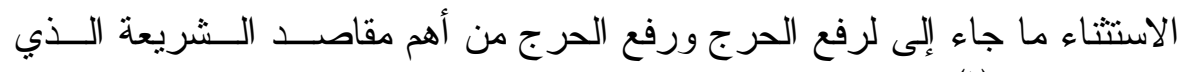
تسعى لتحقيقه (').

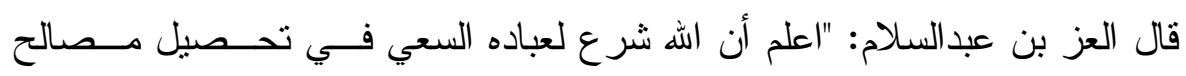

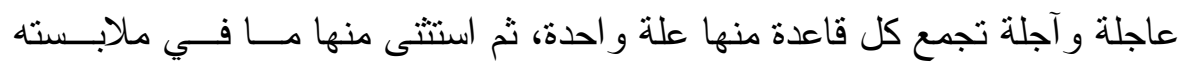

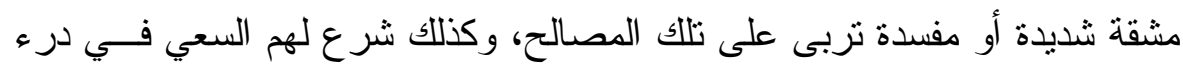

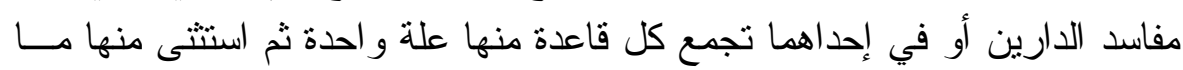

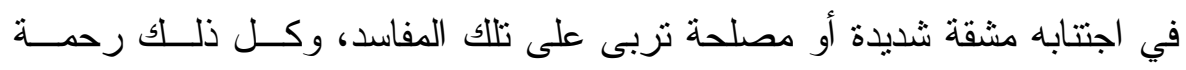

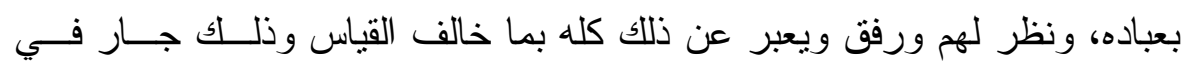

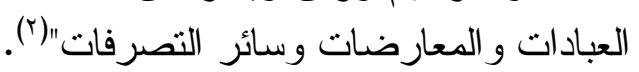
فترك القياس في بعض الحالات ليس راجعاً إلى الهوى و التشهي و إنما لكون الأخذ

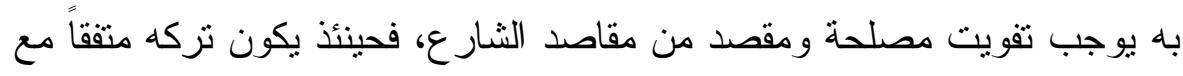
مقاصد الشريعة، وهذا ما ذكره السرخسي وغيره من العلماء كما سبق.

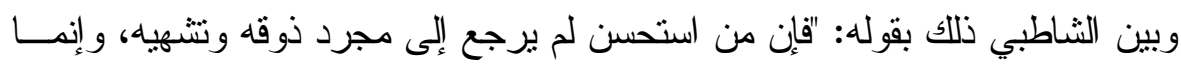

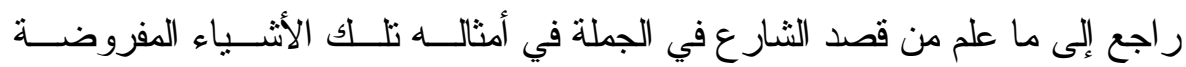

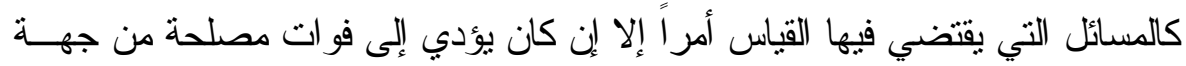
أخرى، أو جلب مفسدة كذلك" (َّ).

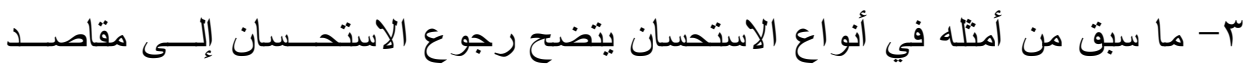

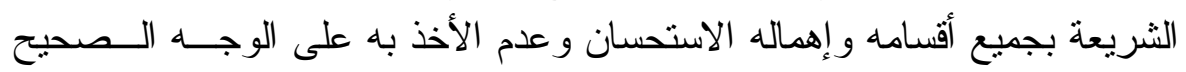

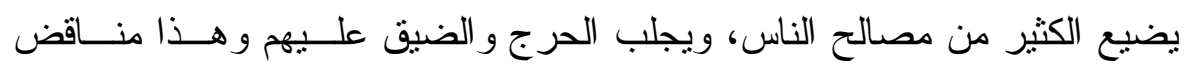
لمقصود الثريعة من التيسير والتوسعة عليهم (؛).

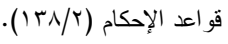

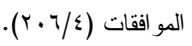

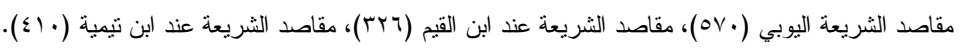


ع - أن النظر في مآلات الأفعال معتبر مقصود شرعاًً)'، وقد ذكر الثاطبي هذه القاعدة

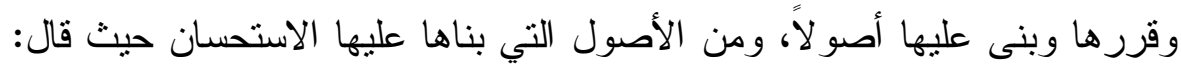
"ومما ينبني على هذا قاعدة الاستحسان". ووجه دخول الاستحسان تحت قاعدة المآلات أن التزام الدليل العــام أو القاعــدة

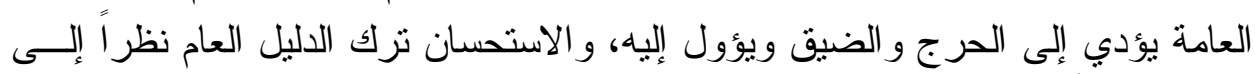

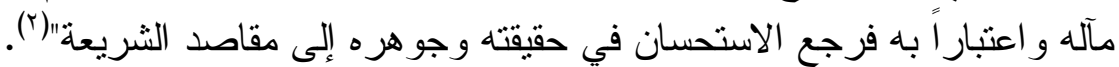

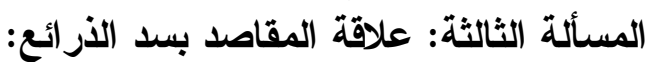
أولاً: تعريف سد الأرائع لغة واصطلاحاً:

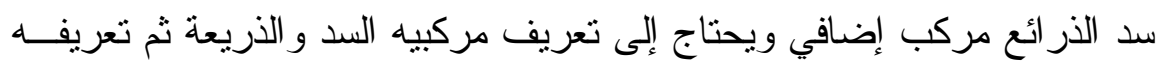
على أنه لقب لقاعدة سد الذرائع. تعريف السد لغة: السين و الدال أصل و احد(")، و هو يدل على ردم شيء، و والــسد

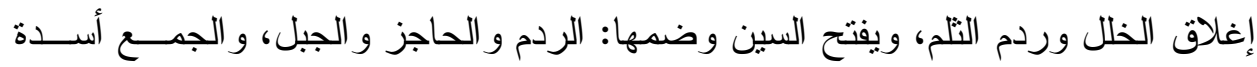
وسدود (๕) وكل حاجز بين الثيائين سد، ومن ذلك السديد وذو السداد -أي الاستقامة- كأنـــه

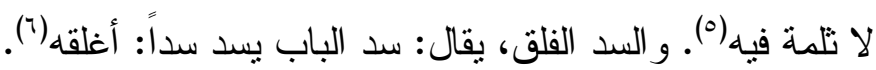

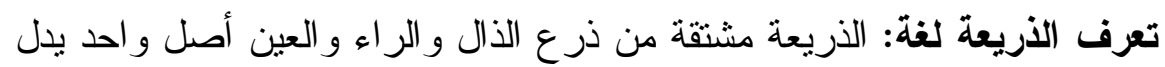

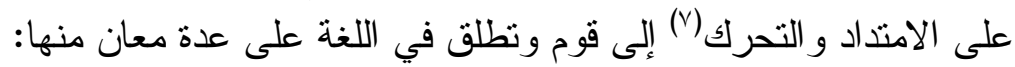

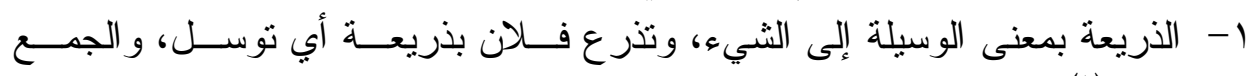

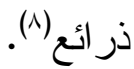
r- الذريعة بمعنى الرديئة وهي الناقة التي يستتر بها الر امي ليرمي الصيد(9).

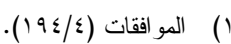

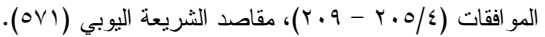

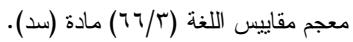

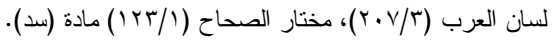

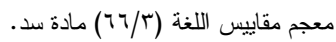

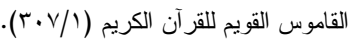

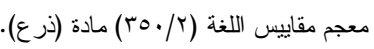

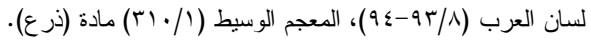

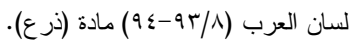


تعريف كلمة سد اصطلاحاً: لكلمة السد معان كثيرة كما سبق، و لا يعرف المــر اد

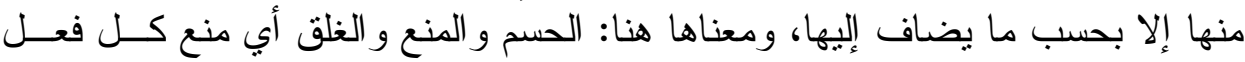
يؤدي إلى مفسدة.

قال القر افي: سد الذر ائع معناه: حسم مادة وسائل الفساد دفعاً لها"(').

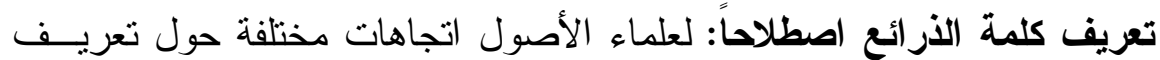

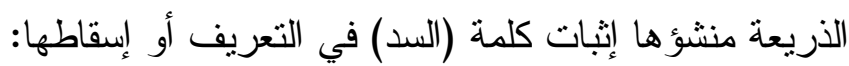

1- تعريف الذريعة بإضافة كلمة السد أب المعنى اللقبي أو الخاص وهئ وهو الأكثر (؟).

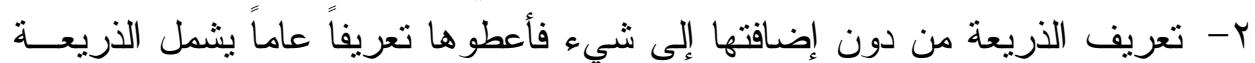

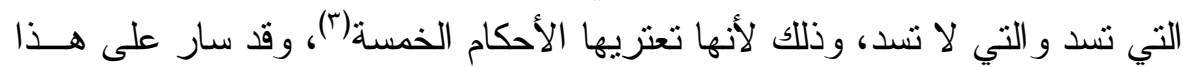

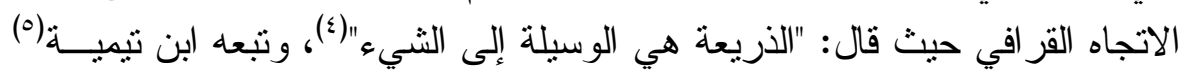

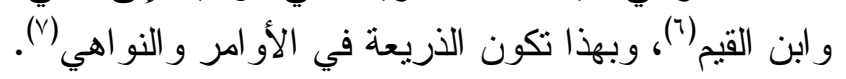

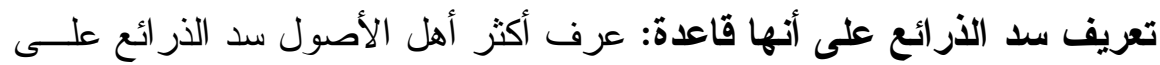

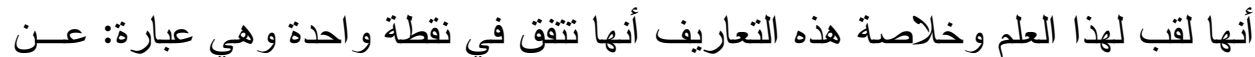
فعل مباح ينوصل به إلى فعل محظور (^).

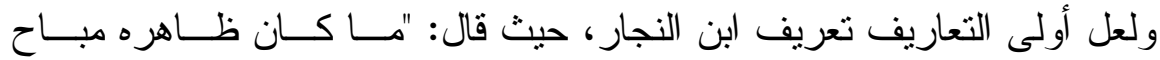

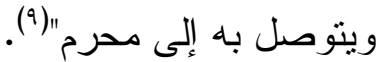

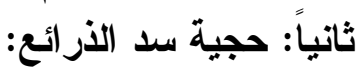
لعله لا يتبين محل النزاع إلا بعرض موقف كل مذهب من أقسام سد الذرائع.

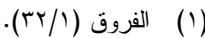

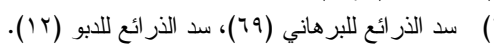

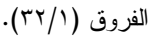

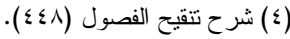

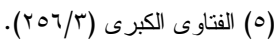

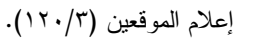

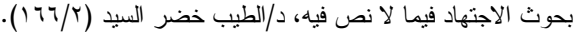

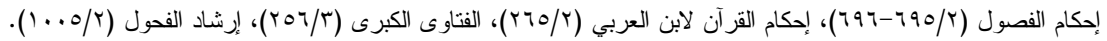

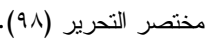

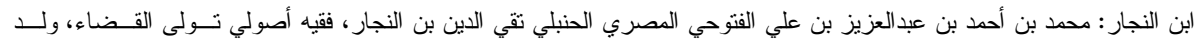

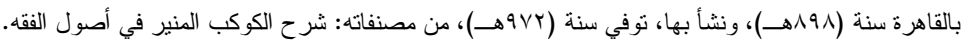

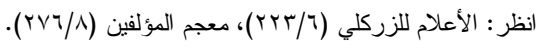




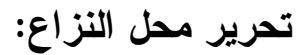

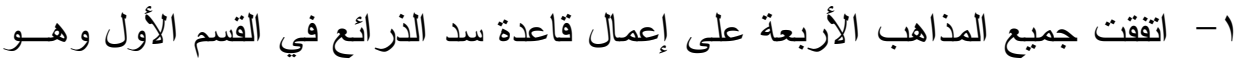

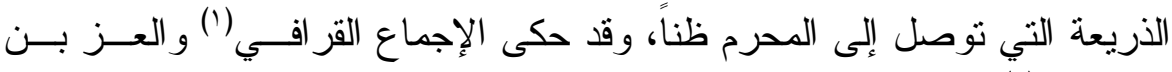

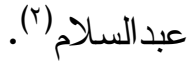

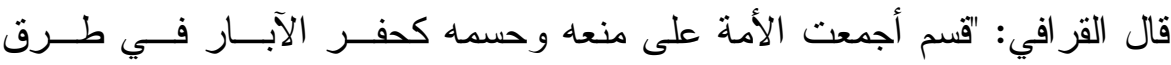

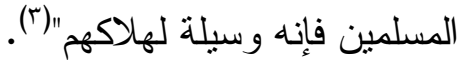

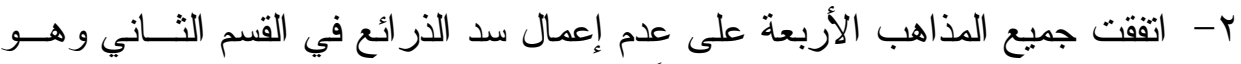

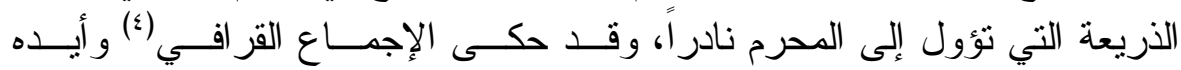

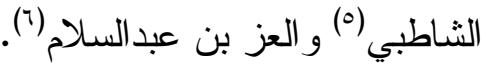
قال القر افي: "قسم أجمعت الأمة على عدم منعه و أنه ذريعــة لا تـسد ووســيلة لا

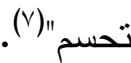
ب- اختلف العلماء في القسم الثالث وهو الذريعة التي توصل إلى المفـسدة كثيــراً لا لا غالباً و لا نادر اً على قولين العين

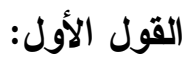

القول بسد الذرائع في هذا القسم سو اء ظهر قصد الفساد أو لم يظهر ذهب إليـــه

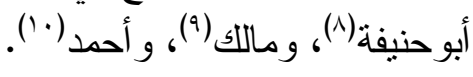

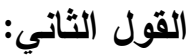

القول بعدم سد الذرائع في هذا القسم بل لابد من النظر إلى القصد فيحسن الظــنـن

بمن لم يظهر منه قصد المنع، وذهب إليه الثافعي (')".

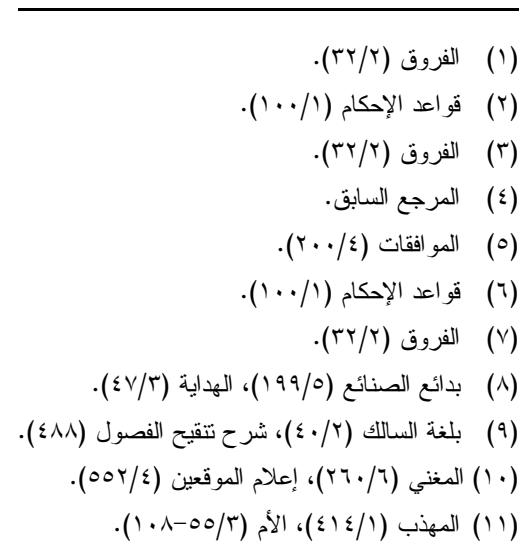


قال الثافعي في الأم: "وليست تقبد البيوع أبداً إلا بالعقد، فإذا عقد عقداً صــحيحاً

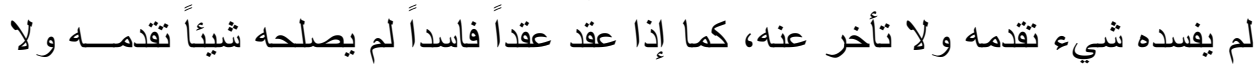

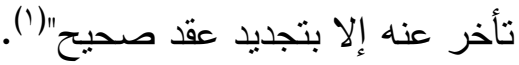

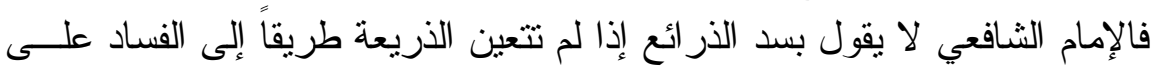

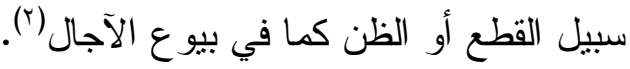

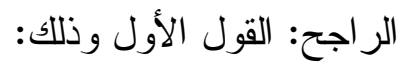

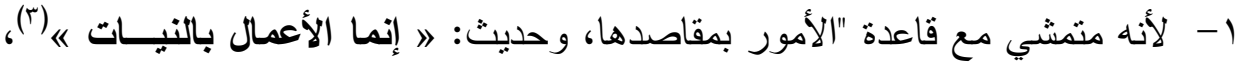

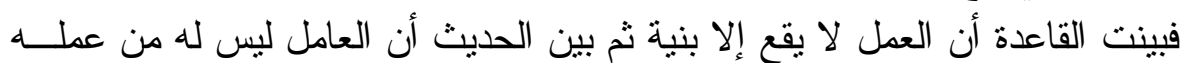

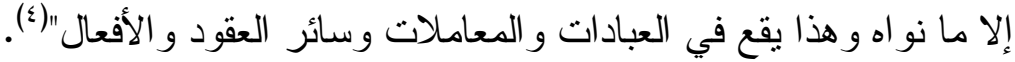

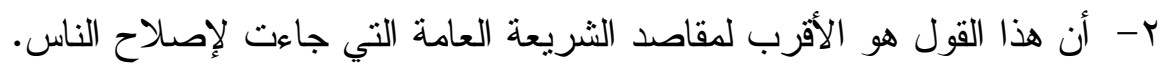

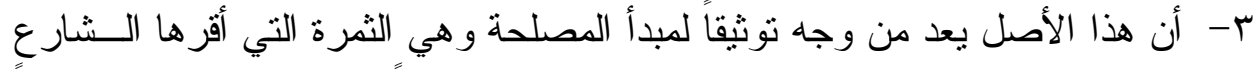
فجلبها مطلوب فكل ما يؤدي إلى مصلحة يكون مطلوباً بقر توصيله إليها قطعـا

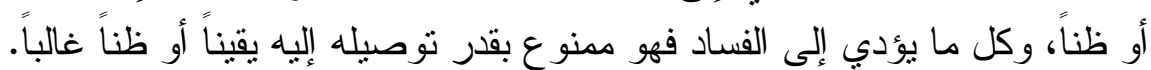

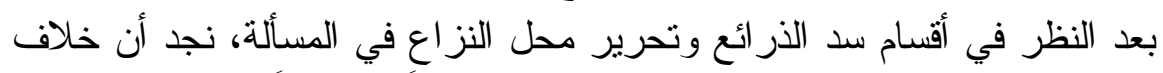

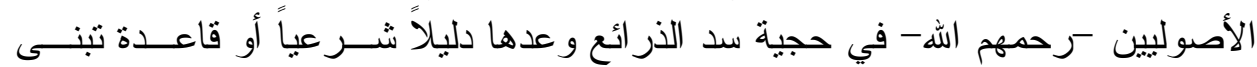
عليها الأحكام الثرعية ينحصر في قولين رئيسيين:

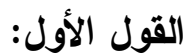

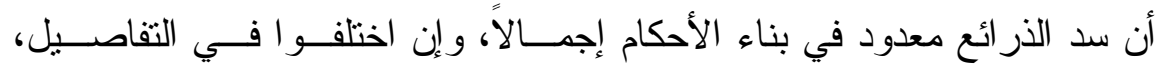

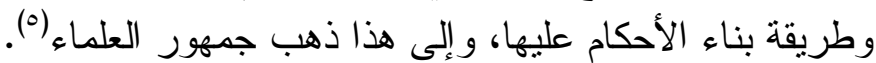

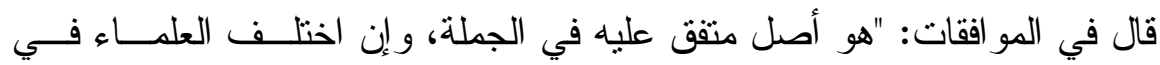
تفاصيله فليس الخلاف في بعض الفروع يبطل دعوى الإجماع في الجملة"(ج).

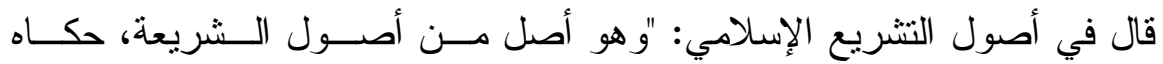

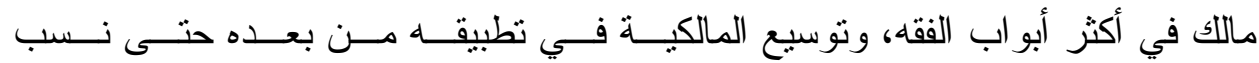


إليهم، و الحق أن غيرهم لا يخالفهم في أصل القاعدة وإن خالفهم في تطبيقها في بعـض

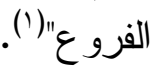

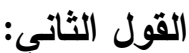

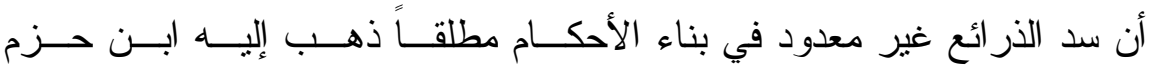
و الظاهرية(†)؛ لأنهم يرون أنه من أبو اب الاجتهاد بالر أبي و الظاهرية يسدونه مطلقاً.

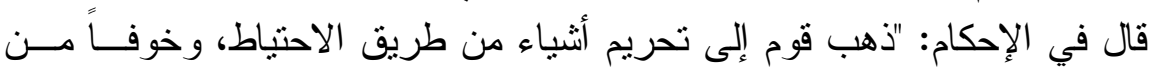

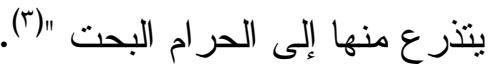

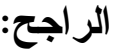

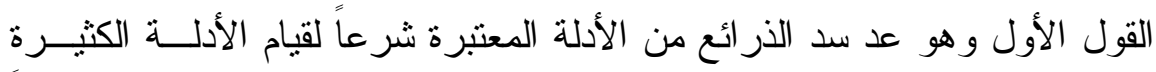

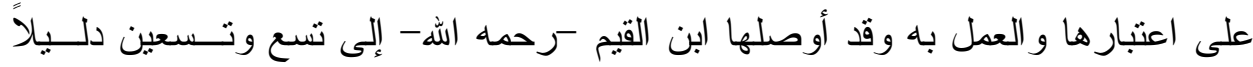

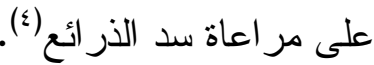

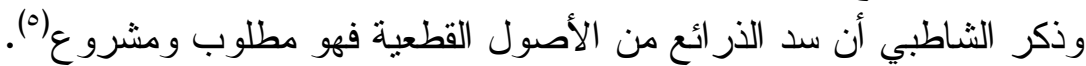

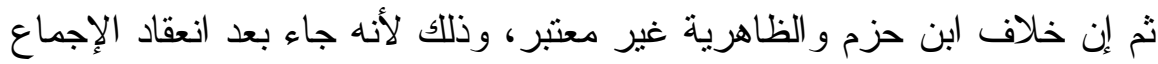

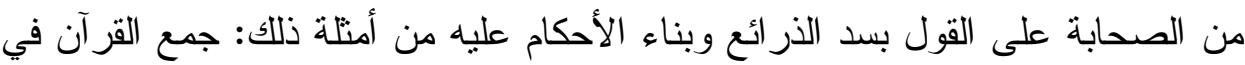

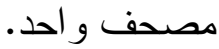

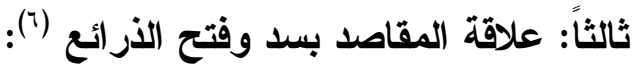

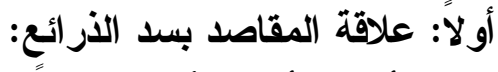

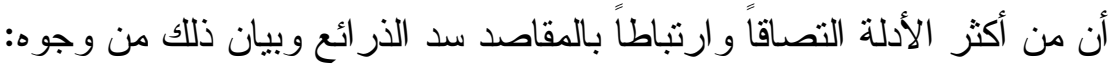

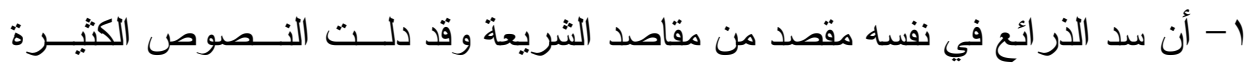

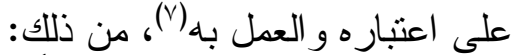

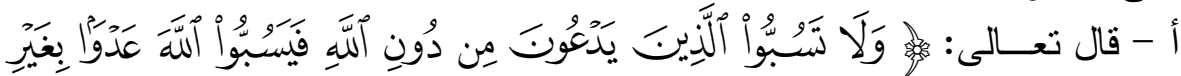
(ㅅ)

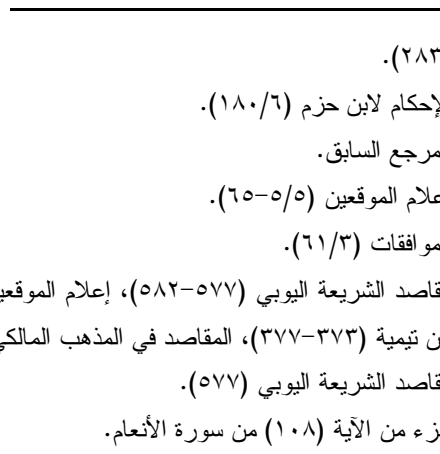

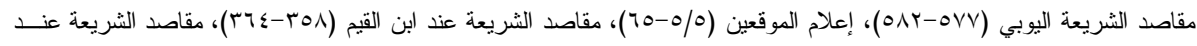

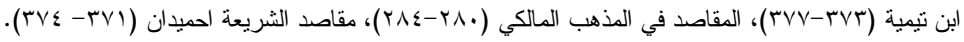




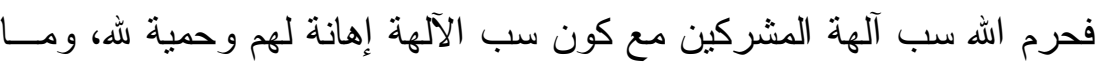
ذللك إلا لكونه ذريعة إلى سبهم لله تعالى، وكان مصلحة ترك مسبته ســـــانه أرجح من مصلحة سبنا لآلهتهم. قال ابن القيم: "وهذا كالتصريح على المنع من الجائز لئلا يكون سبياً في فعل لالّه

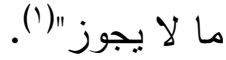

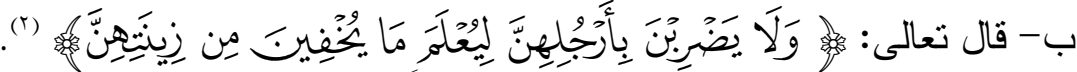

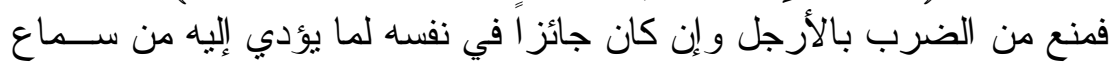

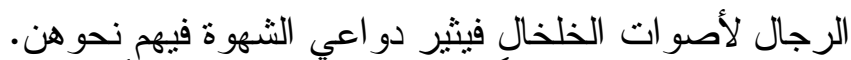

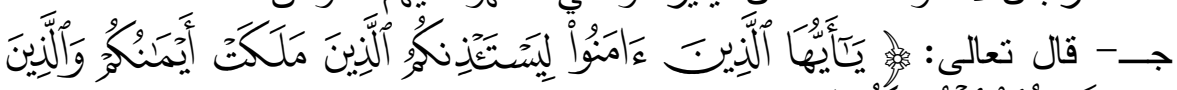

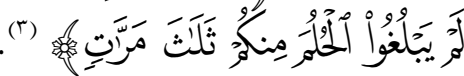

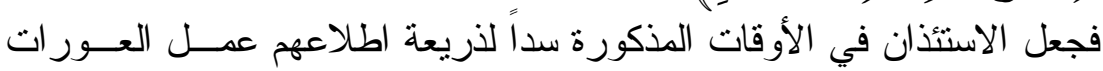
حين وضع الثياب ونحوه. د - قوله عليه الصلاة و السلام: 》 من الكبائر شتم الرجل و الديه، قالوا: يا رسول

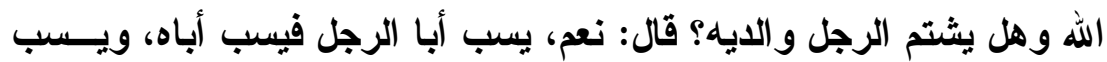

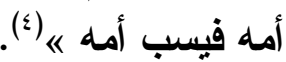

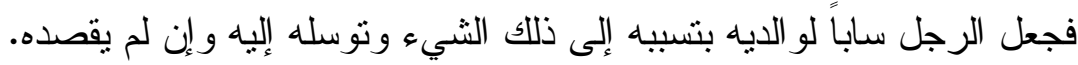

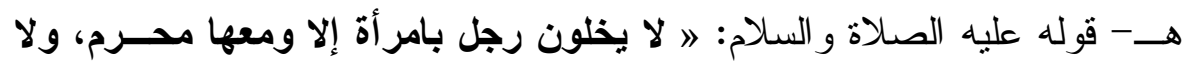

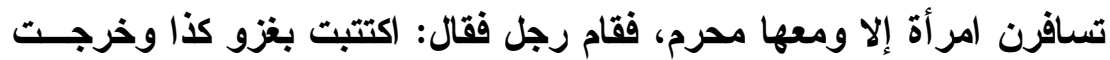

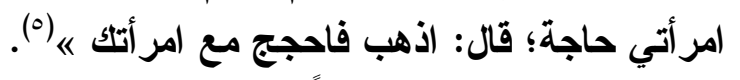

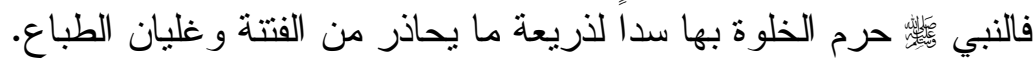

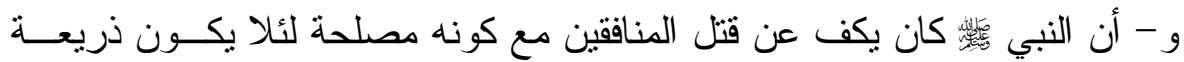

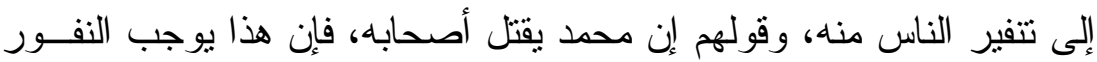
من الإسلام، ومفسدة التتفير أكبر من مفسدة تزك قت قتلهم.

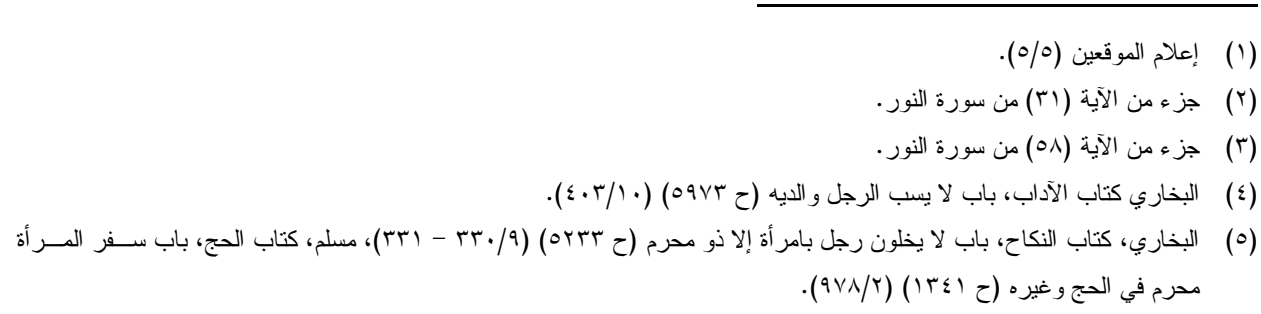




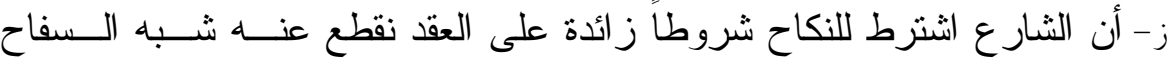

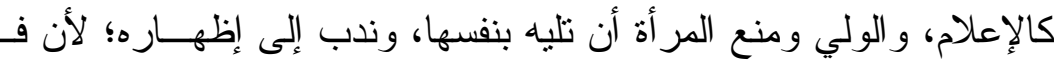

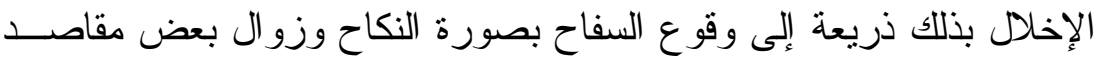

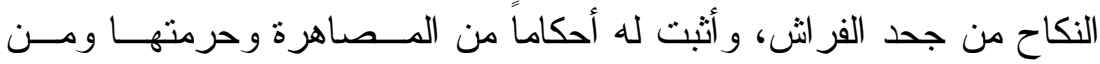

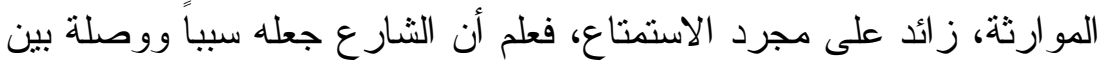

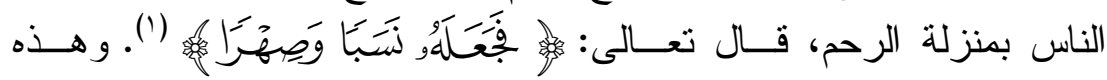

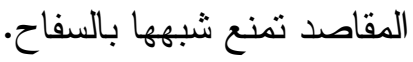

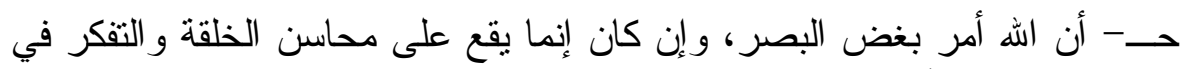

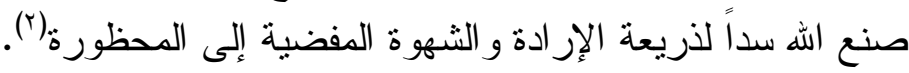

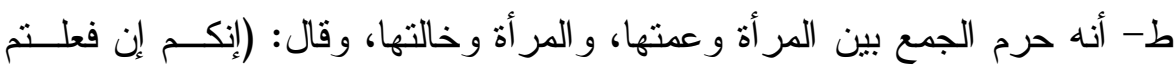

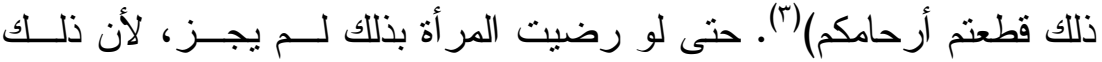

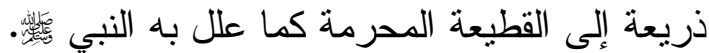

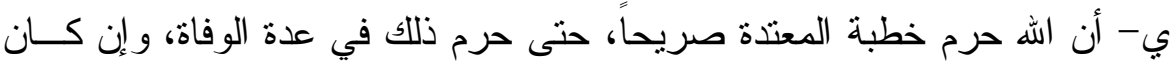

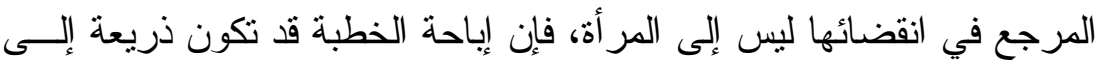

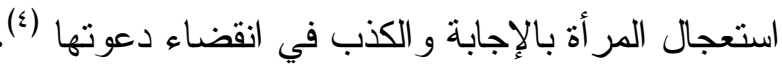

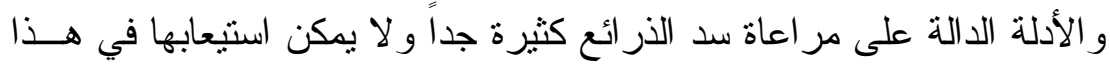

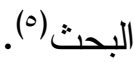

r- أن في سد الذرائع حماية لمقاصد الثريعة، ونوثيقاً للأصل العام الذي قامــت عليــــ الثريعة من جلب المصالح ودرء المفاسد.

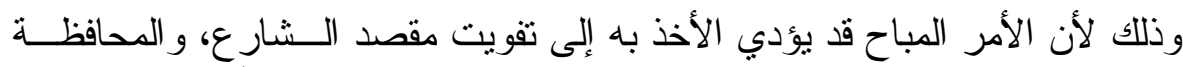

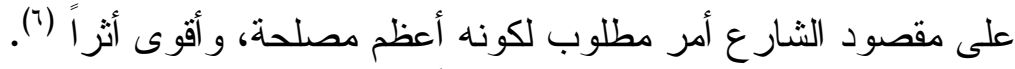

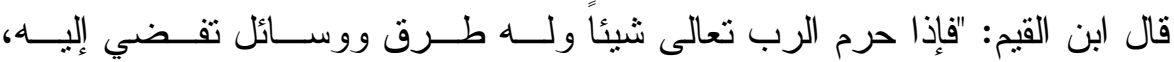

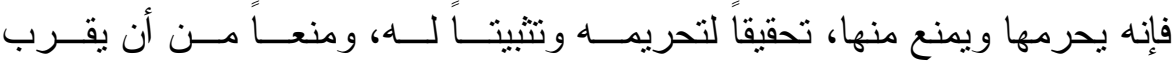

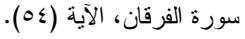

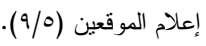

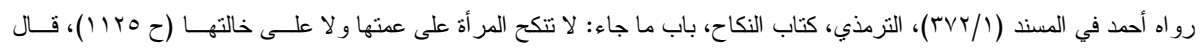

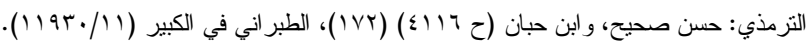

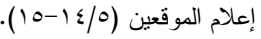

مقاصد الشريعة اليوبي (OV9) (OV9).

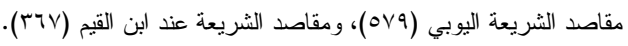


حماه ولو أباح الوسائل و الذر ائع المفضية إليه لكان ذلك نقضاً للتحــريم و إغــر اءً للنفوس بـه.

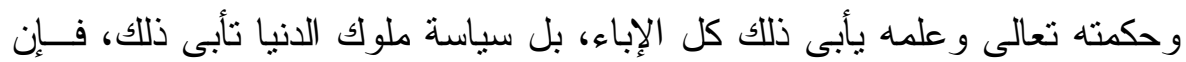

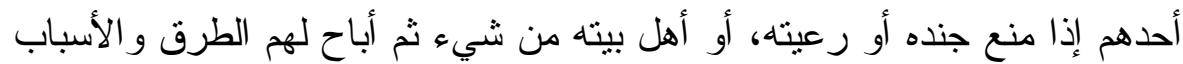

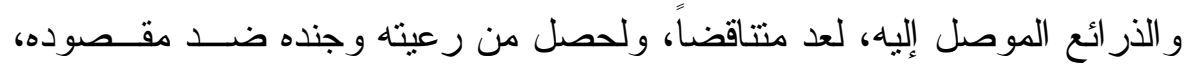

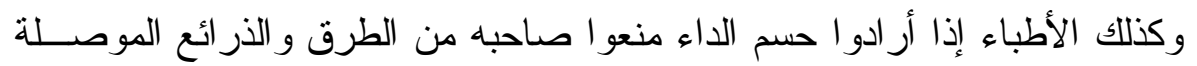

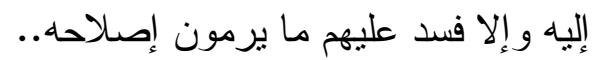

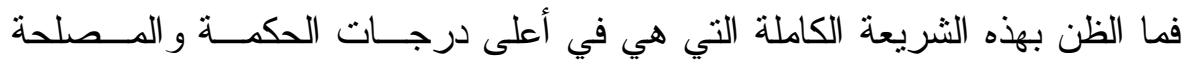

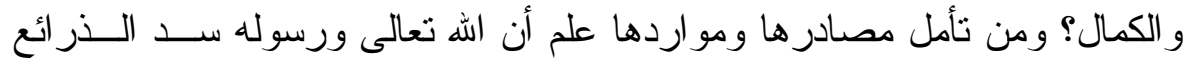

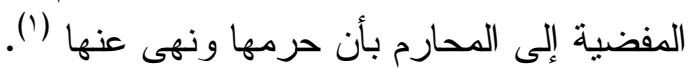

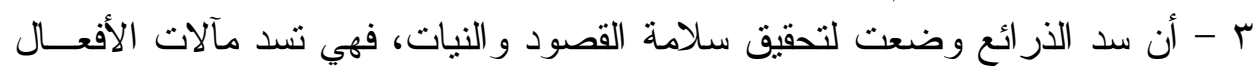

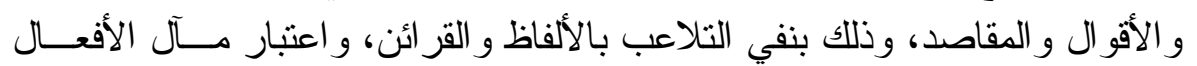
من المقاصد المهمة في الثريعة.

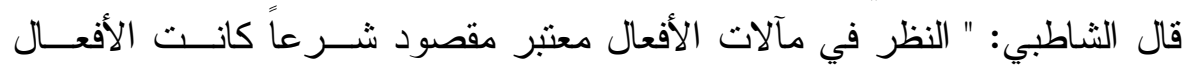

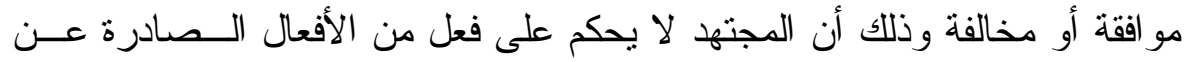

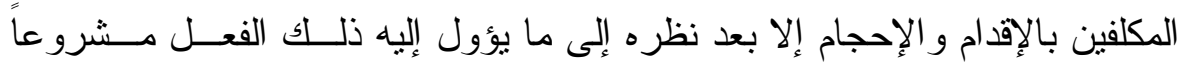

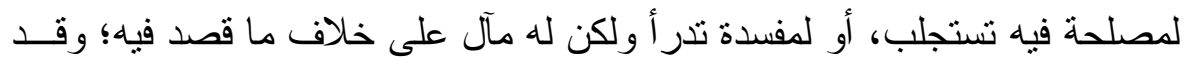

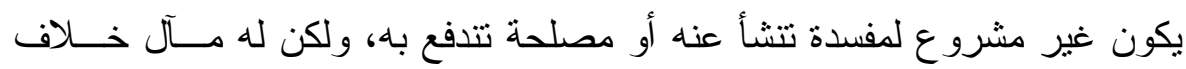

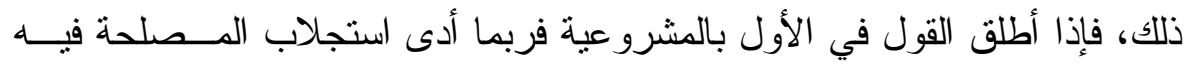

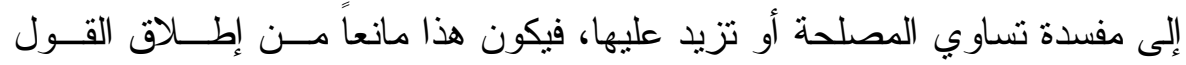
بالمشرو عية.

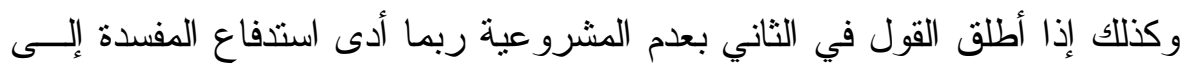

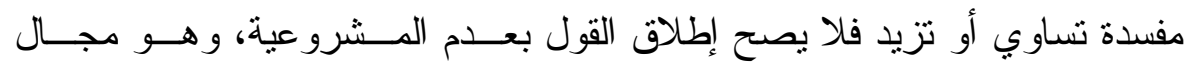

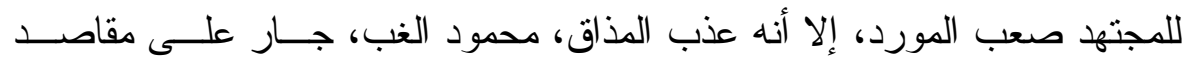
الشريعة(؟). وقد و افقه ابن تيمية في ذلك.

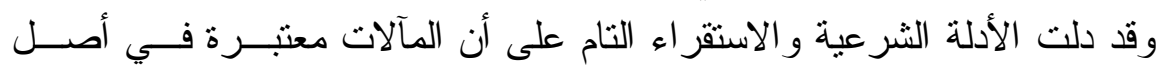
المشرو عية من ذلك: 


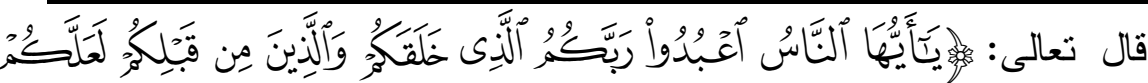

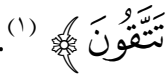

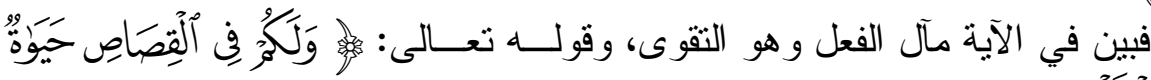

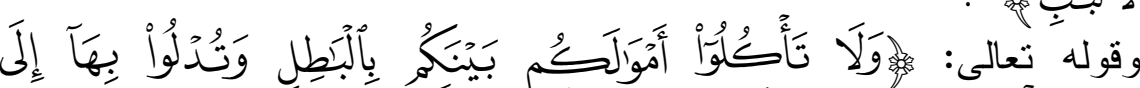

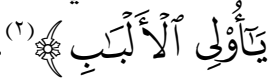

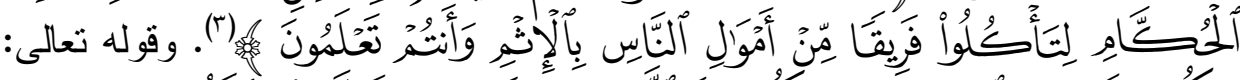
(s)

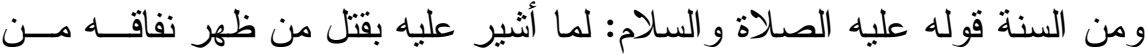

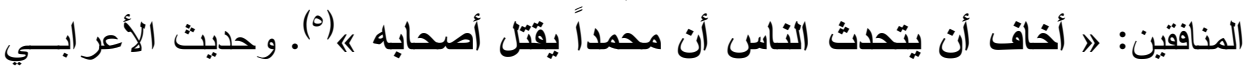

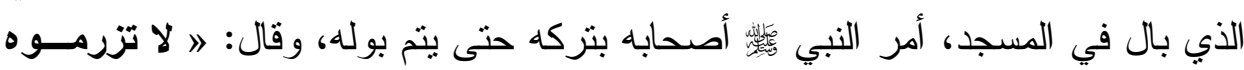

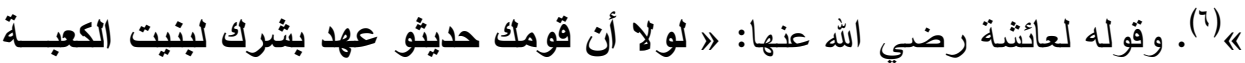

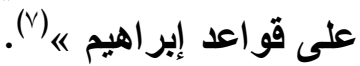

وبيان ارتباط سد الذرائع بهذا المقصد أن المجتهد ينظر إلى مآل الأفعــال ومــا تتنهي إليه في جملتها، فإذا كانت تتحو نحو المصالح التي هي المقاصد و الغايات، كانت مطلوبة بمقدار يناسب طلب هذه المقاصد، وإن كانت مآلاتها تتحو نحو المفاسد، فإنهــا

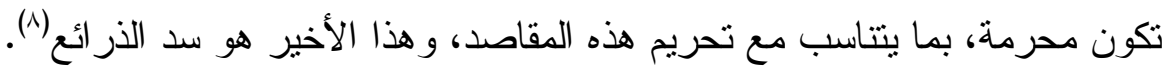

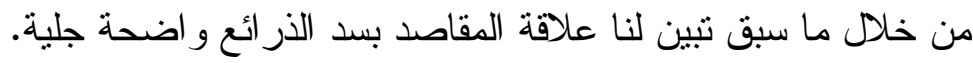

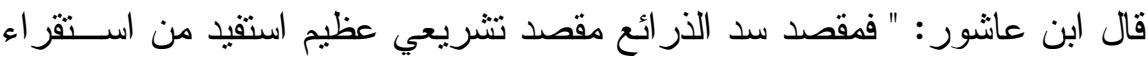

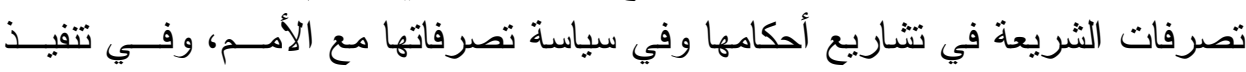
مقاصدها"(9).

(1) سورة البقرة، الآية (Y)(Y).

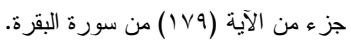

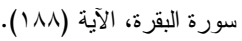

سورة البقرة، الآية (Tی1).

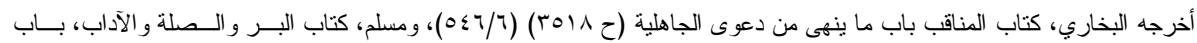

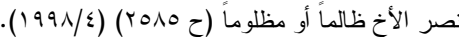

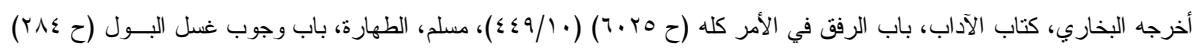

( )

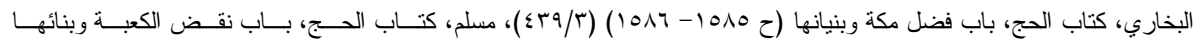

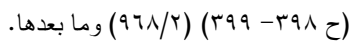

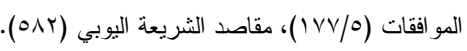

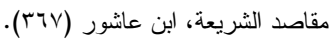


ثانياً: علاقة المقاصد بفتح الذرائع:

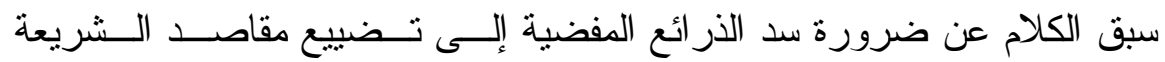

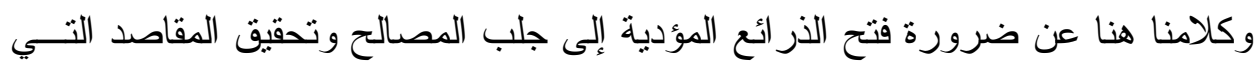

لا تحصل إلا بها.

قال القر افي: "اعلم أن الذريعة كما يجب سدها يجب فتحها ويكره ويندب وييــاح

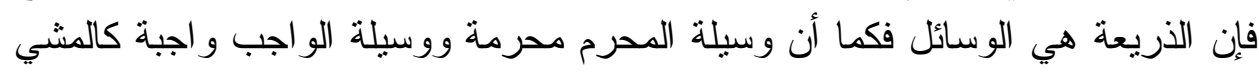
للجمعة و الحج.

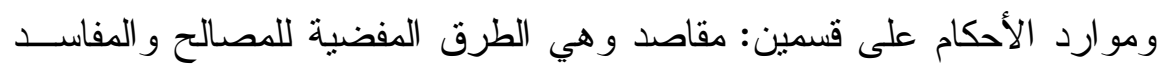

في أنفسها.

ووسائل وهي الطرق المفضية إليها وحكمها كحمم ما أفضت إليه من تحــريم أو

تحليل" (1) - (1)

قال ابن القيم: "لما كانت المقاصد لا يتوصل إليها إلا بأسباب وطرق تقضي إليها

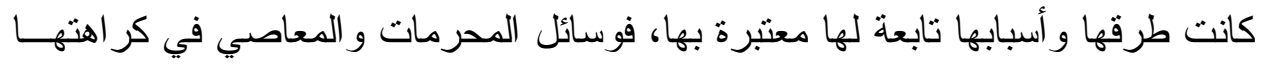

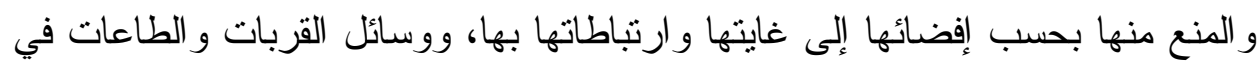

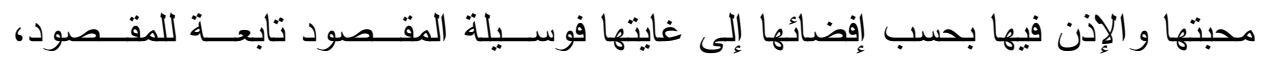
وكلاهما مقصود لكنه مقصود قصد الغايات، ومقصود قصد الوسائل"(r).

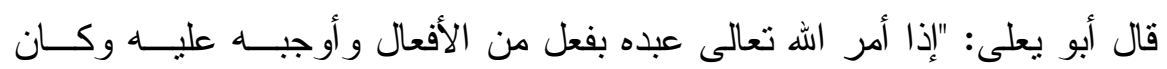

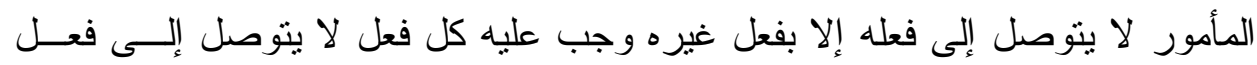

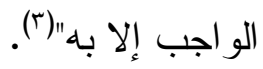

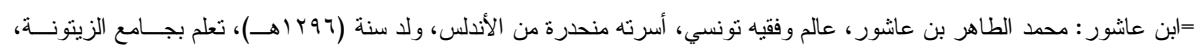

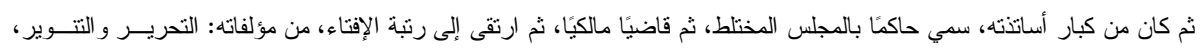
مقاصد الثريعة الإسلامية وغير ها. توفي سنة (Tو (T اهـ).

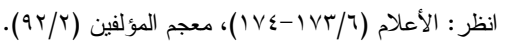

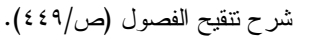

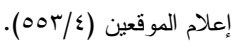

العدة (r/9/ ( ) ). 
قال إمام الحرمين: "الأمر بالثيء يتضمن اقتضاء ما يفتقر إليه وقوعه..."('). رابعاً: علاقة المقاصد بإبطال الحيل: أولاً: تعريف الحيل لغة واصطة المفاصدا: بإطال: تعريف الحيل لغة: اسم من الاحتيال، كالحيل، و الحول، و الحولة، وحســال يحيـلـ

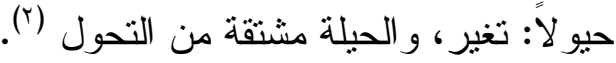
تعريف الحيل اصطلاحاً: عرفها الثناطبي: "بأنها تقديم عمل ظاهر الجواز لإبطال حكم شرعي وتحويله في الظاهر إلى حكم آخر "(").

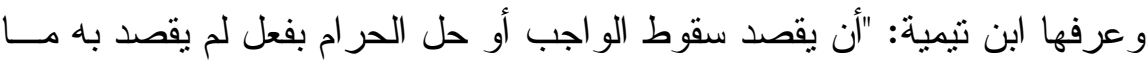

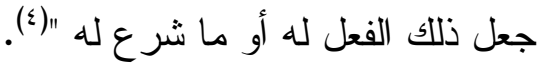
و عرفها ابن القيم: "المخادعة هي الاحتيال و المراوغة بإظهار أمر جائز ليتوصل

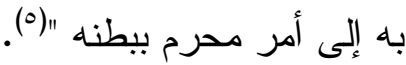

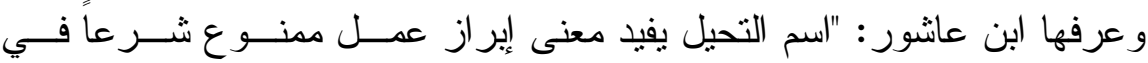

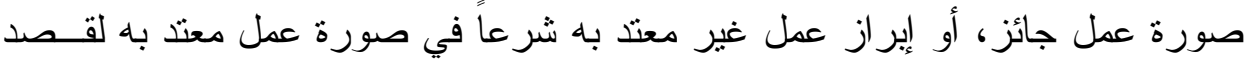

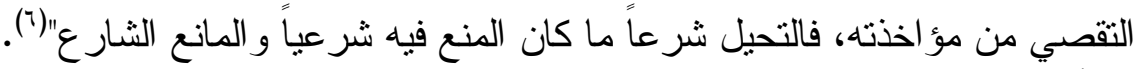

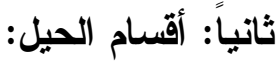

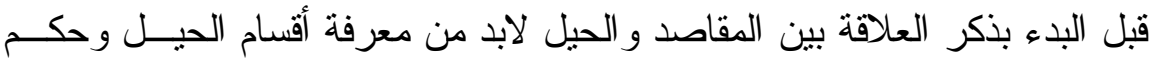
كل قسم منها، وقد سلك في تقسيمها مسلكان هما:

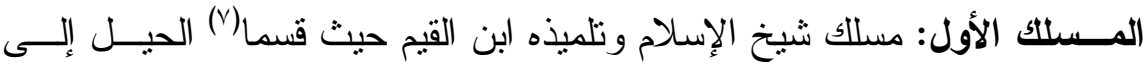
أقسام منها ما يأتي:

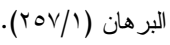

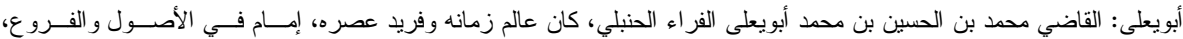

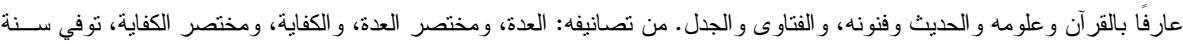

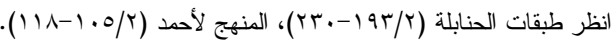

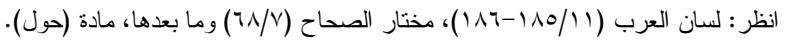

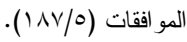

$$
\begin{aligned}
& \text { الفتاوى الكبرى (T/ (1) (1) (1). (1). }
\end{aligned}
$$

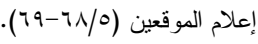

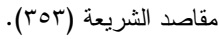

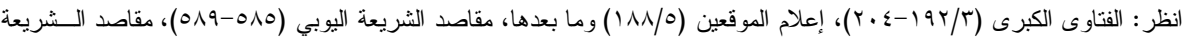


القسم الأول: الطرق الخفية التي يتوصل بها إلى ما هو محرم في نفسه، بحيــــ

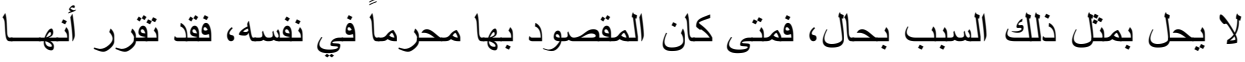

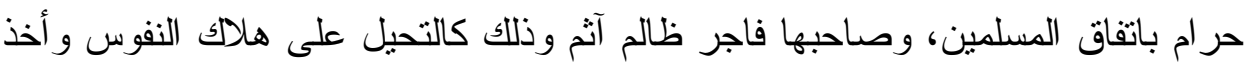

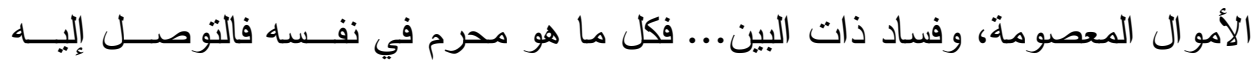

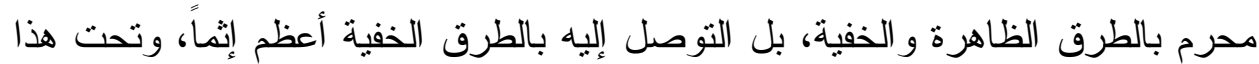

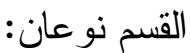

الأول: ما يظهر فيه أن مقصود صاحبه الثر و الظلم كحيل اللصوص فلا مـــخل لهذا في الفقه.

ما لا يظهر فيه ذلك بل يظهر صاحبه أن قصد الخير، و لا يمكن الاطلاع علـى مقصوده غالباً.

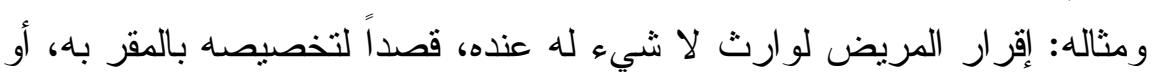

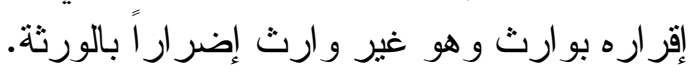

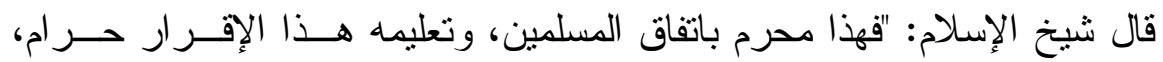

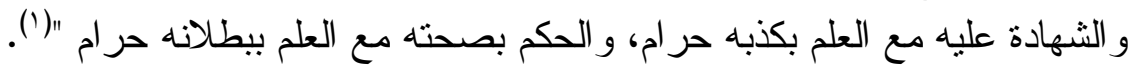

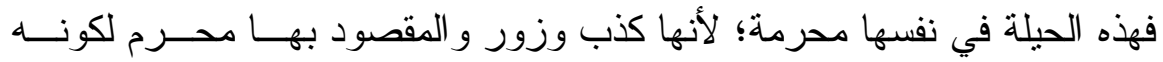
ظلماً و عدو اناً.

القسم الثاني: أن يقصد بالحيلة أخذ حق أو دفع باطل وهذا القسم ينقسم إلى ثلاثة

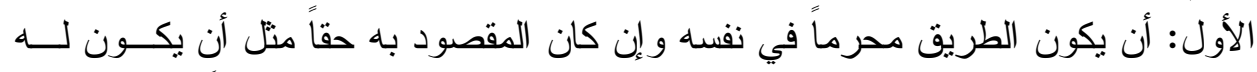

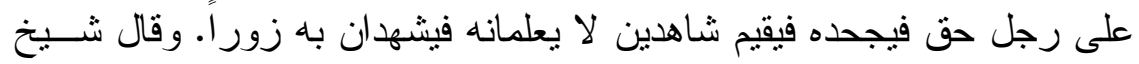

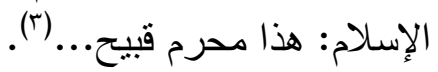

الثاني: أن يكون الطريق مشروعاً وما يفضي إليه مشروعاً وهذه هي الأســباب التـي

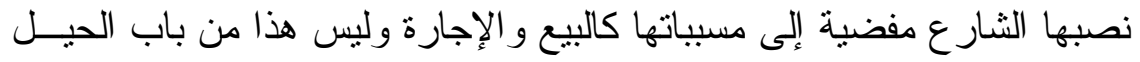

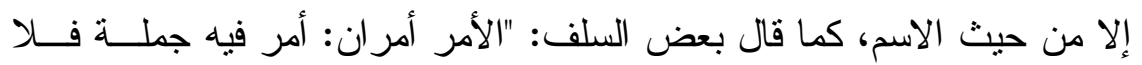

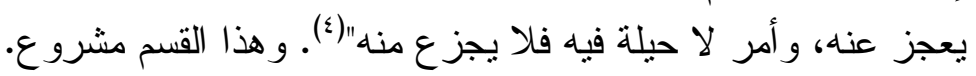




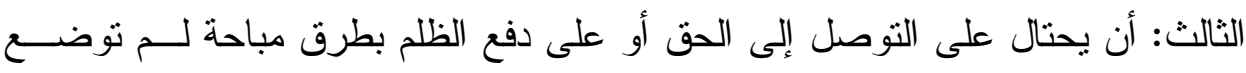

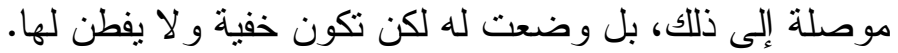

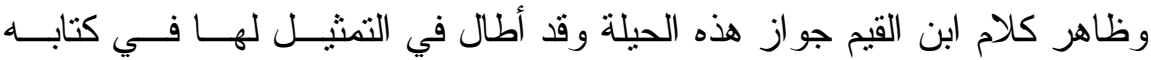
الإعلام (') و إغاثة اللهفان (؟) إنان

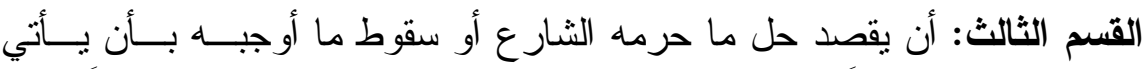

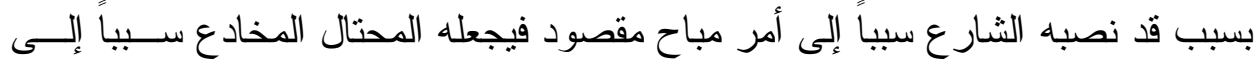
أمر محرم مقصود و هذا حر ام من وجهين. جهة غايته وقصده، وجهة سبود ولئه

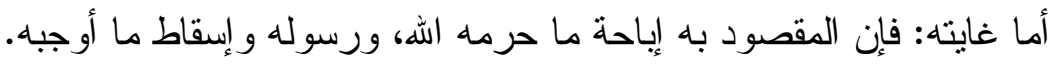

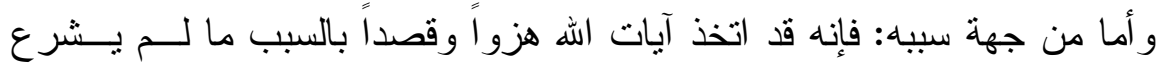

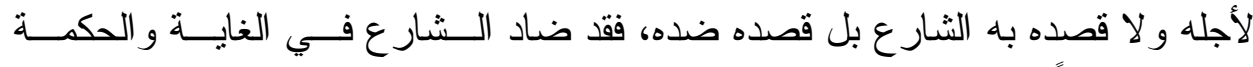
و السبب جميعاً.

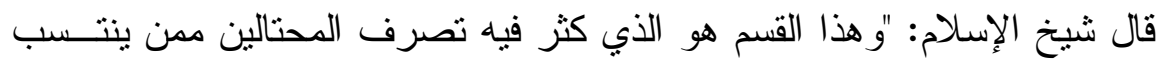

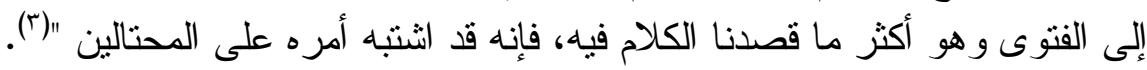

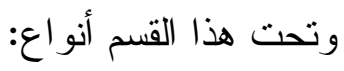

الأول: الاحتيال لحل ما هو حر ام في الحال، كالحيل الربوية، وحيل التحليل.

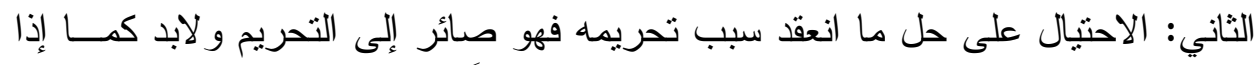

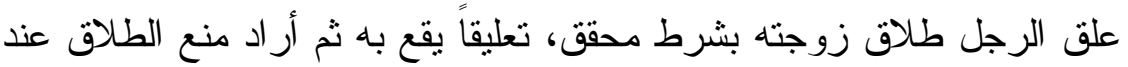

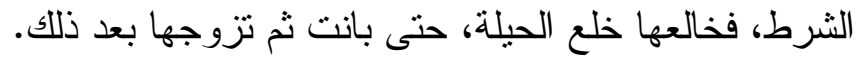
الثالث: الاحتيال على إسقاط ما هو واجب في الحال، كالاحتيال على إســقاط الإنفــاق

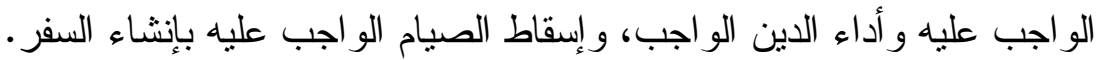

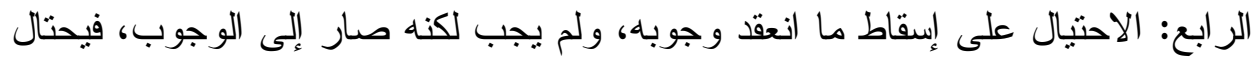

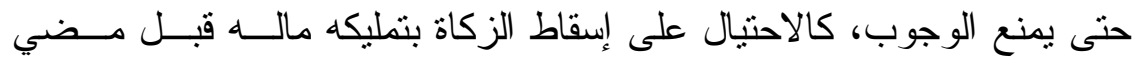

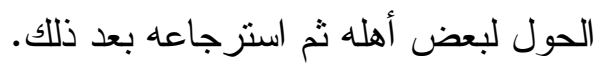

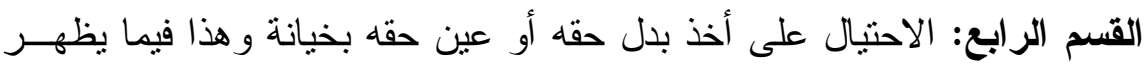

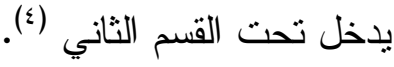

إغاثة اللهفان (r/ ( 
المسللك الثاني: مسلك الثاطبي قسم الحيل إلى ثلاثة أقسام ('):

القسم الأول: ما لا خلاف في بطلانه كحيل المنافقين و المر ائين. القسم الثاني: ما لا خلاف في جو ازه الاف كالنطق بكلمة الكفر إكر اهاً عليها. قال الثاطبي: "وكلا القسمين بالغ مبلغ القطع".

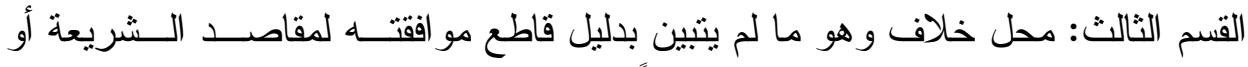

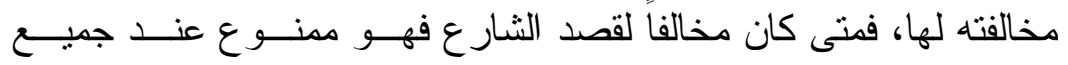

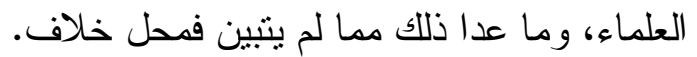

ثالثاً: علاقة المقاصد بإبطال الحيل(؟): بعد عرض مسالك الحيل تبين لنا:

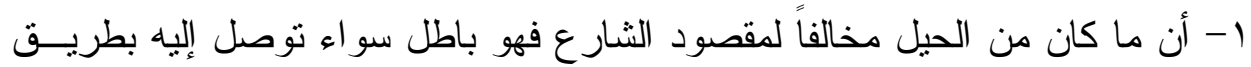

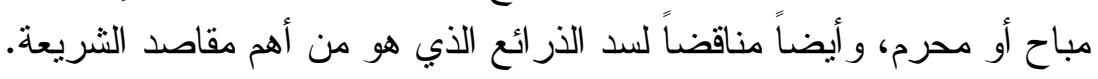

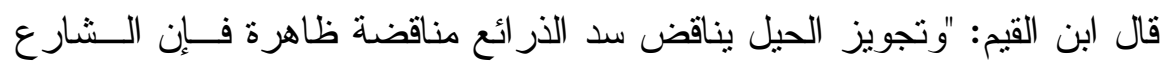

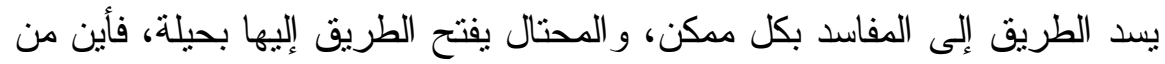
يمنع الجائز خشية الوقوع في المحرم إلى من يعمل الحيلة في التوصل إليه "(").

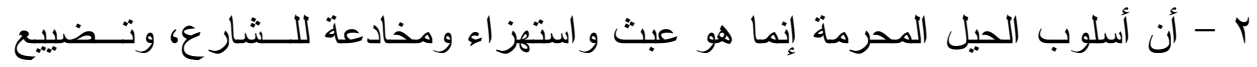
لمحاسن الثريعة.

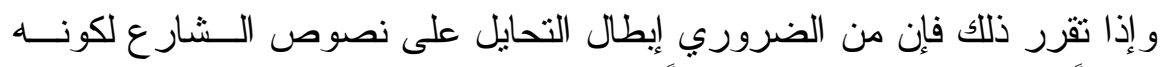

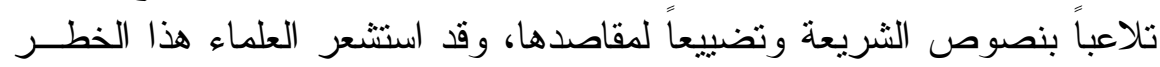

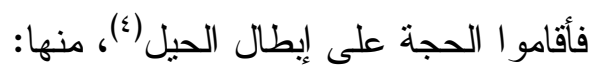
من الكتاب:

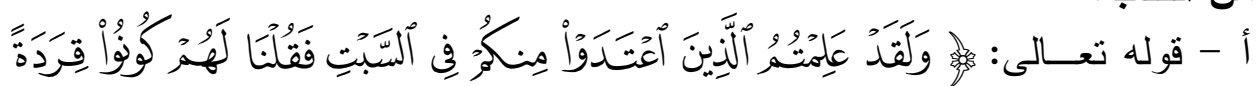

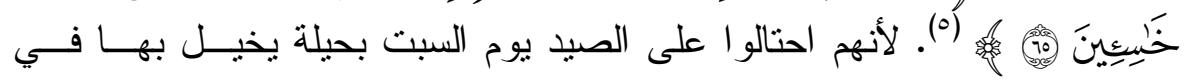
الظاهر أنهم يصيدوا في السبت. 


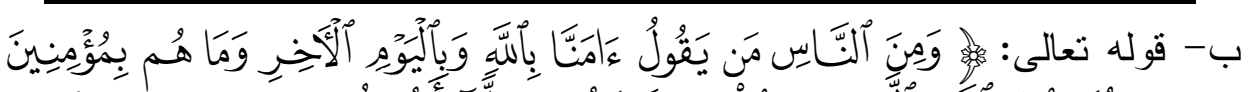

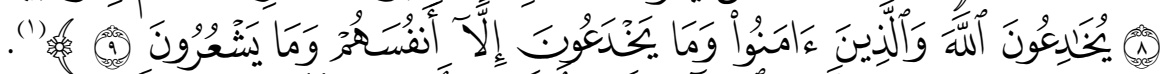

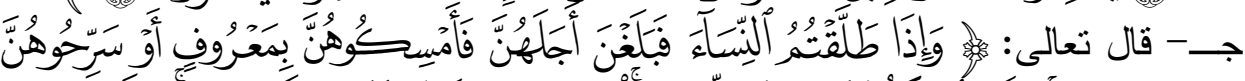

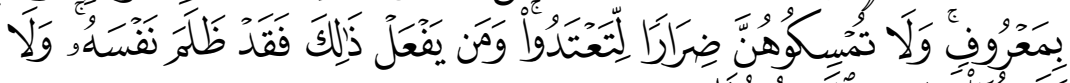

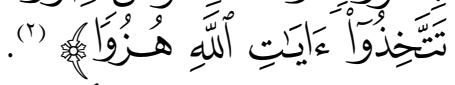

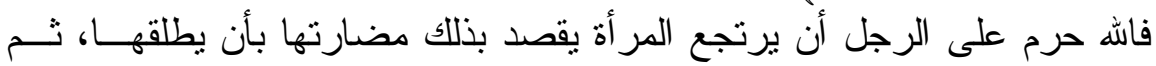

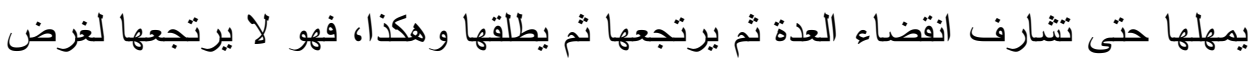

$$
\text { له فيها سوى الإضر ار بها (َّ). }
$$

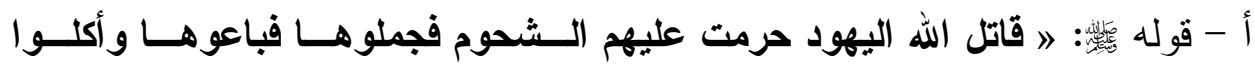

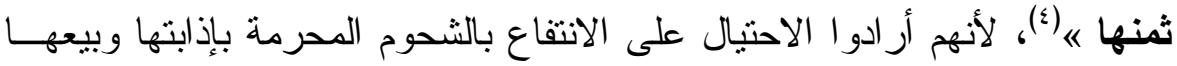

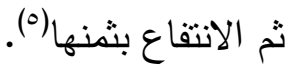

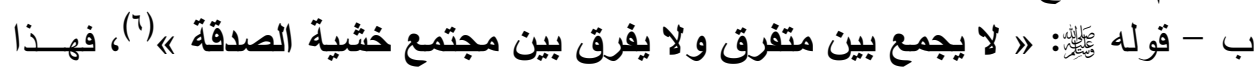

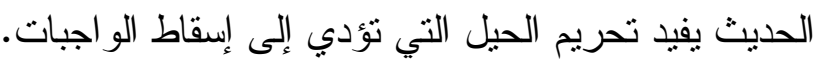
ج - قوله له في إبطال الحيل.

إلى غير ذلك من الأدلة الو اردة في إيطال الحيل (^).

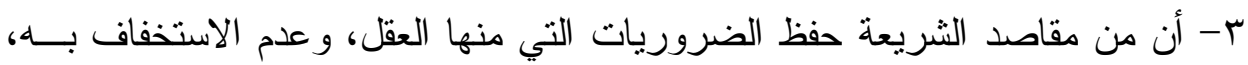
فهو مناط التكليف، من فقده فقد سقط عنه التكليف، وما الحيل و الخدع إلا استخفافاً

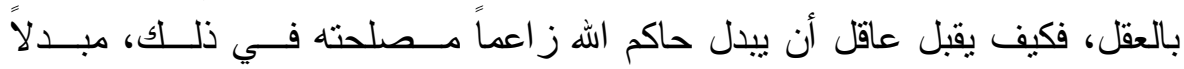
المصلحة بالمفسدة، هذا كله بسبب عدم إدر الك الحكمة و المصلحة و الغاية من أحكام

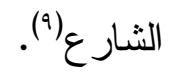

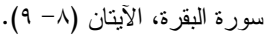

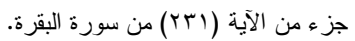

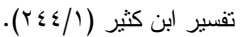

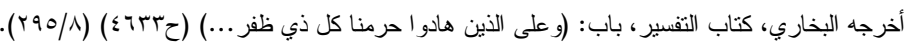

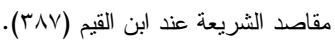

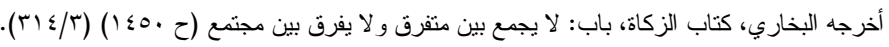

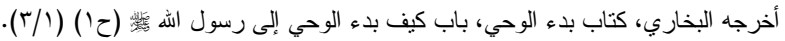

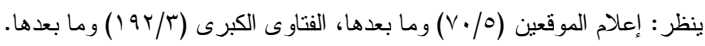

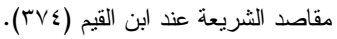


المسألة الرابعة: علاقة المقاصد بقول الصحابي: أولاً: تعريف الصحابي لغة واصطة الصغلاحاً:

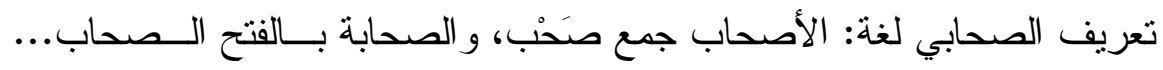

وكل شيء لازم شيء فقد استصحبه، وصحبه: عاشره.

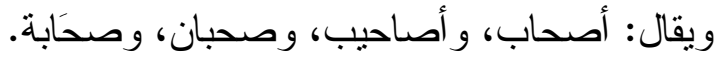

و استصحبه: دعاه إلى الصحبة و لازمده (1).

فالصحبة في اللغة: تتضمن معنى الملازمة، و والمعاشرة في المر افقة.

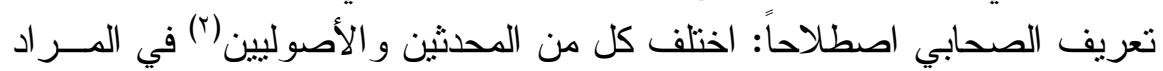
بالصحابي على أقو ال كثيرة لعل الر اجح منها سو الله أعلم-: تعريفه:

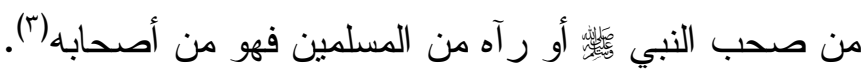

وجه الترجيح:

أن الصحابي اسم مشتق من الصحبة، و الصحبة تعم القليل و الكثير ، ومنه يقـال:

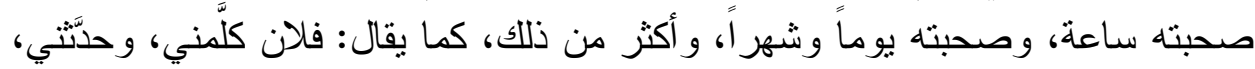

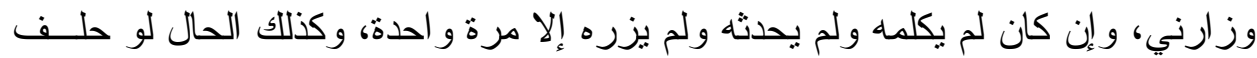

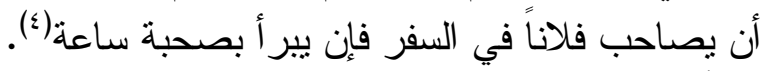
ثانياً: حجية قول الصحابي: المسألة محل خلاف بين الأصوليين وقبل ذكر الخلاف فيها نحرر محل النــزاع

في المسألة. تحرير محل النزاع في المسألة: 1- لا خلاف بين العلماء أن قول الصحابي لا يكون حجة على على صـــابي آخـر مــن المجتهدين (0).

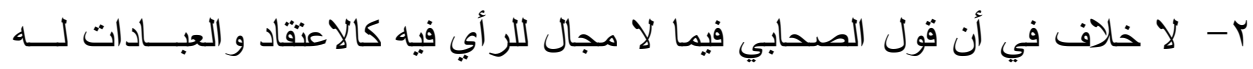

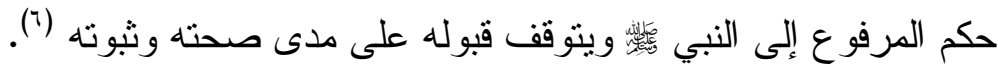

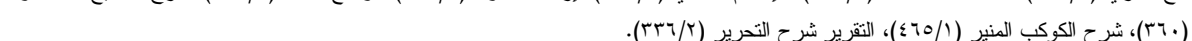

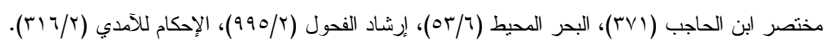




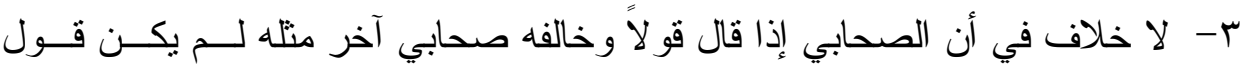

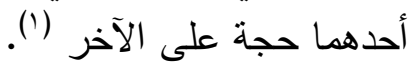

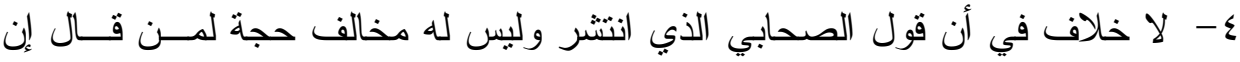

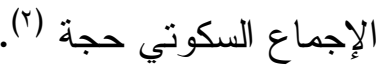

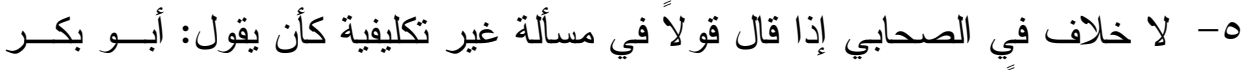

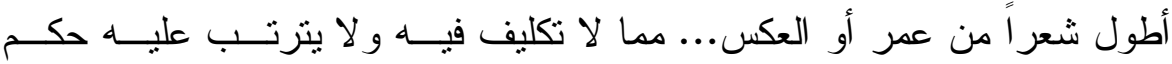

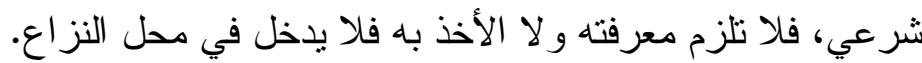

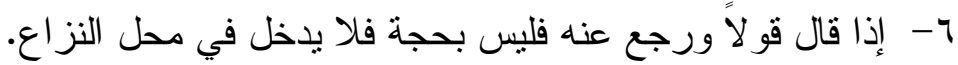

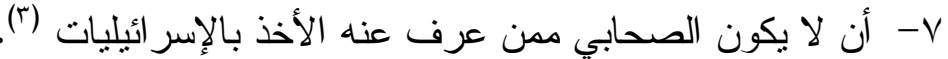

اختلف العلماء في الاحتجاج بقول الصحابي إذا لم ينتشر ولم يظهر له مخــالف الصابل

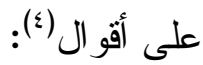

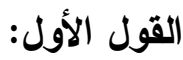

أن مذهب الصحابي حجة مطلقاً سواء و افق القياس أو خالفـه، و لا فــرق بـين

الخلفاء الر اثندين وغير هم من الصحابة، قال به الأئمة الأربعة.

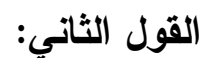

أن مذهب الصحابي ليس بحجة مطلقاً سو اءو وافق القيــاس أو خالفـه، اختــاره

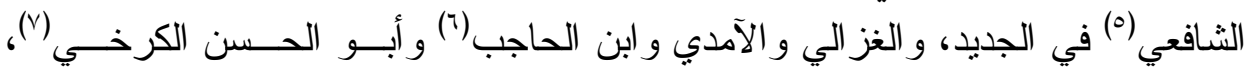

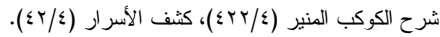

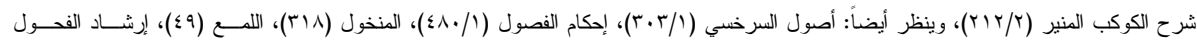

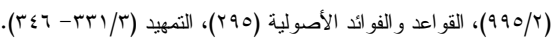

المذكرة للشنقيطي (170) (170).

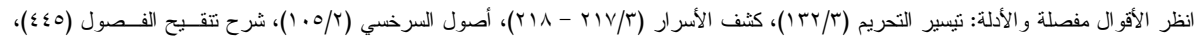

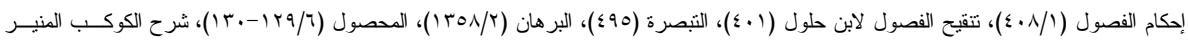

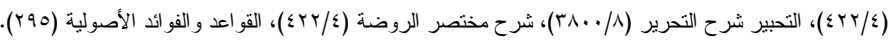

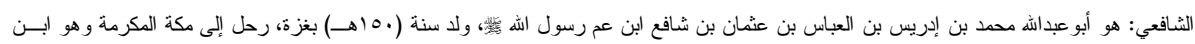

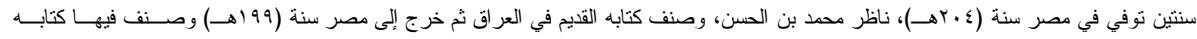

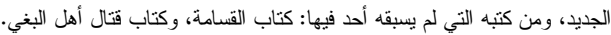

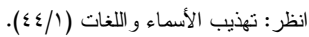

ابن الحاجب: جمال الدين عثمان بن عمر بن أبوبكر، المشهور بابن فقيه مالكي من كبار العلماء بالعربية وأصول الفقه، ولد في إسنا من صعيد مصر ســنة

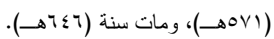

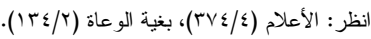

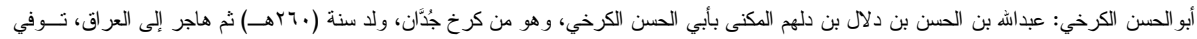

سنة (• § اهـ)، من أثنهر مصنفاته: رسالة الكرخي ذكر فيها الأصول التي دار عليها مدار كتاب أصحاب أبي حنيفة.

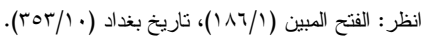


أن الحجة قول الخلفاء الر اشدين الأربعة دون غيرهم.

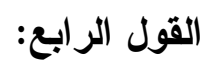

أن الحجة في قول أبو بكر وعمر دون غيرهما.

القول الخامس: - (ان

أن قول الصحابي حجة إذا خالف القياس و إلا فلا اختاره البزدوي(؟).

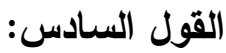

أن قول الصحابي حجة إذا انضم إليه قياس ثقريب، صــرح بهــذا الـسبكي(")،

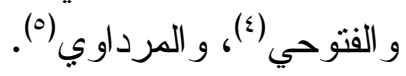

القول السابع:

أن الحجة في قول الخلفاء الثثلاثة أبو بكر وعمر وعثمان رضي اله عـنهم دون

غير هم نسبه السبكي للشافعي. القول الثامن:

أن الحجة في قول الصحابي إذا و افق القياس و إلا فلا. الراجح -و الله أعلم - القول الأول أن قول الصحابي حجة مطلقاً وذلك:

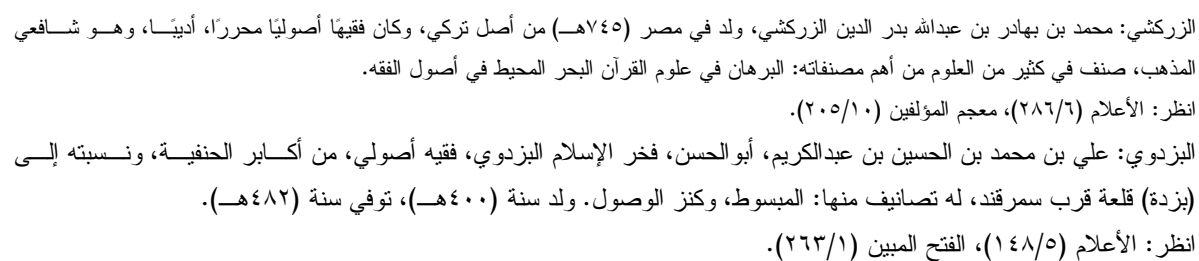

السبكي: بدر الدين محمد القاضي بهاء الدين أبو البقاء السبكي الثافعي،قاضي قضاة مصر ، نولى منصبه عوضيًا عن قاض القضاة برهان

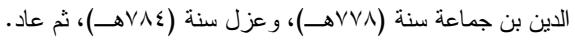

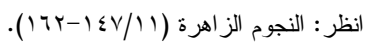

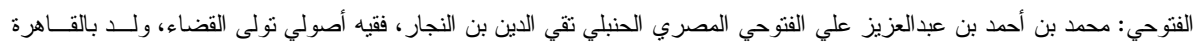

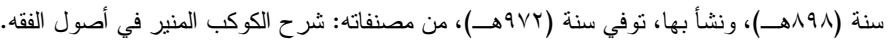

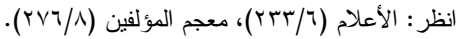

المرداوي: هو أبو الحسن علاء الدين، علي بن سليمان بن أحمد بن محمد المرداوي، السعدي الصالحي الحنبلي، شيخ المــذهب و إمامــهـ

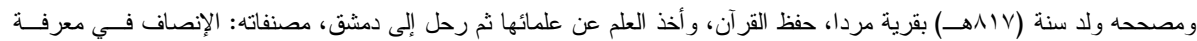

$$
\begin{aligned}
& \text { الر اجح من الخلاف، التحبير شرح التحرير ، نوفي سنة (1/10هـ). }
\end{aligned}
$$

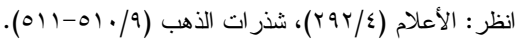


أ- أن نصوص القر آن و السنة تدل على حجية قول الصحابي و اعتباره و الثتــاء عليــــ

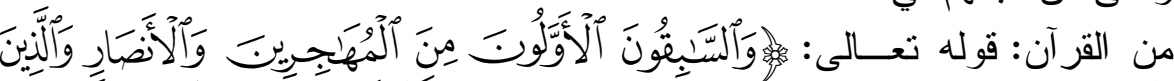

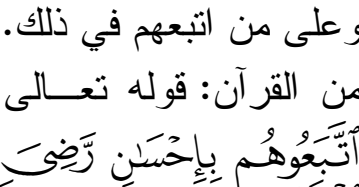

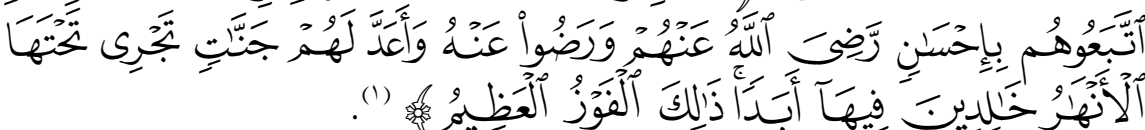

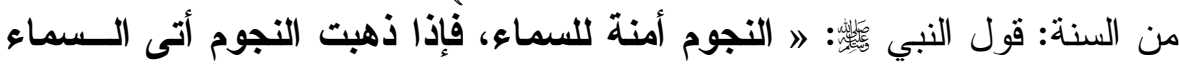

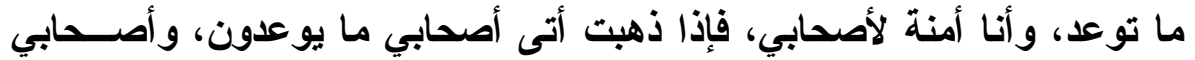

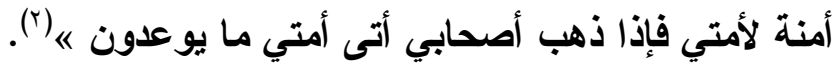

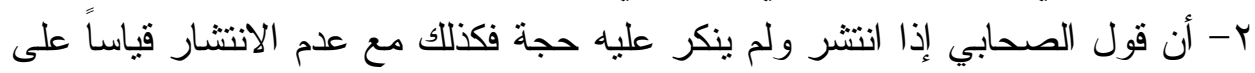

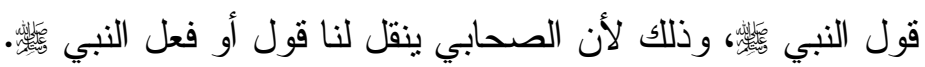
ثالثاً: علاقة المقاصد بقول الصحابي:

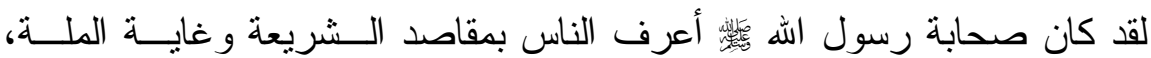

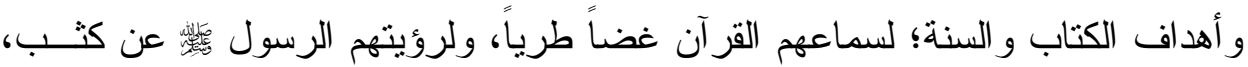

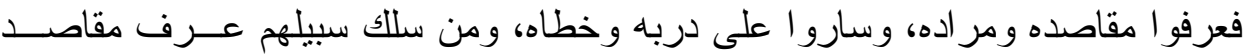

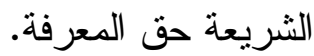

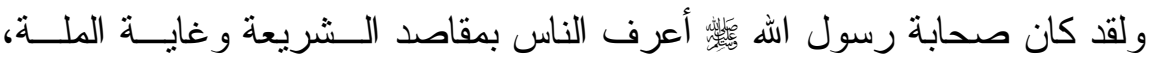

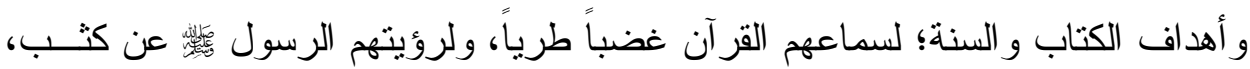

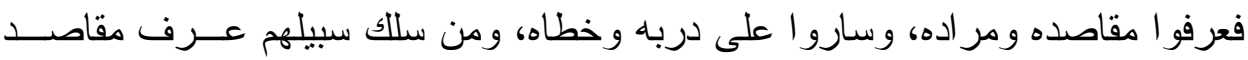

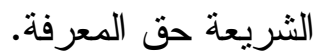

ولقد بذل الصحابة قصار جهدهم في استتباط الأحكام بعد أن وقفو العى أســرار

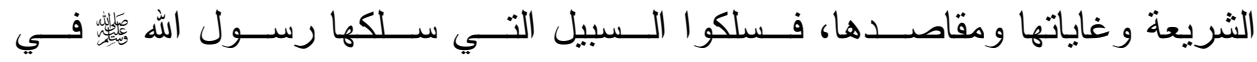

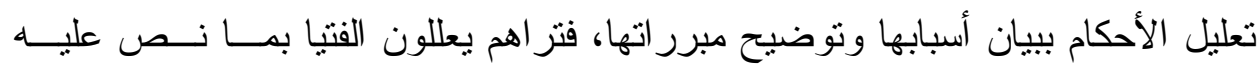

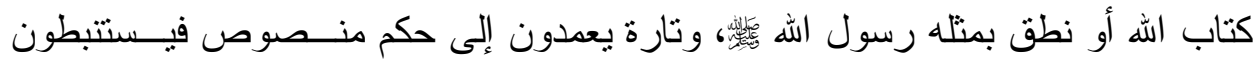
علته (r).

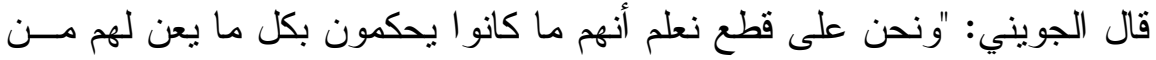

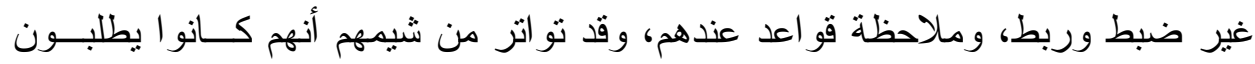

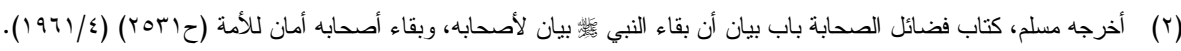




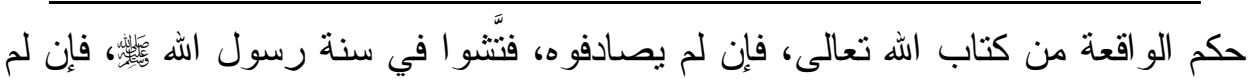

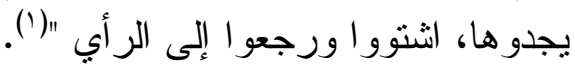

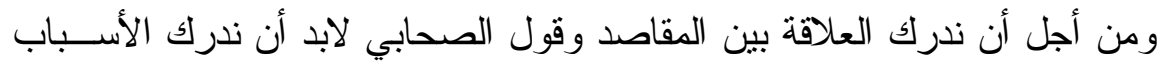
التي بو أهم الله بها هذه المكانة وهي:

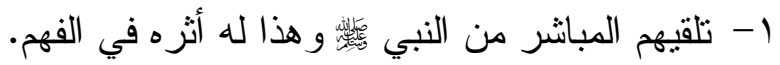

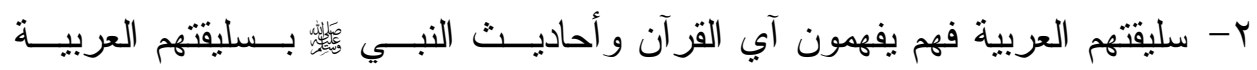
ويعرفون وجوه دلالتها العربية.

ب- إخلاصهم لله وتثق اهم لله فبيركة إخلاصهم نالو ا العلوم الكثيرة النافعة، فـــي أوقــات قليلة) (T)

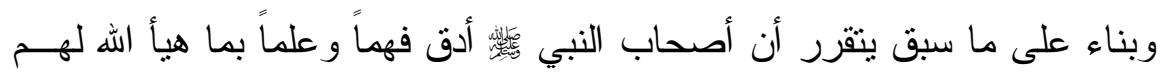

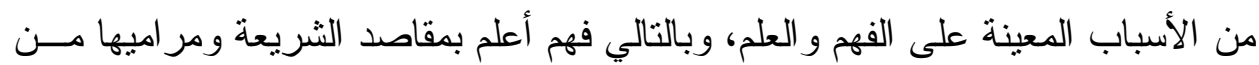
غير هم.

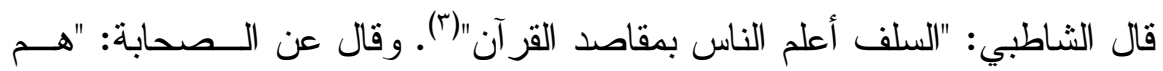
القدوة في فهم الشريعة و الجري على مقاصدها"(أ). وبذلك تتضح العلاقة بين الاحتجاج بقول الصحابي و المقاصدي مقاصدي

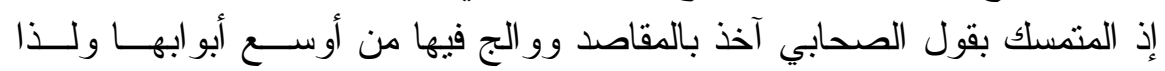

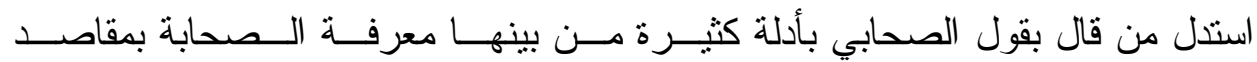

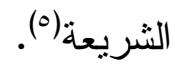

من الأمتلة على مر اعاة الصحابة لمقاصد الثريعة(؟): ا 1

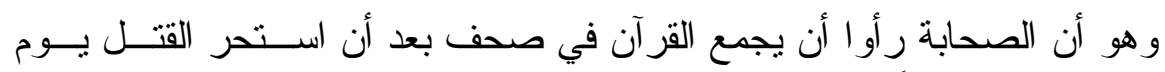

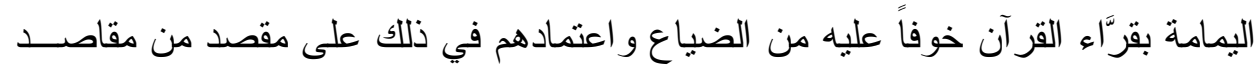
الشريعة، وهو جلب المصلحة المتعلقة بالدين ودر ع المفسدة عنده.

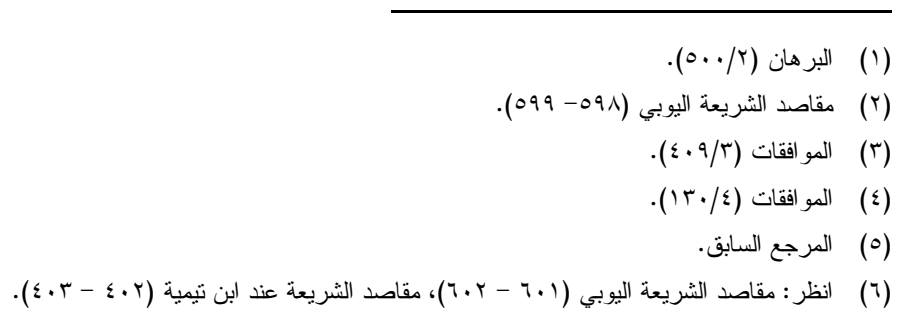




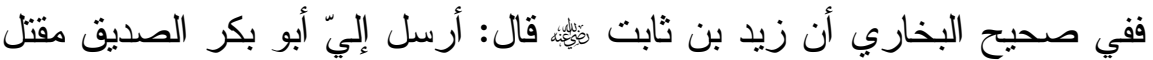

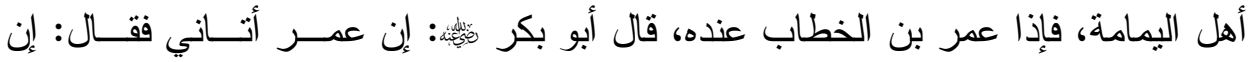

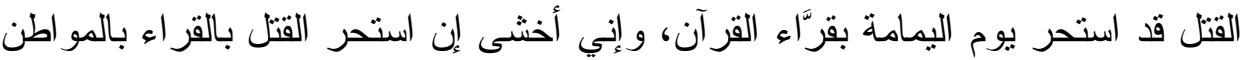

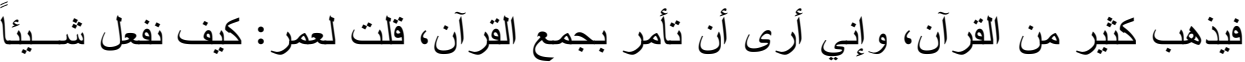

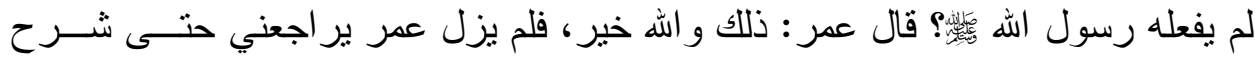

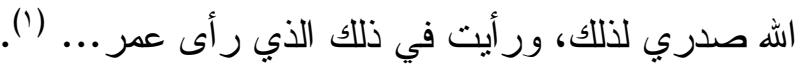

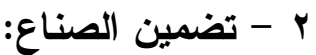
وذللك حفظاً لأمو ال الناس من الضياع، قال الــشاطبي: "إن الخلفــاء الر اثثــدين

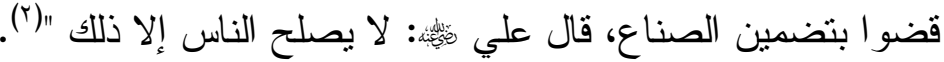

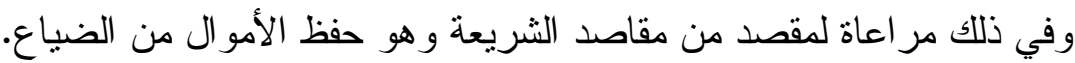
r - إسقاط سهم المؤلفة قلوبهر:

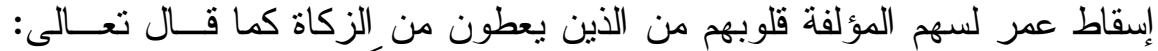
(")

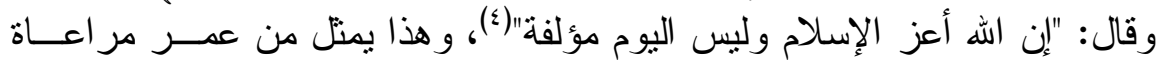

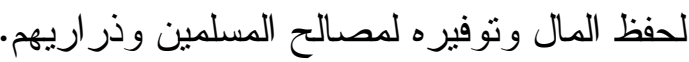

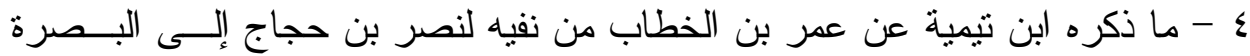

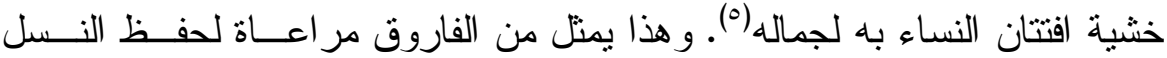

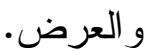
ومما سبق فإن حياة الصحابة تعتبر نموذجاً حياً و عمليــاً مــن خــلال إعمـالهم لمقاصد الثريعة، و الاعتدال و التوسط في تطبيق الأحكام الثر عية. المسألة الخامسة: علاقة المقاصد بالعرف: أولاً: تعريف العرف لغة و اصطلاحاً:

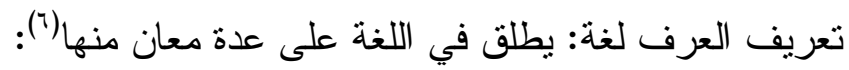

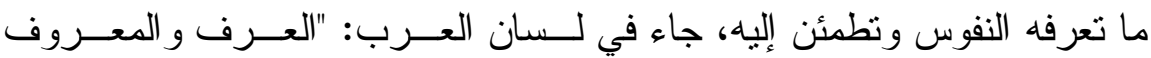
و العارفة واحد ضد النكر وهو كل ما تعرفه النفوس من الخير وتطمئن إليه ". 
و أيضاً اسم من الاعتر اف الذي هو بمعنى الإقرار، و العرف: شعر عنق الفرس.

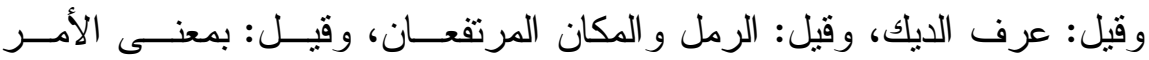
المتتابع عليه، وقيل: اسم لما تبذله وتعطيه.

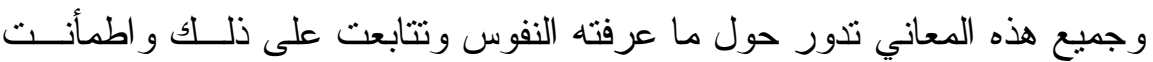

\section{إليه. \\ تعريف العرف اصطلاحاً:}

عرفه الجرجاني: "ما استقرت النفوس عليه بـشهـادة العقــول، وتلقتـــه الطبــائع

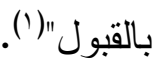

و عرفه القر افي: "غلبة معنى من المعاني على الناس، وقد تكون هذه الغلبـــة فــي

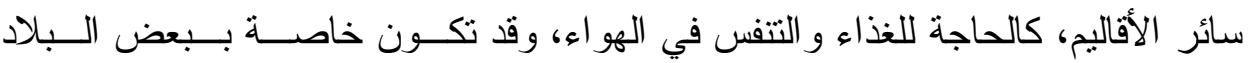

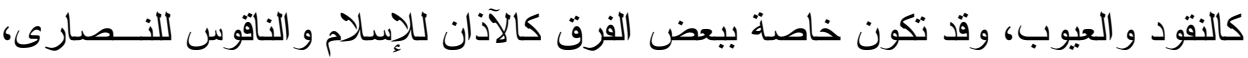

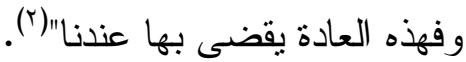
ولعل تعريف الجرجاني أولى لإيجازه وكونه جامعاً مانعاً.

ثانياً: حجية العرف: تعزئ

العرف من الأدلة المعتبرة في الجملة عند جميع المذاهب(َ)، و إن حصل خــلاف

في الثفاصيل.

فالمذاهب الأربعة تتخذه منهجاً في تطبيق الأحكام الثر عية بين موسع ومضيق.

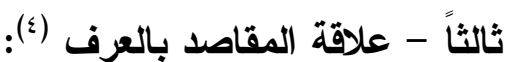

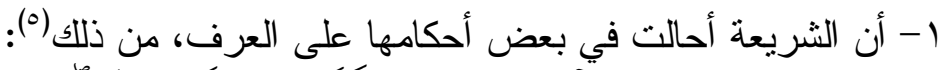

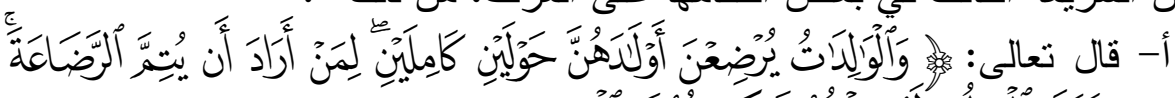

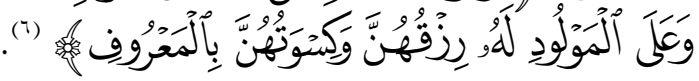

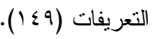

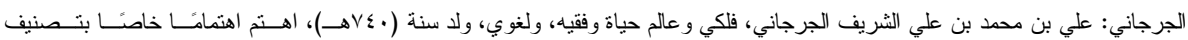

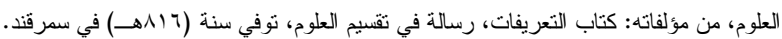

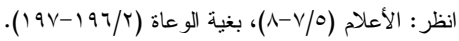

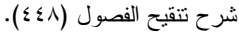

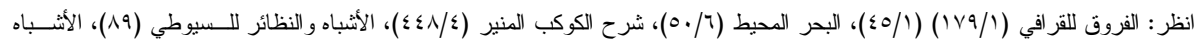

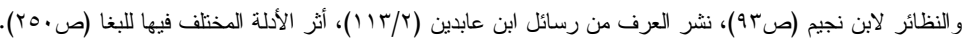

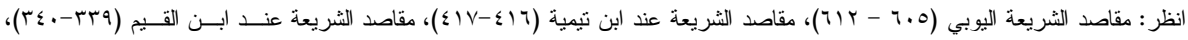

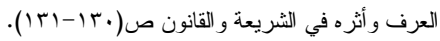

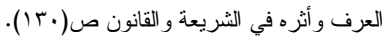

جزء من الآية (TrT) من سورة البقرة. 
قال ابن جرير : "ويعني بقوله:

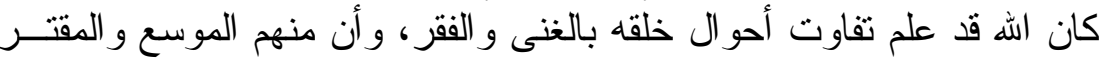

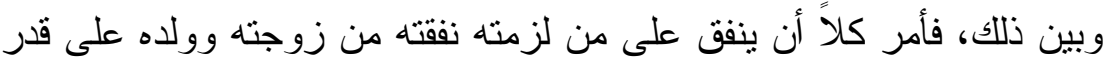

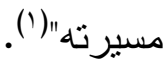
و لا تعرف المثلية إلا بمعرفة العرف السائد في المجتمع، وهذا الــذي أحالــــ عليه الآية، و إذا تأملنا ما قاله ابن جرير من قوله: "بما يجب لمنتلها على ولى منله"

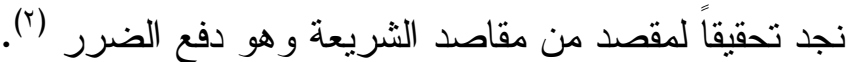

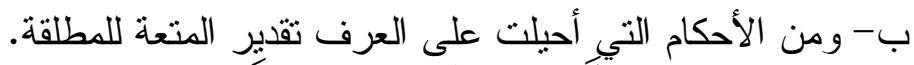

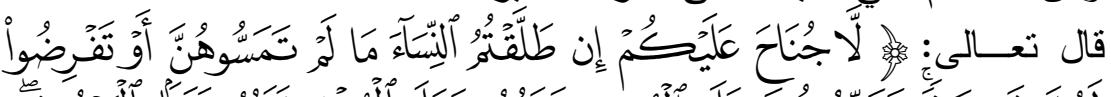

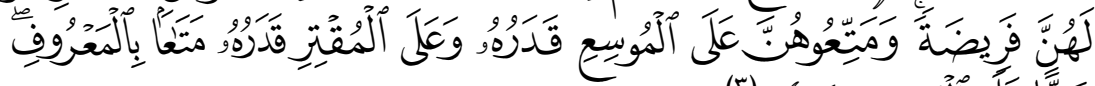

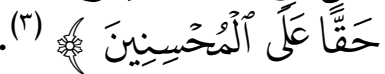

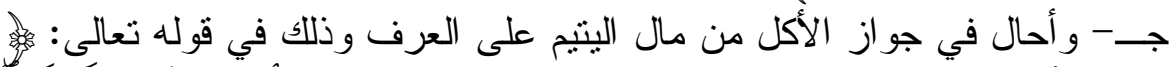

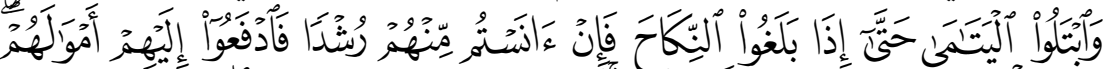

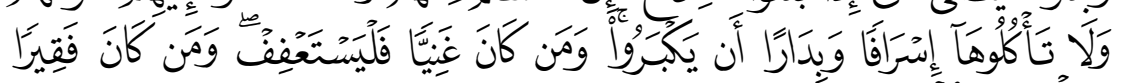

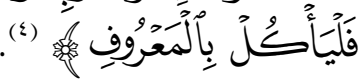

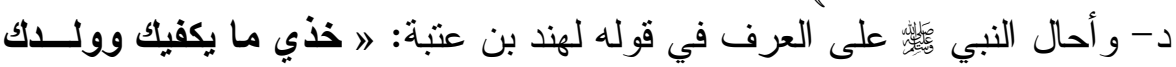

$$
\text { بالمعروف « (ن) }
$$

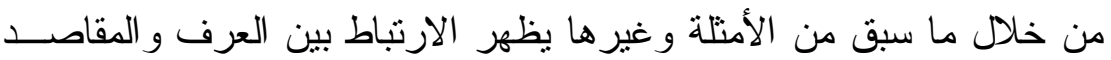

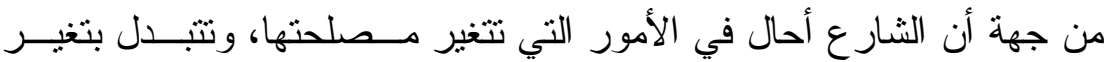

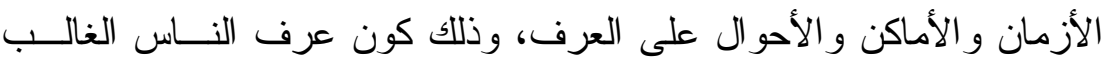

$$
\text { يحقق المصلحة المرجوة من هذه الأحكام. }
$$

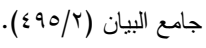

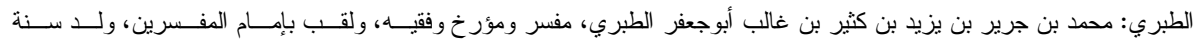

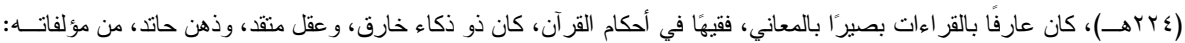

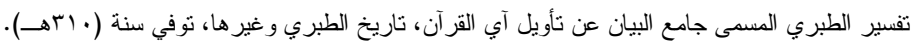

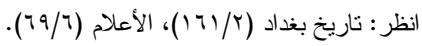

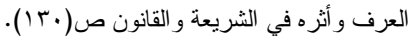

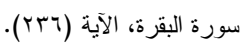

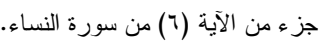

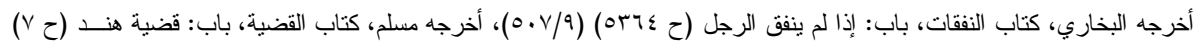


وفيه تحقيق لمقصود الثار ع حيث تكون هذه الثريعة صــالحة لكـل زمــان

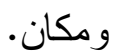

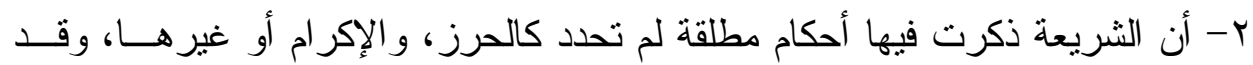

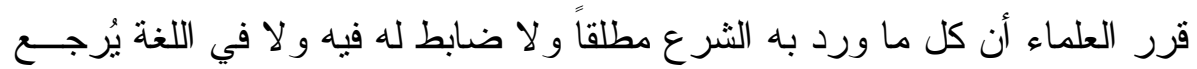

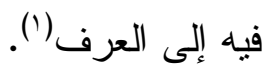
وما ذلك إلا لكونه يختلف باختلاف الأعراف، و الأزمان، و الأماكن، فكـان طريـق تحصيله العرف.

r- أن عدم الأخذ بالعرف يدفع الناس إلى أن يناقضو ا مقــصود الــشارع باســــال

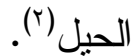

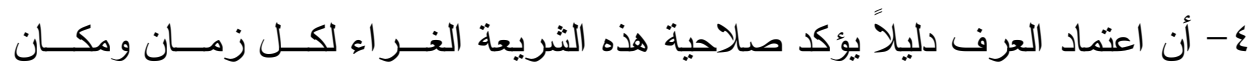

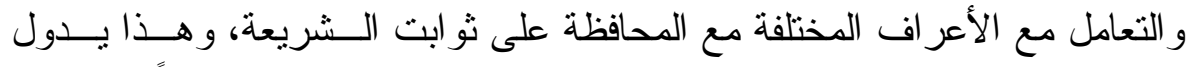

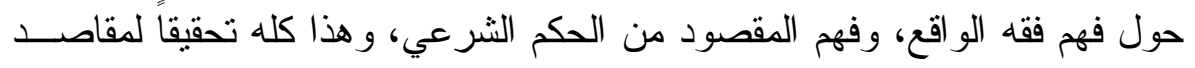

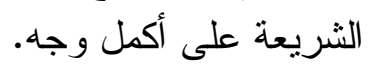

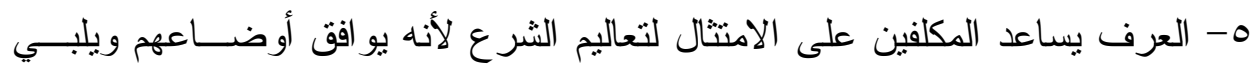

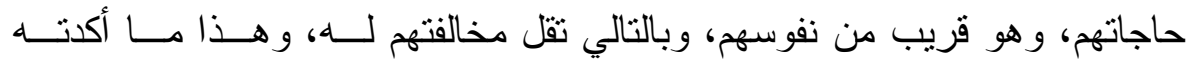

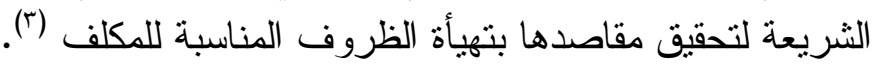
צ- أن العلماء قرروا أن الأحكام الاجتهادية العبنية على العرف تلتغير بتغيـــر الأزمــان

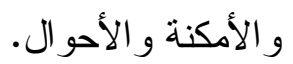

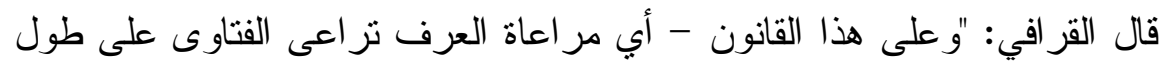

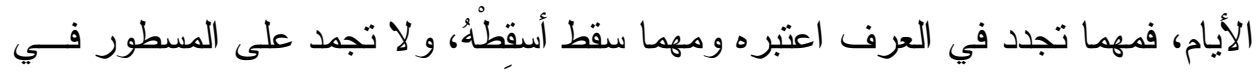

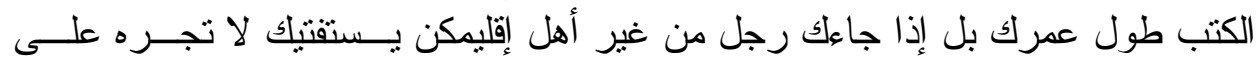

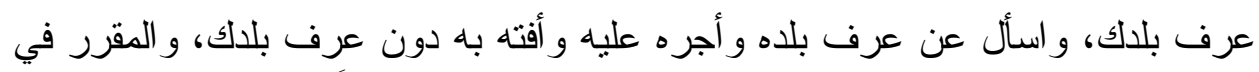

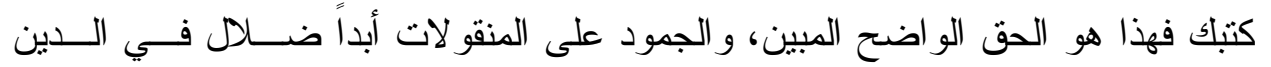

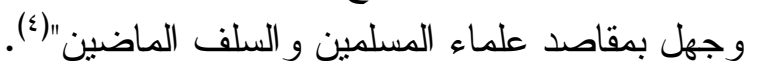

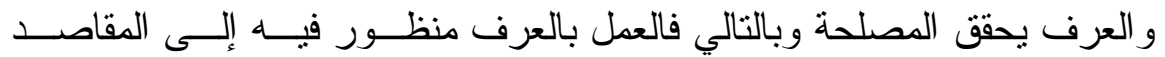

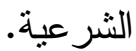

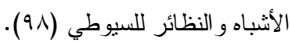

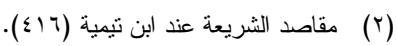

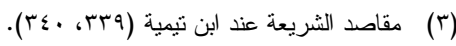

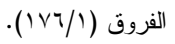


المسألة السادسة: علاقة المقاصد بشرع من قبلنا:

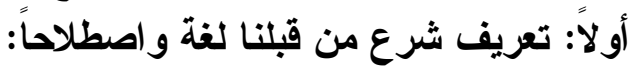

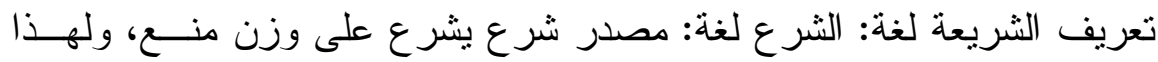
الفعل معان كثيرة منها: أ - تتاول الماء بالفم من غبر إناء، فيقال: شرع عال الوارد يشرع إذا تتاول الماء بفيه.

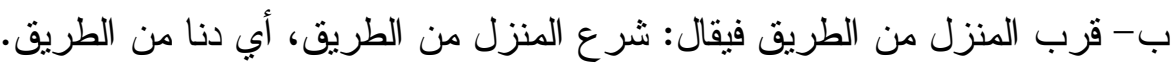

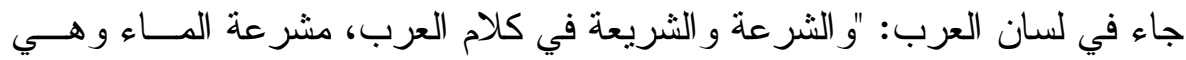

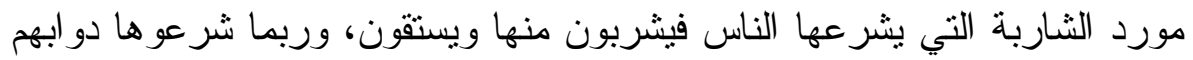
حتى نترب منها. و العرب لا تسميها شريعة حتى يكون الماء عدا الانقطاع له، ويكون ظاهر اً، معينــاً

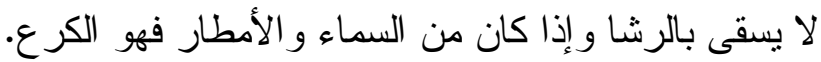

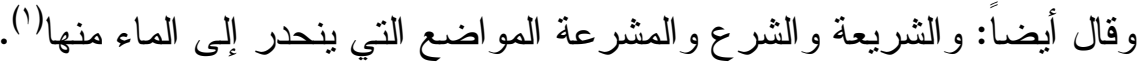

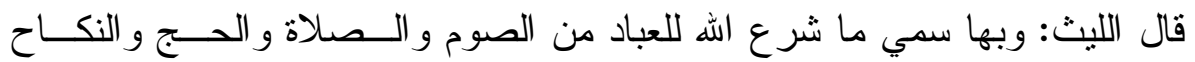
و غيرِ (r)

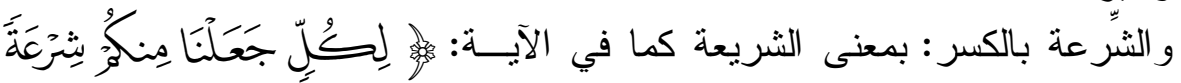

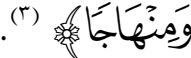

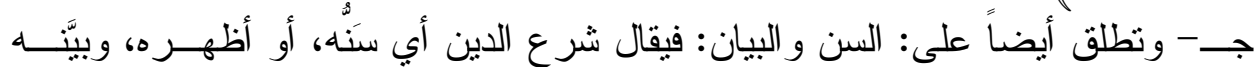

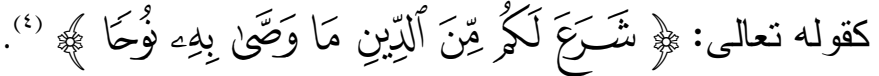

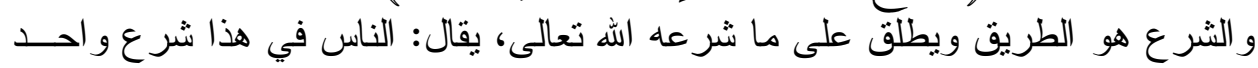
أي سو اء (0). تعريف شرع من قبلنا اصطلاحاً:

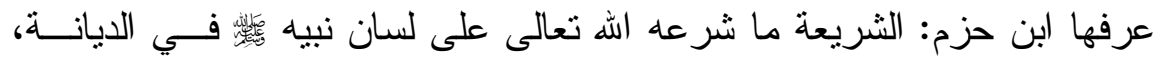

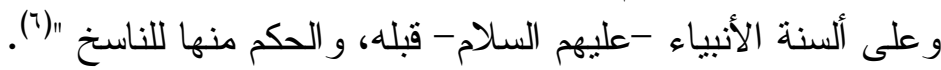

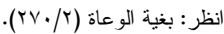
جزء من الآية (^§) من سورة المائدة. جزءمن الآية (rآ) من سورة الشورى.

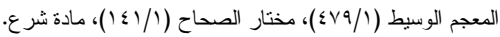

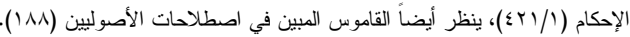




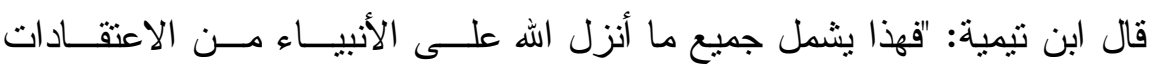

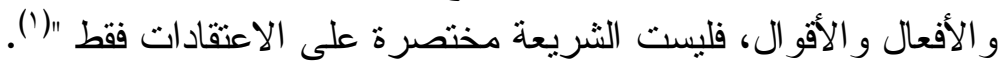

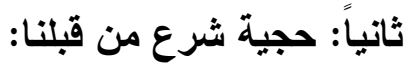

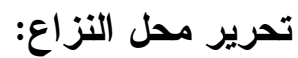

أ - ما لا تختلف فيه الشرائع، كالتوحيد و العقيدة، مما يجب لله تعالى، أو ينزه عنه لبس

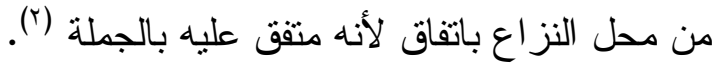

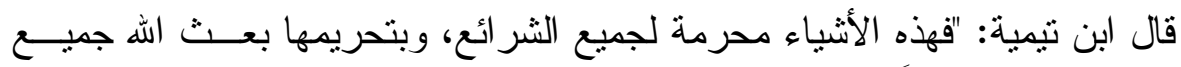

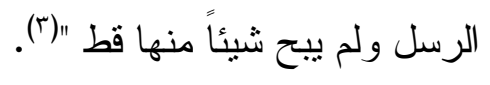

ب- ما تختلف فيه الثر ائع وهو خمسة أقنسام:

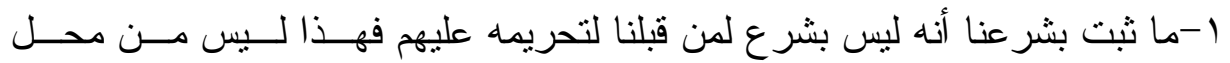

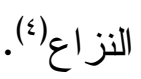

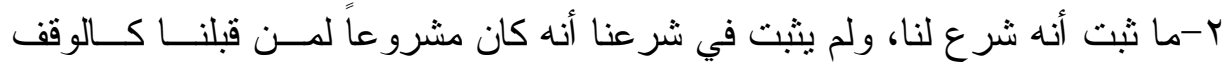

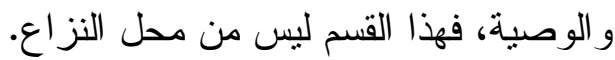

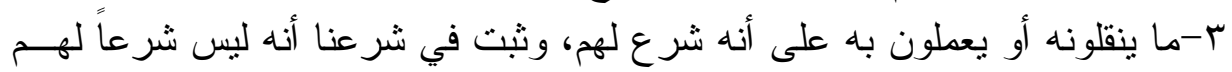

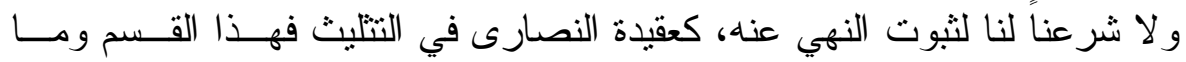

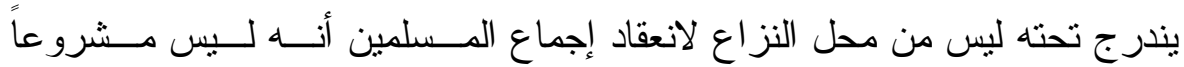
لهم (م) ع -ما نقل إلينا من شر ائع من قبلنا في كتب أصحاب تلك الــشرائع، أو علــى ألــسنة

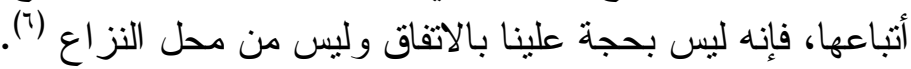

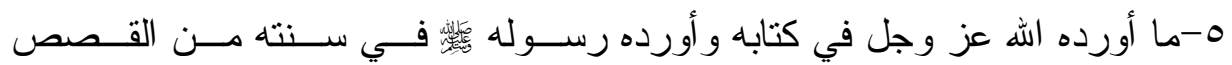

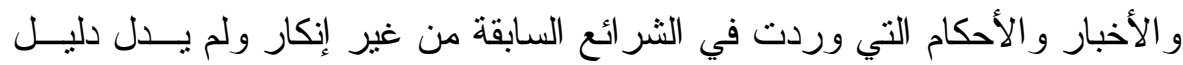

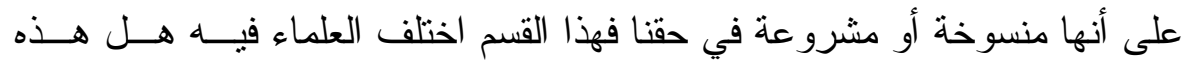
الأحكام شرع لنا وملزمون بها أو أنها نقلت على على سبيل الإخبار .

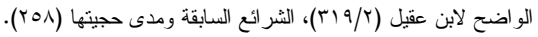

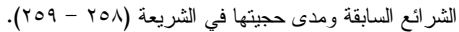




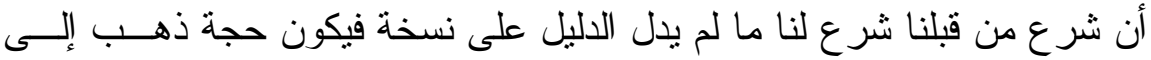

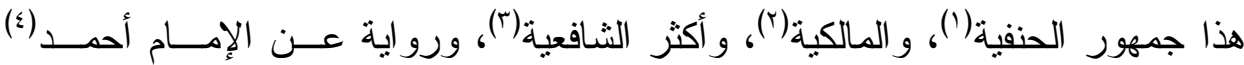
اختار ها أبو الفضل التيمي(0) من أصحابه(؟). القول الثاني: - الثنا

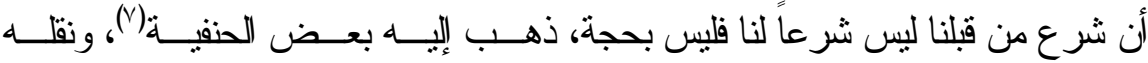

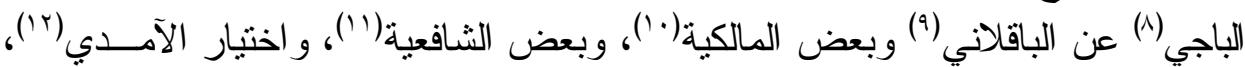

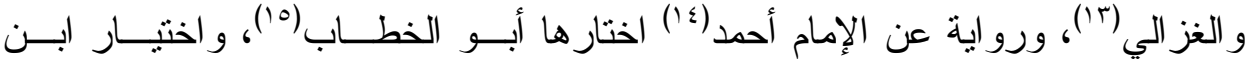
حزم)

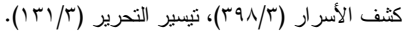

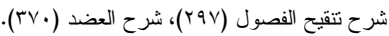

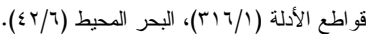

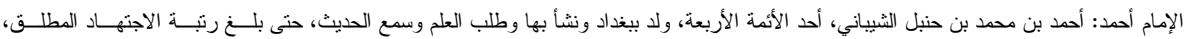

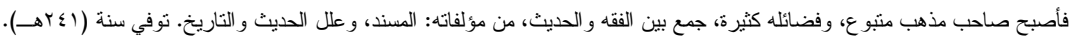

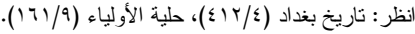

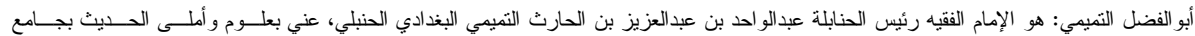

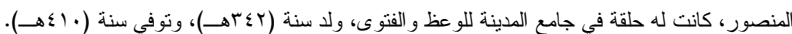

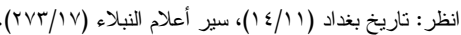

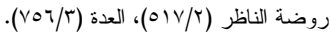

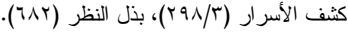

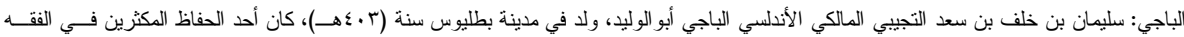

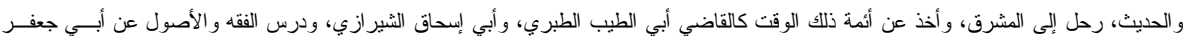

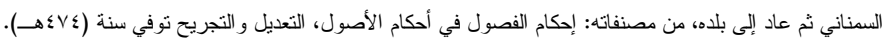

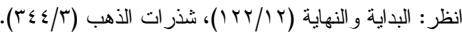

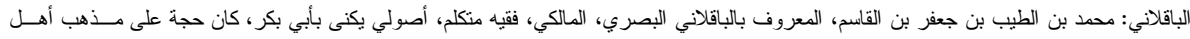

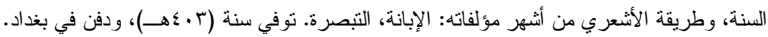

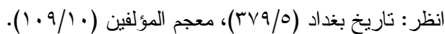

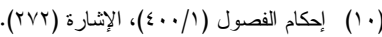

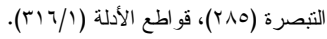

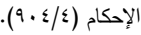

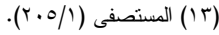

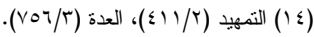

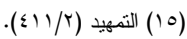

أبو الخطاب: هو محفوظ بن أحمد بن الحسن الكلوذاني، أبو الخطاب البغدادي الحنبلي، أحد أئمة الدذهب الحنبلي فقيه أصولي، أديب ثقة، له تصانيف كثيــرة

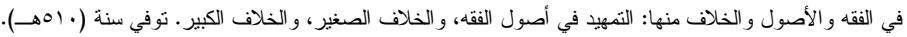

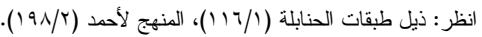

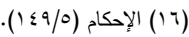


الوقف في المسألة حكاه الزركثي عن ابن القشيري(') و ابن برهان(؟).

يظهر لي أن الر اجح -و الله أعلم- القول الأول وذلك:

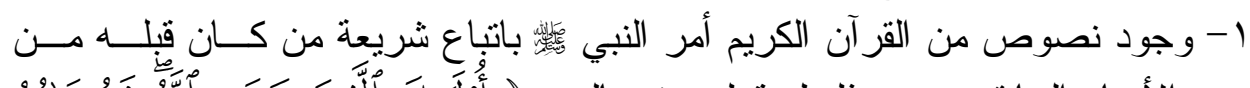

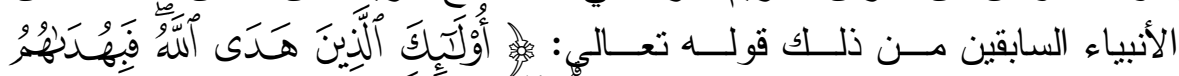

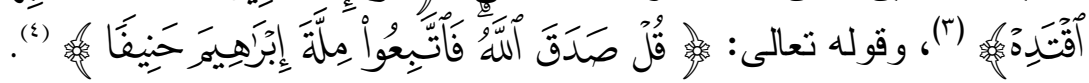

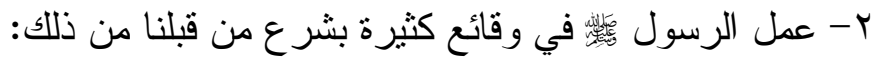

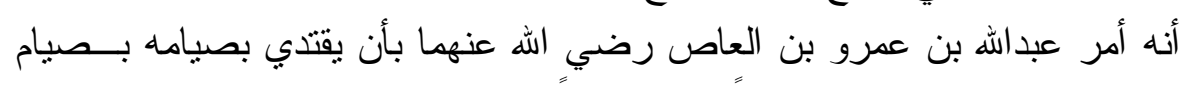

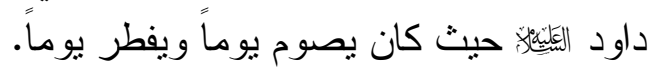

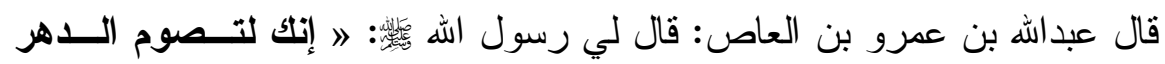

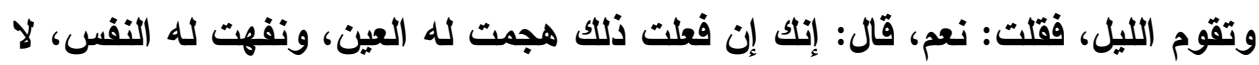

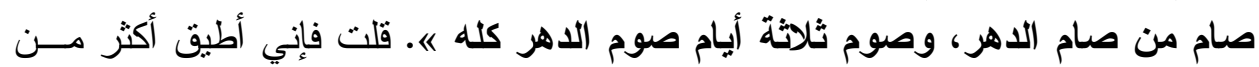

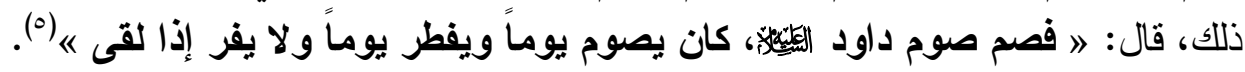

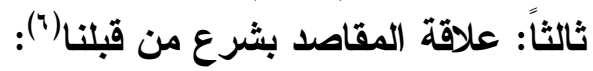

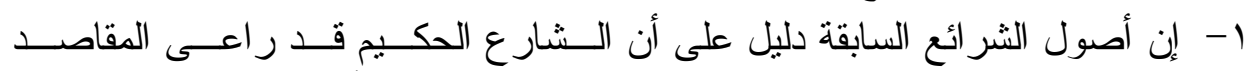

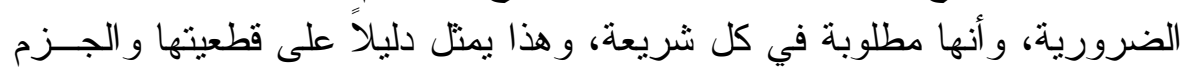
بثبوتها.

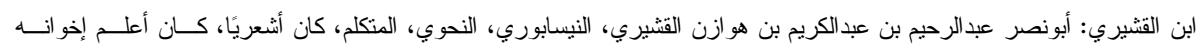

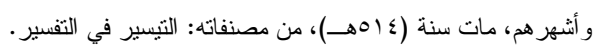

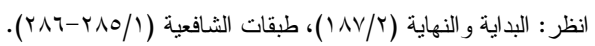

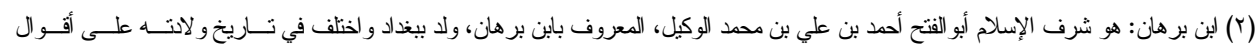

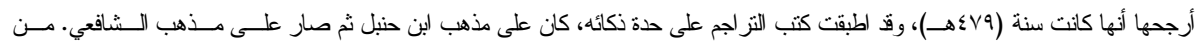

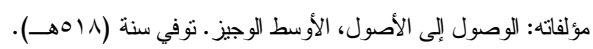

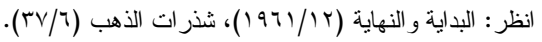

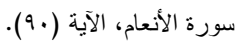

سورة آل عمر ان، الآية (90).

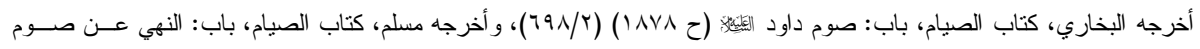

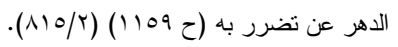

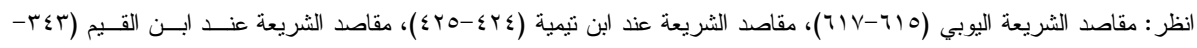


r- أن أعظم المقاصد و أشرفها عبادة الله سبحانه وتعالى، وأن الــضروريات الخمـسـة

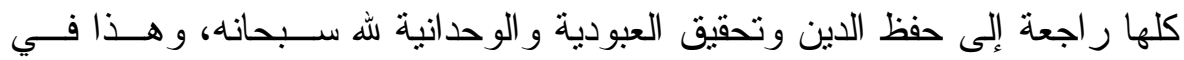
الثر ائع كلها.

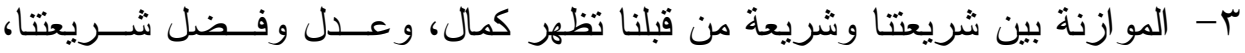
وتؤكد على أن من مقاصد شريعة الإسلام اليسر ورفع الحرج و المشقة، مما يعطي وني

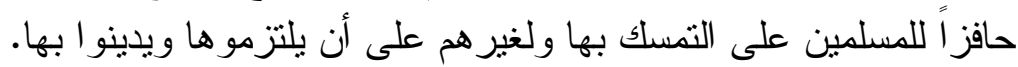

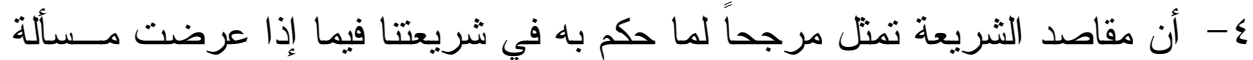

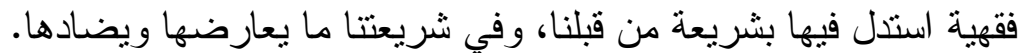
المسألة السابعة: علاقة المقاصد بالاستصحاب: أولاً: تعريف الاستصطحاب لغةً و اصطلاحاً: تعريف الاستصحاب لغة: هو طلب الصحة؛ يقال: استــصحبه إذا دعـــاه إلـى

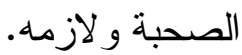

جاء في لسان العرب: "وكل شيء لازم شيء فقد استصحبه، واستصحبت الكتاب

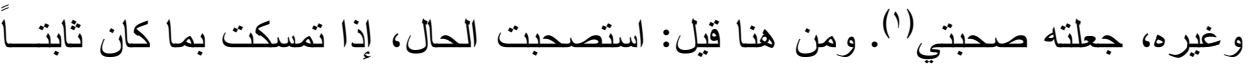

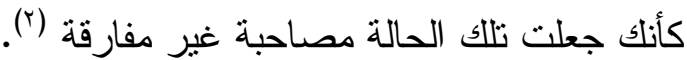

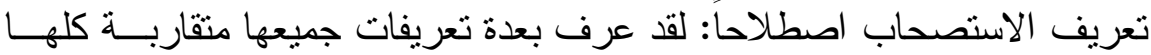

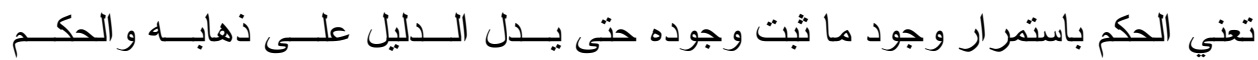

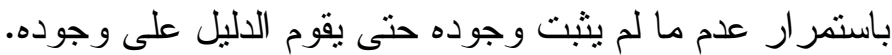

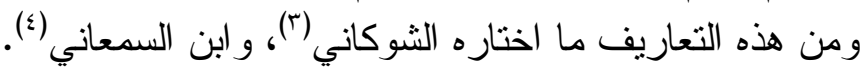

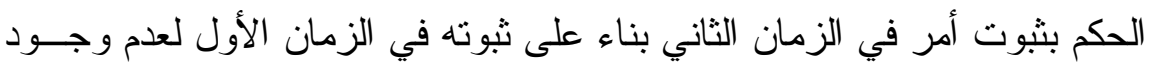

ما يصلح للتغيير (ن).

$$
\begin{aligned}
& \text { لسان العرب (1/.0r)، القاموس المحيط (1/99) مادة (صحب). }
\end{aligned}
$$

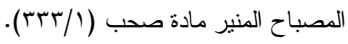

$$
\begin{aligned}
& \text { إرشاد الفحول (r/ }
\end{aligned}
$$

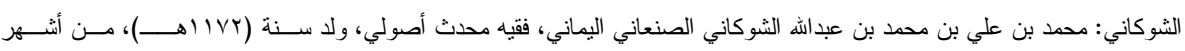

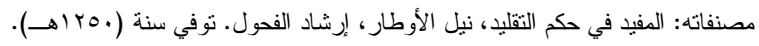

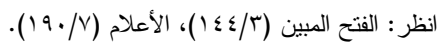

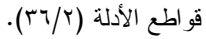

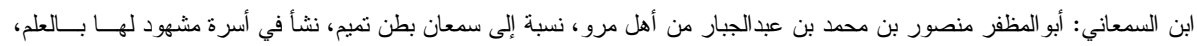

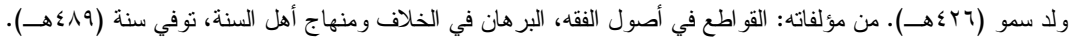




\section{ثانياً: حجية الاستصحاب:}

قبل بيان حجية الاستصحاب لابد من عرض صور الاستصحاب حتى يتبين لنــا

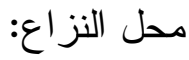
صور الاستصحاب:

1- استصحاب الحكم العقلي الثابت عند المعتزلة وهذا لا خلاف بين أهل السنة في أنه

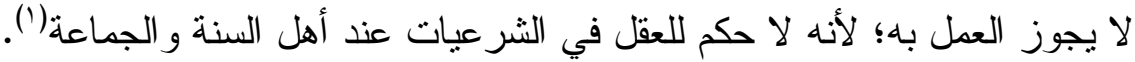

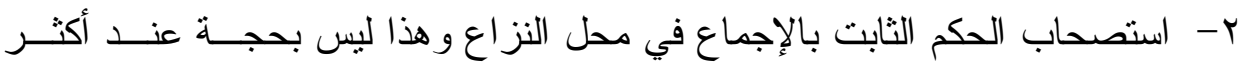

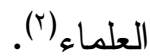

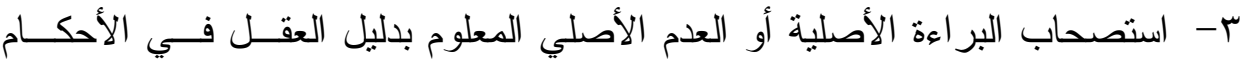

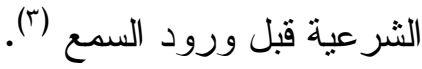
ع - استصحاب الحكم الذي دل الدليل الثرعي على ثبوته ودو امه، ولم يقم دليل علـى تغييره(£)

ه- استصحاب الدليل مع احتمال المعارض، إما تخصيصاً إن كان الدليل عامــاً و إمـــا

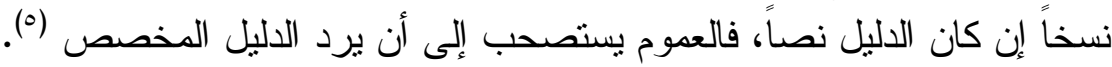

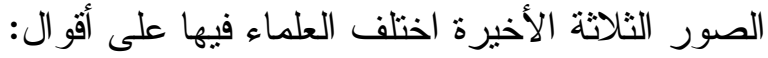
القول الأول:

أنه حجة مطلقاً سو اء كان الاستصحاب في الإثبات أو النفي، وسواء كان لأمسر

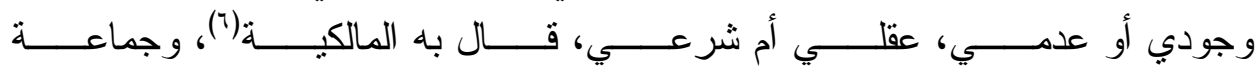

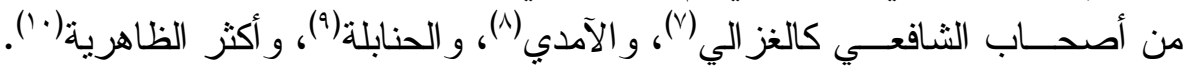

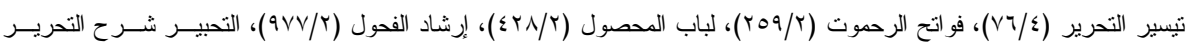

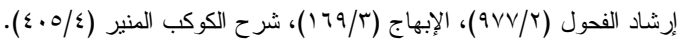

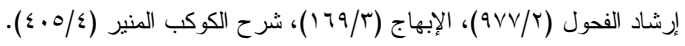

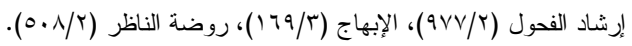

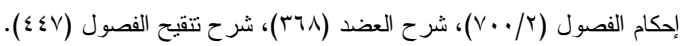

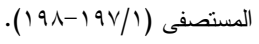

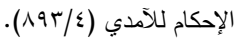

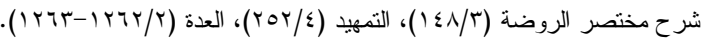




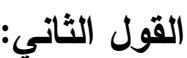

أنه ليس بحجة مطلقاً لا لإثبات أمر لم يكن ولا لإبقاء ما كان على ما كان. قــال

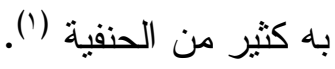

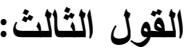

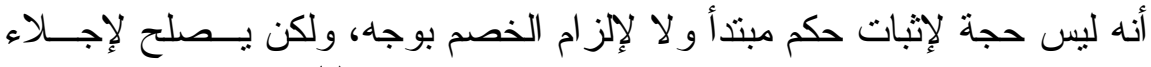

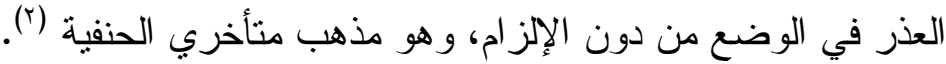

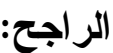

الذي يظهر لي -و الله أعلم- القول الأول وذلك لما يلي:

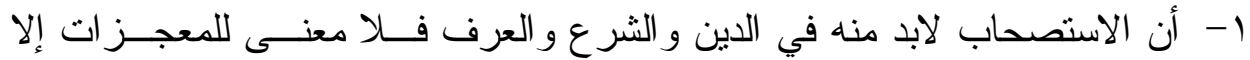

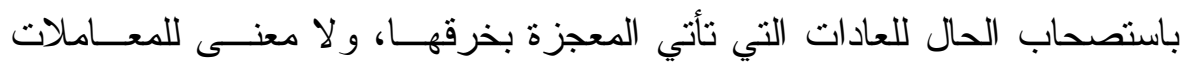

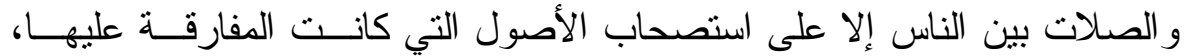

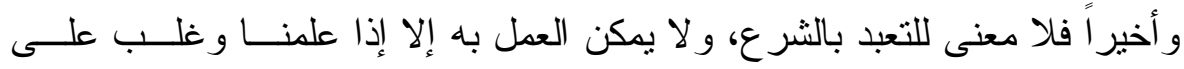

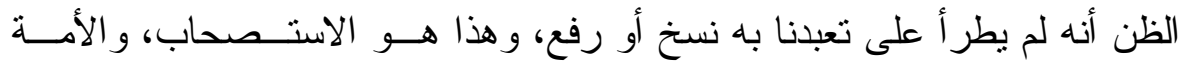

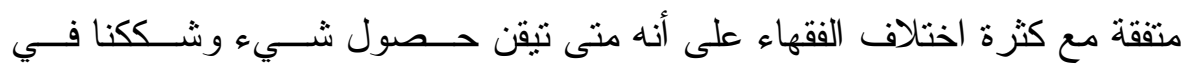

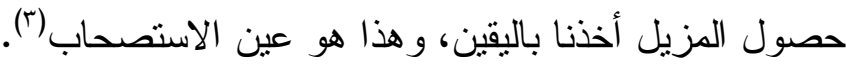

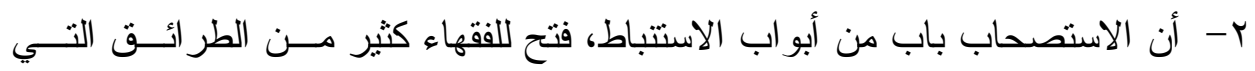
تجعهم يصدرون الفتاوى و الأحكام، ويفصلون الوقائع الطارئة.

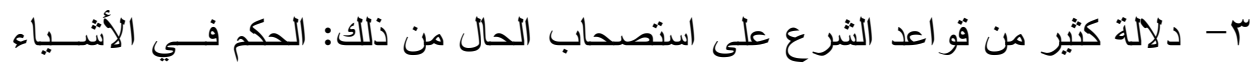

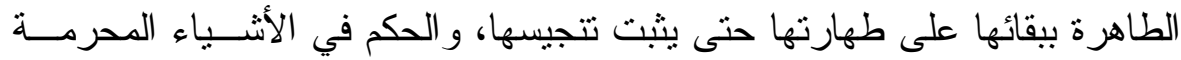

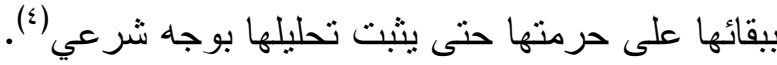

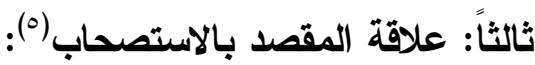

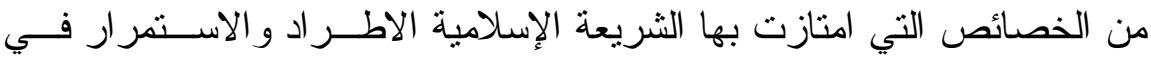

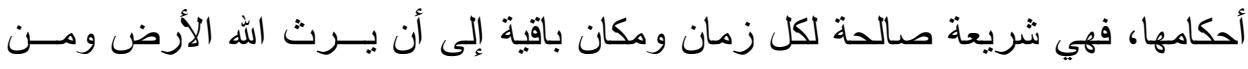

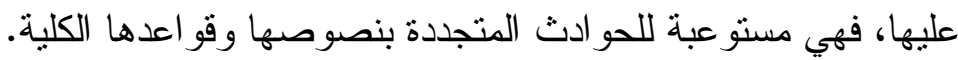

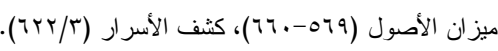

المر اجع السابقة.

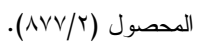

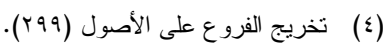

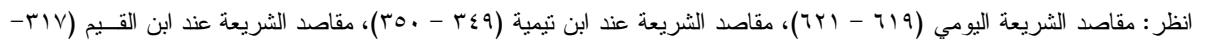




$$
\text { ويمكن إجمال علاقة المقاصد بالاستصحاب فيما يلي: }
$$

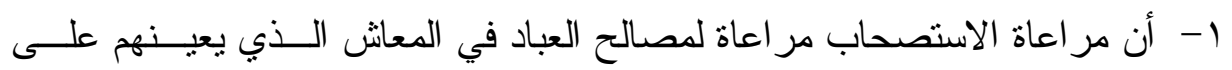

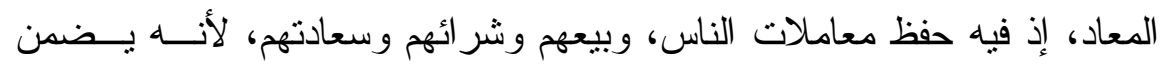
سلامة نظام المجتمعات و استقامتها. r- أن العمل بالاستصحاب فيه توسعة على المكلفين ورفع الحرج و الــضيق عـنهم

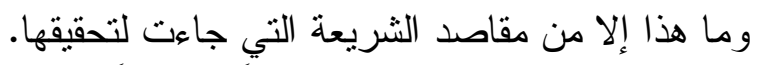

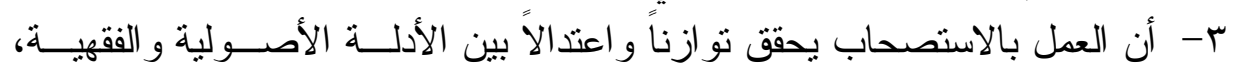

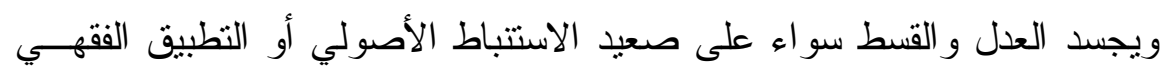
لأحكام الشريعة لاسيما فيما يتصل بحقوق الناس ومعلى ولاملاتهم. فالذي يظهر أن الاستصحاب راجع إلى الأدلة الأخرى وليس دليلاً مستقلاً. 
المبحث الثاني

علاقة المقاصد بالقو اعد الفقهية

ويتضمن خمسة مطالب:

المطلب الأول: علاقة المقاصد بقاعدة المشقة تجلب التبسير

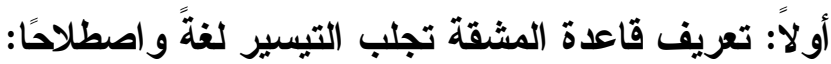

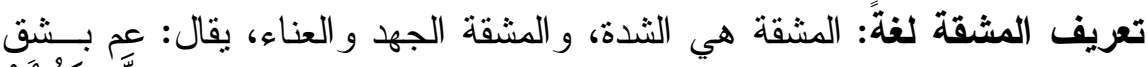

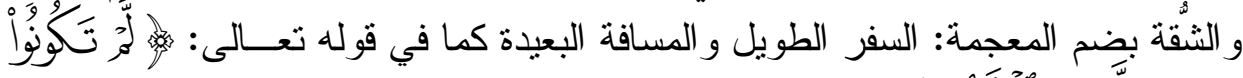

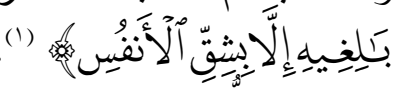

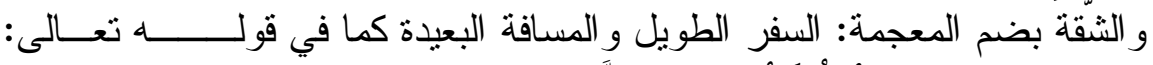

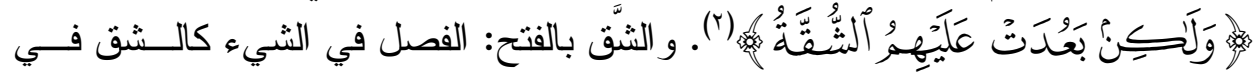
الجبل (r) (1) (2)

تعريف تجلب لغةً: جلب الثيء سوقه و المجيء به من موضع إلى موضع (ء).

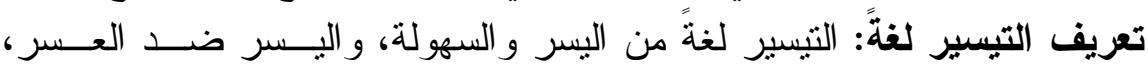

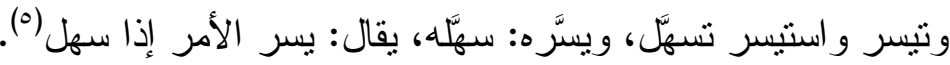
معنى المشقة تجلب التيسير:

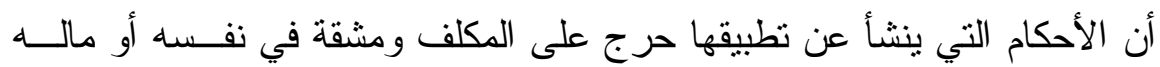

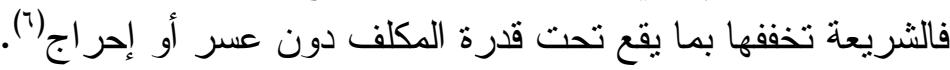
ثانيًا: علاقة المقاصد بقاعدة المشقة تجلب التيسير:

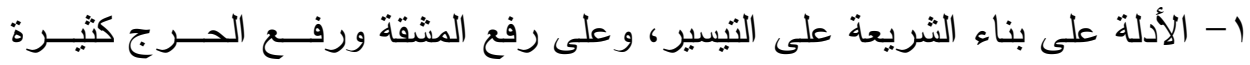

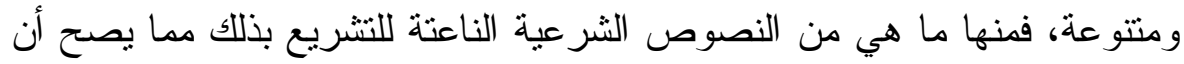

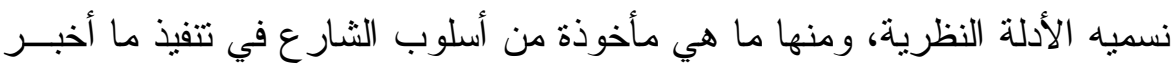
به من ابتتاء الثريعة على اليسر ورفع الحرجه ومنه

$$
\begin{aligned}
& \text { جزء من الآية (V) من سورة النحل. } \\
& \text { جزء من الآية (r؟) من سورة التوبة. }
\end{aligned}
$$

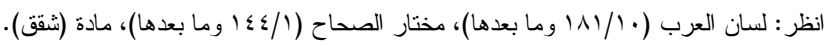

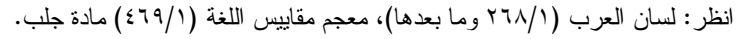

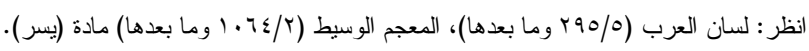

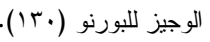




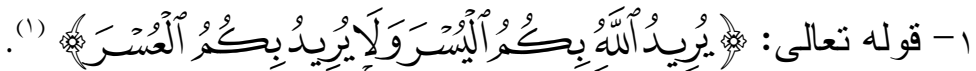

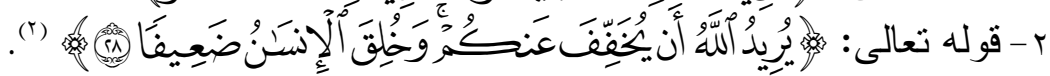

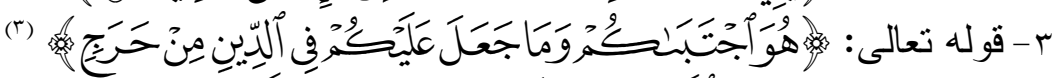

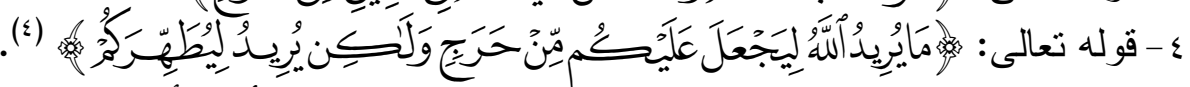

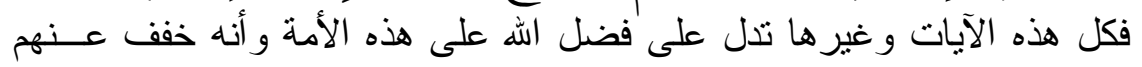

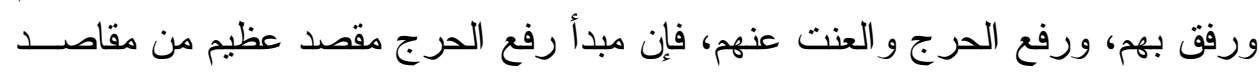
الثريعة ومما ميز الله به هذه الأمة عن غير ورف لها من الأمح السابقة. من السنة: من

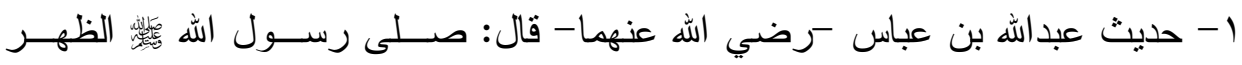

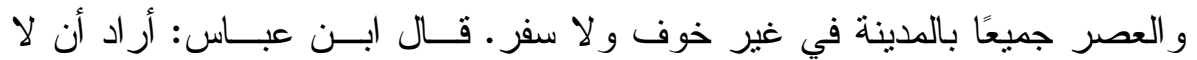

$$
\text { يحرج أمته (ن) }
$$

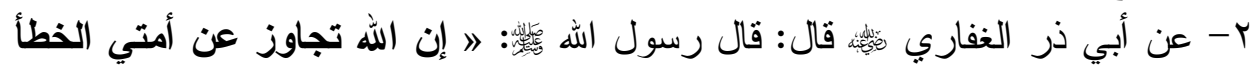

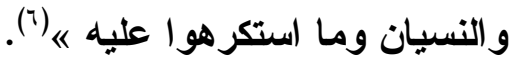

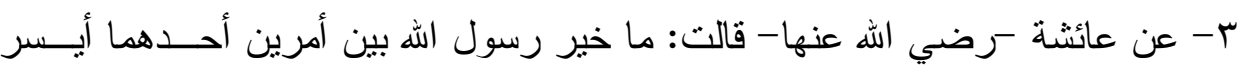

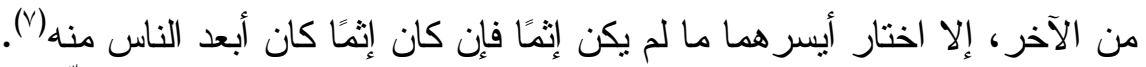

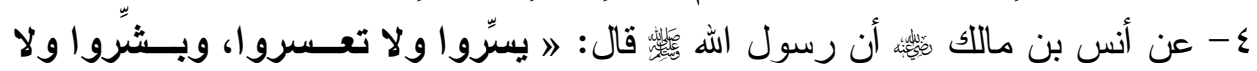

$$
\text { تنفروا « }
$$

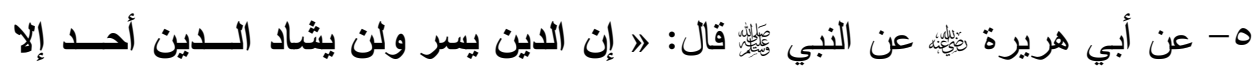

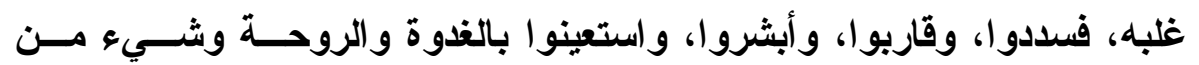

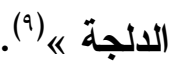

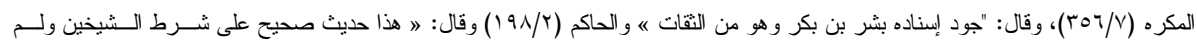

يخرجاه".

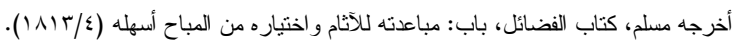

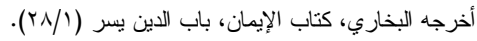




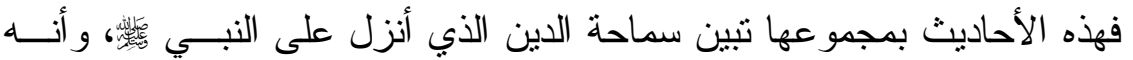
دين يسر وتقر مبدأ رفع الحرج الذي يعد مقصد عظيم من مقاصد الثريعة.

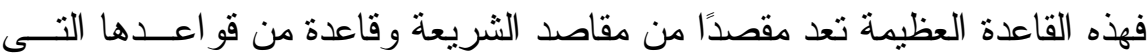

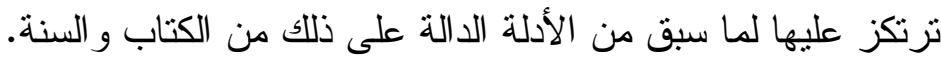

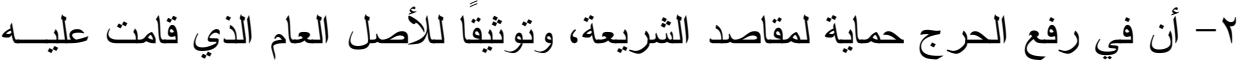
الثريعة من جلب المصالح ودفع المفاسد.

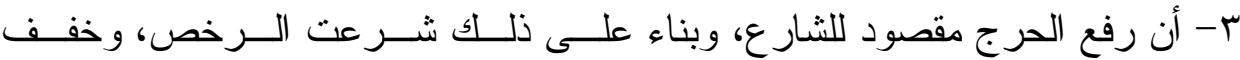
لأصحاب الأعذار في كثثر من الأحكام.

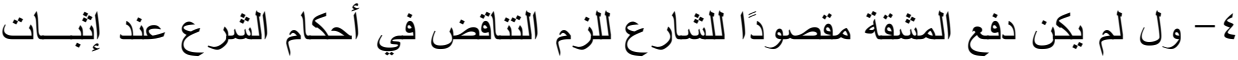

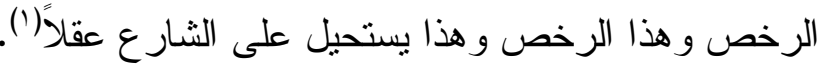

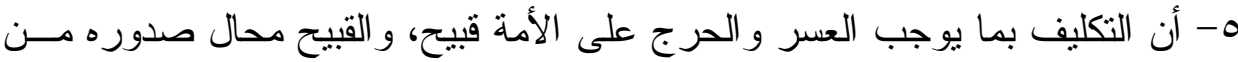

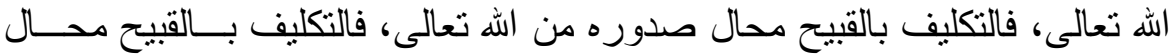

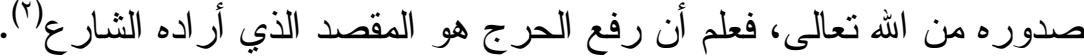

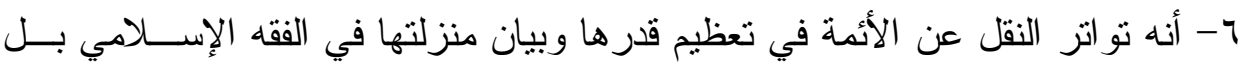

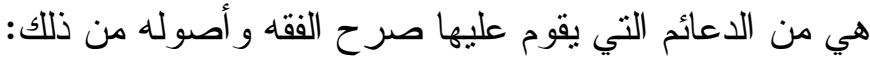

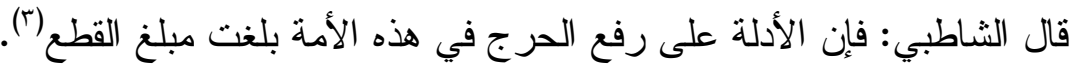

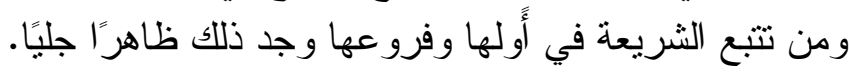

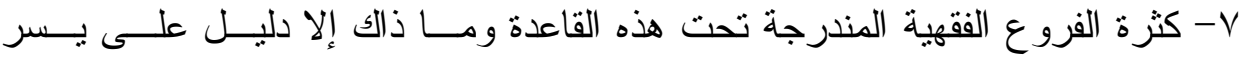

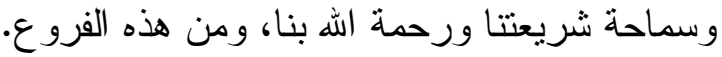

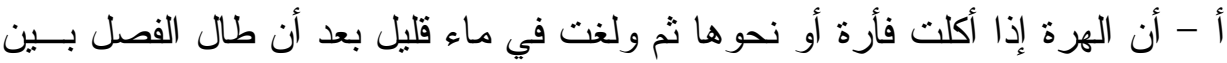

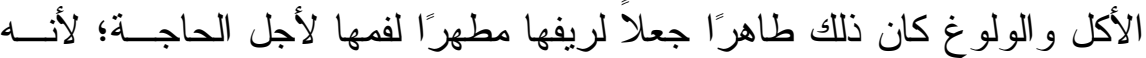

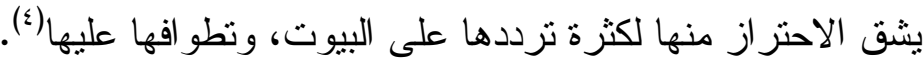

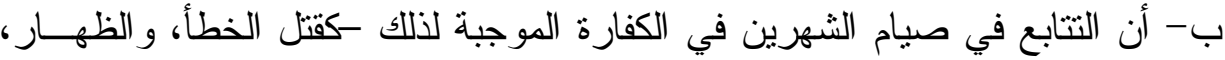

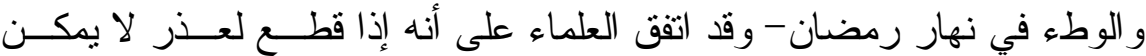

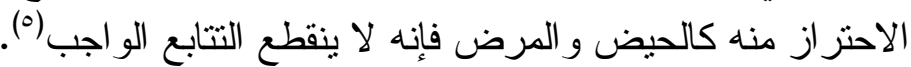

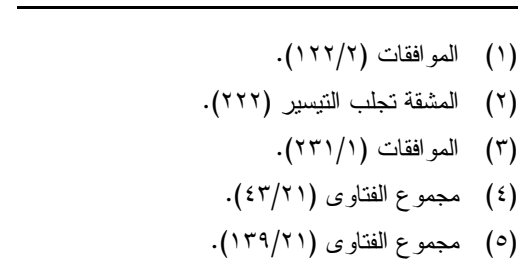




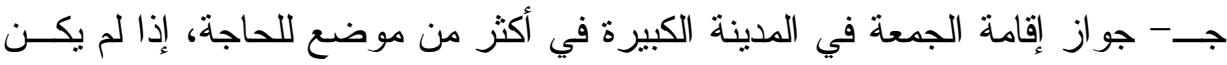

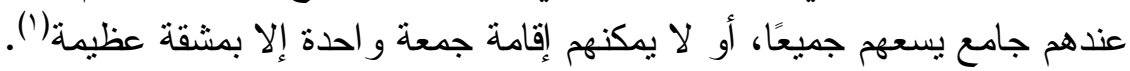

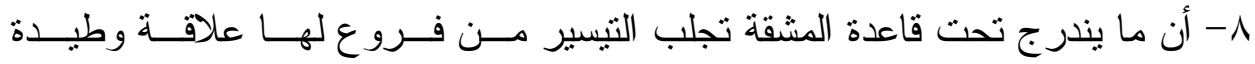
بالمقاصد الشرعية من أمتلة ذلك:

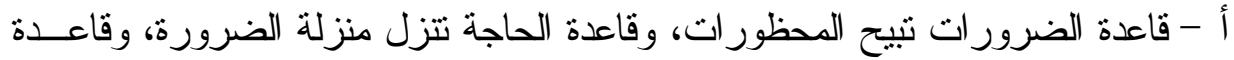

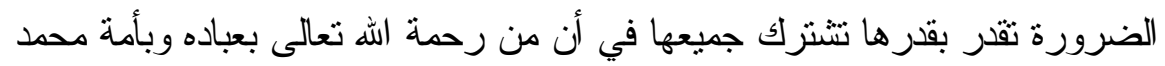

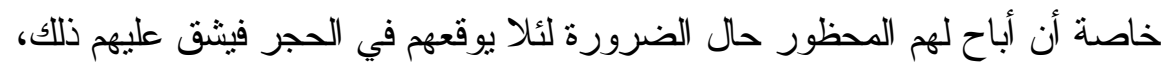

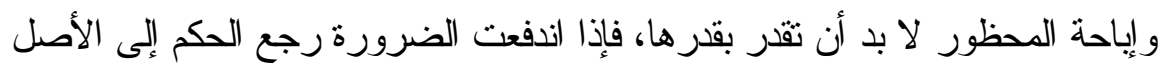
في تحريم ذلك المحظور •

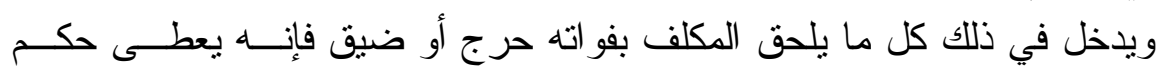
الضرورة ليرتفع الحرج و الضيق، وفي هذا يتجلى عظم سماحة شريعة الإســلام في مر اعاة المكلفين. قال العز بن عبدالسلام: "الضرورات مناسبة لإباحة المحظورات جلبًا لمصالحها

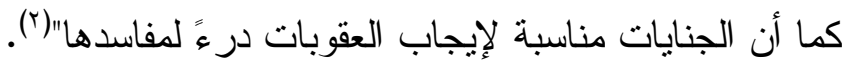

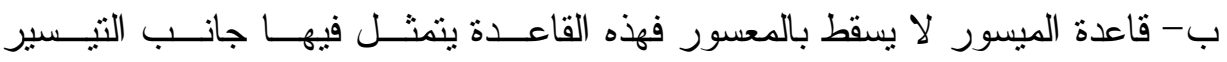

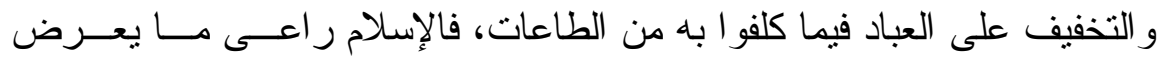

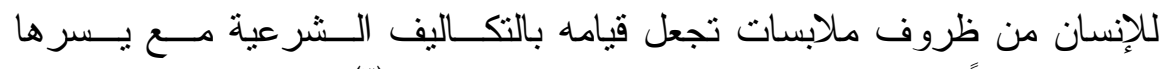

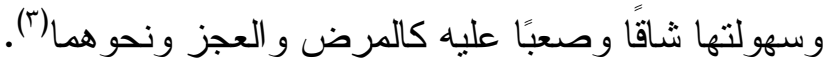

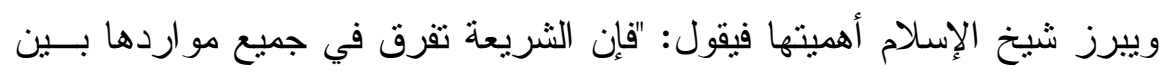

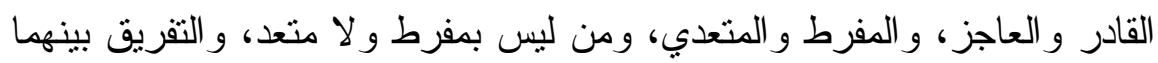

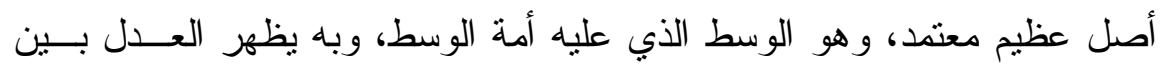

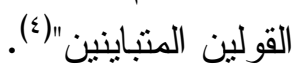

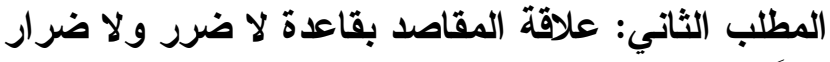

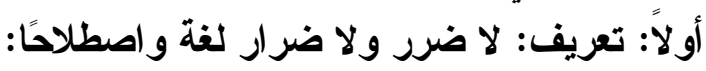

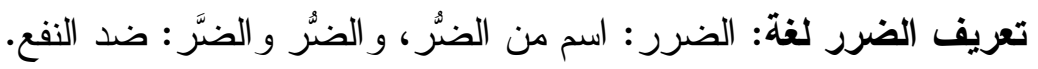

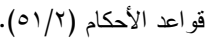

القو اعد الفقهية الكبرى للسدلان (r) (YII).

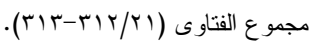


و الضرر : الضيق وسوء الحال، و اضطره إليه أحوجه و ألجأه(').

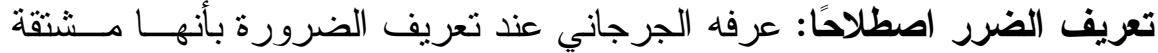
من الضرر وهو النازل مما لا دفع فيه. معنى قاعدة: لا ضرر ولا ضر ضرار

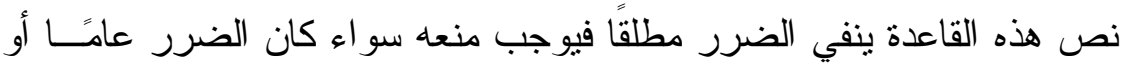

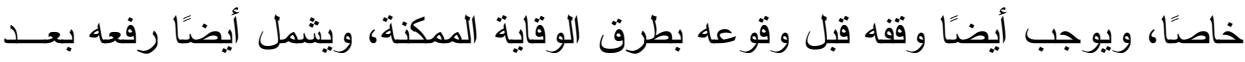

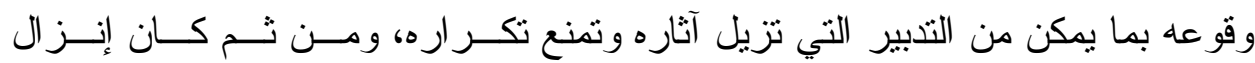

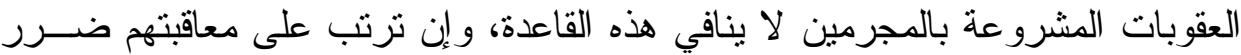

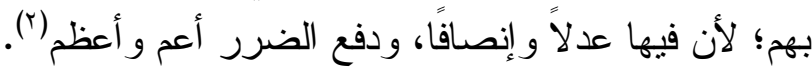

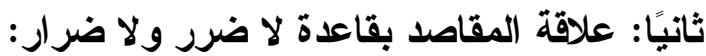

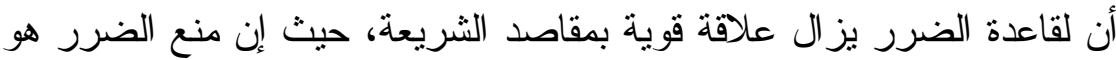

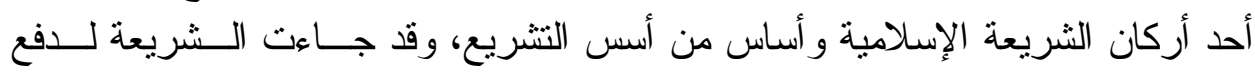
المفاسد عن المكلفين في أنفسه و أمو الهم، و أعر اضهم و عقو لهم و أنسابهم.

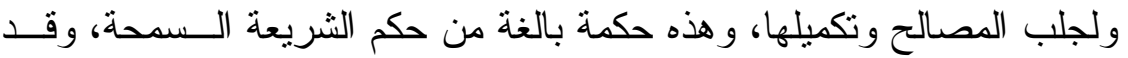

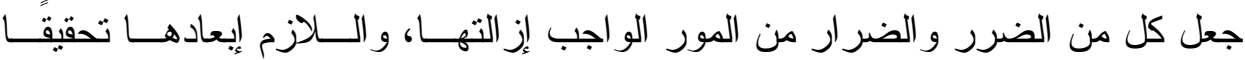
لـصالح الناس ومقاصد الثريعة. قال الثشاطبي: "إن الضرر و الضرار مبثوث منعه في الثريعة كلها فــي وقــائع

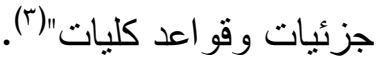

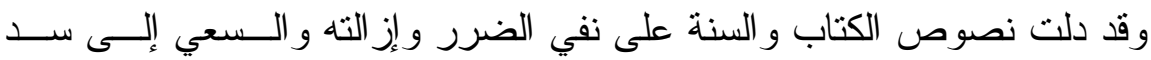
أبو ابه ومنافذ حصوله:

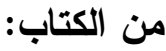

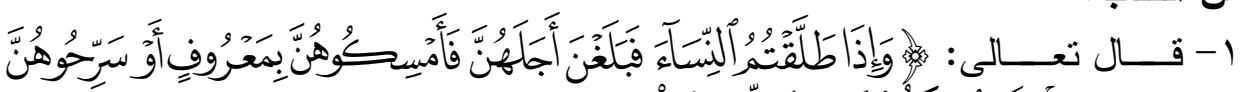

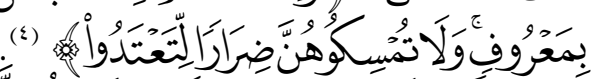
r- قالَ نعالى

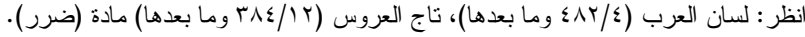

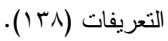

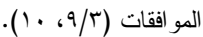

$$
\begin{aligned}
& \text { جز ع من الآية (آTr) من سورة البقرة. }
\end{aligned}
$$

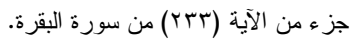


من السنة:

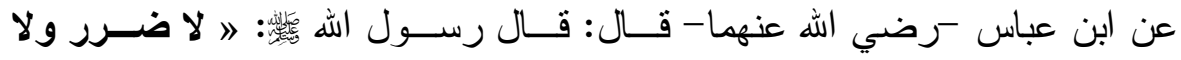
ضر اربه (')

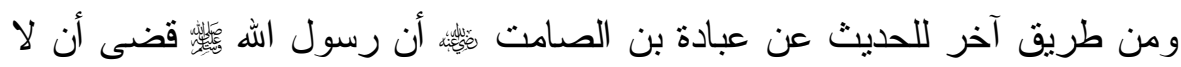

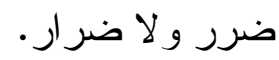

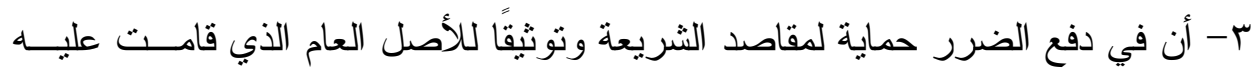

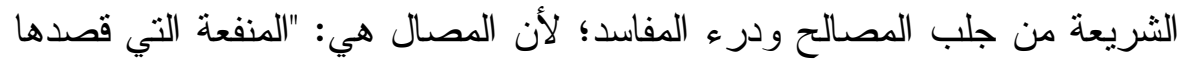

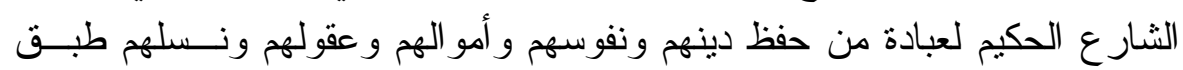

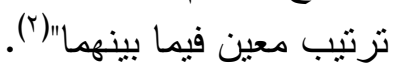

وكل ما يؤدي إلى الإخلال بو احد منها فهو مضرة يجب الجب إز التها ما أمكن.

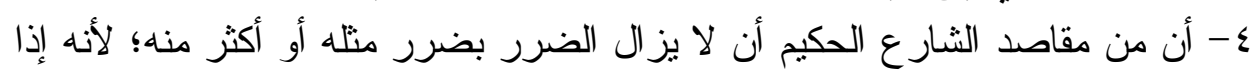

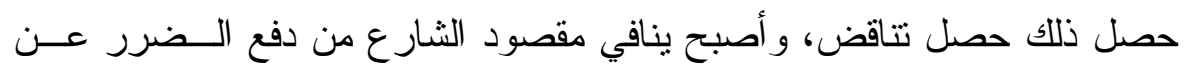
المكلفين و الشرع الحكيم منزه عن ذللك.

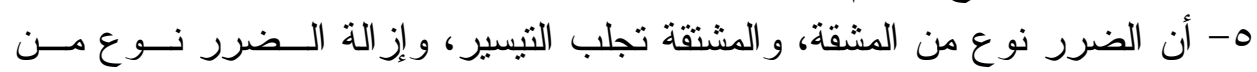

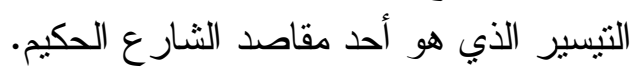

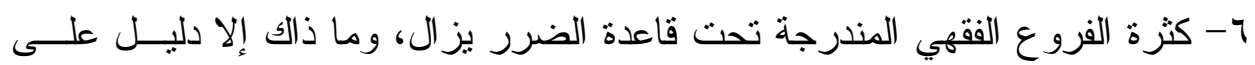

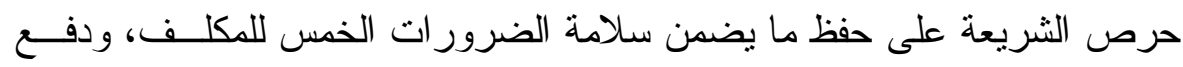
الضرر قبل وقوعه، ورفعه بعد وقو عه، ومن هذه الأمثنة:

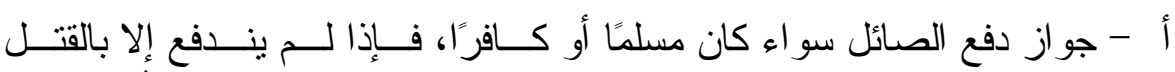

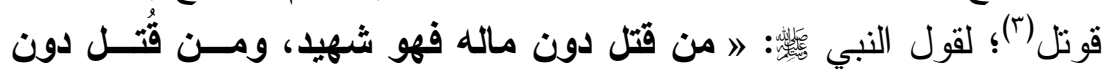

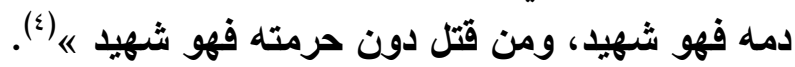

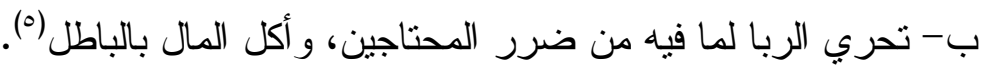

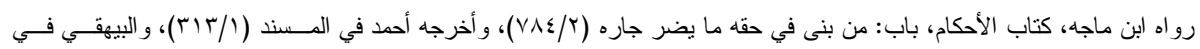

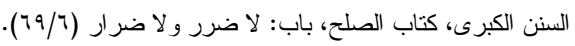

ضو ابط المصلحة للبوطي (rT) (rr).

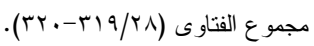

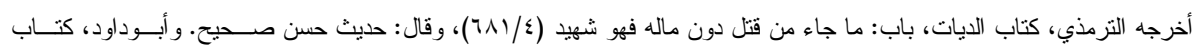

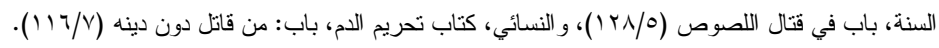


ج- لا يجوز البناء في طرف المسلمين إذا كان هذا البناء يضيق الطريق ويضر بالمسلمين حتى ولو كان مسجدًا (').

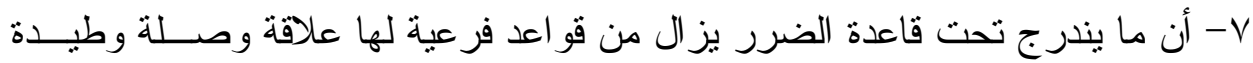

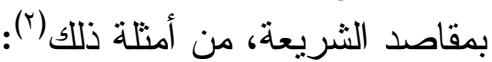

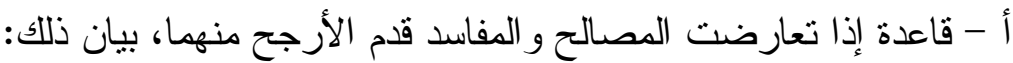

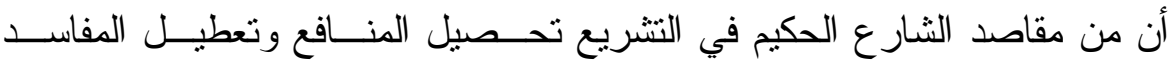

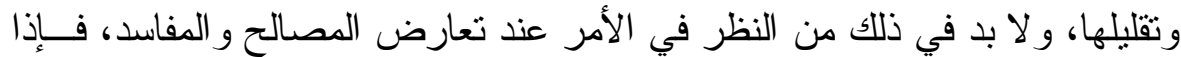
تعارضت في فعل واحد، فننظر إلى الغالب فيه منهم فإن كانت المفاسد هي الغالبة فئن

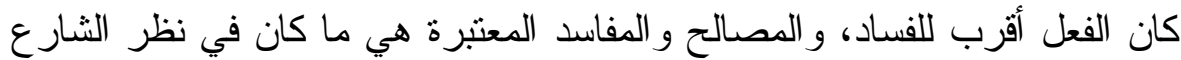
مصلحة أو مفسدة وليس ما كان مبني على الهوى و التشهي.

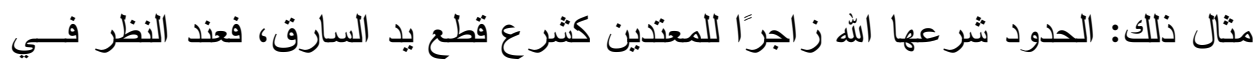

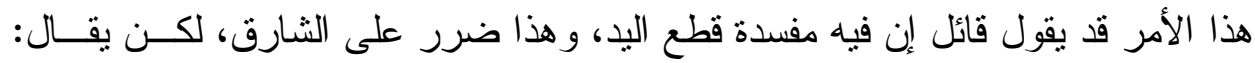

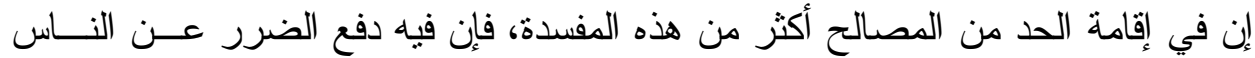

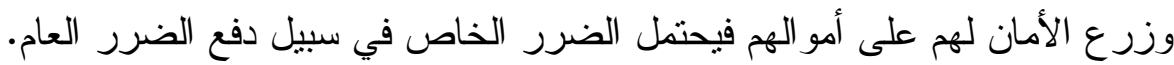

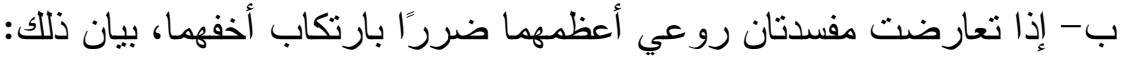

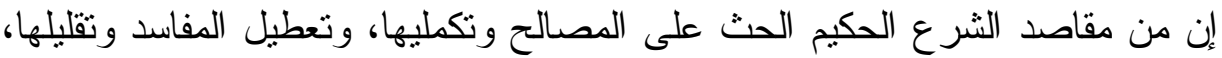

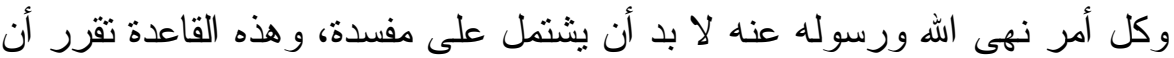
ما لم يمكن تعطيل مفسدته بالكلية، فالواجب السعي إلى تقليلها قدر الإمكان وهــــا ما تقيده مقاصد الشربعة.

المطالب الثالث: علاقة المقاصد بقاعدة ملفة العادة محكمة أولاً: تعريف العادة محكمة لغة والب اصطلاحًا:

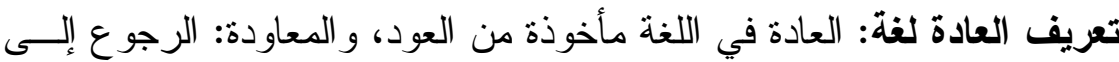

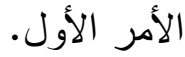
و العادة: الديدن يعاد عليه، وجمعها، و عادات، و عو ائد.

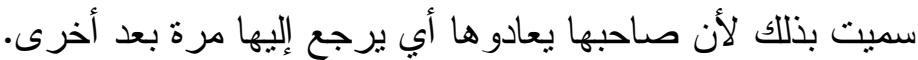

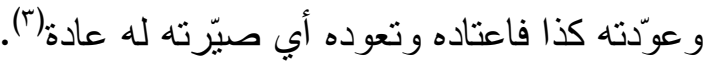


تعريف العادة اصطلاحًا: عرفها ابن أمير الحاج: الأمر المتكرر من غير علاقــة

عقلية (1).

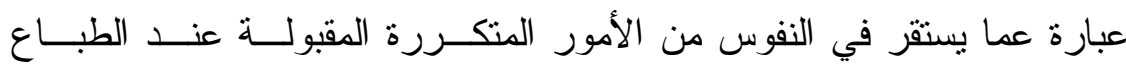

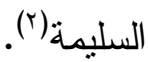

معنى قاعدة العادة محكمة:

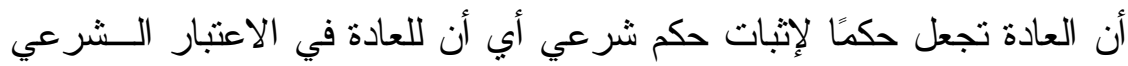

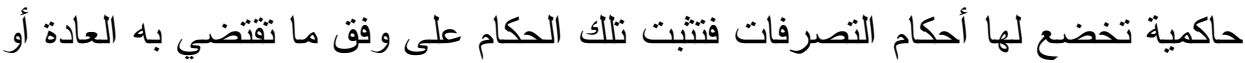

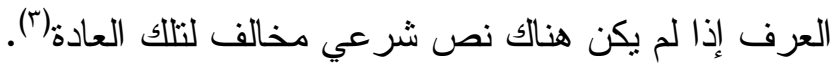
ثانيًا: علاقةة المقاصد بقاعدة العادة محكمة:

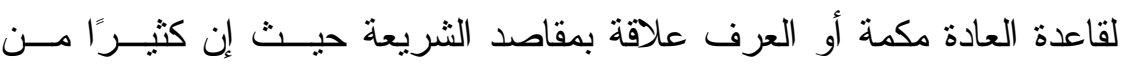

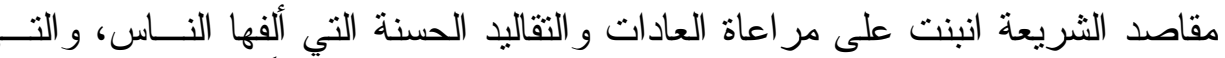

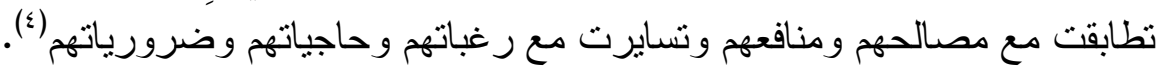

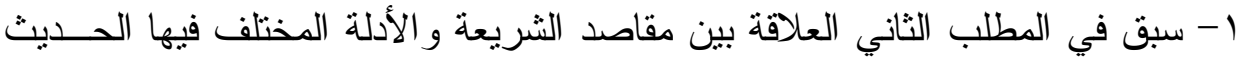
عن علاقة المقاصد بالعرف باعتباره أحد الدلة التي يستتد إليها.

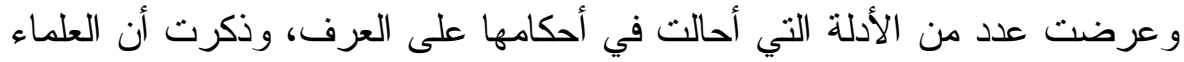

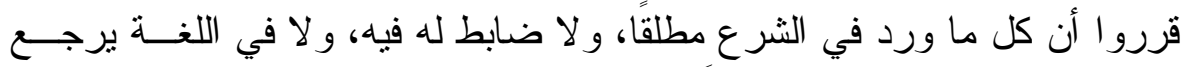

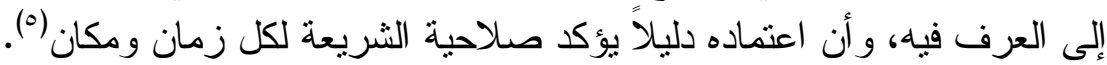

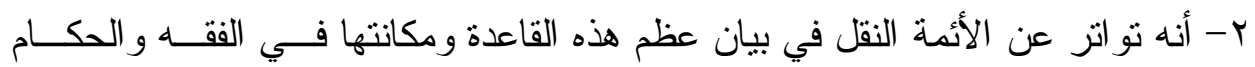
الثر عية من ذلك:

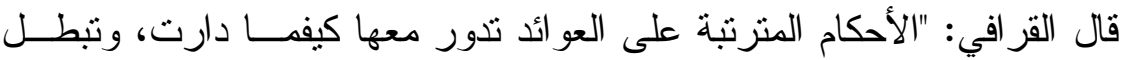

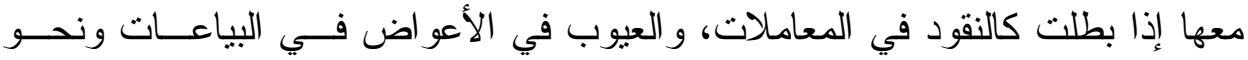

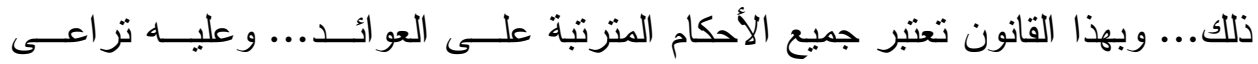

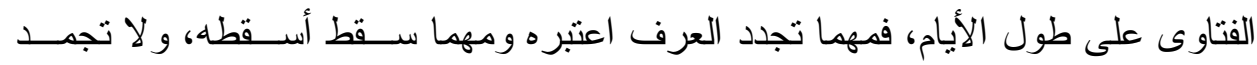

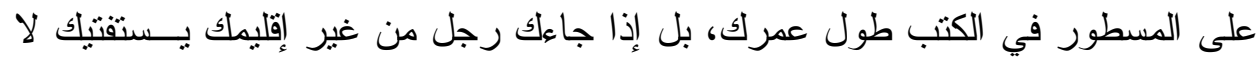

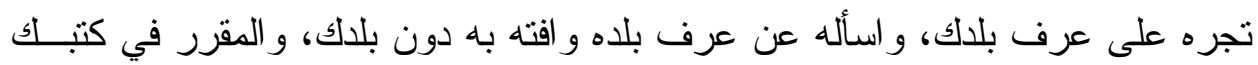


فهذا هو الحق الو اضح، و الجمود على المنقولات أبدًا ضـلال في الدين، وجهل بمقاصـــ

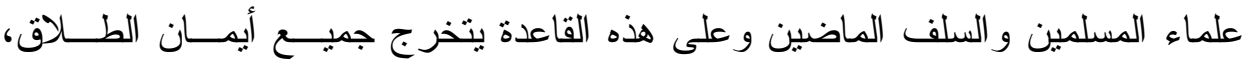

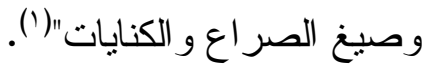
وذكر الثاطبي قريبًا منه (؟).

وما سبق بدل على مقدار احتر ام الفقهاء للعرف وفهمهم أن القو اعد الفقهية مـــا

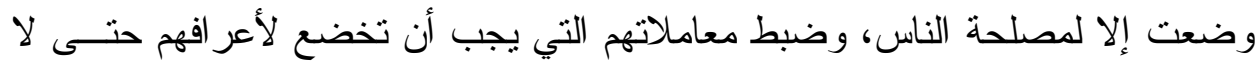
يجمد الفقه أمام ما يجد من الحو ادث بحسب اختلاف الأحو ال وتغير الأزمان (َ).

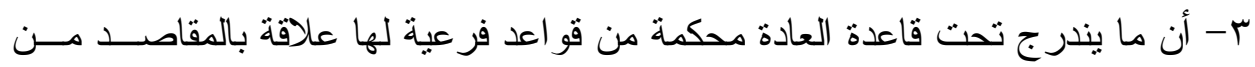
ذلك (₹)

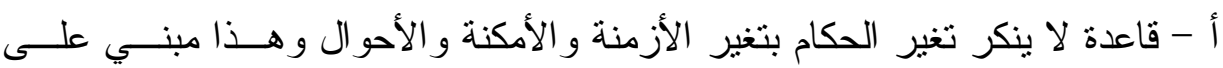

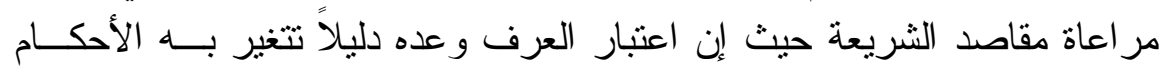

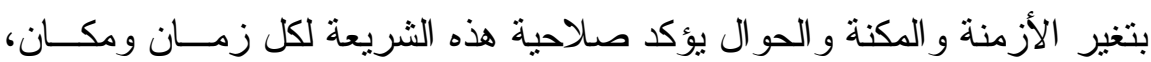

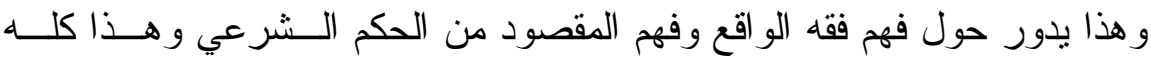
تحقيقًا لمقاصد الثر عية.

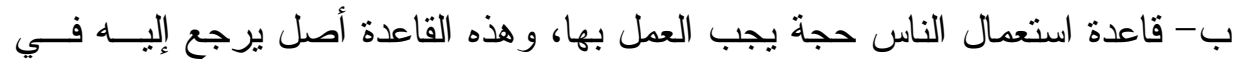

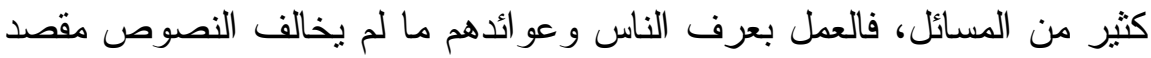

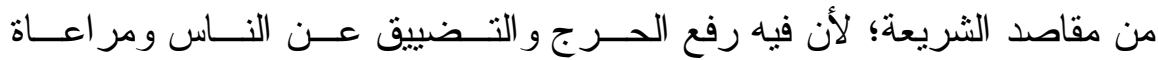

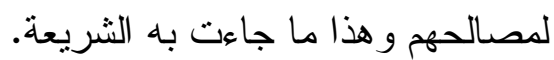

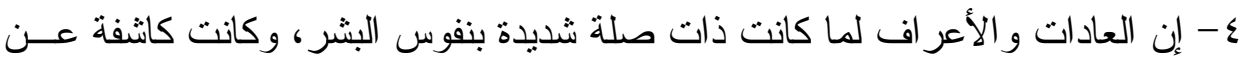

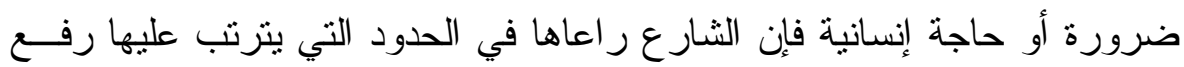

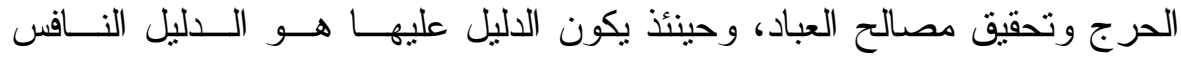

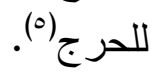

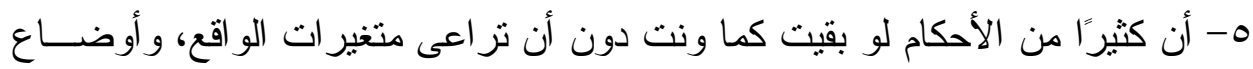

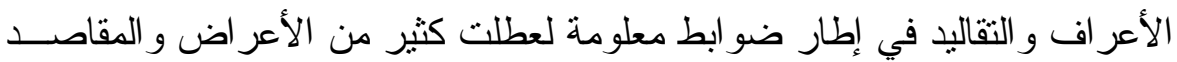

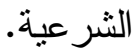

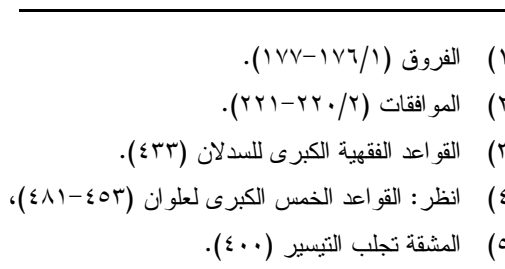

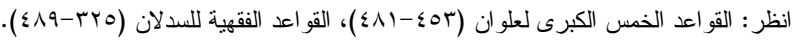




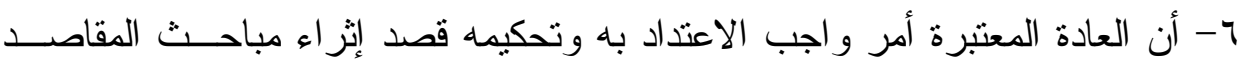

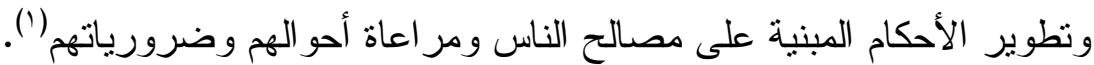

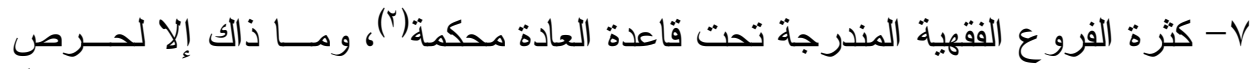

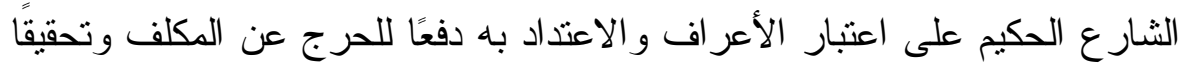
لمقاصد الشريعة، من الأمتلة:

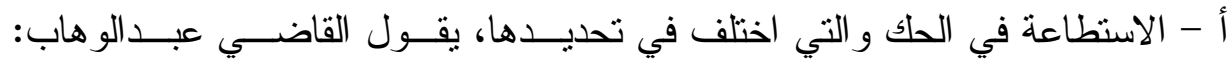

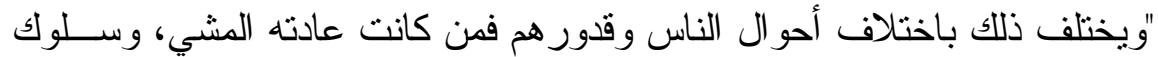

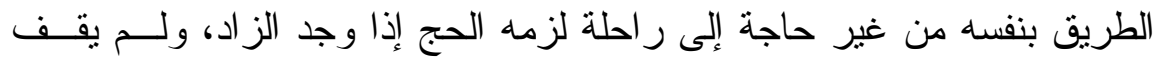

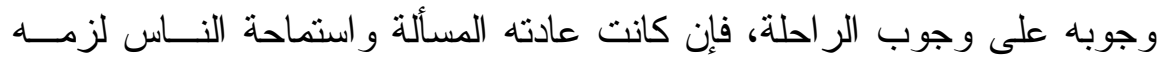

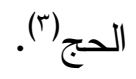

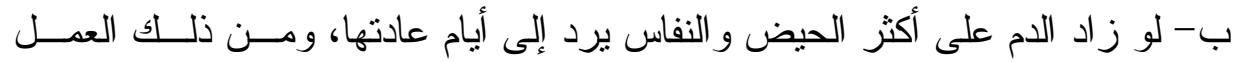

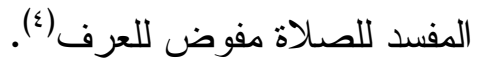

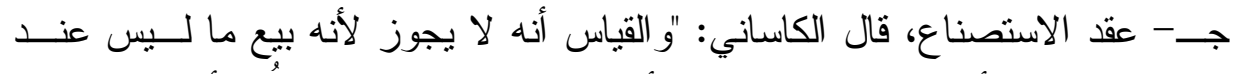

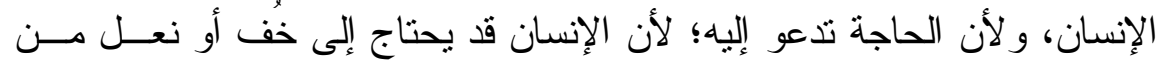

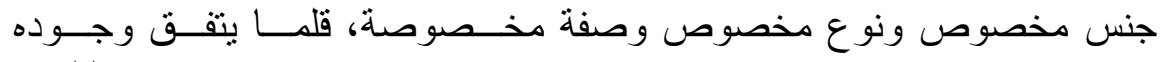
مصنو عًا فيحتاج إلى أن يُستصنع فلو لم يقع لوقع الحرج العظيم على الأمة" (ه).

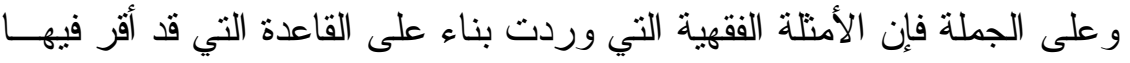

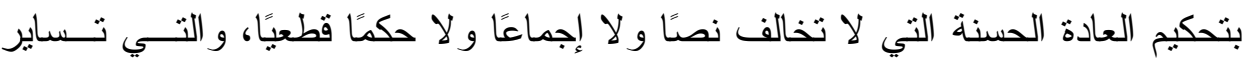

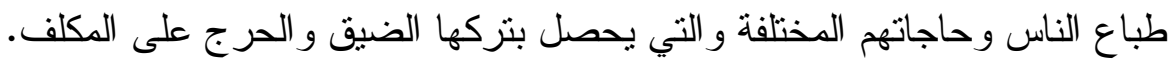

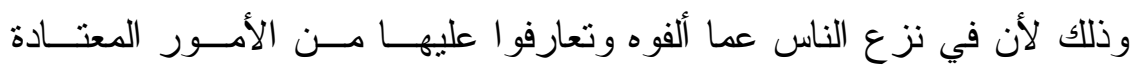

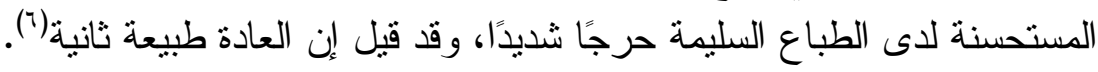
ومن هنا نص العلماء على وجوب النظر إلى المقاصد عن طريق النظر إلـى إلى

المكلفين، وجب أن ينظر في حكم العو ائد(').

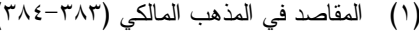

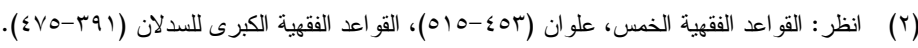

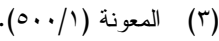

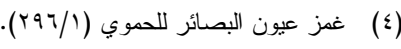

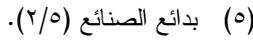

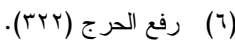

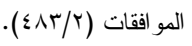


و النظر في هذه العو ائد هو من صميم الاستجابة إلـى المطالــب الـضرورية

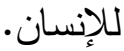
قال الثاطبي: "العو ائد الجارية ضرورية الاعتبار شرعًا، كانت شــرعية فــي

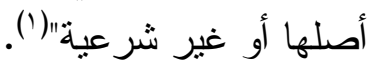
المطلب الر ابع: علاقة المقاصد بقاعدة اليقين لا يزول بالثئ بالثك

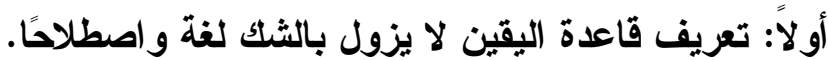

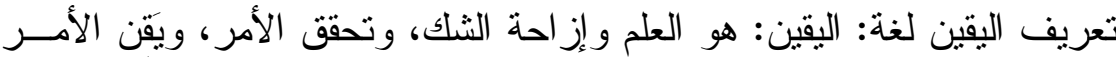

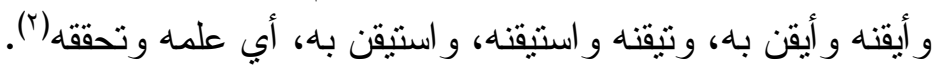

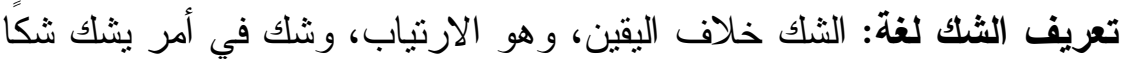
إذا التنس علبه وشك فيه(r). تعريف اليقين اصطلاحًا: اعتقاد الثيء بأنه كذا، مع اعتقاد أنه لا يمكن إلا كـــا،

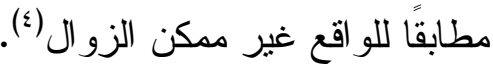

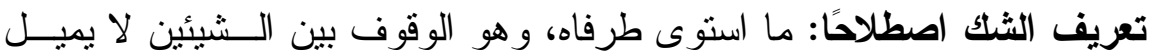

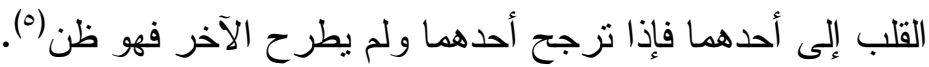

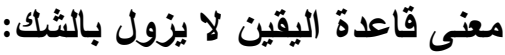

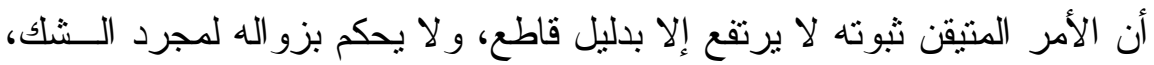

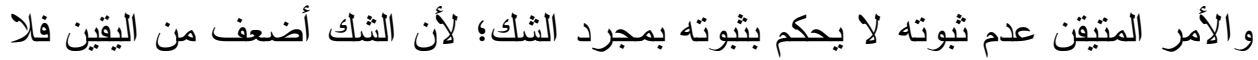

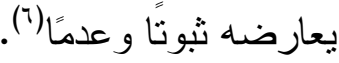
ثنانيًا: علاقة المقاصد بقاعدة اليقين لا يزول بالثالثك:

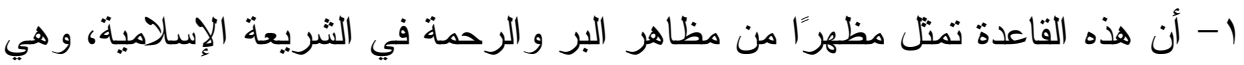

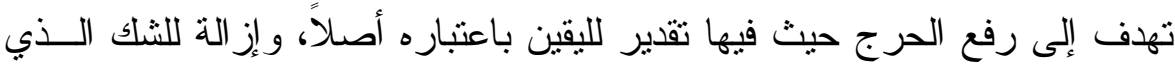

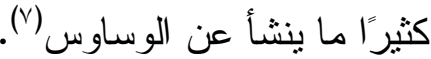

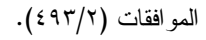

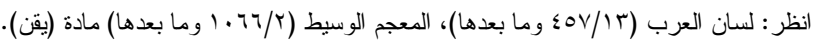

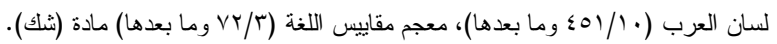

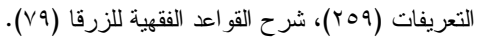

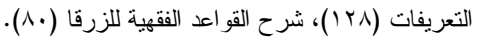

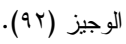

القو اعد الفقهية الكبرى للسدلان (9^). (9). 
Y- مقصد اليقين ورفع الثكك يتمنل في تكليف الإنسان بما في وسعه، وربما يقر عليــه، إذ

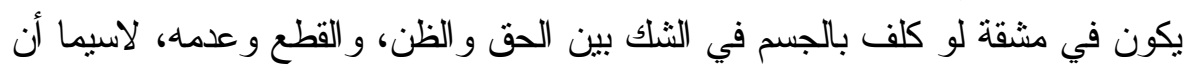

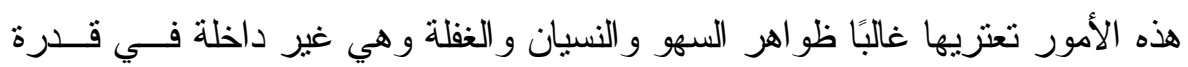

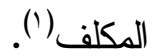

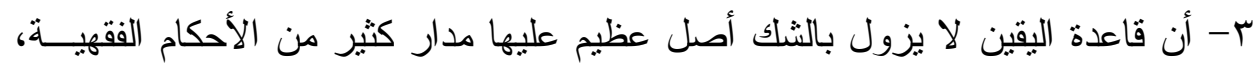

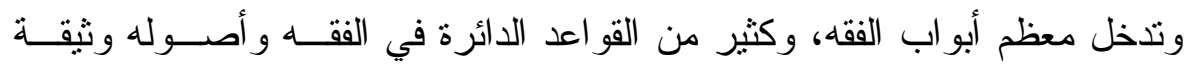
الصلة بها بل هي ناشئة عنها.

وقد دل على اعتبار ها الاعتداد بها الكتاب و السنة و الإجماع، من ذللكا. (؟): من الكتاب:

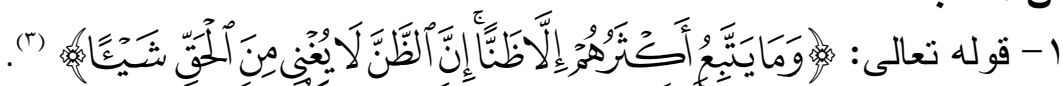

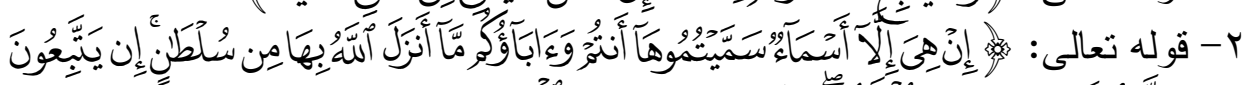

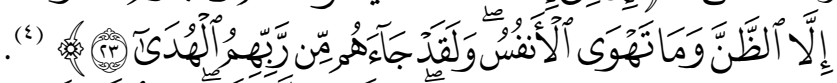

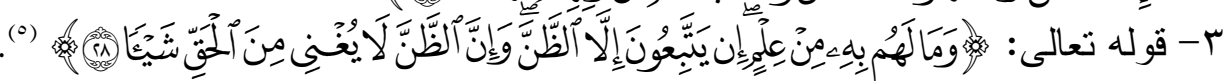

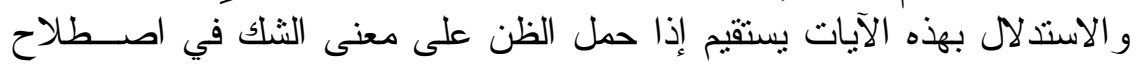

(الفقهاء) (؟) من السنة:

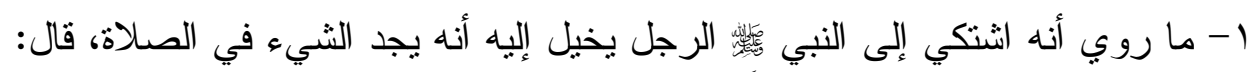

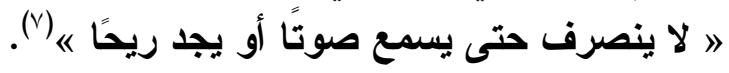

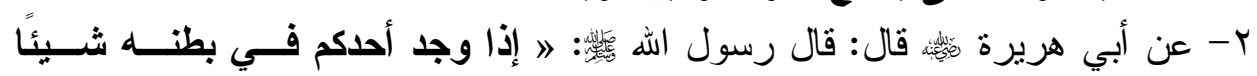
فأثكل عليه أخرج منه شيء أم أم لا، فلا يخرجن من المسجد حتى يسمع صوتًا أو أو

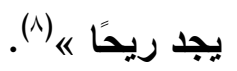

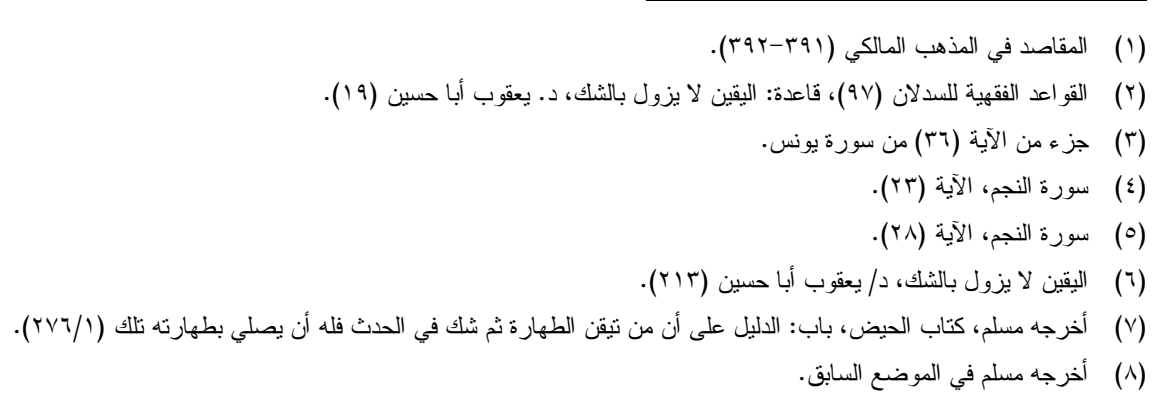




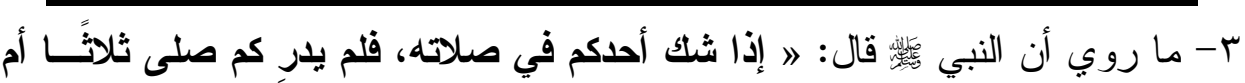

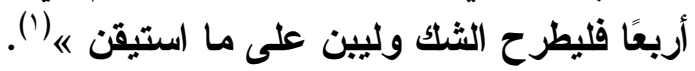

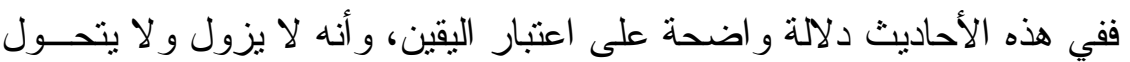
بمجرد الثك.

الإجماع: الإجزاع

انعقد إجماع الفقهاء على أصل العمل بهذه القاعدة، وإن اختلفــو ا فــي بعــ

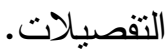

قال القر افي: "هذه قاعدة مجمع عليها، وهي أن كل مشكوك فيه يجعل كالمعـدوم

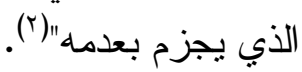

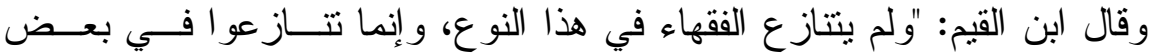

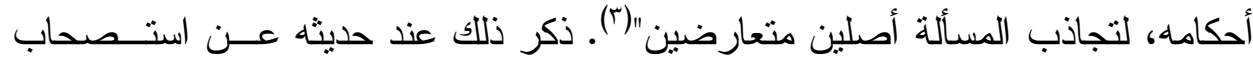
الوصف المثبت للحكم حتى يثبت خلافه.

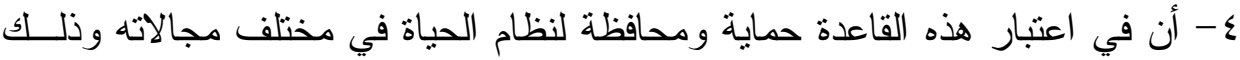

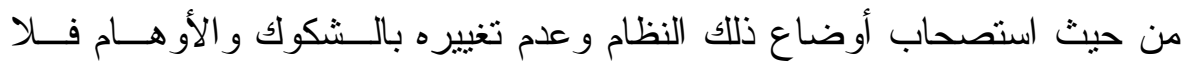

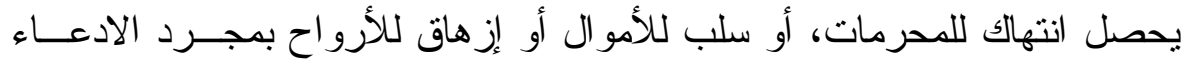

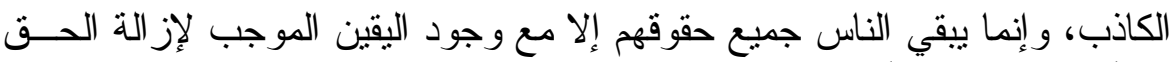
حفظًا للحقوق وصونًا لعور اتهم و أنفسهم.

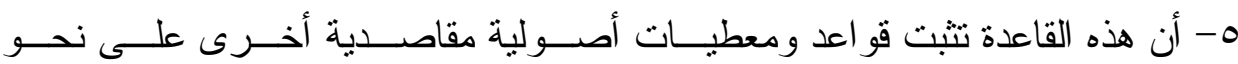

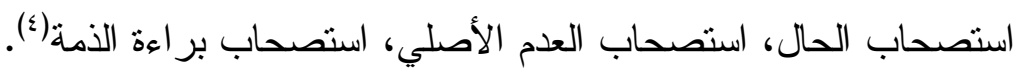

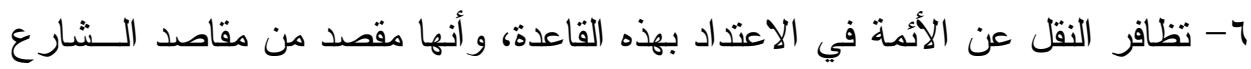
الحكيم من ذلك:

قال السرخسي: "إن التمسك باليقين وترك ذالمشكوك فيه أصل في الشرع"(ه).

$$
\begin{aligned}
& \text { أخرجه مسلم، كتاب المساجد ومو اضع الصلاة، باب السهو في الصلاة و السجود له ( (1/. ؛ ). } \\
& \text { الفروق (11/1) (11). } \\
& \text { إعلام الموقعين (1) (1)/ (1)/ (1). }
\end{aligned}
$$

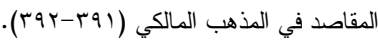

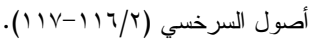

السرخسي: محمد بن أحمد بن أبي سهل، المعروف بشمس الأمة السرخسي، نسبة إلى بلد عظيم بخر اسان، وهو أحد أئمة الحنفية، مـن

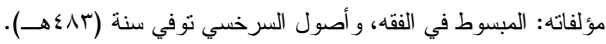

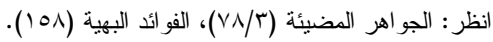




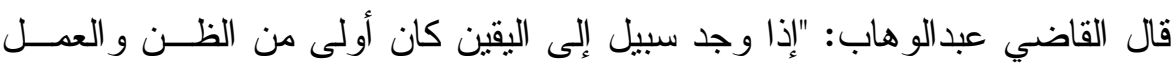

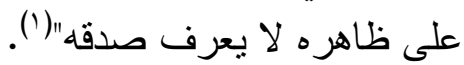
قال القر ابي: "هذه قاعدة مجمع عليها وهي أن كل مشكوك فيه يجعل كالعدم الـذذي

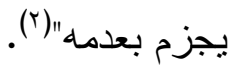

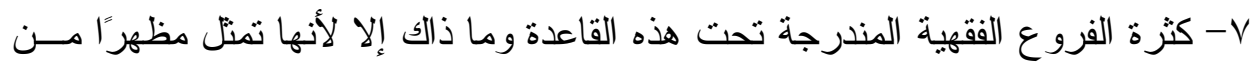

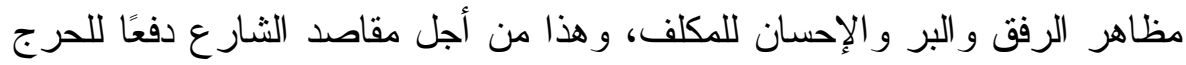

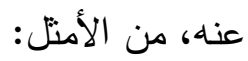

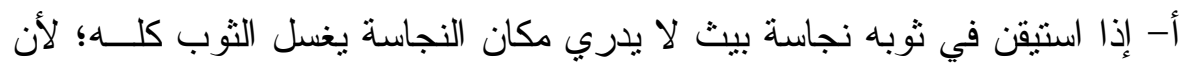
الثك لا يرفع المتيقن قبله (َ). ب- إذا شك في الماء هل إصابته نجاسة أم لاج بنى على يقين الطهارة.

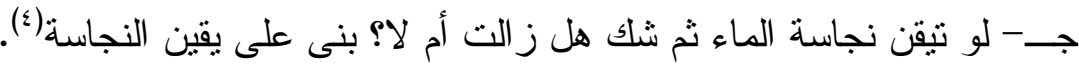

د- إذا شك في عدد الرضعات بنى على اليقين (०).

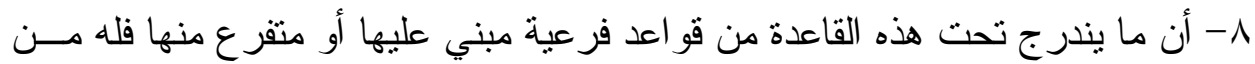

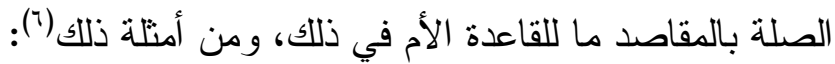

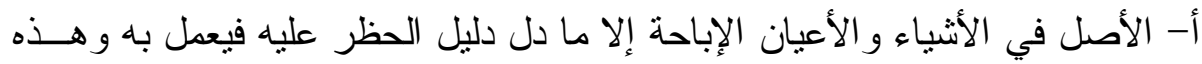

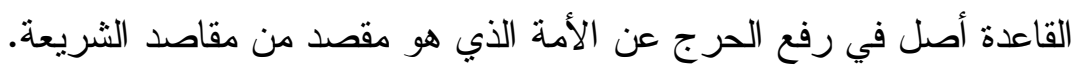

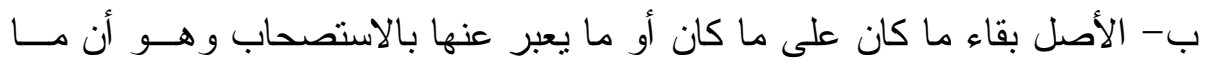

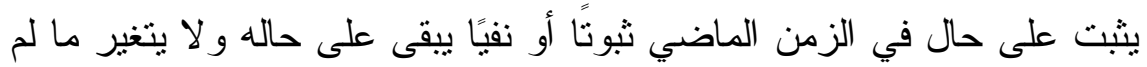

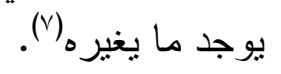

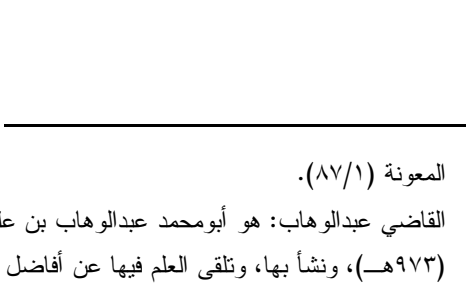

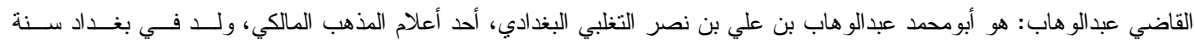

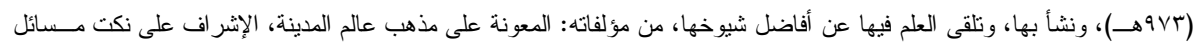

الخلاف، توفي سنة (r أشهـ).

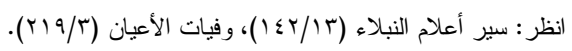

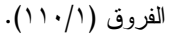

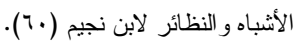

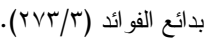

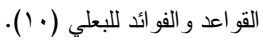

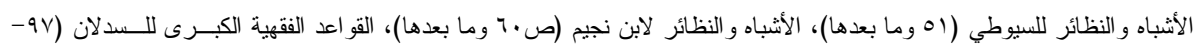

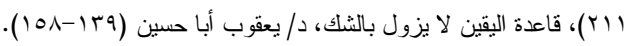


و هذه القاعدة تؤكد ما امتازت به شريعتا من الاطر اد و الاستمر ار في أحكامهــا

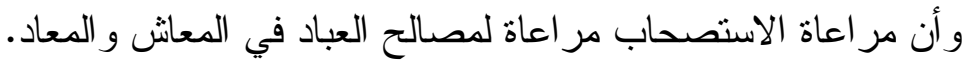

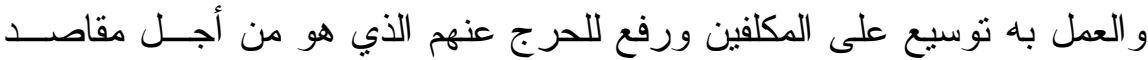
الثريعة التي جاءت لتحقيقها.

المطلب الخامس: علاقة المقاصد بقاعدة الأمور بمقاصدها

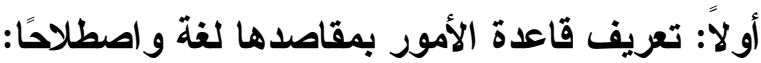

تعريف الأمور لغة: الأمور جمع أمر ويطلق في اللغة على معان الأملان عدة منها:

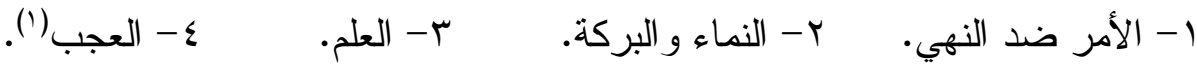

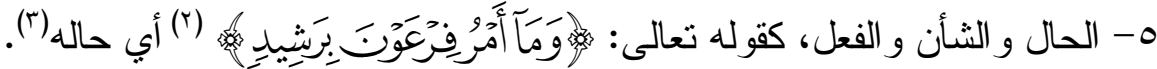

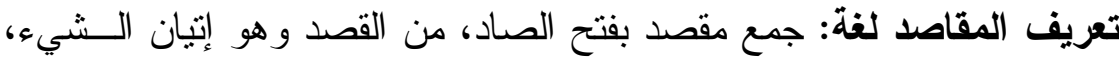

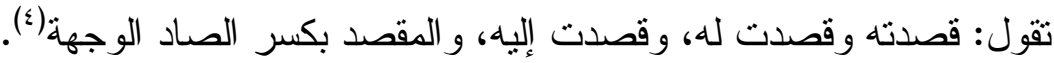
معنى قاعدة الأمور بمقاصدها:

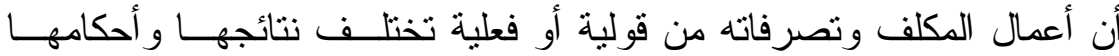

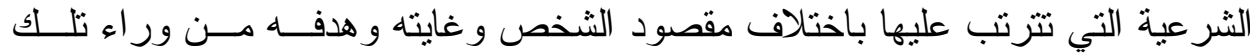

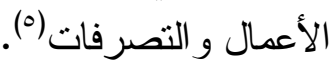
ثانيًا: علاقةة المقصد بقاعدة الأمور بمقاصدها

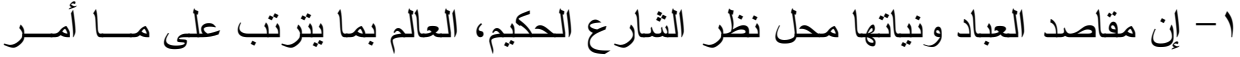

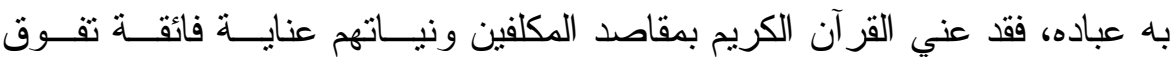

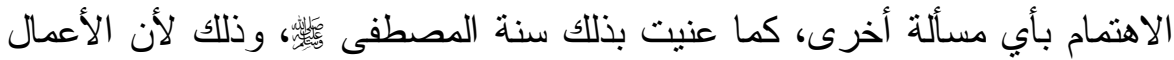

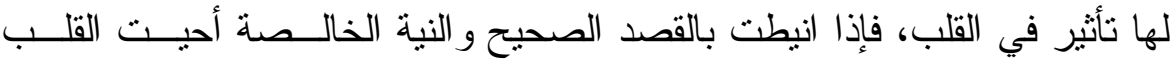

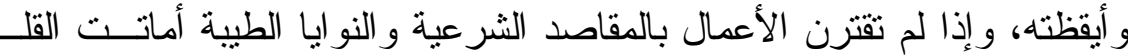

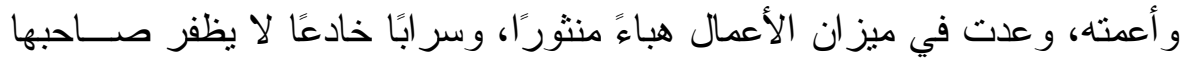

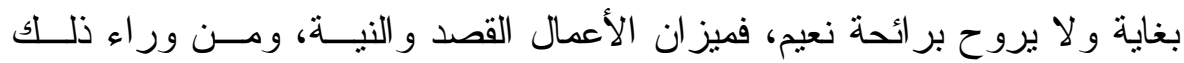

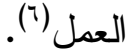

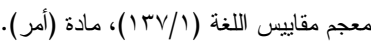

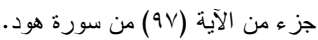

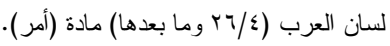

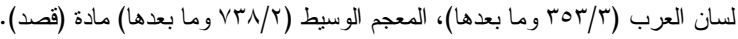

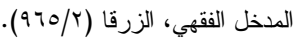

$$
\begin{aligned}
& \text { القو اعد الفقيية الكبرى اللسدلان (1) (1). }
\end{aligned}
$$




$$
\text { ومن أدلة على ذلك من الكتاب و السنة ما يلي: }
$$

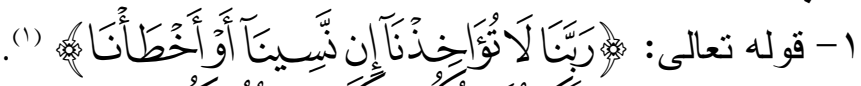

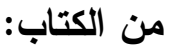

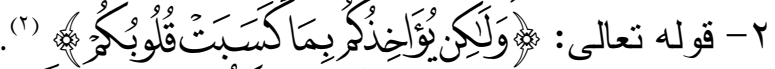

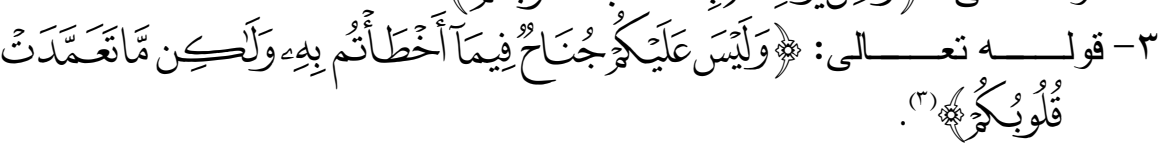

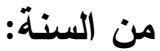

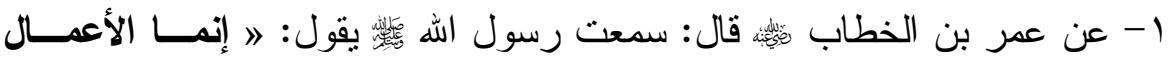

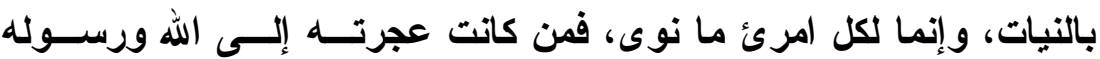

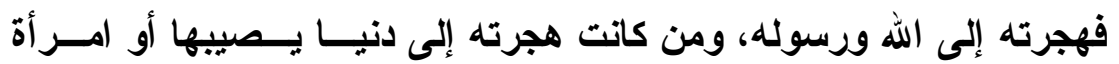

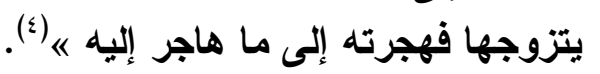

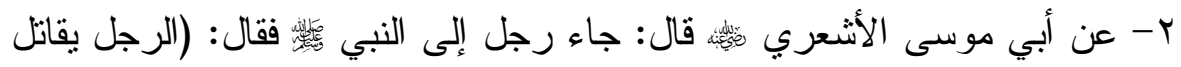

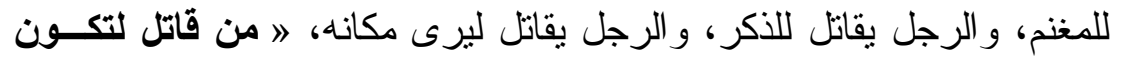

\section{كلمة الله هي العليا فهو في سبيل الله «)( (م).}

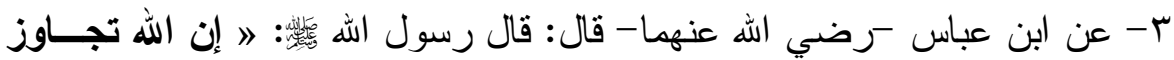

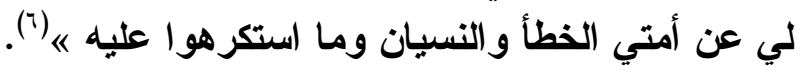

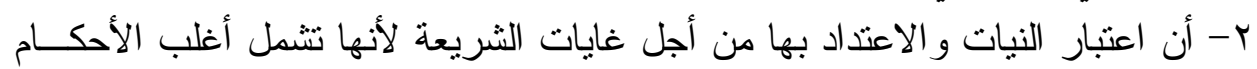

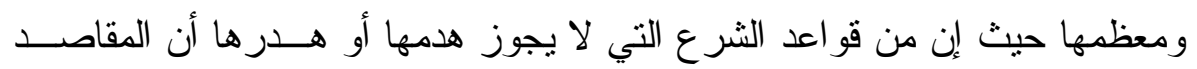

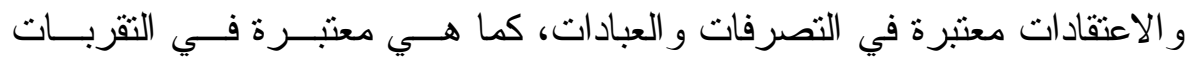

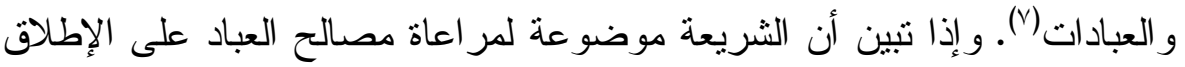

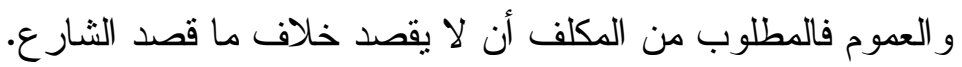

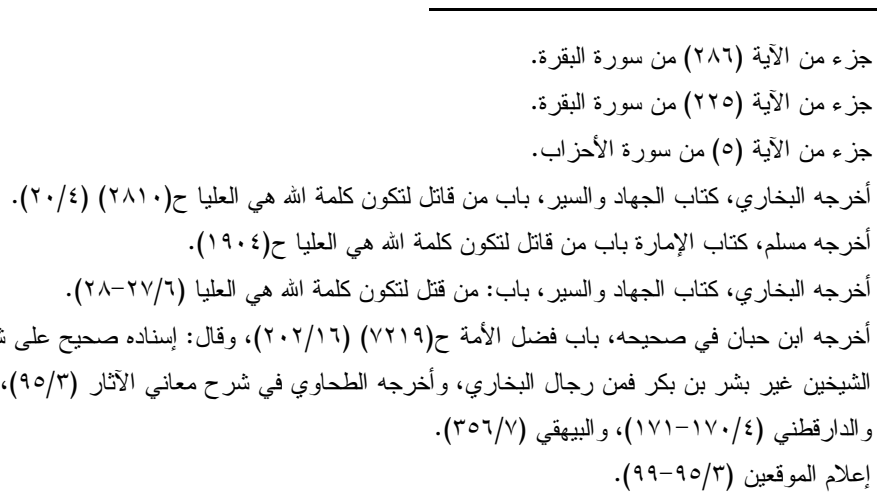

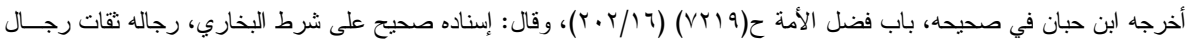

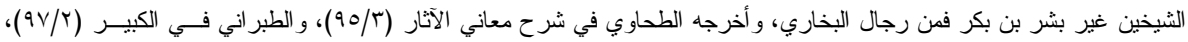

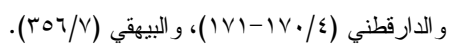


ب- نو اتر النقل عن العلماء في بيان منزلة هذه القاعدة و أنها معتبرة ومقصد من مقاصد

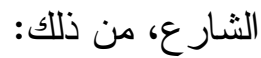

قال الثاطبي: "إن الأعمال بالنيات، و المقاصد معتبرة في التصرفات من العبــادات

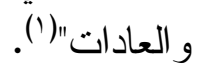
وقال أيضًا: "بكفيك منها أن المقاصد تفرق بين ما هو عادة وبين ما هـــو عبــادة،

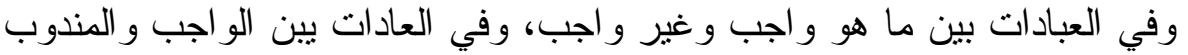
و المباح و المكروه و المحرم و الصحيح و الفاسد و غير ذللك من الأحكام" (؟).

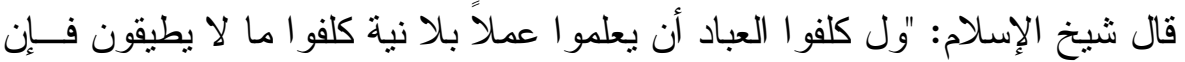

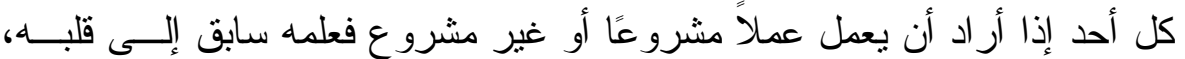
وذللك هو النية"(r).

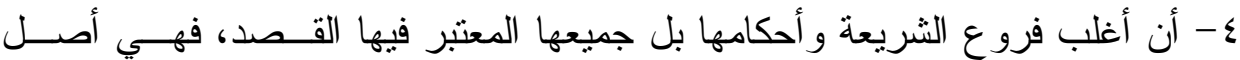

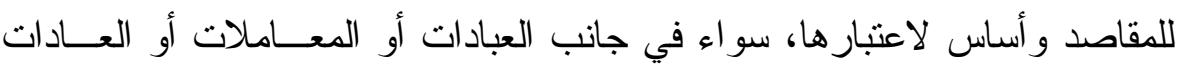
فمنى استحضرت النية في ذللك حصل للمسلم الثو اب على ما قاء باء به. 


\section{الخاتمة}

الحمد لله الذي بنعمته تتم الصالحات وتتو الى بمنّه البركات.

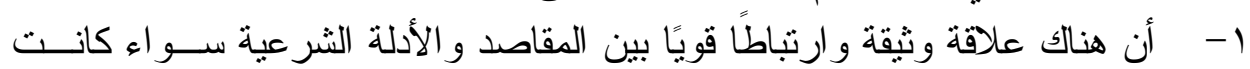

أدلة متفق عليها أو مختلف فيها.

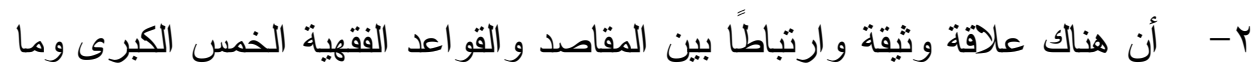

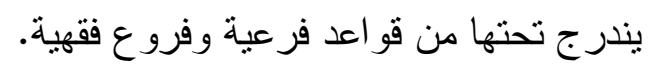

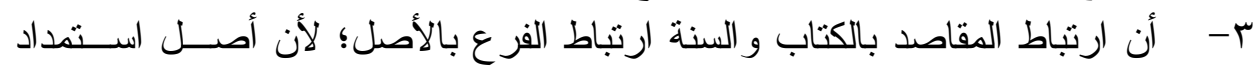

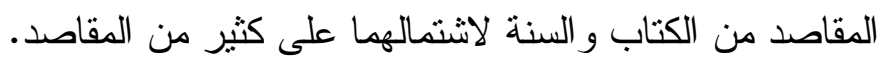

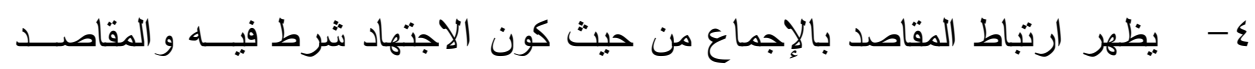
شرط في الاجتهاد.

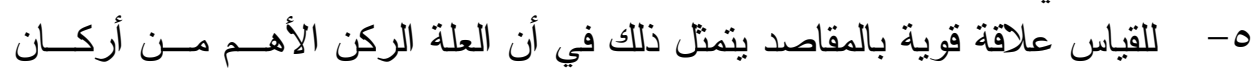

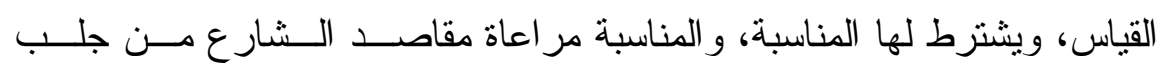
مصلحة أو در ع مفسدة. צ- - أن وجه ارتباط المقاصد بالمصالح المرسلة هو ملائمة تلك المــصالح لمقاصــــ الثار ع. - V أن علاقة المقاصد بالاستحسان بظهر من خلا كون الاستحسان عدول بالمسألة عن نظائر ها إلا لتحقيق مصالح أعظد بالاصن ودفع مفاسد.

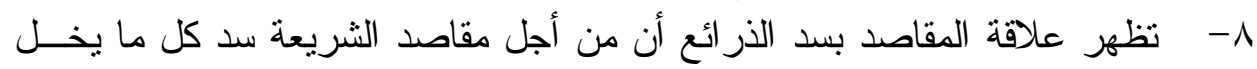
بالمحافظة على مقاصدها.

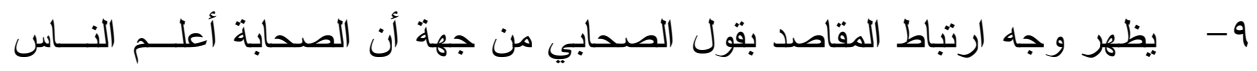

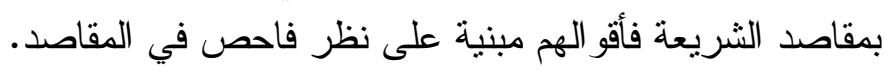

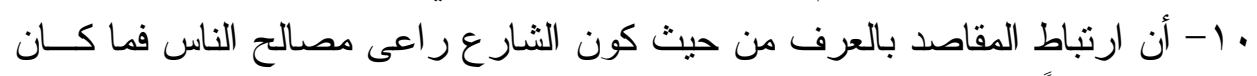

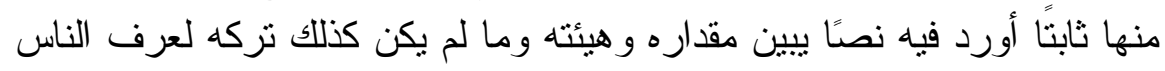
لكون المصلحة تتغير فيه بتغير الزمان و المكان و الحال. 1 ا أن ارتباط المقاصد بالثر ائع السابقة يظهر من خلال كون الثريعة لهان خهان خهائصها

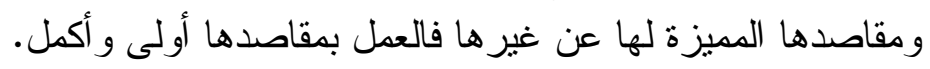
r ا أن علاقة المقاصد بالاستصحاب راجعة إلى علاقة الاستصحاب بالأدلة الأخرى.

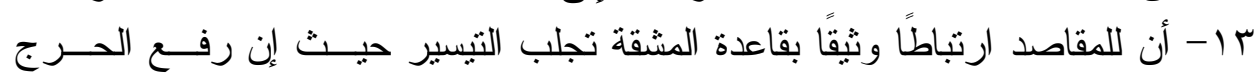

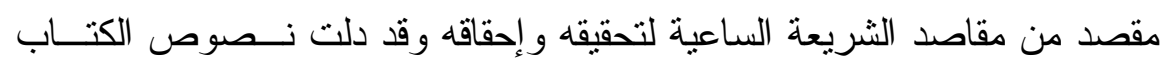
و السنة على إعماله. 
ع ا - أن إز الة الضرر مقصد الثار ع الحكيم وظهر من العلاقة القوية الر ابطــــة لقاعـــدة الضرر بز ال بالمقاصد.

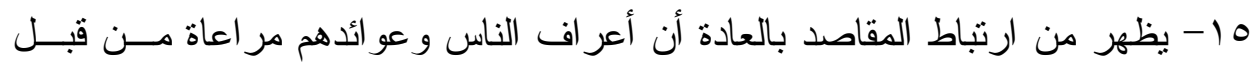

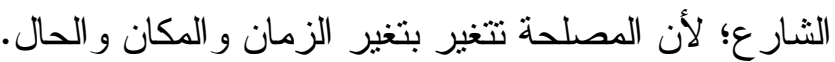

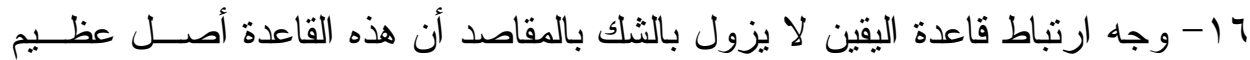

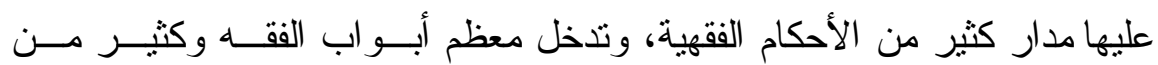

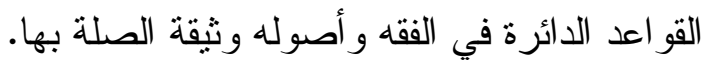

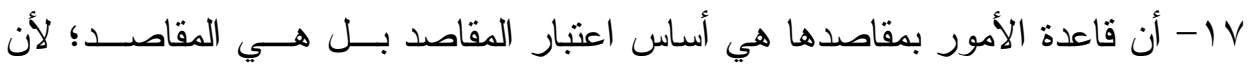

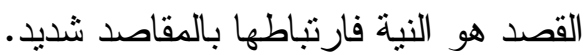




\section{فهرس المصادر والمر اجع}

1- الإبهاج في شرح المنهاج على منهاج الوصول إلى علم الأصول. للقاضي البيــضاوي،

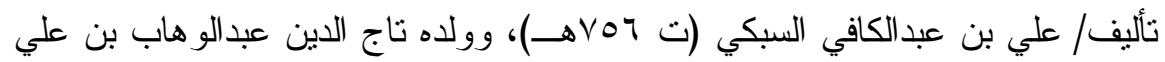

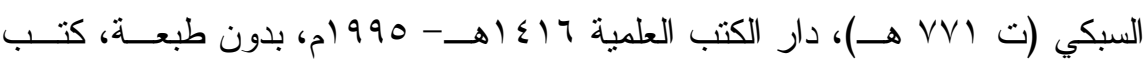

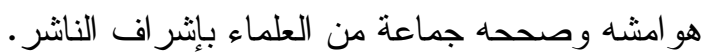

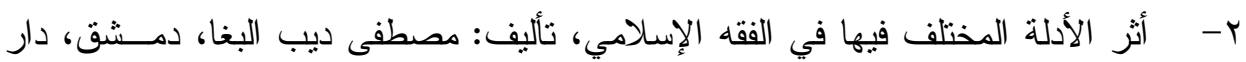
القلم ودار العلوم الإنسانية.

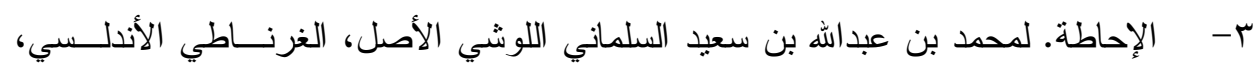

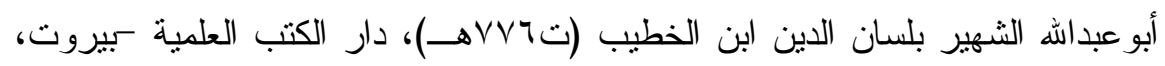

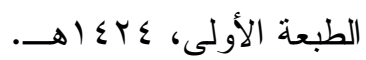

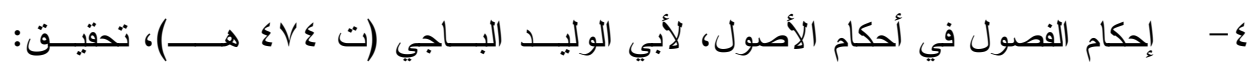

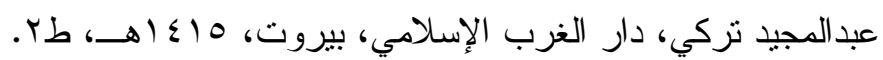

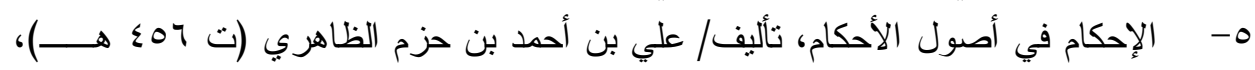

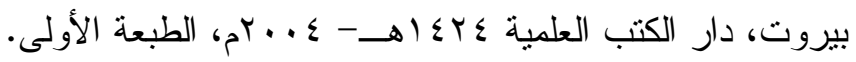

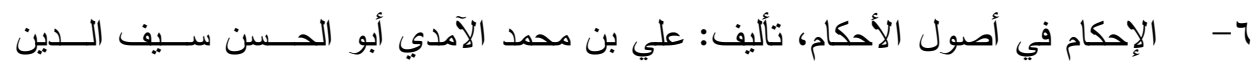

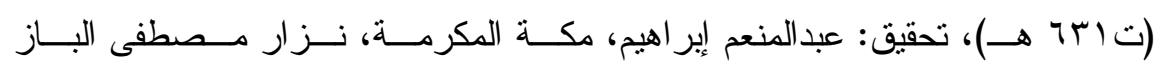

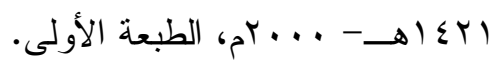

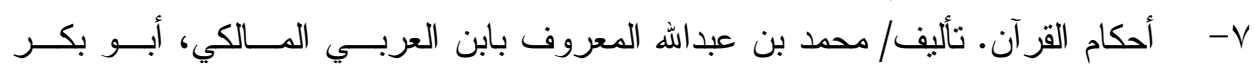

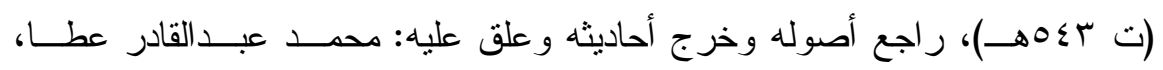

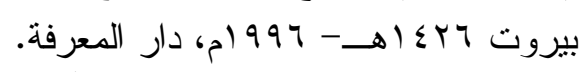

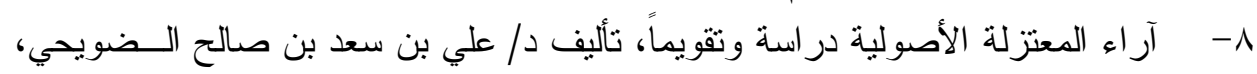

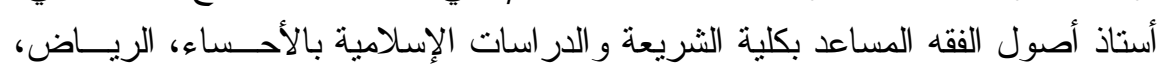

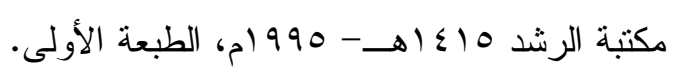

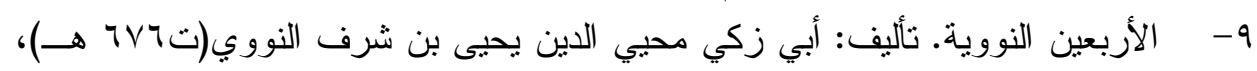

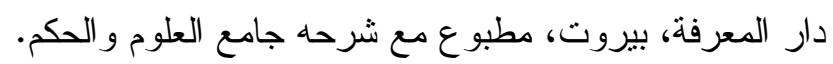

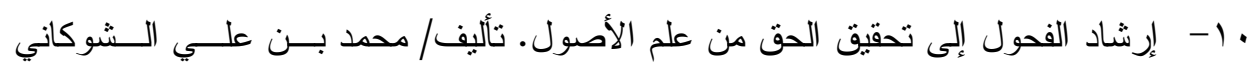

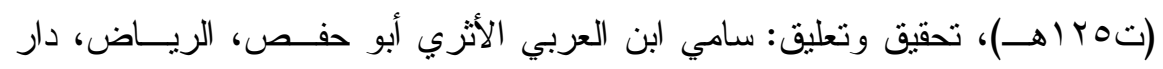
الفضبلة.

11- الاستقامة. لابن تيمية، مؤسسة قرطبة، مصر ، تحقيق: محمد رشاد سالم، طץ. 
Y ا - الأشباه و النظائر على مذهب أبي حنيفــة. لــزين الــدين بــن إبــر اهيم بــن نجــيم

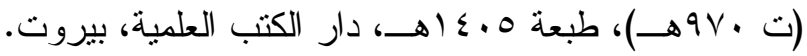

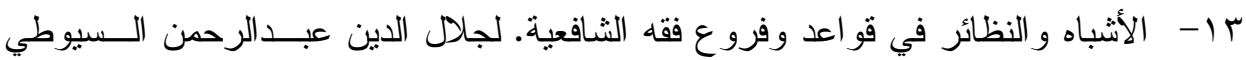

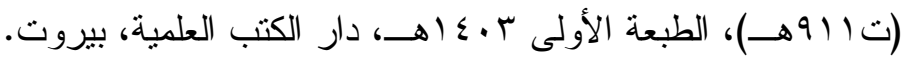

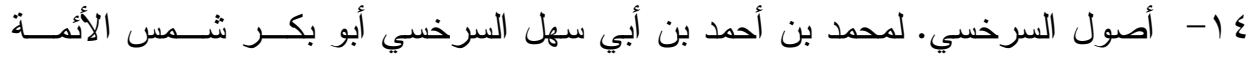

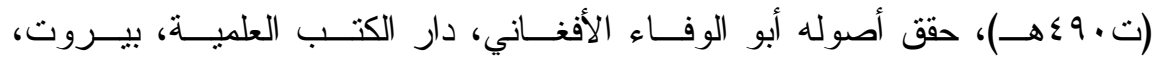

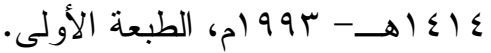

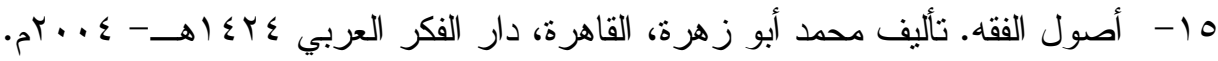

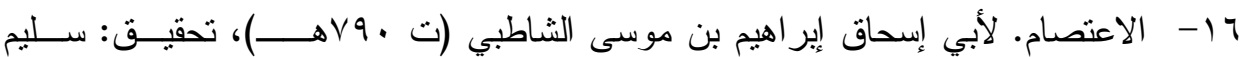

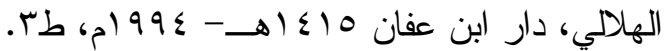

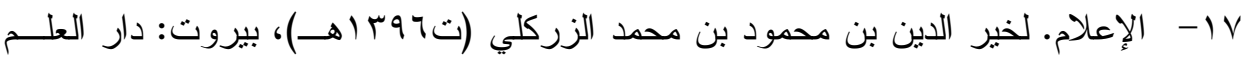

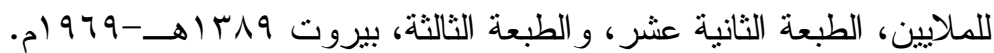

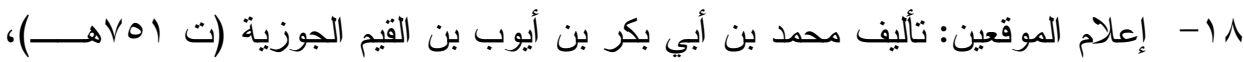

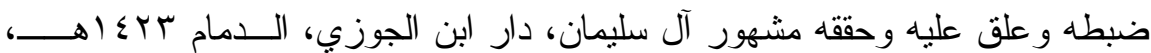

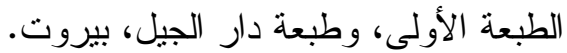

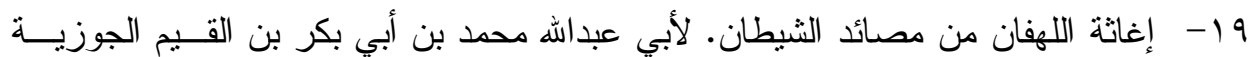

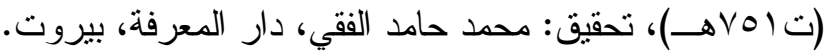

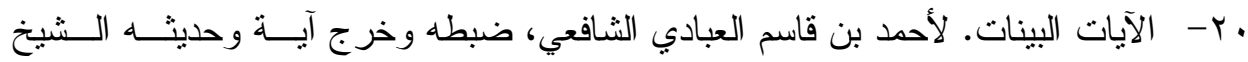

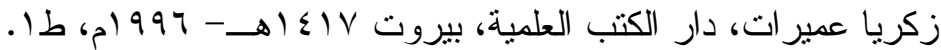

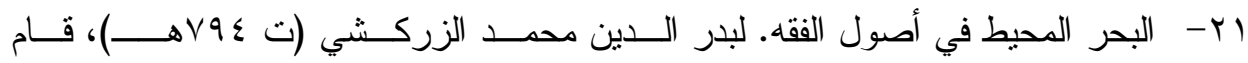

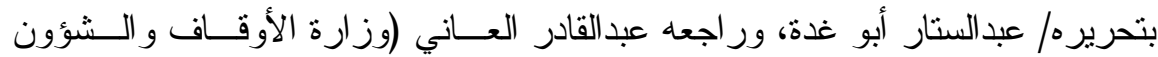

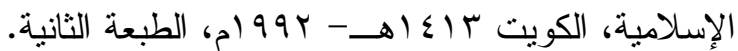

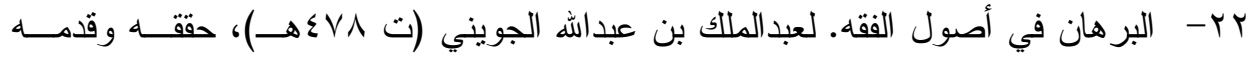

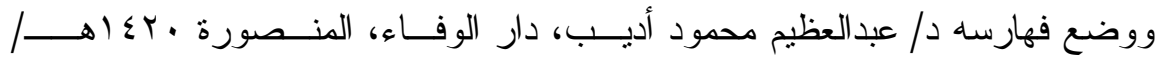

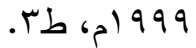

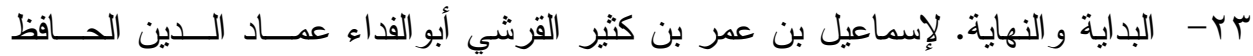

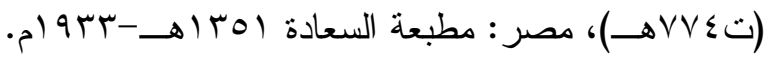

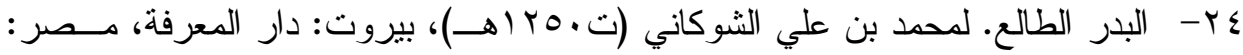

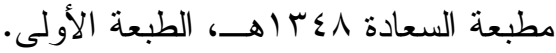




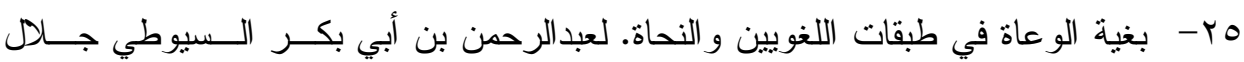

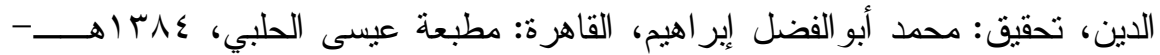
.

حب- بـ بائع الفو ائد. للإمام ابن القيم الجوزية، مطابع الفجالة الجديدة بمصر ، الطبعــة الثانيــة با به

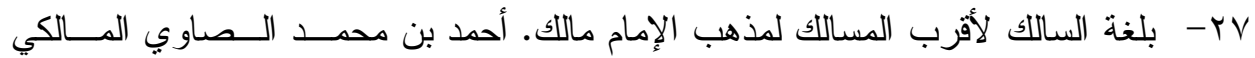

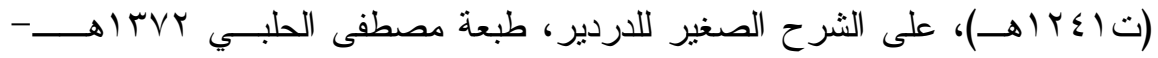
. 999

1 ץ- بيان المختصر مختصر ابن الحاجب. لمحمود بن عبدالرحمن بــن أحمــــ الأصــفهاني

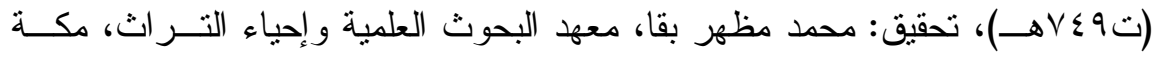

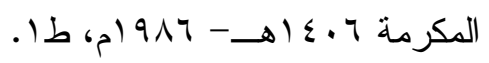

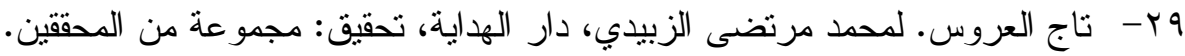

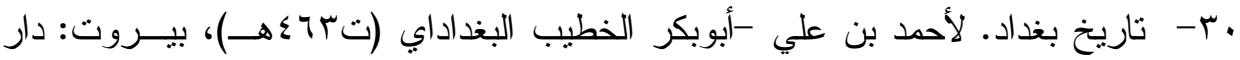

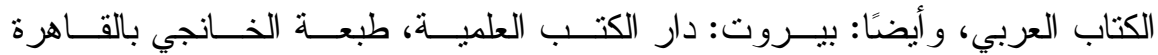
.م) $941-\rightarrow 1) 9$

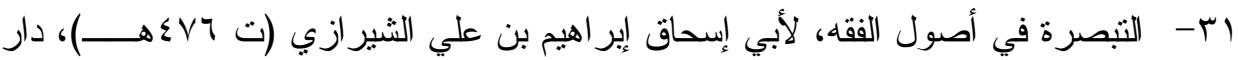
الفكر، دمشق، ·919 ام، الطبعة الأولى.

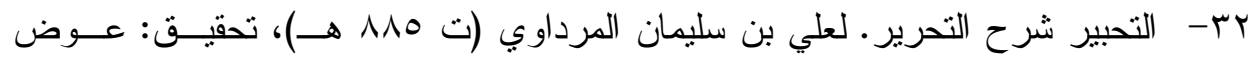

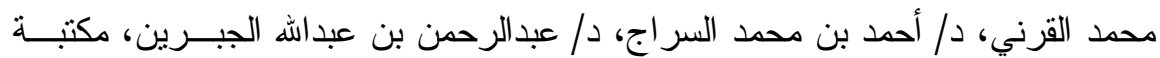

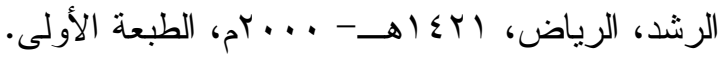

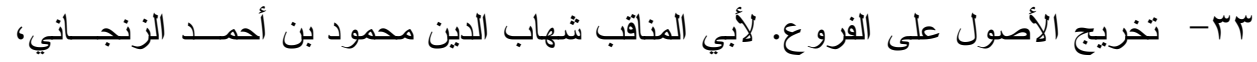

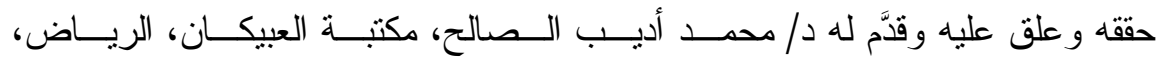

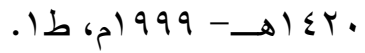

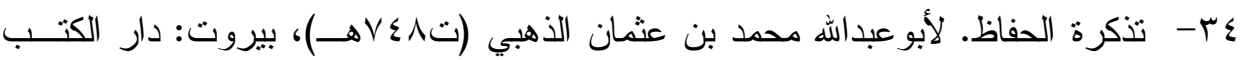

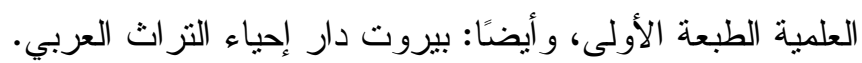

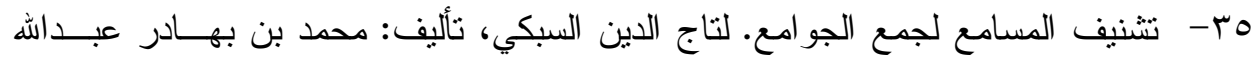

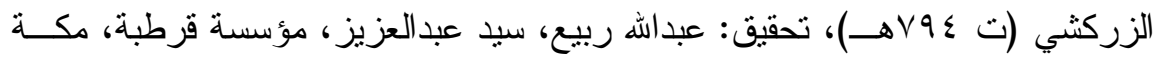
المكرمة 919 (الهـ، طس.

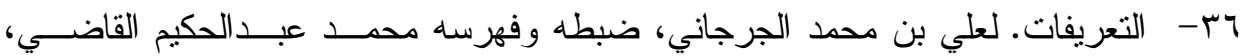

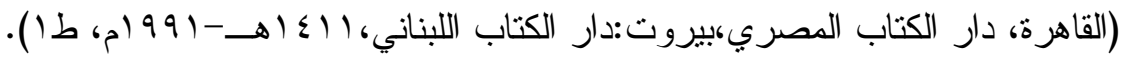




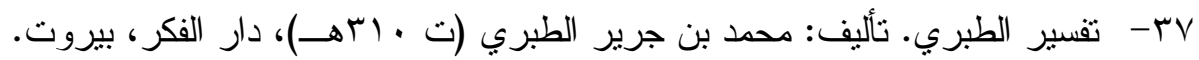

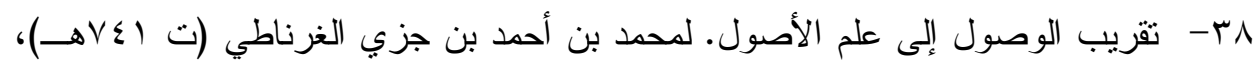

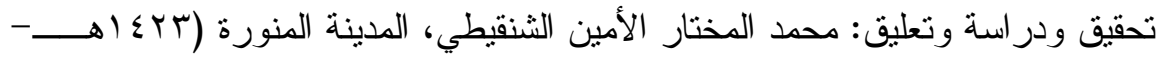

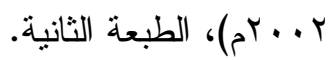

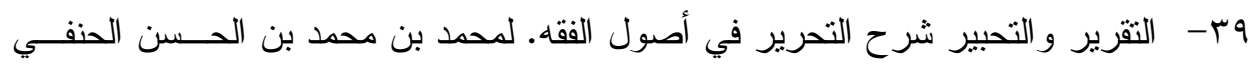

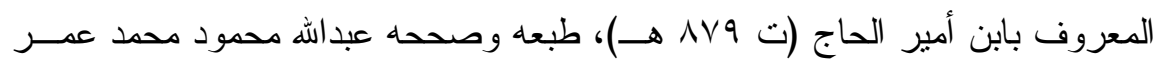

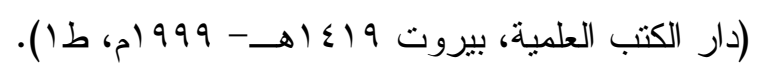

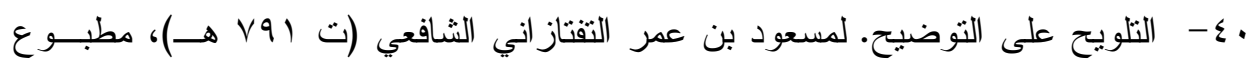

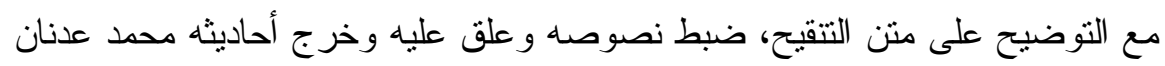

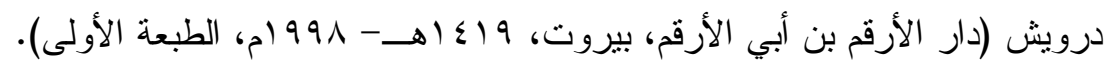

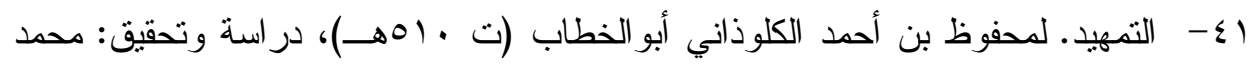

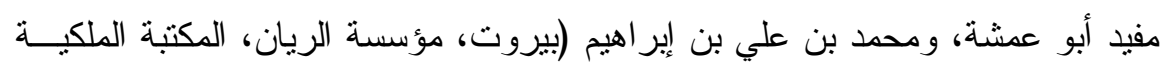

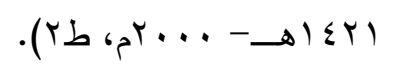

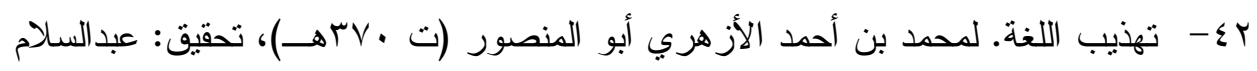
هارون، مر اجعة محمد علي النجار (مصر ، الدار المصرية).

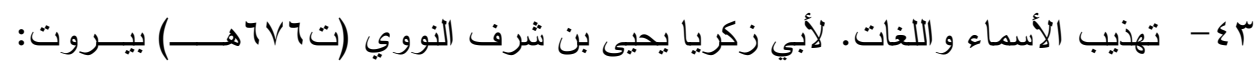

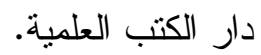

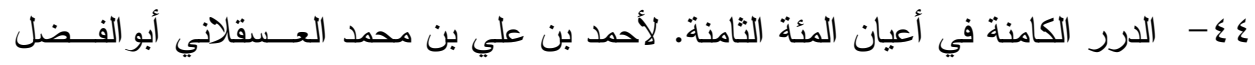

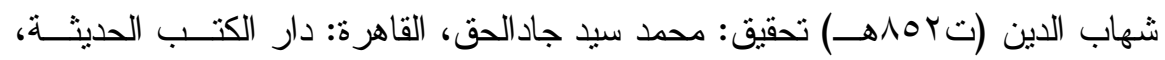

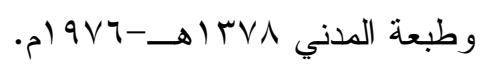

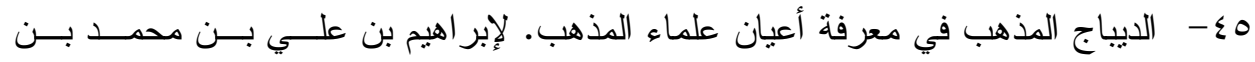

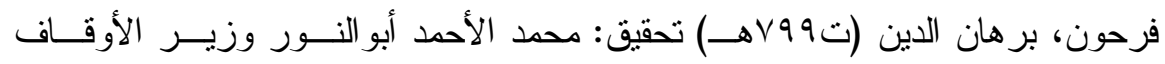

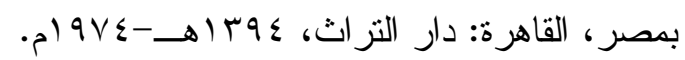

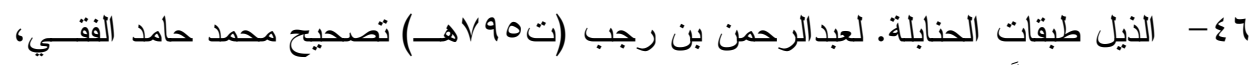

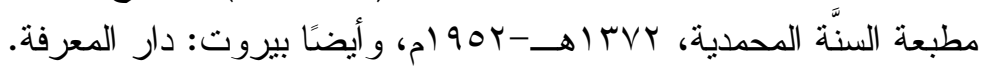

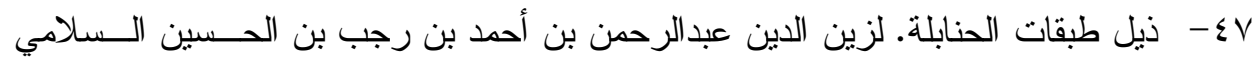

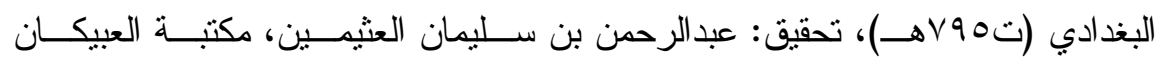

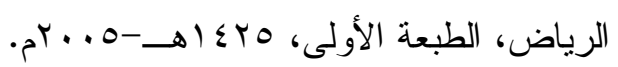

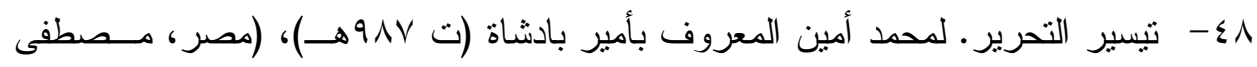

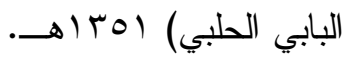




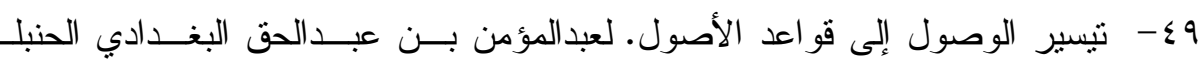

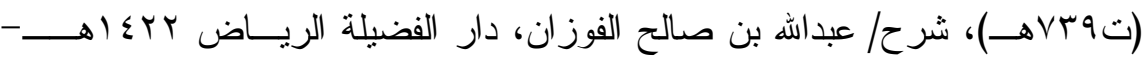

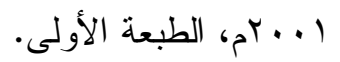

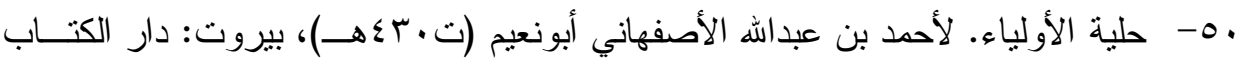

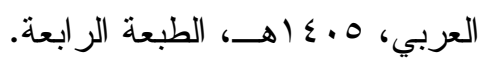

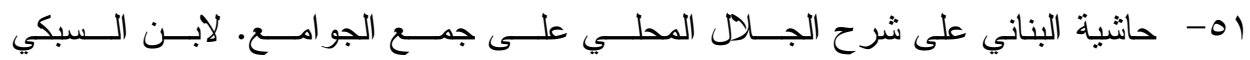

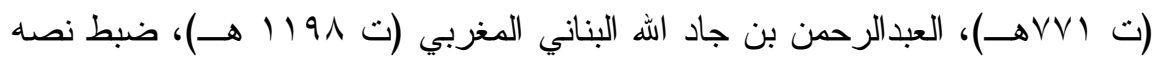

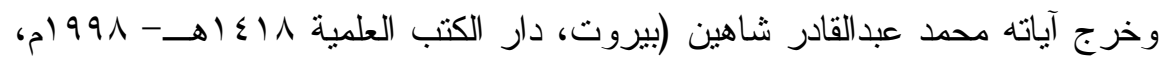
الطبعة الأولى.

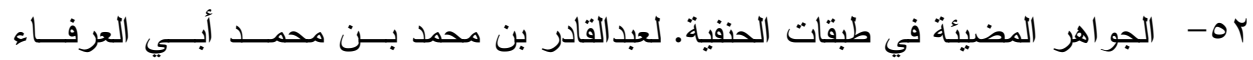

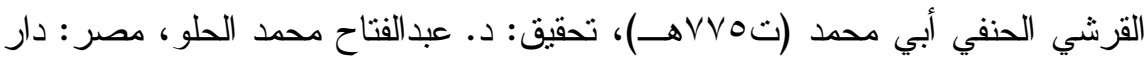

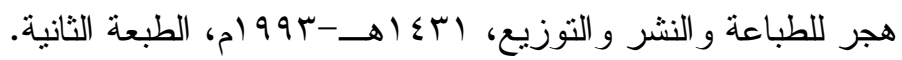

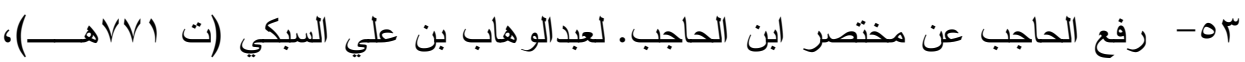

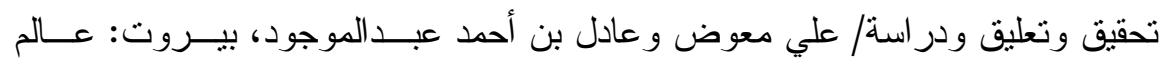

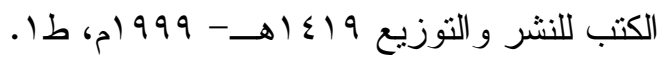

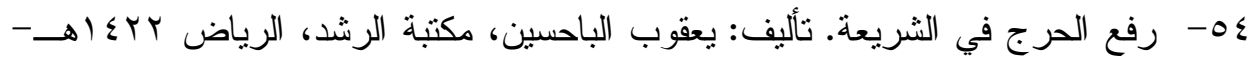

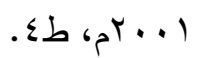

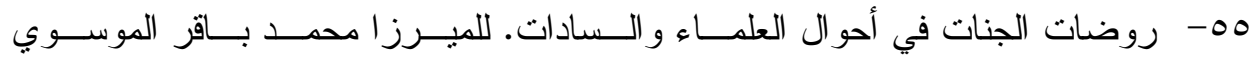

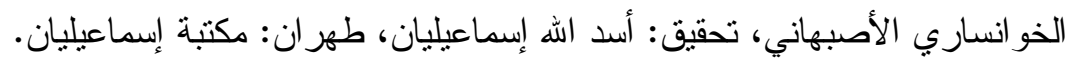

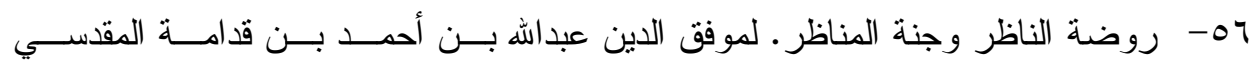

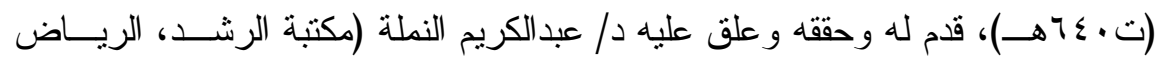

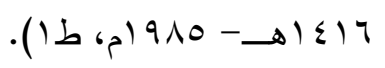

-OV

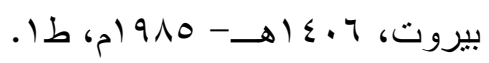

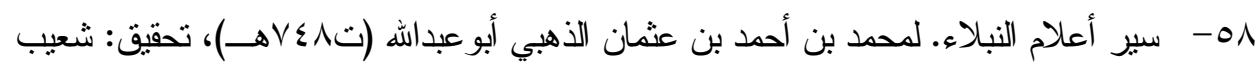

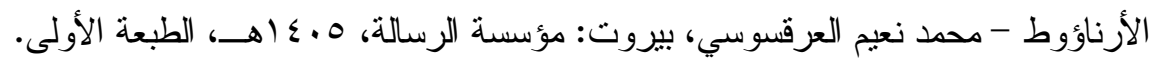

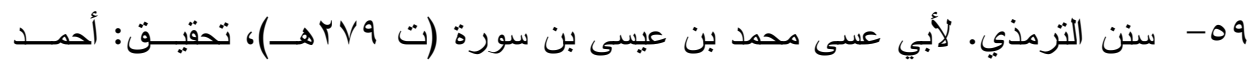

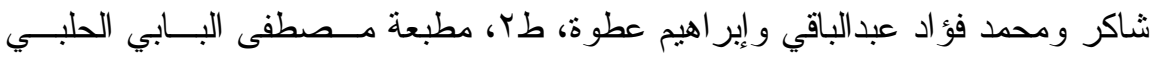

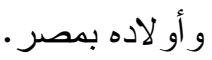




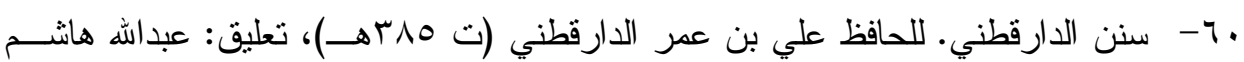
اليماني، طبعة دار المحاسن، القاهرة.

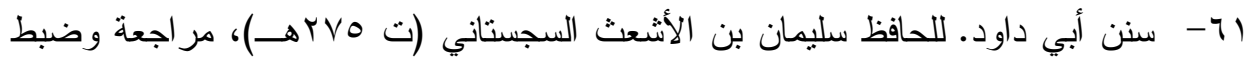

وتعليق: محمد محيي الدين عبدالحمبد، مكتبة الرياض الحديثة.

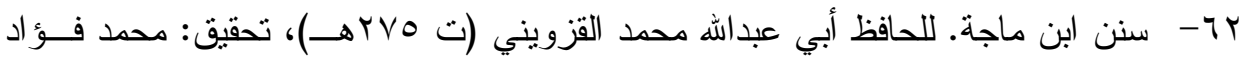
عبدالباقي، المكتبة العلمية، بيروت.

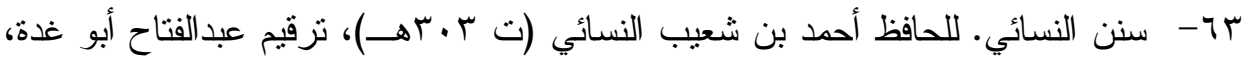

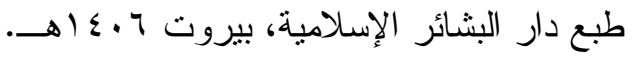

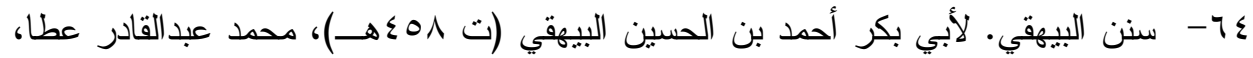

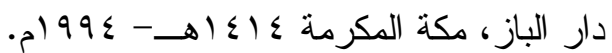

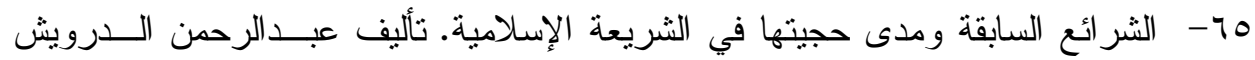

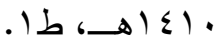
74- شذرات الذهب في أخبار من ذهب. لعبدالحي بن أحمد بن محمد المعروف بابن العماد

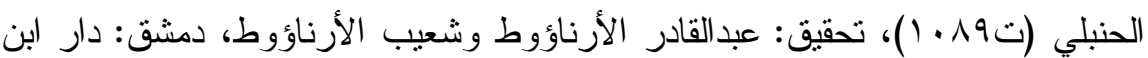

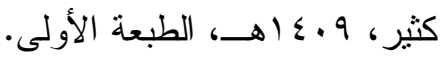

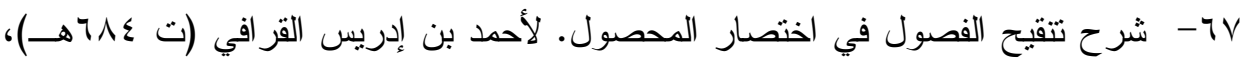

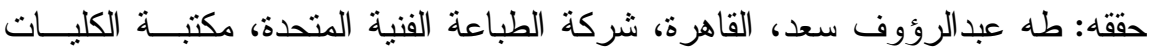

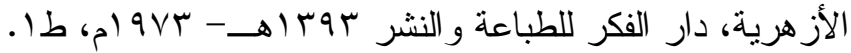
1

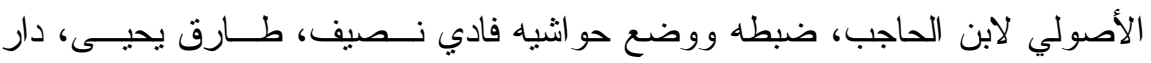

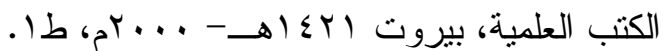

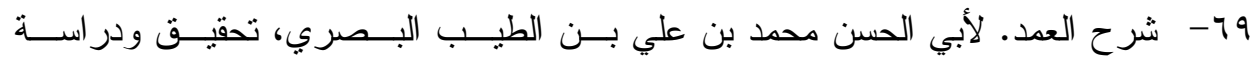

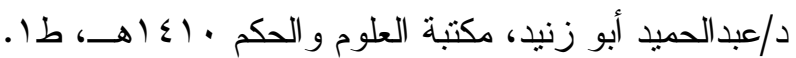

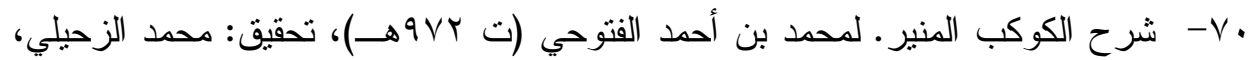

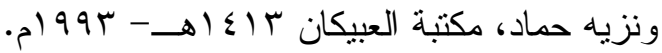

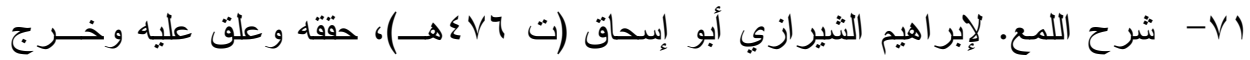

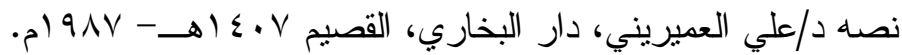


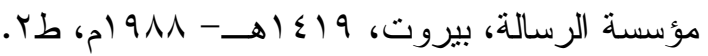




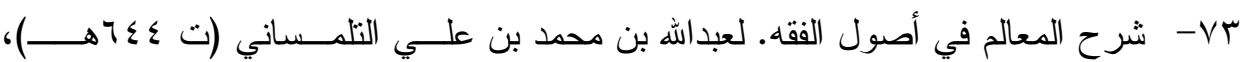

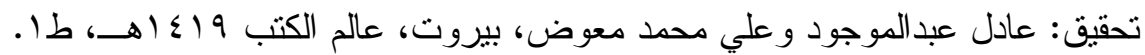

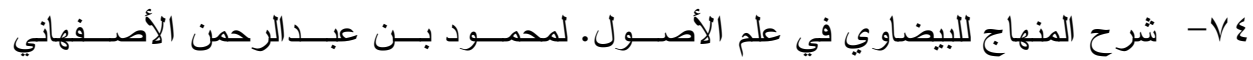

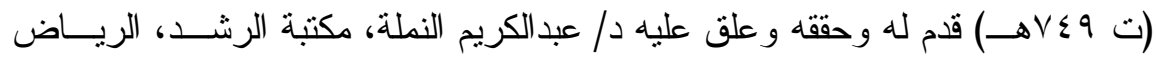

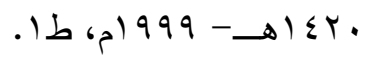

0 - شفاء الغليل. لأبو حامد محمد الغزالي (ت 00هـ)، تحقيق: د/ أحمد الكبيسي، مطبعة

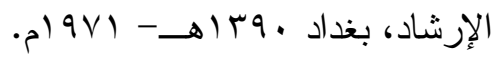

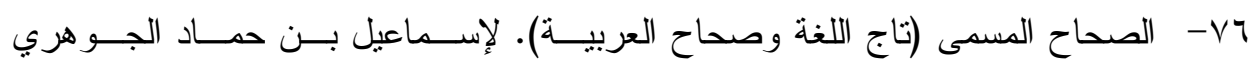

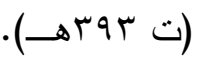

-VV

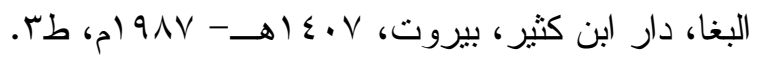

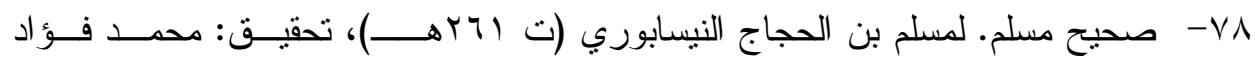

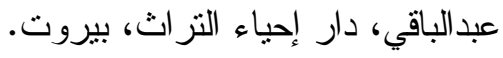


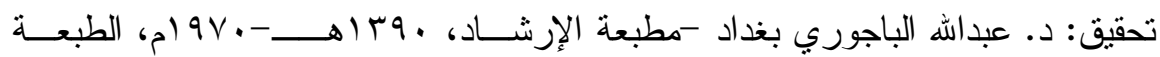

• ^- طبقات المعتزلة. لأحمد بن بحيى بن المرتضى، تحقيق: سوسنه ديفليد (بيروت -مكتبة

$$
\text { دار الحياة). }
$$

ا ا- ضوابط المصلحة في الثريعة الإسلامية. تأليف د/ محمد البوطي، مؤسسة الرســالة،

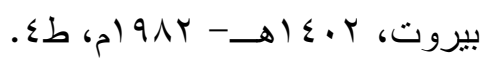

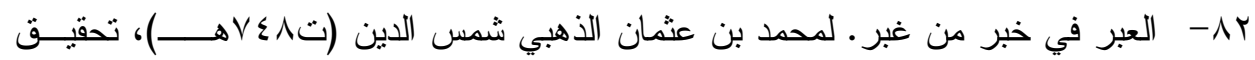

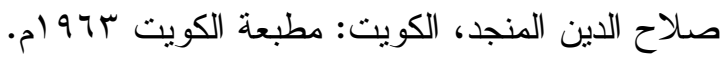

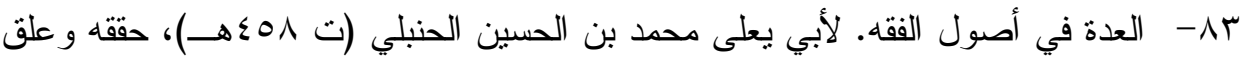

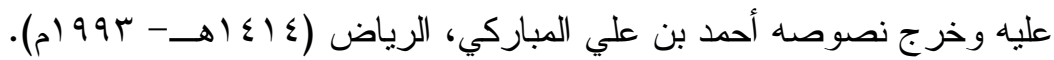

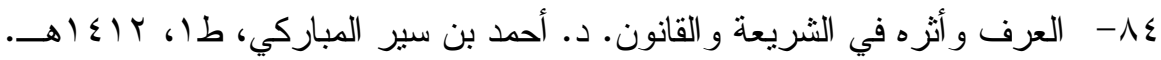

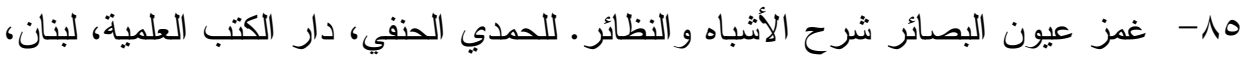
0. أهـ، طا.

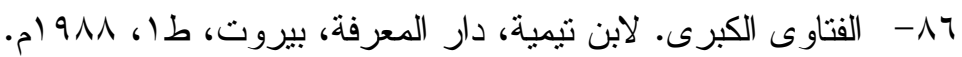

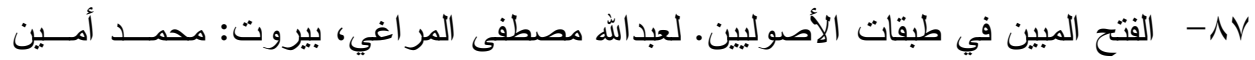

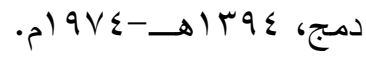




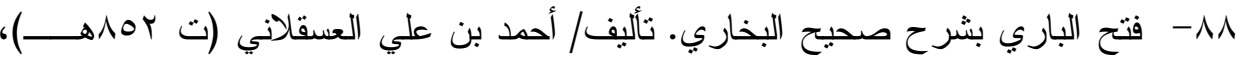

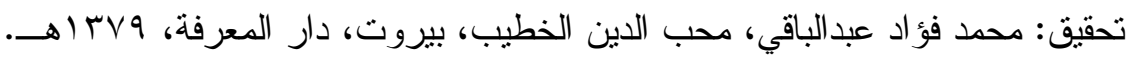

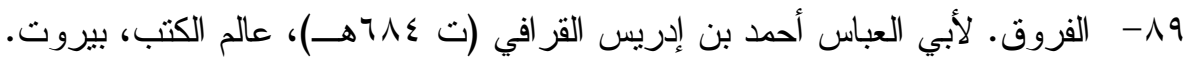

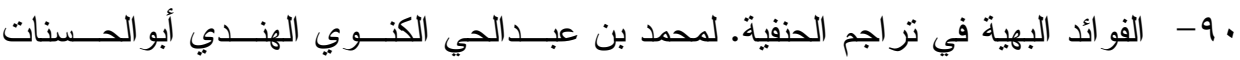

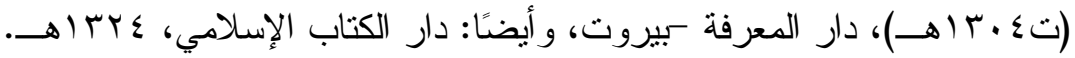

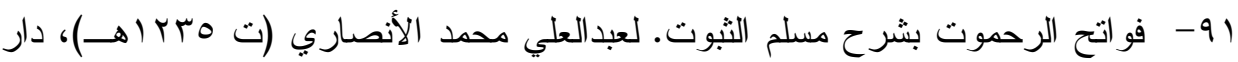

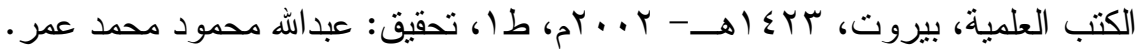

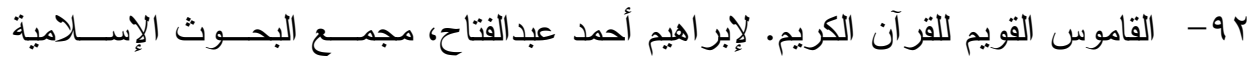
.

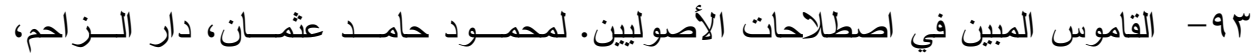

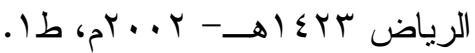

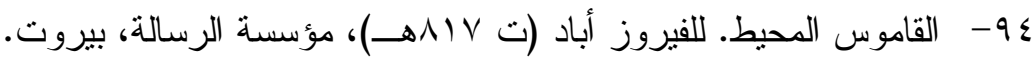

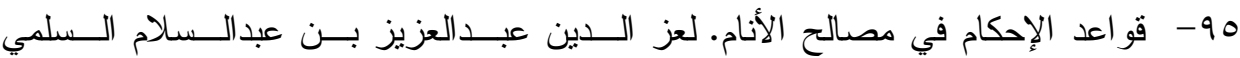

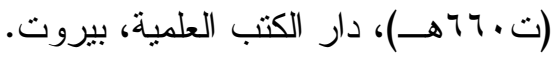

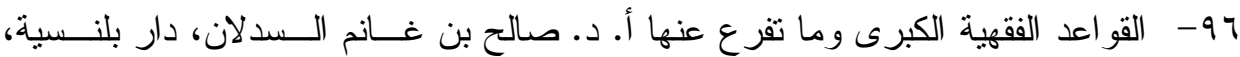

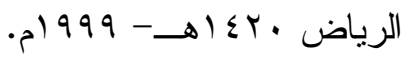

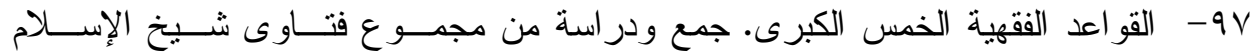

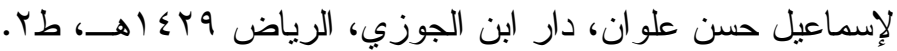

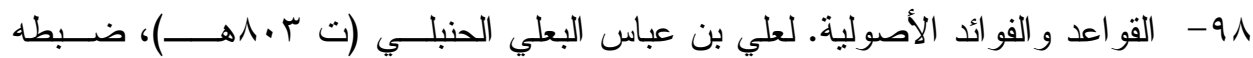

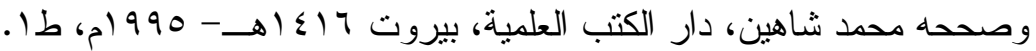

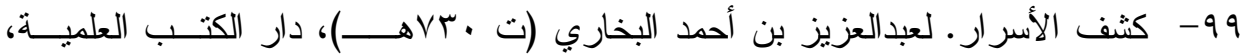

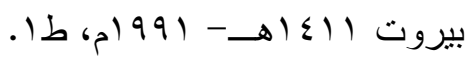

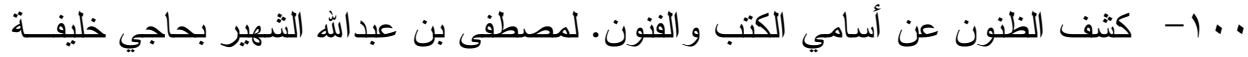

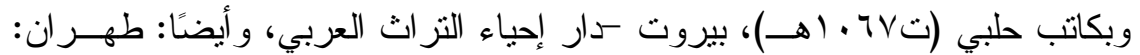
المكتبة الإسلامية، TVA اهــ، الطبعة الثالثة.

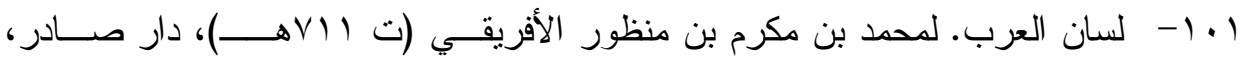

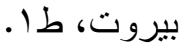
r • ا- مجموع الفتاوى. لثيخ الإسلام ابن تيمية. جمع عبدالرحمن بن قاسم النجدي و ابنــه، مكتبة النهضة الحديثة، مكة المكرمة. 


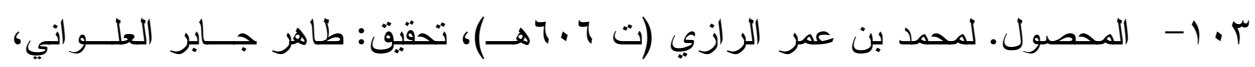

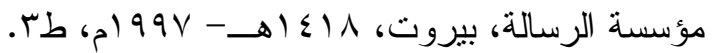

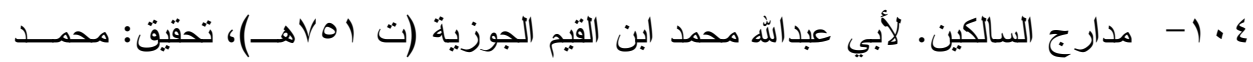

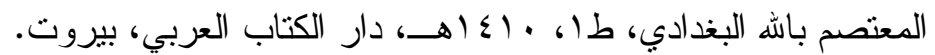

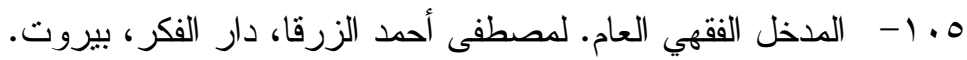

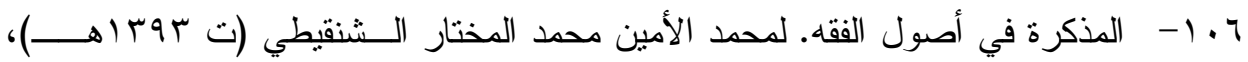

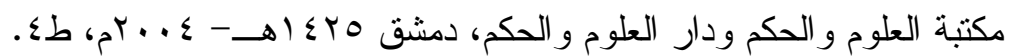

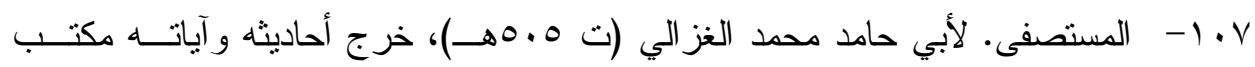

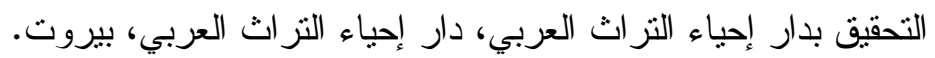

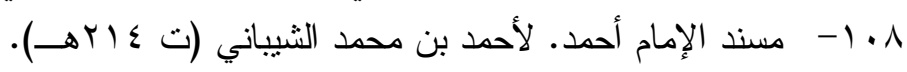

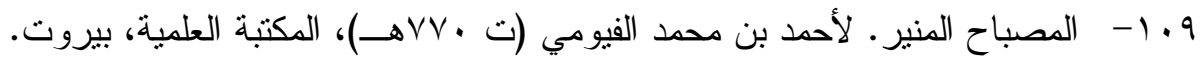

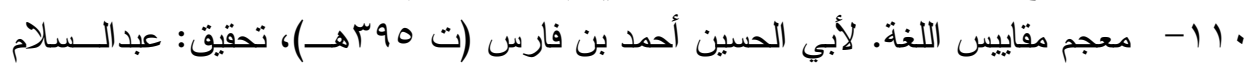

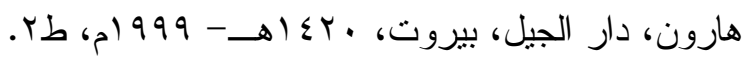

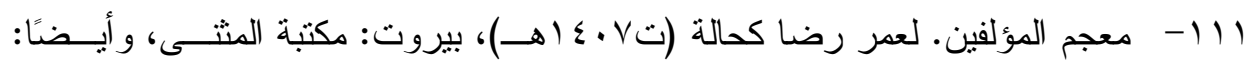

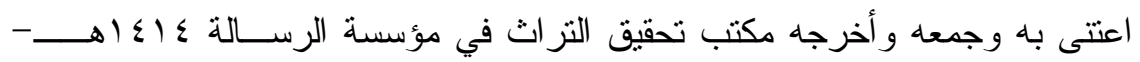

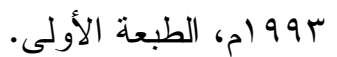

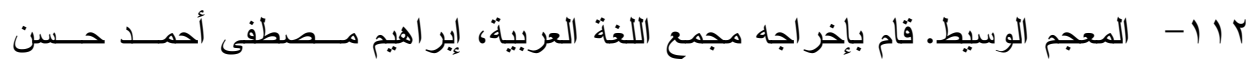

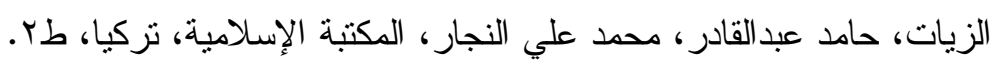

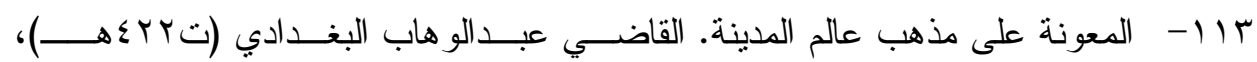

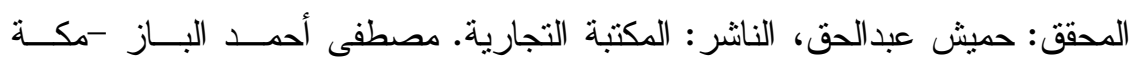

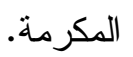

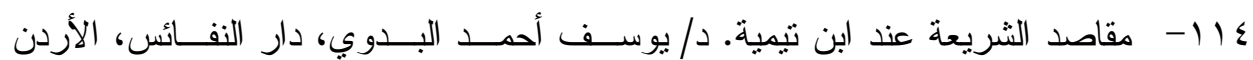

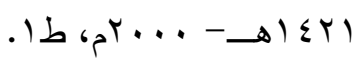
110

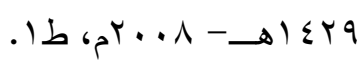
117

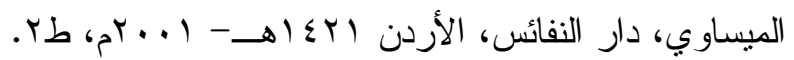

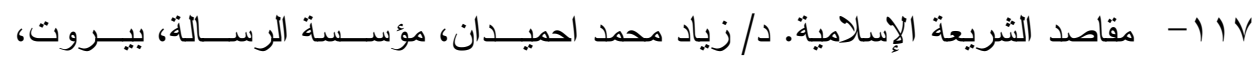
. ا 
111- مقاصد الثريعة الإسلامية وعلاقتها بالأدلة الثرعية. د/ محمد سـعد اليـوبي، دار

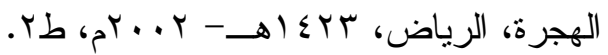

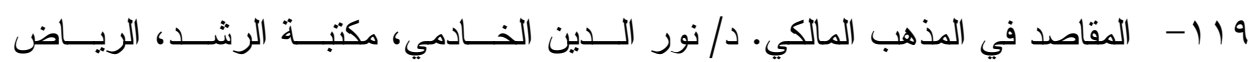

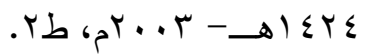
• r ا - المنهج لأحمد في تر اجم أصحاب أحمد. لعبدالرحمن بن محمد بن عبدالرحمن العليمي

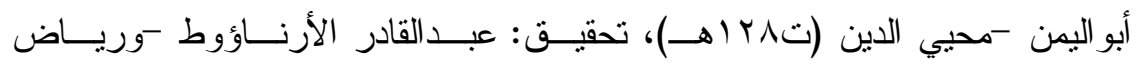

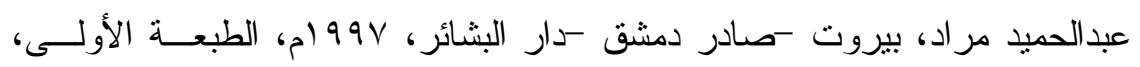

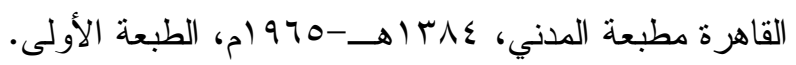

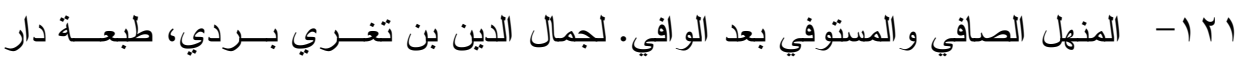

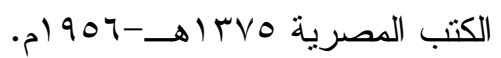

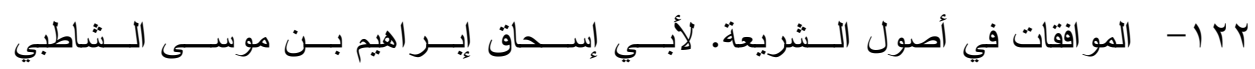

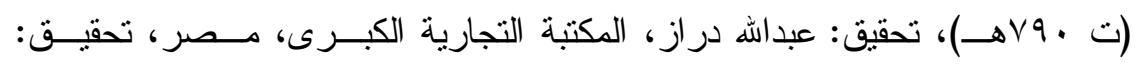

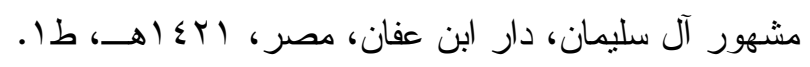

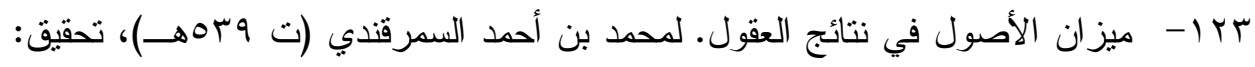

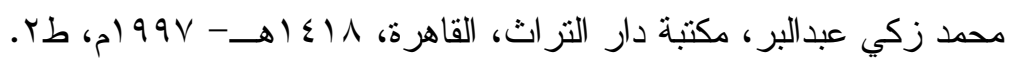

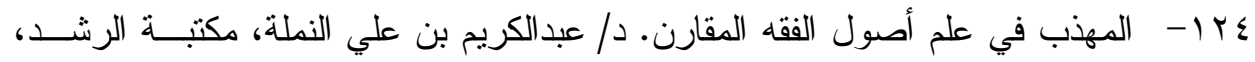

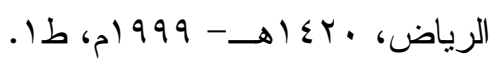

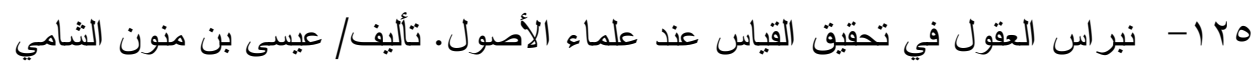

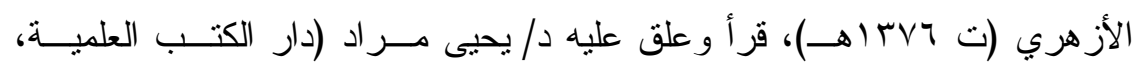

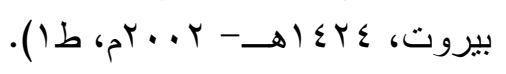

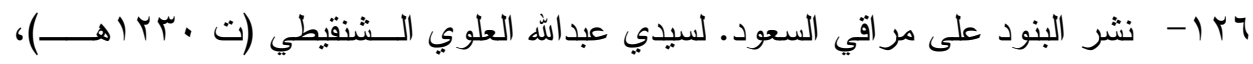

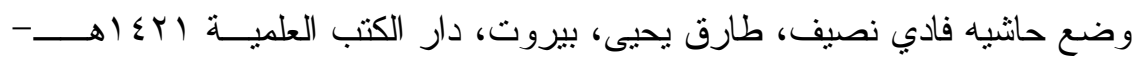
. M

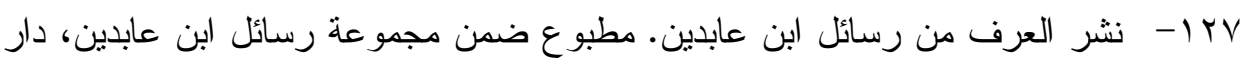
إحياء النزراث العربي، بيروت.

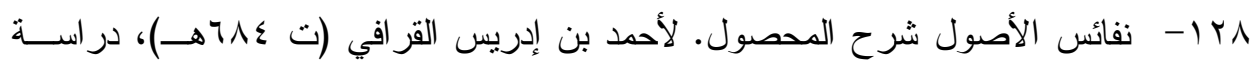

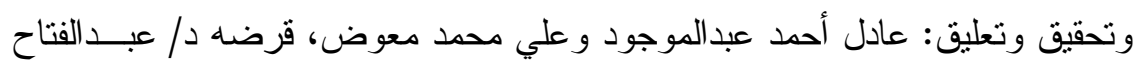

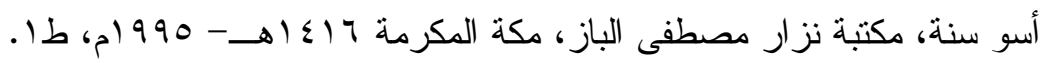

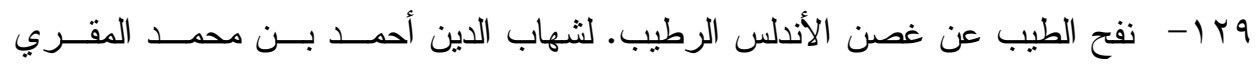

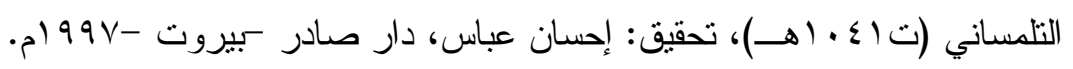




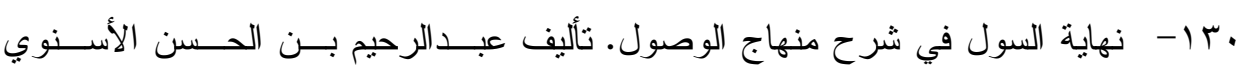

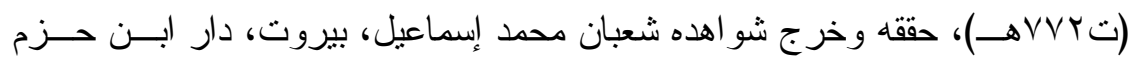

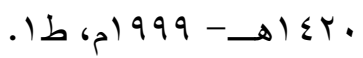

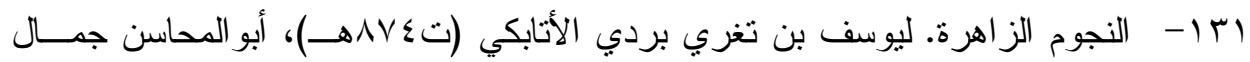

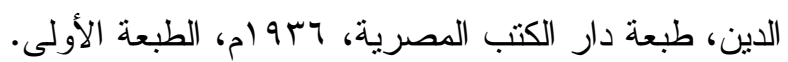

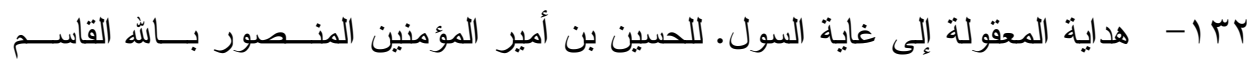
محمد، المكتبة الإسلامية.

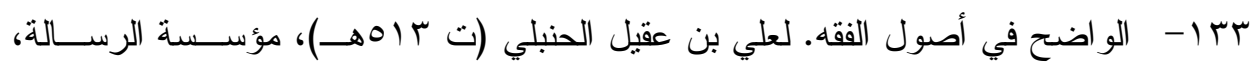

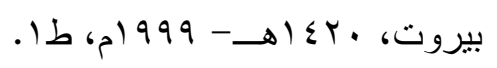

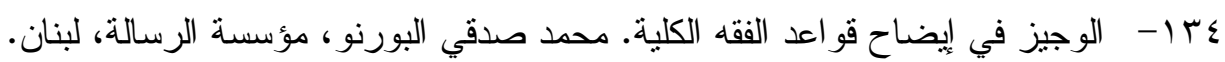

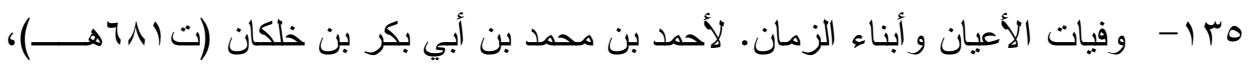

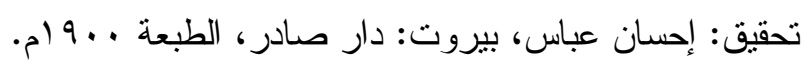

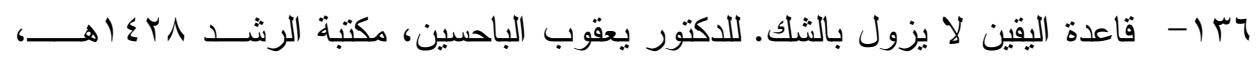
طr.

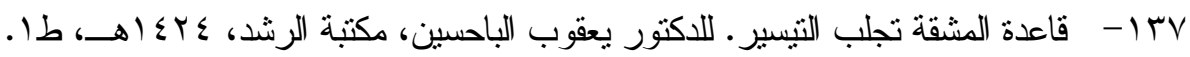

